\author{
by \\ Mohammad Ali Hossain \\ Bachelor of Science in Civil Engineering, 2000
}

Bangladesh University of Engineering \& Technology, Dhaka, Bangladesh.

\author{
A thesis \\ presented to Ryerson University \\ in partial fulfillment of the \\ requirements for the degree of \\ Master of Applied Science in the program of Civil Engineering
}

Toronto, Ontario, Canada, 2017

(C) Mohammad Ali Hossain, 2017 


\section{AUTHOR'S DECLARATION}

I hereby declare that I am the sole author of this thesis. This is a true copy of the thesis, including any required final revisions, as accepted by my examiners.

I authorize Ryerson University to lend this thesis to other institutions or individuals for the the purpose of scholarly research

I further authorize Ryerson University to reproduce this thesis by photocopying or by other means, in total or in part, at the request of other institutions or individuals for the purpose of scholarly research.

I understand that my thesis may be made electronically available to the public. 


\title{
CORROSION RESISTANCE OF HIGH-PERFORMANCE COMPOSITE BEAMS
}

\author{
Mohammad Ali Hossain \\ Master of Applied Science, 2017 \\ Department of Civil Engineering \\ Ryerson University, Toronto, Canada
}

\begin{abstract}
The research concentrated on the corrosion resistance of reinforced self-consolidating concrete (SCC), lightweight SCC (LWSCC), fiber reinforced LWSCC (FRLWSCC), Engineered cementitious composite (ECC) and composite (ECC-SCC/LWSCC) beams. The performance of corroded beams were analyzed based on current measurements, half-cell potential readings, crack pattern/width, rebar mass loss and diameter reduction from accelerated corrosion tests. Corroded and their companion uncorroded beams were tested to failure under four-point loading to evaluate load-deflection response, crack pattern, $1^{\text {st }}$ flexure/diagonal cracking load, failure load and failure modes. Composite beams with higher ECC layer thickness exhibited superior corrosion resistance than their lower thickness counterparts and full depth SCC or LWSCC counterparts as well as performance of beams with ECC wrap was better than those with layer. Overall, ECC beams can be a superior alternative of their conventional counterparts and ECC can be used as layer or wrapping in conventional/LWSCC beams to enhance corrosion resistance and structural performance.
\end{abstract}




\section{ACKNOWLEDGEMENT}

I am profoundly grateful to my supervisor Dr. Khandaker M. Anwar Hossain for his constant support and continued guidance. His extensive knowledge, together with his gentle way encouraged me to love and complete this research work. Without his endless support and follow up this thesis would not have been completed by the due date. I am also grateful to Mr. Nidal Jaalouk, Mr. Min Yao, Md. Saiful Hasib and Adam Culpeper for their assistance during casting and testing in the concrete and structure lab. I am deeply forever obligated to my parents and siblings for their love, support and encouragement throughout my entire life. Above all, my sincere gratitude and love to my wife Tasleema Begum for her continuous love and caring. She was always besides me supporting and cheering me to complete this work. 


\section{DEDICATION}

To my parents

Who sacrificed their lives for my greatest success. 


\section{TABLE OF CONTENTS}

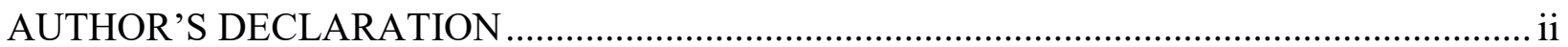

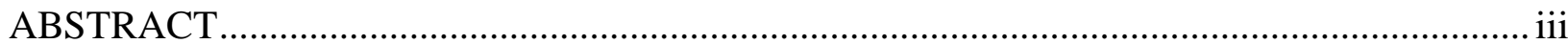

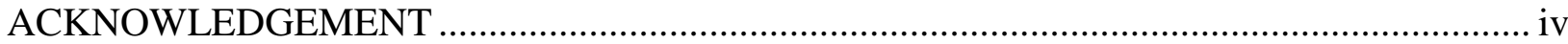

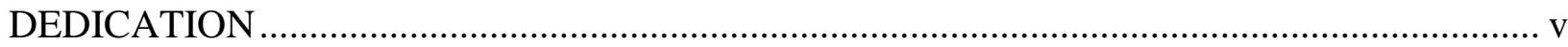

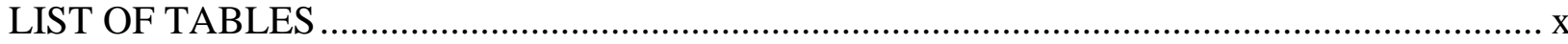

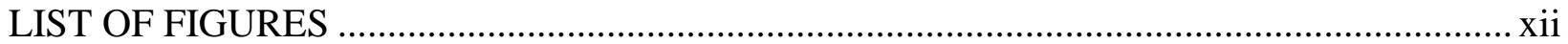

LIST OF SYMBOLS AND ABBREVIATIONS .............................................................

CHAPTER 1 : INTRODUCTION ............................................................................... 1

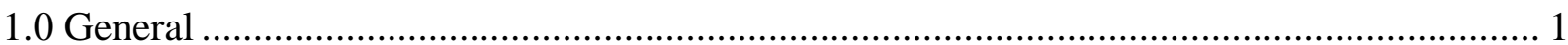

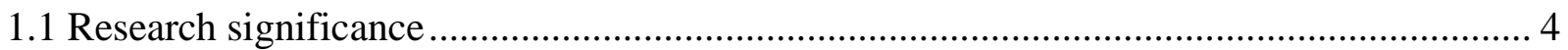

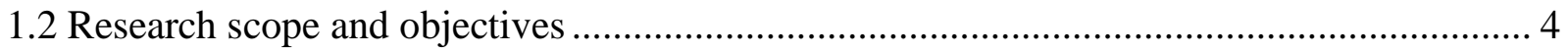

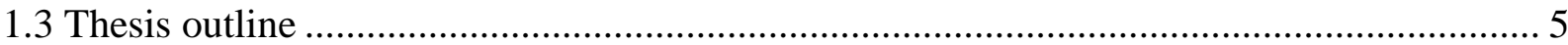

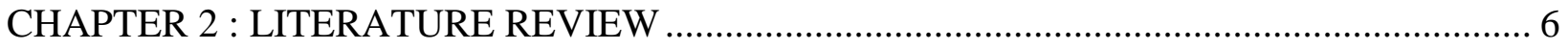

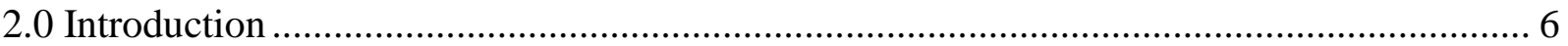

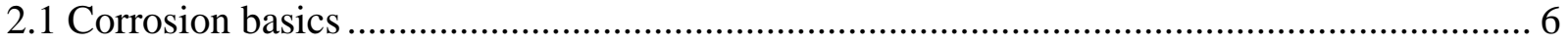

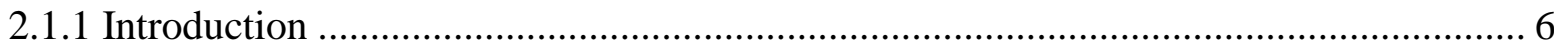

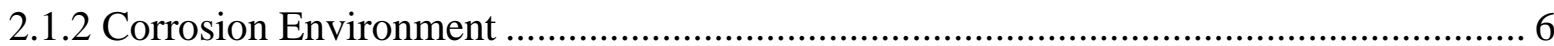

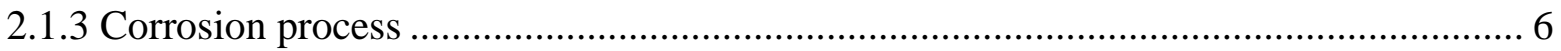

2.1.4 Resistivity of Concrete and the passive layer ................................................ 7

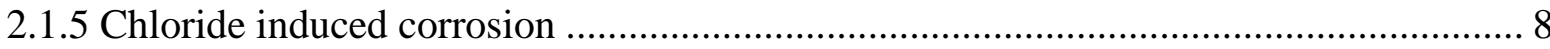

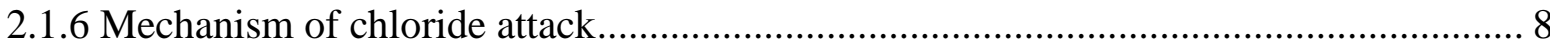

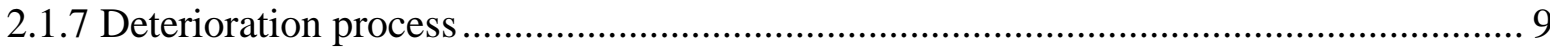

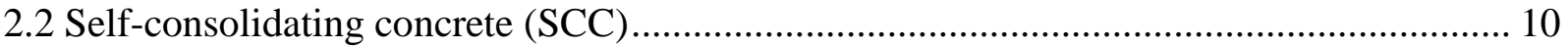

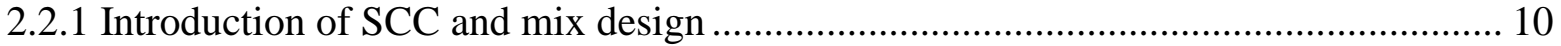


2.2.2 Application of SCC and Typical mix design ................................................ 12

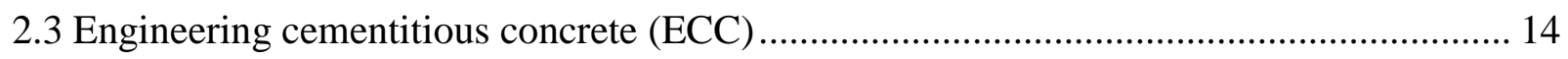

2.3.1 Introduction and Mix design......................................................................... 14

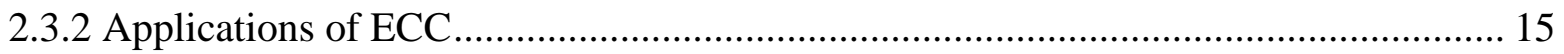

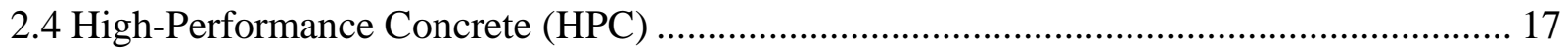

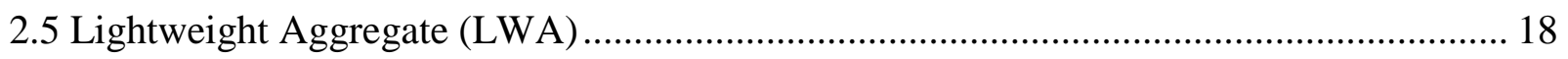

2.5.1 Introduction of Lightweight Aggregate ........................................................ 18

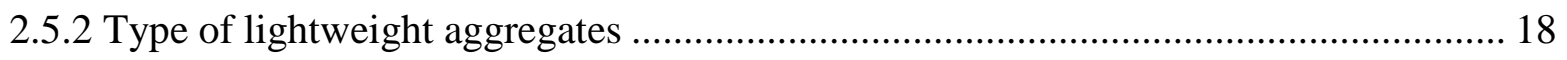

2.5.3 Physical Properties of lightweight aggregates .......................................................... 19

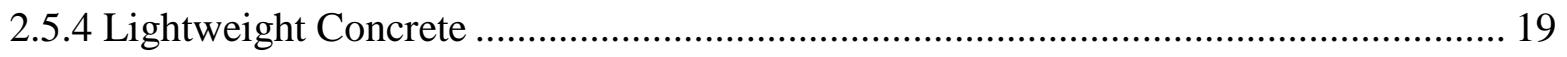

2.6 Lightweight Self- Consolidating Concrete (LWSCC) ............................................. 20

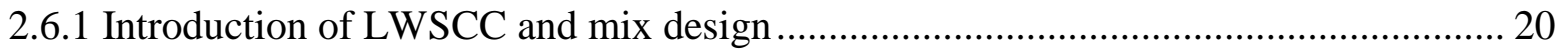

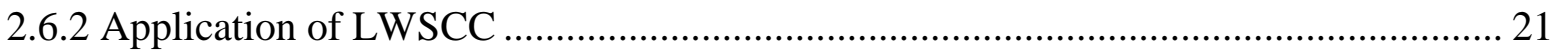

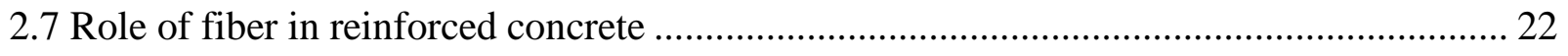

2.7.1 Polyvinyl alcohol (PVA) fiber............................................................................. 22

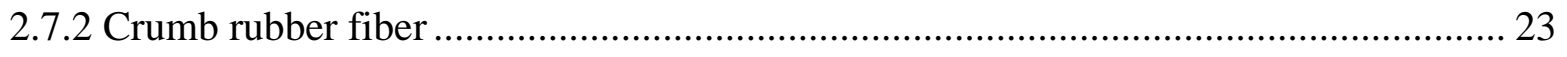

2.7.3 High Density poly ethylene (HDPE) fiber ................................................... 24

2.8 Related research on corrosion study of reinforce concrete beams .............................. 24

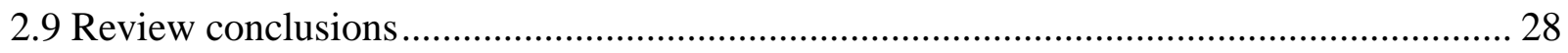

CHAPTER 3 : EXPERIMENTAL PROGRAM............................................................. 30

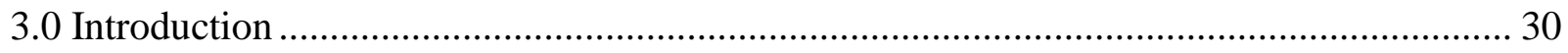

3.1 Beam geometry, beam types and reinforcement configurations ….............................. 30

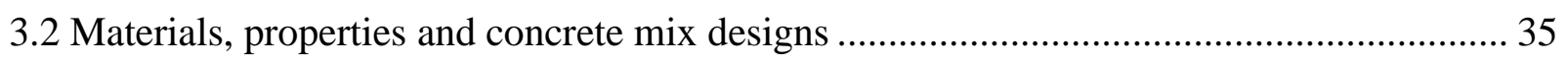

3.2.1 Concrete materials, properties and mix design............................................... 35

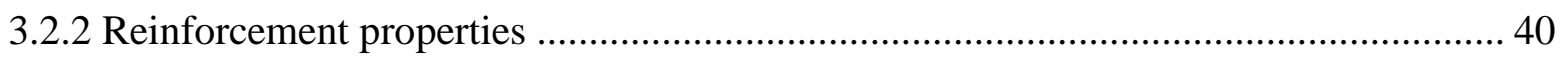


3.3 Beam specimen fabrication, casting and curing.

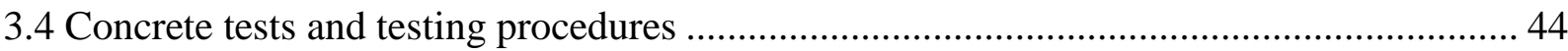

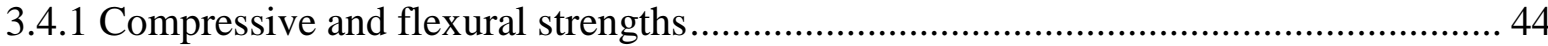

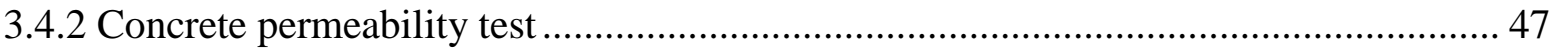

3.5 Experimental setup, instrumentation and testing ................................................... 48

3.5.1 Accelerated corrosion testing procedure ........................................................ 48

3.5.2 Accelerated corrosion testing- current-time response, theoretical rebar mass loss and

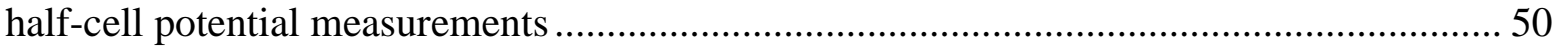

3.5.3 Accelerated corrosion testing- Cracks pattern and spalling measure ........................52

3.5.4 Accelerated corrosion testing- measurement of mass loss and bar diameter after

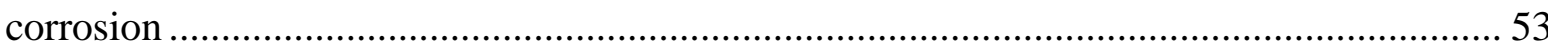

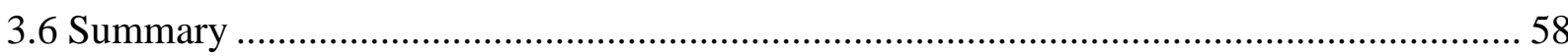

CHAPTER 4 : EXPERIMENTAL RESULTS AND DISCUSSIONs .................................... 59

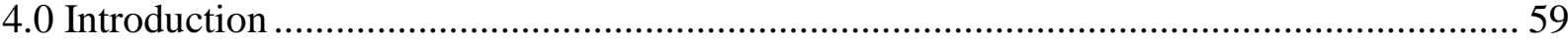

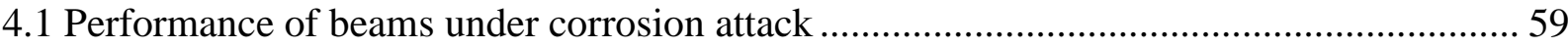

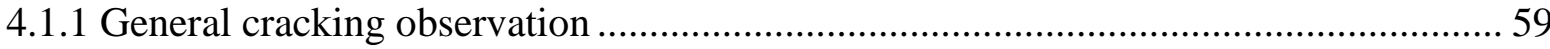

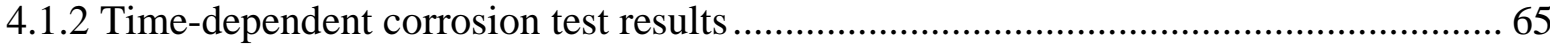

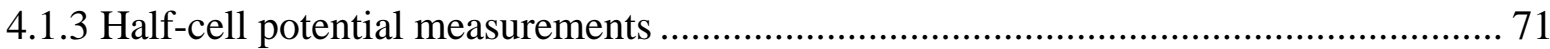

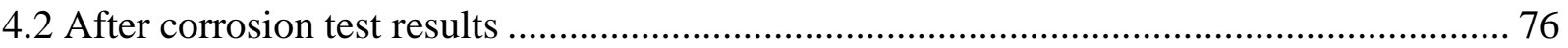

4.2.1 Chloride ion permeability, mass loss, and bar diameter reduction of group A beams 76

4.2.2 Chloride ion permeability, mass loss, and bar diameter reduction of group B beams . 77

4.2.3 Chloride ion permeability, mass loss, and bar diameter reduction of group $\mathrm{C}$ beams . 78

4.3 Comparison of theoretical and actual corrosion mass loss of rebars ............................... 78

4.4 Structural behavior of uncorroded and corroded beams .............................................. 80

4.4.1 Load vs deflection behavior and failure mode of uncorroded beams........................ 80

4.4.2 Load vs deflection behavior and failure mode of corroded beams........................... 87 
4.4.3 Comparative load-deflection behavior and failure mode- uncorroded and corroded beams

4.4.4 Post-cracking shear resistance, ductility and energy absorption capacity of uncorroded

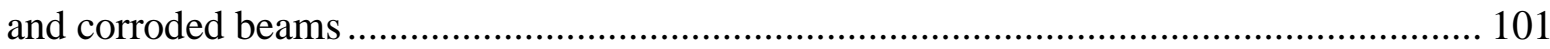

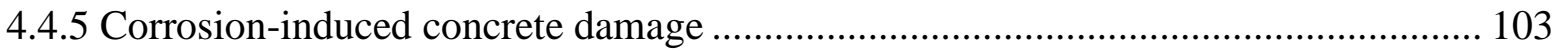

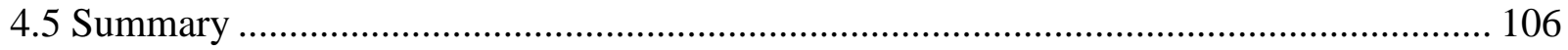

CHAPTER 5 : CONCLUSIONS AND RECOMMENDATIONS ...................................... 108

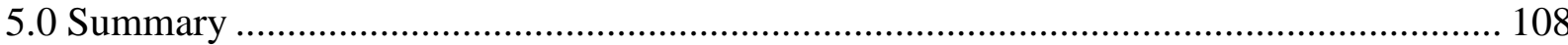

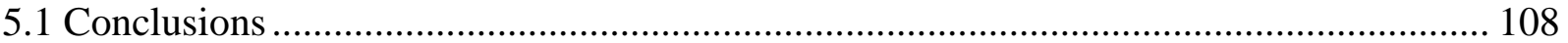

5.2 Recommendation for future research ................................................................ 110

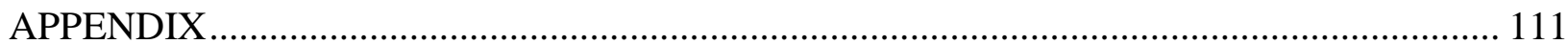

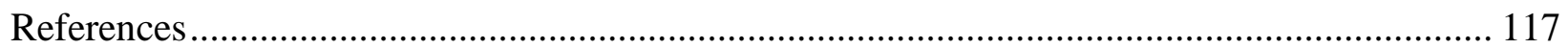




\section{LIST OF TABLES}

Table 2-1: Typical range of SCC mix composition (EFNARC, 2005)..................................... 12

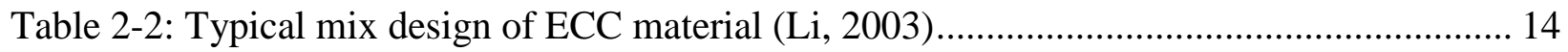

Table 2-3:Material charging sequence into ready-mix trucks (Li, 2007) ................................ 15

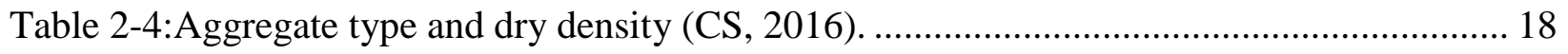

Table 2-5: Maximum dry loose bulk density of LWA for Structural Concrete (ASTM C330, 2014)

Table 2-6: Compressive Strength and Splitting Tensile Strength Requirements (ASTM C330, 2014)

Table 2-7: Geometrical and mechanical properties of PVA fiber ....................................... 23

Table 3-1: Beams descriptions, classifications, designations and dimensions ......................... 31

Table 3-2: Geometric dimensions of beams and reinforcement configuration.......................... 32

Table 3-3: Mix design of LWSCC and LWSCC with fiber............................................... 36

Table 3-4: Chemical and physical properties of cementing materials .................................... 36

Table 3-5: Lightweight slag aggregate gradation and properties........................................ 37

Table 3-6: Geometrical and mechanical properties of PVA fiber ....................................... 39

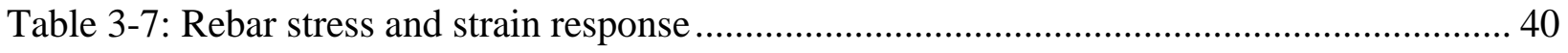

Table 3-8: Concrete strength and others properties at 28 days ........................................... 46

Table 3-9: Chloride Ion Penetrability of concretes (Siad, et al., 2015, Celasun, 2017) .............. 47

Table 3-10: Chloride Ion Penetrability Based on Charge Passed (ASTM C1202-12, 2012) ....... 47

Table 3-11: Classification of half-cell potential (Cor-Map-II, 2012) ...................................... 50

Table 4-1: Summary of Cracks and Spalling Observations .................................................. 63 
Table 4-2:Average half-cell potential reading along the bottom side and perimeter of the beams

Table 4-3: Summary of rebar mass loss, maximum crack width and the reduction of bar diameter

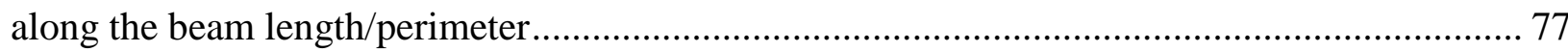

Table 4-4: Summary of strength, deflection and failure mode uncorroded beams........................ 82

Table 4-5:Summary of beam, SRF, DF, EAC and moment capacity uncorroded beams............. 86

Table 4-6:Summary of beam strength, deflection, failure mode of corroded beams .................... 91

Table 4-7: Summary of beam, SRF, DF, EAC and moment capacity corroded beams................. 92

Table 4-8: Summary of corroded beams failure mode and observation ................................... 104 


\section{LIST OF FIGURES}

Figure 1-1: Composite beams with different ECC layer thickness............................................. 3

Figure 2-1: Corrosion process, anodic and cathodic reaction on reinforcement (PCA, 2002) ....... 7

Figure 2-2: Steel inside the concrete/ correction protection (PCA, 2002) …………………........ 7

Figure 2-3: Four stages illustration of corrosion deterioration of RC beams (Higgins, et al.,

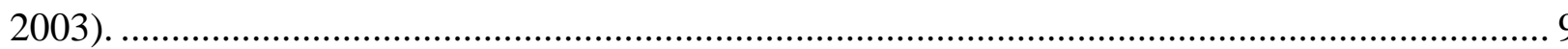

Figure 2-4: Corrosion effect on reinforced beams (Bartolini et al. 2004) ................................... 10

Figure 2-5: Self consolidating concrete construction (EFNARC, 2005) ....................................... 11

Figure 2-6: Self-consolidating concrete showing slump flow testing (EFNARC, 2005) .............. 11

Figure 2-7: Flexural Behavior of a PE-ECC (reinforced with high modulus polyethylene fibers)

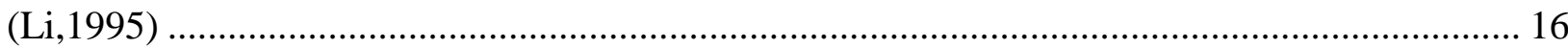

Figure 2-8: Lytag aggregate and internal pore structure (Lotfy, 2012)....................................... 19

Figure 2-9: Classification of lightweight concrete and types of aggregates used (Harding 1995)20

Figure 2-10: Ultimate tensile strain of ECC between (a) uncoated and (b) Coated fiber ( $\mathrm{Li}$, et al.,

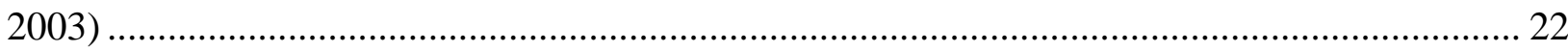

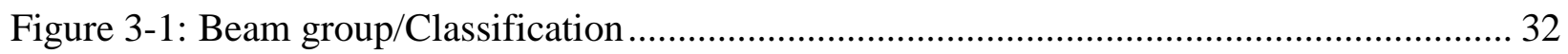

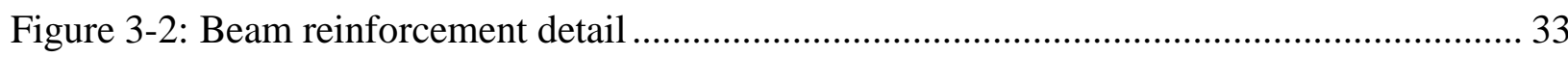

Figure 3-3: Cross-sectional details of full-depth/homogeneous beams showing reinforcement -

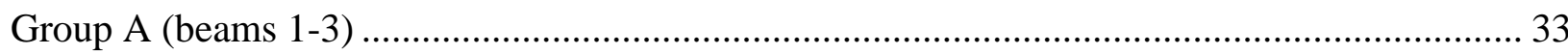

Figure 3-4: Cross-sectional details of composite beams with ECC layer showing reinforcement -

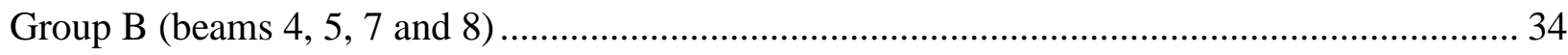

Figure 3-5: Cross-sectional details of composite beams with ECC wrapping showing reinforcement - Group B (beam 6).

Figure 3-6: Cross-sectional details of FRLWSCC beams with PVA, CR and HDPE fibers showing reinforcement - Group C (beams 9-11). 35 
Figure 3-7: Blast furnace slag as coarse and fine aggregates for LWSCC and FRLWSCC 37

Figure 3-8: HDPE, Crumb rubber and PVA fiber used for LWSCC and FRLWSCC ............... 38

Figure 3-9: Production of ECC using a Hobart type mixture .............................................. 39

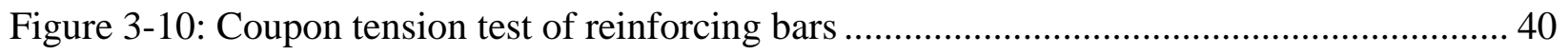

Figure 3-11: Stress-strain responses of reinforcing bars.................................................. 41

Figure 3-12 (a): Formwork showing reinforcement casing ............................................. 41

Figure 3-12 (b): Mould or formwork showing reinforcement casing and rebar assembly .......... 42

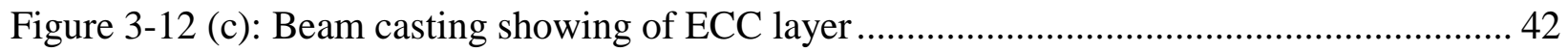

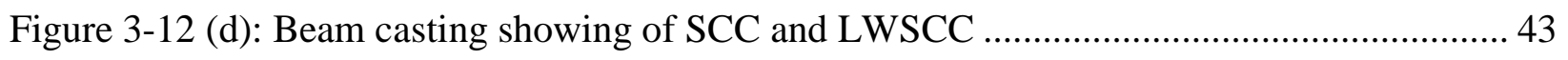

Figure 3-13(a): Curing of beams and control specimens for 24 hours in the form work ........... 43

Figure 3-13(b): Formwork removal after one day of casting and subsequent air curing ............ 44

Figure 3-14: Control specimens(Beam and Cylinder) ................................................... 45

Figure 3-15: Test set-up and instrumentation for flexural strength of beam specimens ............ 46

Figure 3-16: Flexural stress vs deflection responses of ECC, SCC, FRLWSCC and LWSCC ... 46

Figure 3-17(a): Accelerated corrosion test set-up - beams in tanks and DC power supply......... 49

Figure 3-17(b): Accelerated corrosion setup-connection and schematic diagram test setup....... 49

Figure 3-18: Half-cell potential measuring device ......................................................... 51

Figure 3-19(a) :Half-cell test location for side A of the beam............................................ 51

Figure 3-19(b): Half-cell test location for bottom side of the beam ..................................... 51

Figure3-19(c): Half-cell test location for side A of the beam............................................ 51

Figure 3-19(d): Sample snap-shot of half-cell potential survey …....................................... 52

Figure 3-20(a): Typical initial cracks in SCC beam after 6 days of current flow ..................... 53

Figure 3-20(b): Typical cracking and spalling after 11 days of current flow ............................. 53 
Figure 3-21: Rebar extraction from corroded beams using jack-hammer and broken beams ...... 54

Figure 3-22: Extracted corroded bars, bar segment and $\mathrm{HCl}$ acid in bottles for cleaning ........... 55

Figure 3-23: Experimental set-up and instrumentation showing fresh un-corroded beam.......... 56

Figure 3-24: Experimental set-up and instrumentation showing a corroded beam ................... 57

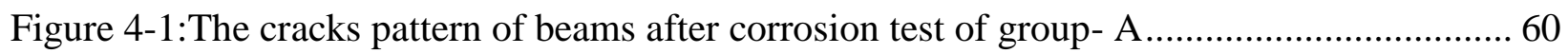

Figure 4-2: The cracks pattern of composite beams after corrosion test of group- B ................ 61

Figure 4-3:The cracks pattern and spalling of corroded beams after 11 days of corrosion test of

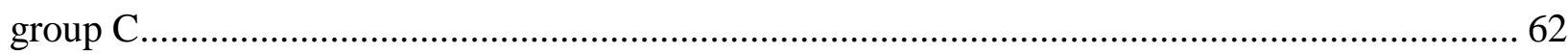

Figure 4-4: Side view of beams after 18 days of corrosion test of B1-C, B2-C, B3-C and A3-C64 Figure 4-5: Top view of corroded beams after 18 days' corrosion test: B1-C, B2-C, B3-C \& A3C.

Figure 4-6: Current flow-immersion time curve for 11 days' corrosion test........................... 67

Figure 4-7: Average current flow for all Eleven corroded beams ....................................... 68

Figure 4-8: Current flow-immersion time curve for 18 days' corrosion test........................... 69

Figure 4-9: Current flow-time immersion curves of FRLWSC beams.................................. 70

Figure 4-10: Half cell potential measuring tools .......................................................... 71

Figure 4-11: Average HCP vs immersion time curve for corroded beams of group A .............. 73

Figure 4-12: Average HCP vs immersion time curve for corroded beams of group B .............. 74

Figure 4-13: Average HCP vs immersion time curve of corroded beams of group C............... 75

Figure 4-14: HCP at different points vs immersion time curves of beam C3-C (LWSCC+1\%

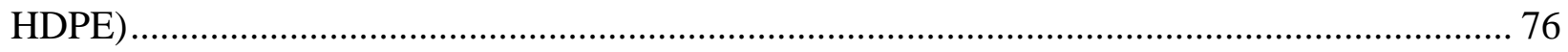

Figure 4-15: Comparison of actual and theoretical (Faraday's Law) mass loss ........................ 79

Figure 4-16: Percentage error of actual and theoretical bar mass loss ................................... 80 
Figure 4-17: Load vs deflection curves of uncorroded beams of group A ............................. 81

Figure 4-18: Load vs deflection curve of uncorroded beams of group B .............................. 83

Figure 4-19: Load vs deflection curve of uncorroded beams of group C ................................. 84

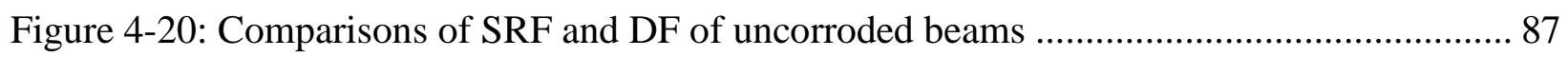

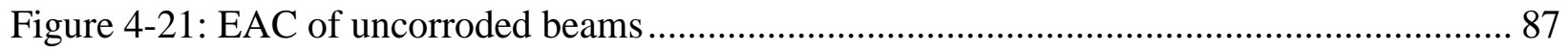

Figure 4-22: Load vs deflection curve of corroded beams group A ….................................. 88

Figure 4-23: Load vs deflection curve of corroded beams of group B .................................. 89

Figure 4-24: Load vs deflection curve of corroded beam of group C .................................... 90

Figure 4-25: Comparisons of SRF and DF of corroded beams ........................................ 93

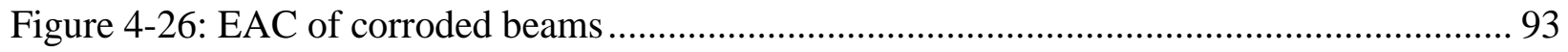

Figure 4-27: Load vs deflection curve of beams A1-F and A1-C ....................................... 95

Figure 4-28: Load vs deflection curve of beams A2-F and A2-C ....................................... 95

Figure 4-29: Load vs deflection curve of beams A3-F and A3-C ...................................... 96

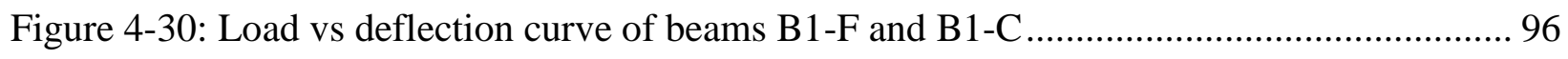

Figure 4-31: Load vs deflection curve of beams B2-F and B2-C ........................................ 97

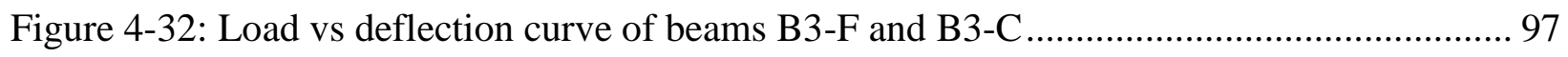

Figure 4-33: Load vs deflection curve of beams B4-F and B4-C ........................................ 98

Figure 4-34: Load vs deflection curve of beams B5-F and B5-C ......................................... 98

Figure 4-35: Load vs deflection curve of beams C1-F and C1-C....................................... 99

Figure 4-36: Load vs deflection curve of beams C2-F and C2-C........................................ 99

Figure 4-37: Load vs deflection curve of beams C3-F and C3-C ....................................... 100

Figure 4-38: Deflection of uncorroded vs corroded beams ............................................. 100

Figure 4- 39: Energy absorption capacity of fresh-uncorroded and corroded beams ............... 102 
Figure 4-40: Ultimate failure load of uncorroded, corroded beams and percentage of strength loss 102

Figure 4-41: Failure mode of Beam A2 ..................................................................... 103 


\section{LIST OF SYMBOLS AND ABBREVIATIONS}

SCC Self-consolidating concrete

LWSCC Lightweight self -consolidating concrete

LWC Lightweight concrete

LWA Lightweight aggregate

LWASCC Lightweight aggregate self -consolidating concrete

HPC High performance concrete

RC Reinforced concrete

VPC Volcanic pumice concrete

NC Normal concrete

VS Volcanic scoria

VP Volcanic pumice

FS Furnace slag

EC Expanded clay

ESH Expanded shale

SCM Supplementary cementing material

DF Ductility factor

DI Ductility index

ECC Engineered cementitious composite

EAC Energy absorption capacity

PP-ECC Polypropylene - Engineered cementitious composite

PE-ECC Polyethylene - Engineered cementitious composite

FRC Fiber reinforced concrete

HCP Half-Cell potential

HPFRCC High-performance fiber reinforced cementitious composites

HRWRA High range water reducing admixtures

FRLWSCC Fiber reinforced lightweight self -consolidating concrete

LVDT Linear variable differential transformers

NWC Normal weight concrete

PE Polyethylene

PVA Poly-vinyl-alcohol 


\begin{tabular}{ll} 
SCM & Supplementary cementing material \\
SRF & Shear resistance factor \\
Exp. & Experiment \\
VOC & Volatile organic compounds \\
GDP & Gross domestic product \\
$\mathrm{a} / \mathrm{d}$ & Shear span to depth ratio \\
$\mathrm{w} / \mathrm{c}$ & Water cement ratio \\
$\mathrm{w} / \mathrm{b}$ & Water binder ratio \\
$\mathrm{V}$ & Shear force in a concrete section \\
$\mathrm{V}_{\mathrm{a}}$ & Interlocking action of aggregates \\
$\mathrm{V}_{\mathrm{d}}$ & Dowel action \\
$\mathrm{V}_{\mathrm{n}}$ & Shear resistance of the beam \\
$\mathrm{b}$ & Width of the cross-section \\
$\mathrm{d}$ & Effective depth \\
$\mathrm{V}_{\mathrm{u}}$ & Ultimate shear force \\
$\mathrm{M}_{\mathrm{u}}$ & Ultimate moment capacity \\
$\mathrm{f}_{\mathrm{c}}$ & Cylinder compressive strength of concrete \\
$\mathrm{A}_{\mathrm{v}}$ & Area of shear reinforcement \\
$\mathrm{J}$ & Joules \\
$\mathrm{f}_{\mathrm{yt}}$ & Characteristic yield strength of reinforcement \\
$\mathrm{s}$ & Spacing of shear reinforcement \\
$\mathrm{h}$ & Total beam height \\
$\mathrm{f}_{\mathrm{t}}$ & Tensile stress of ECC \\
$\mathrm{D}_{\mathrm{y}}$ & Deflection \\
$\mathrm{D}_{\mathrm{c}}$ & Deflection at first diagonal crack \\
$\mathrm{D}_{\mathrm{u}}$ & Deflection at peak shear load \\
$\mathrm{a}$ & Depth of the equivalent compressive block \\
$\mathrm{a}$ & Balance depth of the compression zone \\
$\mathrm{A}_{\mathrm{f}}$ & Cross-sectional area of steel fibers \\
$\mathrm{A}_{\mathrm{s}}$ & Area of tensile steel bars \\
$\mathrm{a}$ & Shear span \\
\hline &
\end{tabular}



$\mathrm{A}_{\mathrm{s}}$
Minimum of tensile reinforcement
$\mathrm{A}_{\mathrm{v}}$
Area of shear reinforcement
$b_{t}$
The width of tension zone
$\mathrm{c}$
The distance of natural arises from the top fiber
$\mathrm{C}$
Concrete compressive force
$d_{a}$
Maximum aggregate size
$\mathrm{d}_{\mathrm{f}}$
Diameter of fibers
$\mathrm{D}_{\mathrm{f}}$
Lateral displacement at $80 \%$ of ultimate load at the descending part of the curve
$d_{v}$ Effective depth of concrete block
$\mathrm{D}_{\mathrm{y}}$
Lateral displacement at $80 \%$ of ultimate load at the ascending part of the curve
$\mathrm{E}_{\mathrm{f}}$
Modulus of elasticity of steel fibers
$\mathrm{F}$
Average pull out stress of fiber
$\mathrm{f}_{\mathrm{c}^{\prime}}$
Compressive strength of normal strength concrete
$\mathrm{f}_{\mathrm{cf}}^{\prime}$
Compressive strength of fibrous concrete
$f_{y}$
Yield strength of tensile reinforcement bar
$\mathrm{f}_{\mathrm{mc}}$
UHPC limiting compressive strength
$\mathrm{f}_{\mathrm{mt}}$
UHPC tensile stress
$\mathrm{G}_{\mathrm{m}}$
Shear modulus of concrete matrix
$\mathrm{h}$
The overall height of the beam
$1_{\mathrm{f}}$
Length of fibers
$\mathrm{M}_{\mathrm{f}}$
Moment resisting capacity of normal concrete
$\mathrm{M}_{\mathrm{n}}$
Nominal moment capacity of UHPC beam
$\mathrm{M}_{\mathrm{r}} \quad$ Resisting moment capacity
$\mathrm{N}$
Strain modular ratio
$\mathrm{r}_{\mathrm{f}}$
Radius of steel fibers
$\mathrm{S}$
Spacing between shear reinforcement
Tc
UHPC tensile force based on fiber contribution
$\mathrm{T}_{\mathrm{ECC}-1}$
ECC concrete tensile force
$\mathrm{T}_{\mathrm{ps}}$
UHPC steel reinforcement force
$\mathrm{T}_{\text {steel }}$
ECC tensile force of steel
$\mathrm{V}_{\mathrm{c}}$
Concrete shear capacity 


\begin{tabular}{|c|c|}
\hline$V_{f}$ & Volume fraction of fibers \\
\hline $\mathrm{V}_{\mathrm{m}}$ & Volume fraction of the matrix \\
\hline $\mathrm{V}_{\mathrm{p}}$ & Shear resistance capacity of pre-stress reinforcement \\
\hline $\mathrm{V}_{\mathrm{s}}$ & Shear resistance of stirrups \\
\hline $\mathrm{V}_{\text {shear }}$ & Resisting shear capacity \\
\hline$\alpha_{1}$ & Concrete stress block parameter \\
\hline$\beta_{1}$ & Concrete stress block parameter \\
\hline$\varepsilon_{\mathrm{c}}$ & Concrete Strain \\
\hline$\varepsilon_{\mathrm{f}}$ & Fiber tensile strain \\
\hline$\varepsilon_{\mathrm{m}}$ & UHP Concrete compressive strain at the top fiber \\
\hline$\varepsilon_{\mathrm{m}}$ & UHP Concrete tensile strain \\
\hline$\varepsilon_{\mathrm{p}}$ & UHPC reinforcement strain \\
\hline$\varepsilon_{\mathrm{y}}$ & Reinforcement strain \\
\hline$\varepsilon_{\mathrm{ecc}}$ & Yield strain of ECC \\
\hline$\varepsilon_{\text {steel }}$ & ECC yield strain of steel \\
\hline$\rho_{\mathrm{s}}$ & Longitudinal reinforcement ratio \\
\hline$\sigma_{\mathrm{c}}$ & Ultimate tensile strength of steel fiber reinforced composite prior to cracking \\
\hline$\sigma_{\mathrm{f}}$ & Ultimate pull out strength of steel fiber \\
\hline$\sigma_{\mathrm{m}}$ & Ultimate tensile strength of un-cracked concrete matrix \\
\hline$\varphi_{\mathrm{c}}$ & Concrete Reduction factor \\
\hline$\varphi_{\mathrm{s}}$ & Steel reduction factor \\
\hline$\lambda$ & Concrete stress block parameter \\
\hline$\eta_{\mathrm{b}}$ & Fiber bond efficiency factor \\
\hline
\end{tabular}




\section{CHAPTER 1 : INTRODUCTION}

\subsection{General}

Reinforced concrete is the most commonly used construction material worldwide (Sideris \& Savva, 2005). The reinforced concrete is widely accepted for its structural flexibility, long-term durability characteristics and the continuous contact of its ingredients, namely the reinforcing steel and concrete. Appropriate design and construction of reinforced concrete structure ensured the protection of steel against corrosion during the service life of the structure. Nevertheless, this concrete cover protection to the reinforcement can be deteriorated by aggressive agents leading to the corrosion of the steel in concrete (Hariche et al. 2012).

Over the last decades new generation of high performance concretes (HPCs) with improved flowability, rheology, strength, durability, ductility and energy absorbing capacity have been developed. Self-consolidating concrete (SCC) is one of such HPCs which is flowable, achieves good consolidation, and can flow into place between congested reinforcement without vibration and without defects due to bleeding or segregation (Ozawa et al., 1989; Li, 1995; Lachemi et al., 2003; Poon \& Ho, 2004b). SCC is now extensively used all over the world (Karahan et al., 2012). SCC was developed in Japan to improve the uniformity and reliability of concrete (Seddik, et al., 2013). Different types of SCCs have been developed to meet users' requirements. Two of the latest innovations in SCC technology is lightweight SCC (LWSCC) and Fiber reinforced lightweight SCC (FRLSWCC) (Okamura \& Ouchi 2003). Over the last century, structural lightweight concrete (LWC) has been developed and widely used to build building components (Hossain, 2004a,b). The density of structural LWC typically ranges from 1400 to $2000 \mathrm{~kg} / \mathrm{m}^{3}$ (ACI 211.2 1981; Bamforth 1987). LWSCC combines all the best properties of the lightweight concrete (LWC) with the best properties of the SCC (Lotfy et al. 2016a,b; Behnam \& Shami, 2016). LWSCC mixtures have exhibited satisfactory durability and satisfied the criteria for structural concrete. Similarly, FRLWSCC also combines the best properties of fiber reinforced concrete (FRC) and LWSCC. Over the last years, research at Ryerson University has developed SCC, LWSCC and FRLWSCC (Lachemi et al. 2003; Hossain \&Lachemi 2010; Karahan et al. 2012; Lotfy et al. 2016a,b; Celasum 2016).

In order to achieve better performance from concrete, notable research is being conducted worldwide with the aim of creating new composites, which will increase shear and flexural 
strength as well as the ductility of the structural concrete elements. Many researchers have been done to develop a composite material known as Engineered Cementitious Composite (ECC). Micromechanical design allows optimization of ECC for high performance, resulting in extreme tensile strain capacity while minimizing the amount of reinforcing fibers, typically less than $2 \%$ by volume. Unlike ordinary cement-based materials, ECC strain hardens after first cracking and demonstrates a strain capacity 300 to 500 times greater than normal concrete through the use of incorporating fibers. Even at large imposed deformation, crack widths of ECC remain small, less than $60 \mu \mathrm{m}(\mathrm{Li}, 1997$; Lin \& Li, 1997; Lin et al., 1999). Flexibility nature of ECC which came into view from laboratory testing to field applications leads to speedy construction, reduced maintenance and a longer life span for the structures (Li \& Kanda, 1998; Wang \& Li, 215). Polyvinyl alcohol (PVA) fiber is successfully used in the production of moderate strength ECC. (Li, 1998).

In the last few decades, many research is being conducted to create a new structural elements or systems with HPCs or combination of HPCs to optimise increase strength, ductility and durability. New type of green cost-effective ECCs comprising locally available aggregates/industrial wastes (Sahmaran, 2009; Ozbay et al., 2011; Sherir, 2012) have been developed by Ryerson's research team and their potential applications in 'joint-free bridge deck with link slab', 'composite framed shear wall system' and 'coupling slab in shear wall structures' (Issani \& Hossain, 2013; Rafiei et al., 2013; Hossain \&Taormina, 2012). Recently, shear and flexure performances of composite beams with different combinations of ECC and SCC has been evaluated by Hasib \& Hossain (2016). Composite beam is a structural member composed of two or more dissimilar material joined together to act as a unit. Figure 1-1 shows schematic of typical composite beams with ECC layer thickness embedding the main reinforcement and ECC wrapping embedding the core concrete. 
Commonly, corrosion of steel in concrete is one of the major causes of premature deterioration of reinforced concrete constructions, such as bridges, parking decks, tunnels, offshore structures, leading to structural failure. When aggressive agents come into contact with the reinforcement due
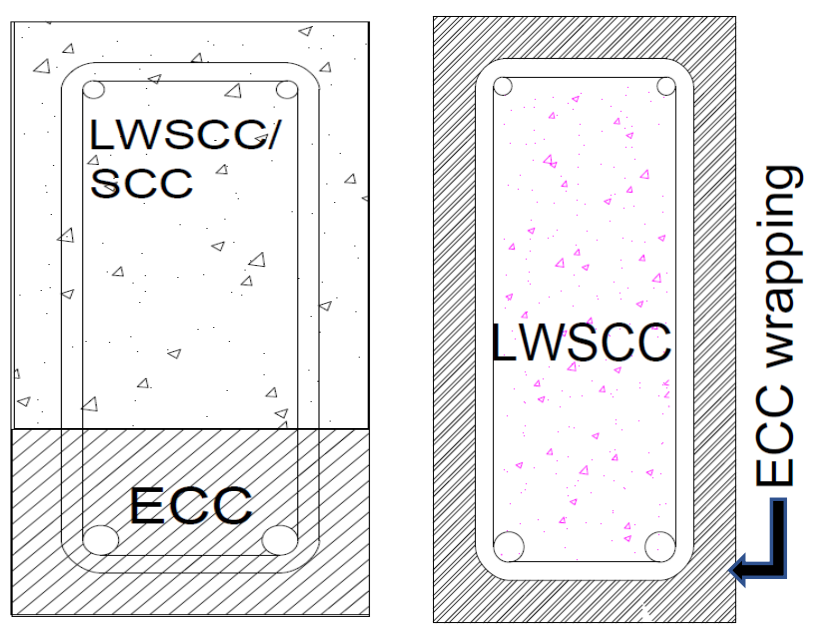

Figure 1-1: Composite beams with different ECC layer thickness

to chloride attack or carbonation of concrete cover, corrosion may start and affect, for example, the steel reducing its bar diameter and mechanical property. The concrete cover cracks due to the expansion of a corrosion substance (Andrade et al.,1993), reducing the compound action of concrete and steel due to bond deterioration (Rodriguez et al., 1994).

The most important effect of the corrosion process is the formation of rust, whose volume is greater than steel (from two to six times depending on environmental conditions). The consequences of rust are cracking and spalling of the concrete, which can influence various characteristics such as the mechanical performance and load capacity of the concrete structures. (Broomfield, 2002).

The rate corrosion depends on the availability of oxygen and water near the concrete surface and therefore a purpose of the permeability of the concrete protecting the reinforcement. Also, surrounding environment plays a vital role, frequently wetting and drying is one of the most severe conditions. One of the measures can be taken to increase the durability of the concrete structure to increase the resistance of concrete to enter into chloride ions. High-performance concrete (HPC) containing silica fumes, slag, or

is characterized by its improved pore structure with a dense matrix and low permeability, and these factors can offer protection against corrosion (Gowripalan \& Mohamed, 1998). 
During last decades numerous materials, methods and systems have been tested to prevent corrosion of reinforcement in concrete, including corrosion inhibitors, epoxy coated rebars, galvanized steel bars with a sacrificial zinc layer, and low permeability HPCs. Each method alone provides insufficient protection to the steel reinforcement due to the complex nature of corrosion.

\subsection{Research significance}

Reinforcement corrosion is a critical problem that affects both the structural safety and the economic value of corroded concrete structures and their surrounding environment. The global corrosion cost is estimated to be 2.5 trillion, which is $3.4 \%$ of global GDP in 2013 (Koch, et al., 2016). HPCs are widely used in many structural applications over the last decades for their better structural and durability performance. Although the structural performance and corrosion resistance of SCC and FRC structural elements were the subject matter of previous research studies, limited research has been conducted on the corrosion resistance of structural elements made of ECC, LWSCC and FRLWSCC. No research has been conducted on the corrosion resistance of composite structural elements made of combinations of ECC and SCC or ECC and LWSCC which warrants investigation on this aspect. The use of ECC as layer or wrapping protecting the reinforcement in composite beams can enhance corrosion resistance, structural performance and service life. Moreover the lower corrosion resistance and structural performance of comparatively weak and porous LWSCC based structures can be improved through developing ECC-LWSCC composite structural elements. The proposed research on the evaluation of corrosion resistance of beams made of different types of HPCs and their combinations as well as subsequent structural performance of corroded and uncorded beams will contribute to the existing knowledge of such technology.

\subsection{Research scope and objectives}

The objectives of this research are to evaluate experimentally the corrosion resistance and structural performance of SCC, LWSCC, FRLWSCC, ECC and composite beams made of SCC or LWSCC with ECC layer or wrapping. The objectives of this research will be achieved through:

$\checkmark$ Investigation on corrosion resistance of reinforced full depth SCC/ECC/LWSCC/FRLWSCC and SCC-ECC or LWSCC-ECC composite beams (with ECC layer or wrapping) based on accelerated corrosion tests. The performance will be judged based on current measurement, cracking, corrosion rate, half-cell potential readings, 
rebar mass loss and rebar diameter degradation along the length as well as comparing theoretically calculated rebar mass loss by Faraday's law to actual mass loss.

$\checkmark$ Studying the structural performance of corroded and uncorroded reinforced full depth SCC/ECC/LWSCC/FRLWSCC and SCC-ECC or LWSCC-ECC composite beams. The performance will be judged based on crack patterns, loads at the first flexure/diagonal cracking, post-cracking shear resistance/ductility, ultimate shear resistance, load-deflection response, energy absorbing capacity and failure modes.

$\checkmark$ Comparing the test results of corroded and uncorroded beams to evaluate corrosion and structural performance.

$\checkmark$ Studying the influence of HPCs on the corrosion resistance and improvement of structural performance.

$\checkmark$ Studying the influence of ECC layer or wrapping on the corrosion resistance and improvement of structural performance.

$\checkmark$ Making recommendations based on research findings on the potential of such construction in practical applications

\subsection{Thesis outline}

This thesis consists of five chapters.

Chapter 1 provides an introduction, scope, and objectives of the research.

Chapter 2 provides a literature review on corrosion basics, properties, mix design and applications of various types of HPCs and research studies conducted on corrosion resistance and structural performance of HPC structural elements.

Chapter 3 introduces the experimental program including details concerning specimen identification, materials used, the procedures for constructing and curing of specimens as well as details of accelerated corrosion and structural testing.

Chapter 4 provides the results of corrosion tests and structural testing of uncorroded and corroded reinforced beams with detailed analysis and discussions.

Chapter 5 presents the conclusion and recommendations for further research studies. 


\section{CHAPTER 2 : LITERATURE REVIEW}

\subsection{Introduction}

Corrosion resistance and structural performance are significant issues for the application of new generation of high performance concretes (HPCs) such Self-Consolidating Concrete (SCC), Lightweight Self-Consolidating Concrete (LWSCC), Fiber reinforced Self-Consolidating Concrete (FRLWSCC) and Engineered Cementitious Composite (ECC) in reinforced concrete (RC) construction. The composite beams made of combination of SCC and LWSCC with highly durable ECC with superior strain hardening, multiple micro-cracking and durability characteristics can improve structural and corrosion resistance performance. This chapter describes the following: Corrosion basics, properties and mix design of SCC, ECC and LWSCC, Applications of $\mathrm{SCC} / \mathrm{ECC} / \mathrm{LWSCC}$, research studies conducted on corrosion in SCC/LWSCC/ECC/ composite beams and a summary to demonstrate the need for proposed research study in the context of the new HPC based technology.

\subsection{Corrosion basics}

\subsubsection{Introduction}

Corrosion is one of the most considerable threats for durability reinforced concrete structures. This section describes the fundamentals of some aspects of corrosion, including the environments that lead to corrosion and issues which influence the degree of corrosion, with the focus on corrosion initiated by chloride ions, as this was the system used to initiate corrosion for the experimental work.

\subsubsection{Corrosion Environment}

Steel, similar to most metals except gold and platinum, is thermodynamically unstable under usual atmospheric environments and will release energy and revert to its natural state-iron oxide, or rust. This process is called corrosion (PCA, 2002). To generate corrosion, three elements must be present - minimum two metals at different energy levels, an electrolyte and a metallic connection.

\subsubsection{Corrosion process}

Corrosion is an electrochemical process connecting the flow of charges (electrons and ions) (PCA, 2002). Figure 2-1 shows corrosion process in reinforcement. Anode is called at active sites of the bar, iron (Fe) atoms lose electrons and move into the surrounding concrete as ferrous ions( $\mathrm{Fe}+)$. This process is called a half-cell oxidation reaction (Equation 2.1), or the anodic reaction, and free electrons combine with water and oxygen in the concrete. The reaction at the cathode is called a 
reduction reaction (Equation 2.2). Then the ferrous ions migrate through the concrete pore water to these cathodic sites where they combine to form iron hydroxides, or rust (Equation 2.3) (PCA, 2002). All the reactions are represented as follows:

Anode: $\quad 2 \mathrm{Fe} \rightarrow 2 \mathrm{Fe}^{2+}+4 \mathrm{e}^{-}$

Cathode: $\quad 2 \mathrm{H}_{2} \mathrm{O}+\mathrm{O}_{2}+4 \mathrm{e}^{-} \rightarrow 4 \mathrm{OH}^{-}$

Cathode: $\quad 2 \mathrm{Fe} 2++4 \mathrm{OH}-\rightarrow 2 \mathrm{Fe}(\mathrm{OH})$

This initially precipitated hydroxide tends to react further with oxygen to form higher oxides. The majority of ordinary rust consists of hydrous ferric oxide and is orange to red-brown in color.

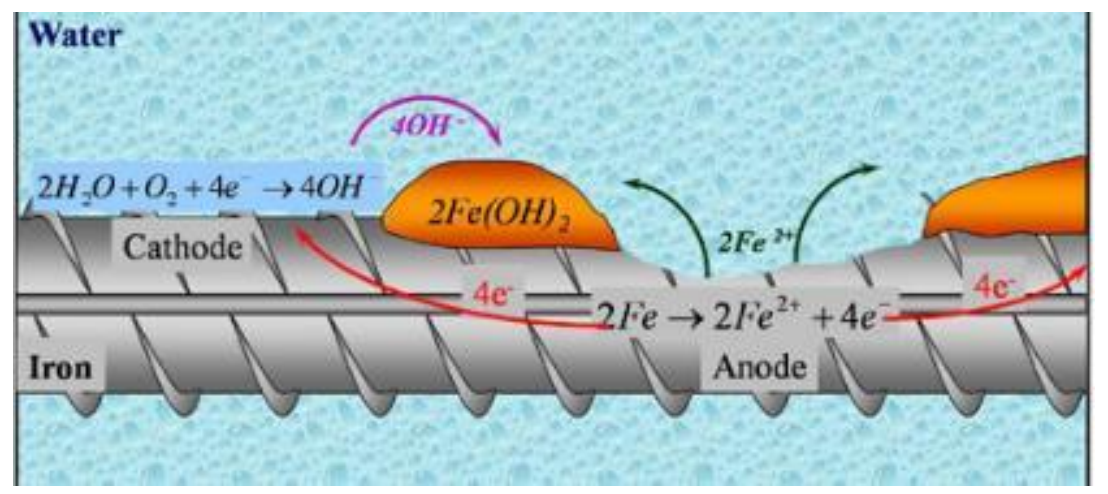

Figure 2-1: Corrosion process, anodic and cathodic reaction on reinforcement (PCA, 2002)

\subsubsection{Resistivity of Concrete and the passive layer}

The natural tendency of steel is to undergo corrosion reactions, concrete contains a high level of the alkaline environment ( $\mathrm{p}^{\mathrm{H}}$ of 12 to 13 ), which provides the corrosion protection of steel. At the high $\mathrm{p}^{\mathrm{H}}$, a thin oxide layer forms on the steel and prevents metal atoms from dissolving. This

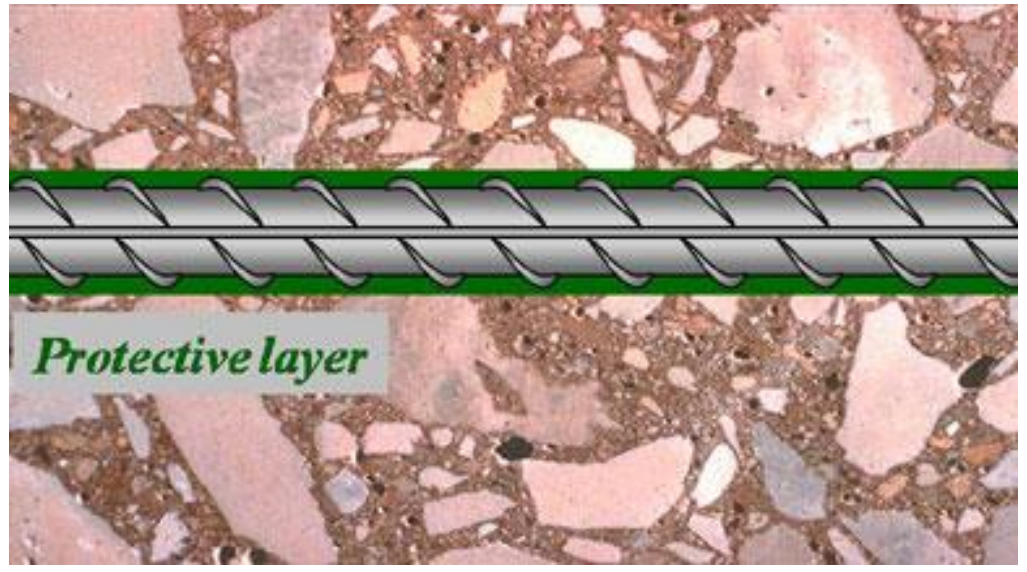

Figure 2-2: Steel inside the concrete/ correction protection (PCA, 2002) 
passive film does not stop corrosion; it reduces the corrosion rate to an insignificant level. Figure 2-2 shows the steel inside the concrete protection. The passive corrosion rate of steel in concrete is typically $0.1 \mu \mathrm{m}$ per year. Short of the passive film, the steel would corrode at rates at least 1,000 times higher (ACI 222, 2001). Concrete has good resistivity and its rest on moisture content and pore structure of the concrete which lead the corrosion process. Reinforcing steel does not corrode in most concrete elements and structures, because of concrete's inherent protection. Nevertheless, when the passive layer is destroyed, corrosion can occur. The destruction of the passive layer occurs due to reduction of the alkalinity and increase the chloride concentration in the concretes a certain level.

\subsubsection{Chloride induced corrosion}

Chloride ions are one of the most common causes of initiation of corrosion of steel in concrete (PCA 2002; Hossain 2005, 2006; Hossain et al. 2009). The source of chlorides may be admixtures, pollutants, marine environments, industrial salt water, or de-icing salts. The real mechanism of breakdown of the passive film by chlorides is still unknown, due to its works on an atomic scale in the extremely thin passive layers. Nonetheless, the most common theory is that chloride ions can enter the protective oxide film easier than do other ions, and send-off the steel vulnerable to corrosion (PCA, 2002).

The negative effect of chlorides on reinforced concrete, (Hunkeler, 2005.):

- Chloride wrecked the passive film of steel and make corrosion attack essay

- A decrease of the solubility of $\mathrm{Ca}(\mathrm{OH})_{2}$, resulting in a lowered $\mathrm{p}^{\mathrm{H}}$ of the pore water

- A growth in the moisture content of the concrete due to the hygroscopic nature of salts $\left(\mathrm{NaCl}, \mathrm{CaCl}_{2}\right)$

- A rise in the electrical conductivity of the concrete.

- The devastation of the passive layer making corrosion possible.

\subsubsection{Mechanism of chloride attack}

The actual mechanism of breakdown of the passive film by chlorides is still under speculation. There are three modern theories that propose the mechanisms of the chloride attack on reinforcing steel (Gu et al., 2001) as described below:

1. The Oxide Film Theory - The oxide film is responsible for passivity and protection of the rebar against corrosion. As chloride ions penetrate the film easier than other ions 
(e.g. $\mathrm{SO}_{4}^{-2}$ ). Otherwise, as chloride ions may colloidally scatter the oxide film, making it easier to penetrate.

2. The Adsorption Theory - Chloride ions grasp the rebar surface in competition with dissolved $\mathrm{O}_{2}$ or hydroxyl ions. At this moment chloride ion encourages the hydration of the iron ions and thus helps the corrosion of steel.

3. The Transitory Complex Theory - The chloride ions become combine in the passive film replacing some of the hydroxides. This mechanism raising the both conductivity and solubility of the passive layer. Therefore, the film loses its protective qualities.

\subsubsection{Deterioration process}

According to Higgins et al. (2003) the deterioration progression of reinforced concrete beams can be divided into four stages: Stage 1: As initiation of corrosion when the reinforcing steel is passivated by either a chloride or a carbonation attack; Stage 2: The dissemination of corrosion, which leads to the cracking of the concrete and rust staining on the surface; Stage 3: Cracking showed and delaminating of the concrete, the rate of corrosion accelerated due to the increased accessibility of moisture and chloride ions; Stage 4: Spalling occurred of the concrete cover, exposing the reinforcing steel to the full the impact of the corrosive environment. Figure 2-3 shows of these four-stage corrosion deteriorations of steel in $\mathrm{RC}$ beams.
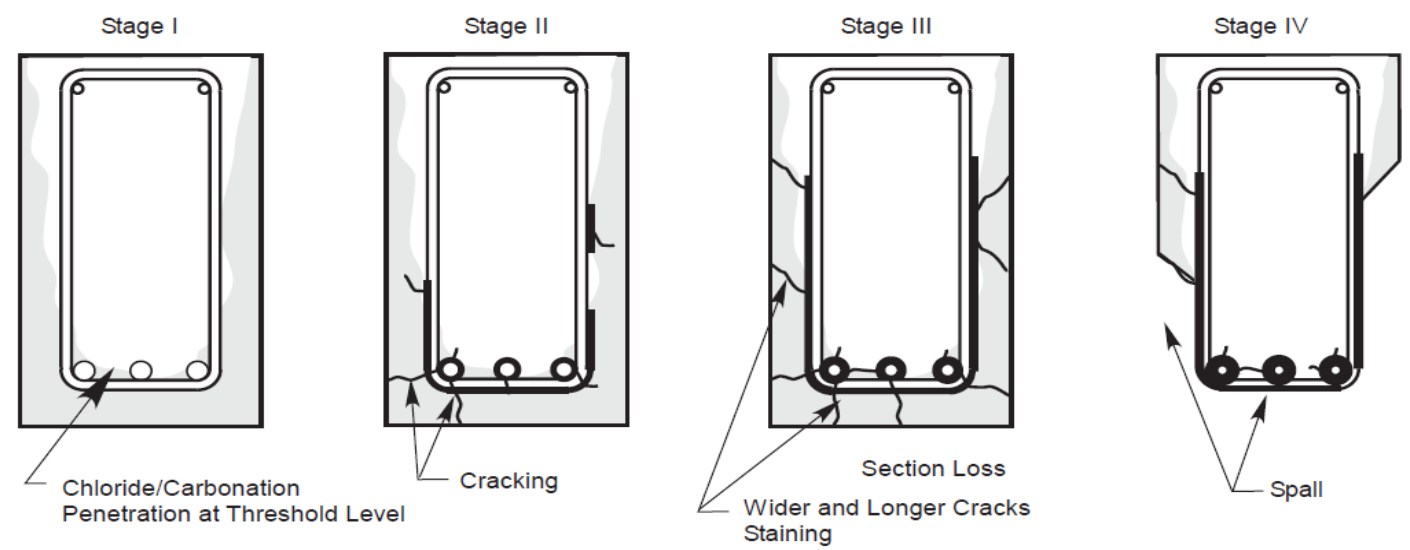

Figure 2-3: Four stages illustration of corrosion deterioration of RC beams (Higgins, et al., 2003).

The major structural consequences of corrosion are shown in figure 2-4. The products of corrosion cause increase the volume of steel and increase tensile stresses in the concrete that produce cracks, 
spalling, and or delamination. The result is the deterioration and decrease of the steel-concrete bond. These effects are initiated by corrosion and their severity increases over the time (Bertolini et al. 2004).

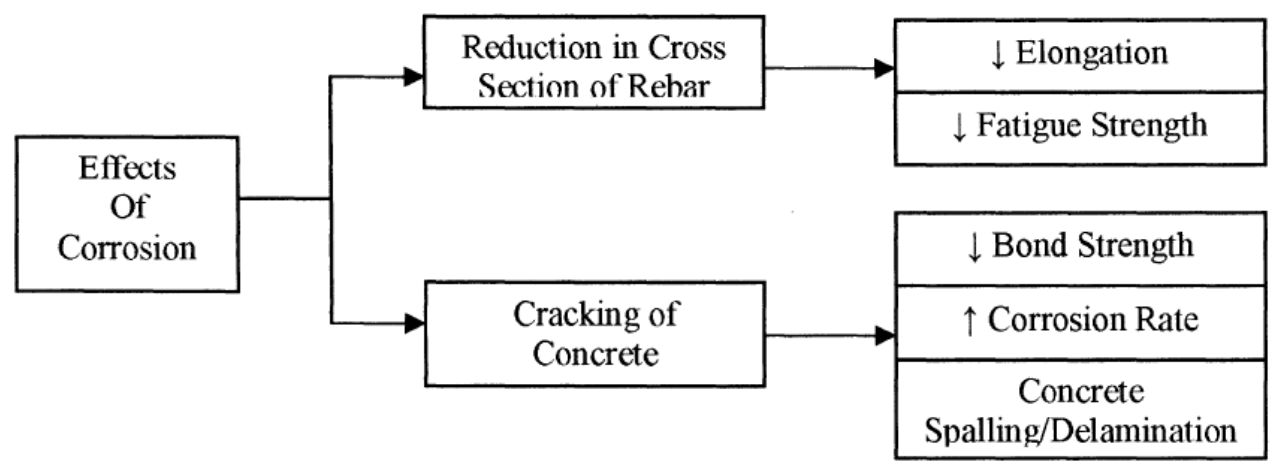

Figure 2-4: Corrosion effect on reinforced beams (Bartolini et al. 2004)

\subsection{Self-consolidating concrete (SCC)}

\subsubsection{Introduction of SCC and mix design}

Normal concrete (NC) requires proper compaction or vibration to achieve optimum benefits from concrete structure. Proper compaction and vibration ensure that concrete fills all voids in the formwork eliminating unwanted entrapped air. Past few years, there has been significate increase in the use of self -consolidating concrete (SCC). SCC is extensively used all over the world (Karahan, Hossain, Ozbay, Lachemi, \& Sancak, 2012). SCC was developed in Japan to improve the uniformity and reliability of concrete (Seddik et al., 2013).

According to Daczko (2012), "Self-compacting concrete (SCC) is an innovative concrete that does not require vibration for placing and compaction. It can flow under its own weight, and full compaction possible in congested reinforcement. The hardened concrete is homogeneous, dense, and has the same engineering properties and durability as traditional vibrated concrete." Figure 2-5 shows SCC placing without compaction. Hassan et al. (2010) discussed selfconsolidating concrete has excellent deformability and high resistance to segregation and could be filled in heavily reinforced or congested area without vibration. 


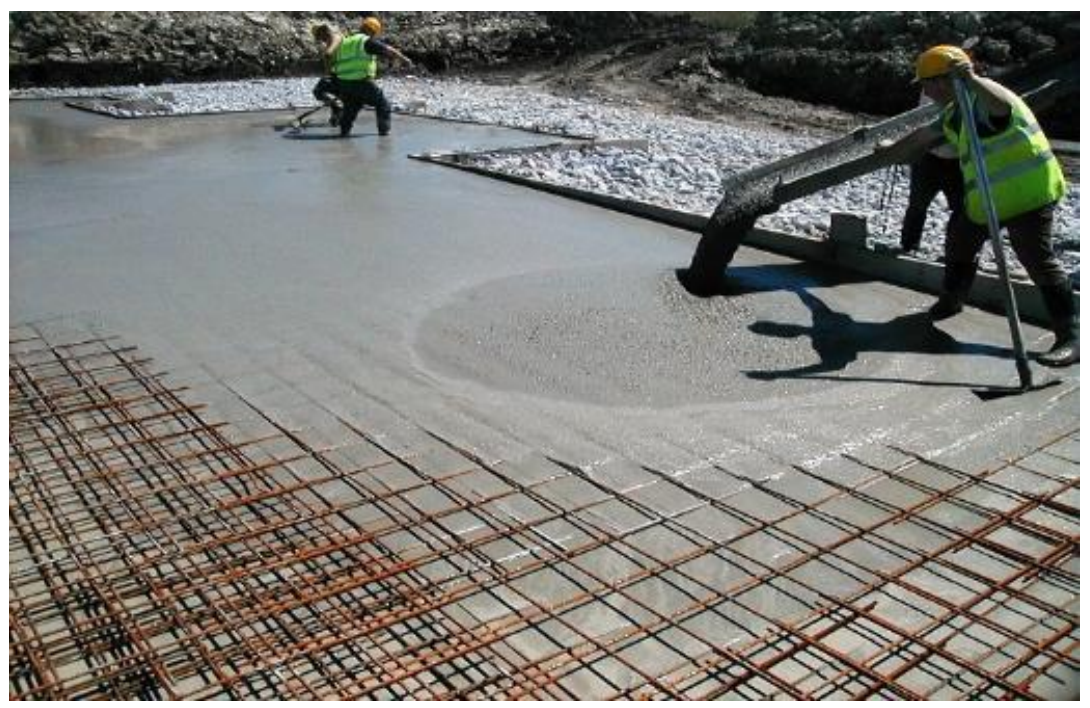

Figure 2-5: Self consolidating concrete construction (EFNARC, 2005)

SCCs require little workmanship, are easily pumpable and make little noise. Hypothetically, SCCs are gaining acceptance in casting columns, walls, beams and complex structures where pouring of normal concrete is critical. Also, these are currently used in pre-cast plants because they simplify and quicken the pouring of concrete, increase the life of molds and reduce the noise level in the plant. Figure 2-6 shows slump flow of SCC.

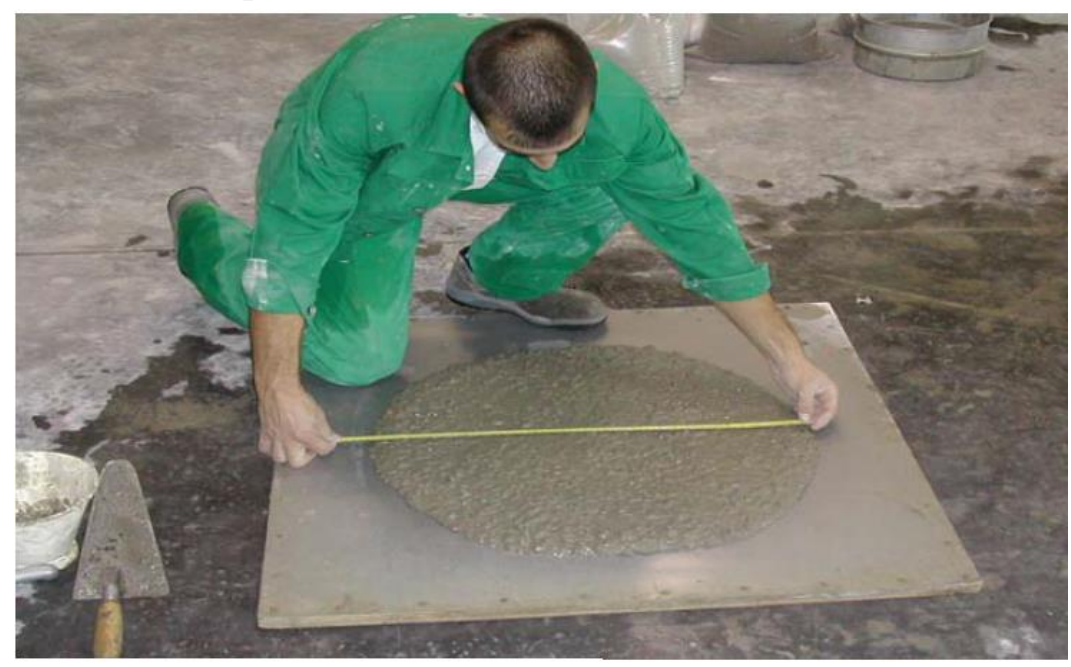

Figure 2-6: Self-consolidating concrete showing slump flow testing (EFNARC, 2005)

SCCs can flow much better while preventing segregation due to adding chemical admixtures, primarily super-plasticizers, and decreasing the coarse-to-fine aggregate ratios. Also, the water 
demand is reduced due to adding super-plasticizers; the strength and durability might be increased, (Hassan, Hossain, \& Lachemi, 2009).

\subsubsection{Application of SCC and Typical mix design}

The European Guidelines for Self-Compacting Concrete (2005) recommend SCC as an innovative concrete which does not any require any vibration and compaction. SCCs can flow under this selfweight, and the formwork completely fills up and achieves full compaction by self-weight, though in the presence of clogged reinforcement. The hardened concrete is compressed and homogeneous, and contains the same engineering property and durability as ordinary vibrated concrete. SCC offers a quick rate of placement, with faster construction time and easy flow around the congested reinforcement. Adding superplasticizers or high range water reducing admixtures conforming the fluidity and segregation resistance of SCC ensures a high level of homogeneity, minimum void and uniform strength, confirming the superior level of finish surface and durability of the structure. SCC develops high early strength due to its low water-cement ratio, which allows the formwork to be de-molded and makes faster reuse possible. SCC can improve the environment near the contraction site and pre cast site due to the elimination of vibration and noise. Also, it has health and safety benefits for both precast and cast in-situ civil construction (EFNARC, 2005). The high flowability of SCC can result in flotation, leak- proof metal, so high-quality formworks are recommended for SCC construction. (EFNARC, 2005). Typical mix design of SCC showing range of ingredients is presented in Table 2-1.

Table 2-1: Typical range of SCC mix composition (EFNARC, 2005)

\begin{tabular}{llc}
\hline Constituent & $\begin{array}{l}\text { Typical range by mass } \\
\left(\mathrm{kg} / \mathrm{m}^{3}\right)\end{array}$ & $\begin{array}{l}\text { Typical range by volume } \\
\left(\text { litter/m } \mathrm{m}^{3}\right)\end{array}$ \\
\hline Powder & $380-600$ & $300-380$ \\
Paste & & $150-210$ \\
Water & $150-210$ & $270-360$ \\
Coarse aggregate & $750-1000$ & $0.85-1.10$ \\
\hline Fine aggregate (sand) & Content balances the volume of the other constituents, typically \\
& $48-55 \%$ of total aggregate weight. \\
\hline Water/Powder ratio by vol. & \multicolumn{2}{c}{0.85} \\
\hline
\end{tabular}

Lacombe et al. (1999) investigated the potential of self-consolidating concrete to perform overhead repairs. Three types of repair materials such as SCC, normal concrete and shotcrete were used in this experiment. Three concrete blocks $(800 \times 800 \times 300 \mathrm{~mm})$ were used for repair depth around $40 \mathrm{~mm}$ at the bottom side of each sample. Viscosity modifying admixture (VMA) and a 
superplasticizer were used in the SCC mixture to reduce bleeding and segregation. The block was repaired for each conventional method, and after seven days all specimens were cut for visual inspection and well as scanning electron microscope (SEM) inspection. The results showed that the normal concrete did not possess suitable rheological properties and filling capacity in overhead maintenance. It entrapped air and developed segregation. SCC repair performed satisfactorily in terms of filling, bonding, and rheological properties. The SEM analysis showed there was no perturbation on the surface. However, the SCC cost was high due to using VMA and super plasticizers. The shotcrete bonding was found to be almost perfect but skilled labor was required. The research also recommended further cost effective SCC investigations in order to use repair materials (Lacombe et al, 1999).

SCC was introduced to build Akashi Straits Bridge- the world's longest suspension bridge in Japan (Okamura \& Ozawa, 1994). The bridge used 520,000 $\mathrm{m}^{3}$ of concrete for one Anchorage and $250,000 \mathrm{~m}^{3}$ for another. Embedded in the Anchorage was the cable anchor frame weighing 8,820 kips. Each day $1,900 \mathrm{~m}^{3}$ concrete had to be placed in the anchorage. In order to improve the construction, 40mm size aggregate was developed and used. SCC concrete was mixed in the batch plant near the site and pumped out from the plant to the site for $200 \mathrm{~m}$ through 6 trains of $200 \mathrm{~mm}$ pipes. At the site, the pipes were arranged in rows of 3 to $5 \mathrm{~m}$ apart. The concrete was cast from gate valves situated at $5 \mathrm{~m}$ intervals. In order to maintain the minimum level surface of cast concrete used automatically controlled valves. The concrete had a maximum drop of $3 \mathrm{~m}$ without any segregation regardless any size of aggregate. The use of SCC help to reduce the construction time by 20 percent from 2.5 years to 2 years (Okamura \& Ozawa, 1994).

$\mathrm{Li}$ (1995) claimed that the use of self-placing concrete in Japan and the viable benefit gained by the firm when producing their own though still, it is $30 \%$ higher than the USA. SCC had been used since 1993 in Japan. Two projects mentioned in this article. One was the Kiba-Park large Bridge, a $151 \mathrm{~m}$ cable-stayed pre-stressed concrete bridge was required two workers to place $650 \mathrm{~m} 3 \mathrm{SCC}$ in nine months. The motivation to use SCC was difficulty and high labor cost to pour normal concrete in congested reinforce the concrete structure. The another one was 70 Story Landmark building, the tallest building in Japan in 1993, where concrete pumped 885m into steel tubular Li (1995). 


\subsection{Engineering cementitious concrete (ECC)}

\subsubsection{Introduction and Mix design}

Civil infrastructures are always subject to multi-hazards such as earthquakes, fires, the wind, storm surges. Ultimate protection from natural calamities failure of infrastructure cannot be assured even though with many decades of investigations in structural design and materials development (Sherir, 2012). Development of high strength concrete led to developing stronger structure but most of these concretes remain brittle as compressive strength goes up. This is one of the limitations of using high strength concrete in a structural application. In a critical location where stress concentration is high could lead to fracture failure of the concrete. High ductility materials can help structure in seismic response of the whole structure. In the last few years, many researchers have been done to develop a composite material known as Engineered Cementitious Composite (ECC). ECC is designed in order to achieve high durability, high ductility and strain capacity varying between 3 to $5 \%$ under tensile loading with only $2 \%$ fiber content by volume. The incorporation of $2 \%$ of fiber content leads to a vital behavior of high tensile ductility and strain capacity of 300-500 times greater than the tensile strain capacity of normal concrete (Li, 1998). Table 2-2 shows the typical ECC mix design proportions.

Table 2-2: Typical mix design of ECC material (Li, 2003)

\begin{tabular}{|c|c|c|c|c|c|}
\hline Cement & Water & Sand & Fly Ash & (HRWRA) & Fiber (Vol. \%) \\
\hline 1 & 0.58 & 0.8 & 1.2 & 0.013 & 2.00 \\
\hline
\end{tabular}

-High range water reducing admixture (HRWRA); all ingredients proportion by weight except for fiber

ECC is composed of fine aggregate, water, cement, sand, typically polyvinyl alcohol fiber (PVA), and admixture (Table 2-2). It has very good ductile behavior due to absence of course aggregate. ECC has low w/c ratio and sand/cement ratio of 0.5 or lower. Normally, $2 \%$ or less by volume of fiber is adequate for ECC mix $(\mathrm{Li}, 1998)$ Table 2-3 shows the ECC mixing sequence and mixing time. 
Table 2-3:Material charging sequence into ready-mix trucks (Li, 2007)

\begin{tabular}{|c|c|c|}
\hline $\begin{array}{l}\text { Activity } \\
\text { serial } \\
\text { no. }\end{array}$ & Activity & $\begin{array}{l}\text { Elapsed } \\
\text { time } \\
\text { (min) }\end{array}$ \\
\hline 1 & Apply all sand & 2 \\
\hline 2 & $\begin{array}{l}\text { Apply approximately } 90-95 \% \text { of mixing water, all HRWR, all } \\
\text { hydration stabilizer }\end{array}$ & 2 \\
\hline 3 & Apply all fly ash & 2 \\
\hline 4 & Apply cement & 2 \\
\hline 5 & Apply residual mixing water to shower drum fins & 4 \\
\hline 6 & Mixture at high RPM for 5 min or until materials is homogenous & 5 \\
\hline 7 & Charge fiber & 2 \\
\hline 8 & Mix at high RPM for 5 min or until materials is homogenous & 5 \\
\hline Total & & 24 \\
\hline
\end{tabular}

Comprehensive research has been conducted to develop green ECCs with self-healing capability through incorporating different types and sizes of local aggregates (silica sand, mortar sand or crushed sand), supplementary cementing materials (SCMs) such as fly ash, slag, glass powder, volcanic ash, MgO etc. and bacterial agents (Hossain et al. 2016; Hossain \& Anwar 2014; Hossain 2015; Sherir 2012; Sherir et al. 2016; Sherir et al. 2017; Bhaskar 2016; Siad et al. 2017).

\subsubsection{Applications of ECC}

Mishra (1995) investigated the use of ECC with poly ethylene (PE) fiber in the hinging zone of a beam-column connection. It used repetitive and a found hysteretic loops in PE-ECC connection with sustain load cycle, energy absorption of PE-ECC specimen 2.8 times more than the RC specimen and cracking behavior was similar to both specimens. This investigation recommends the potential of ECC to assist as a high safety in important structural systems which may be exposed to severe earthquake loads.

Li et al. (2000) investigated the practice of a super ductile fiber reinforced cementitious composite for restoration and retrofit of concrete structures. Three repair materials used for this investigation such as normal concrete, ECC, FRC. Four-point load used to observe notch width below the control specimens. The result showed that concrete repair material load drops immediately following the kink out and specimen broken into two pieces. Normal concrete and fiber reinforced concrete (FRC) spalling variation were very small. For ECC repair specimen, a sequence of interface crack extension, kink-out, kink-crack detention and new interface kink crack exposed due to increasing applied load. Finally, ECC had shown the flexure crack and strong 
bridging action of ECC and cement mortar together induced a king-crack trapping phenomenon that enhanced the ECC repair material property. Figure 2-7 shows flexure behaviors of PE-ECC slab.

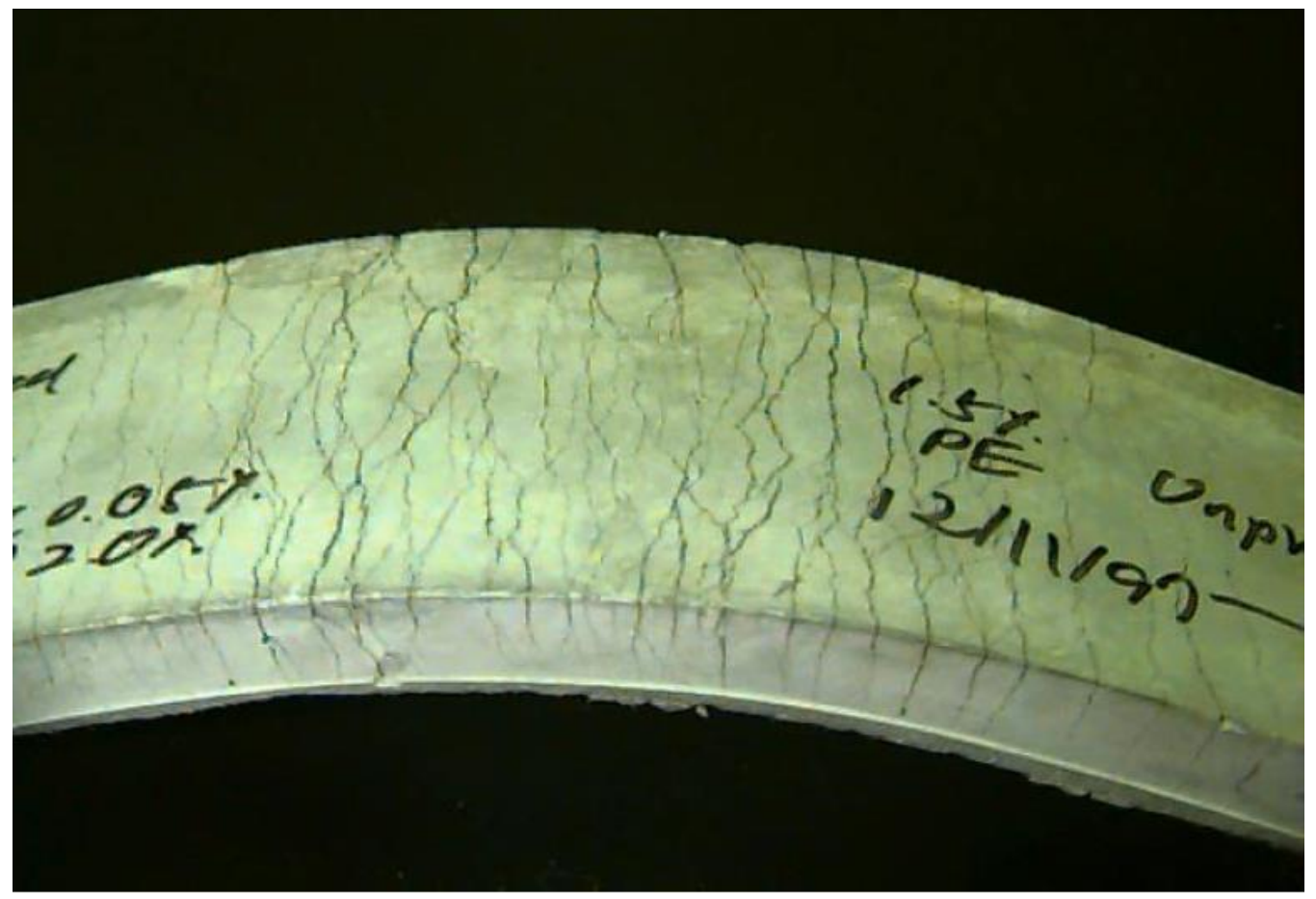

Figure 2-7: Flexural Behavior of a PE-ECC (reinforced with high modulus polyethylene fibers) $(\mathrm{Li}, 1995)$

Zhang et al. (2015) explored the application of PP-ECC (using poly propylene fiber) in beam-column joint connections of rigid-framed railway bridges to reduce transverse reinforcements. For this investigation three $1 / 6^{\text {th }}$ scale beam-column joint was constructed and tested, A sample was developed similar to existing railway bridges in Japan but without transverse rebar in the joint. Another two specimens were prepared with reducing the number of ties and stirrups in beam-column joint. The experimental investigation revealed that at the shear span to depth ratio $(\mathrm{a} / \mathrm{d})$ of 2.8 , shear capacity increase by $20.6 \%$ and $107.6 \%$, respectively with and without stirrups using PP-ECC instead of normal concrete. PP-ECC could be used instead of transverse reinforcement and it improved workability significantly. In addition, PP-ECC acted as shear reinforcement to transmit the applied load. Furthermore, PP-ECC increased the ductility and absorbed more energy. 
Salahuddin \& Mohamad (2014) investigated uses of ECC in interior beam-column connections for enhanced seismic resistance. In this study, nine sample used (one-third scale) in type 2 interior join in seismic zone 3 and tested under cyclic loading and seismic excitation. The samples were designed as per ACI 318 (2008). All column dimensions were $185 \mathrm{~mm}$ x $185 \mathrm{~mm}$ and height of $1200 \mathrm{~mm}$ and dimension of beams were $150 \mathrm{~mm} \times 200 \mathrm{~mm}$ and length $2000 \mathrm{~m}$.

ECC showed the greater ability to resist and survive reverse cycle load and had greater energy dissipation capacity. In addition, ECC exhibited multi-cracking narrow homogeneous cracks all over the surface of the plastic zone and joint core. ECC also enhanced structural integrity at high drift ratio and joint shear stress capacity. ECC could be applicable in a high potential area where energy absorption structure such as a short column, dampers, joints for steel elements, and connections of steel and RC structure. Where 3-D loading impact on the structure, ECC structure would take advantage to absorb isotropic energy; for example, pavements, bridge decks, and blast resisting building (Li V. C., 1998).

\subsection{High-Performance Concrete (HPC)}

HPC is not basically different from the concrete used in the past, although it usually contains supplementary cementing materials (SCMs) such as ground granulated blast-furnace slag, fly ash, and silica fume as well as superplasticizer. The content of cementitious material is high and the water/cement ratio is low; the maximum size of aggregate is small (Neville \& Aitcin, 1998). Ordinary Portland cement is must be compatible with a given superplasticizer. Mix design of HPC is more complicated because it includes more materials, like superplasticizer and supplementary cementitious materials as well as to be designed to ensure maintaining a low water/binder ratio with adequate workability (Zain, Islam, \& Basri, 2005). Actually, HPC evolved gradually over the last decade, mainly by the production of concrete with higher and higher strengths: 80, 90, 100, $120 \mathrm{MPa}$, and sometimes even higher. Nowadays, in some parts of the world, $140 \mathrm{MPa}$ can be

routinely produced (Neville \& Aitcin, 1998). But high-performance concrete is not the same as high strength concrete. In general, the cement content in HPC mixes is found to be in the range of $218-500 \mathrm{~kg} / \mathrm{m}^{3}$ with water to binder (w/b) ratio as 0.28 to 0.45 and 0.3 to 0.35 as the most preferred range (Ajdukiewicz \& Akliszczewicz, 2002). 


\subsection{Lightweight Aggregate (LWA)}

\subsubsection{Introduction of Lightweight Aggregate}

Lightweight aggregate (LWA) is used in the production of lightweight concrete products such as concrete block, structural concrete, and pavement. The LWA has properties like natural aggregate, but is less dense and therefore yields a lighter concrete product. LWA typically formed as a result of the thermal process. This process may be natural such as volcanic action or artificial applied to produce aggregate. Natural lightweight aggregates like pumice and scoria are available in volcanic areas all over the world where the volcano is available. The pore structure of LWA is formed due to gas bubble trapped in molten lava while cooling of ejected lava (Hossain, 2004).

\subsubsection{Type of lightweight aggregates}

The Concrete Society(CS) of United Kingdom mentioned that the most commonly used LWA is Lytag in U.K. (CS, 2016). Also, there are other types of LWAs made from a variety of raw materials as mentioned in Table 2-4.

Table 2-4:Aggregate type and dry density (CS, 2016).

\begin{tabular}{|l|l|l|}
\hline Lightweight aggregate type & Trade name & Dry density kg/m ${ }^{3}$ \\
\hline Furnace clinker & & $720-1040$ \\
\hline Processed fly ash/ pulverized fuel ash (PFA) & Lytag & $770-960$ \\
\hline Blast furnace slag & & $670-920$ \\
\hline Expanded clay, shale and slate & Aglite, Leca, Solite & $320-960$ \\
\hline Pumice & & $480-880$ \\
\hline Pelletized expanded slag & Pellite & $800-1000$ \\
\hline Wood and plastic particles & & $320-480$ \\
\hline Expanded vermiculite & & $60-160$ \\
\hline
\end{tabular}

There are two main categories of lightweight available, natural lightweight aggregate and manufactured lightweight aggregates. Volcanic materials such as pumice, scoria, volcanic cinders, tuff, and diatomite are the natural lightweight aggregates. Manufactured lightweight aggregates include expanded shale, clay, slate, fly ash, and expanded slag. These LWAs show the consistency mechanical properties of the hardened LWC (Harding, 1995). Figure 2-8 shows Lytag aggregate and internal pore structure. 

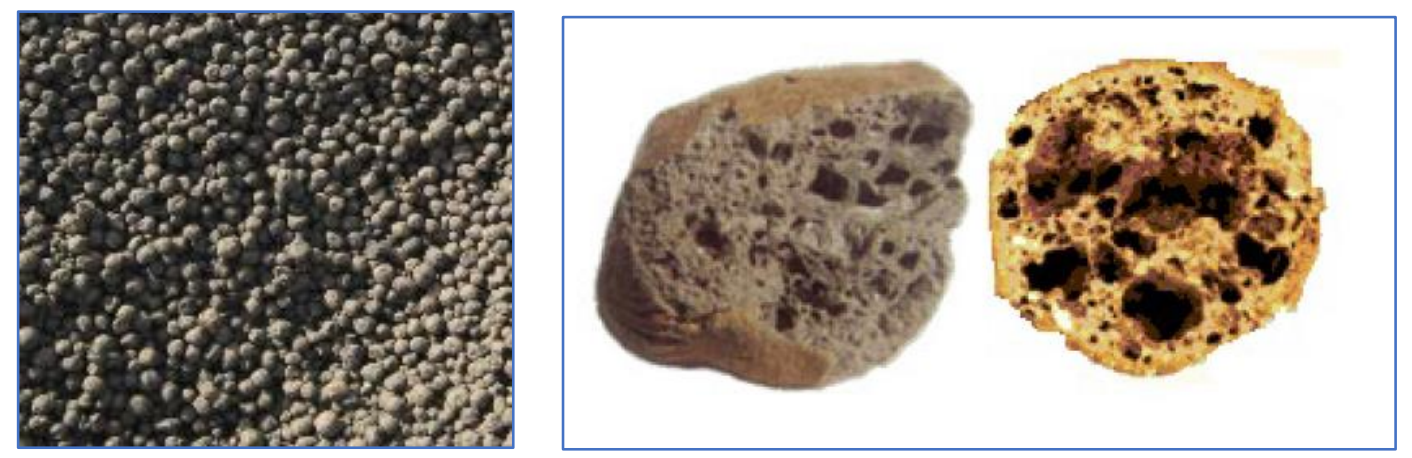

Figure 2-8: Lytag aggregate and internal pore structure (Lotfy, 2012).

\subsubsection{Physical Properties of lightweight aggregates}

ASTM established standard for physical properties for lightweight aggregate that is clay lumps and friable particle shall not exceed $2 \%$ by dry mass. Bulk density and compressive strength should be as per Table 2-5 and Table 2-6, respectively.

Table 2-5: Maximum dry loose bulk density of LWA for Structural Concrete (ASTM C330, 2014)

\begin{tabular}{lll}
\hline Size Designation & Maximum Dry Loose Bulk \\
& Density kg/m $\mathrm{m}^{3}$ & \\
\hline Fine aggregate & 1120 \\
Coarse aggregate & 880 \\
Combine fine and coarse aggregate & 1004 & \\
\hline
\end{tabular}

Table 2-6: Compressive Strength and Splitting Tensile Strength Requirements (ASTM C330, 2014)

\begin{tabular}{lll}
\hline Density max, $\mathrm{kg} / \mathrm{m}^{3}$ & $\begin{array}{l}\text { Average 28-day } \\
\text { Tensile Strength min, } \mathrm{MPa}\end{array}$ & $\begin{array}{l}\text { Splitting } \\
\text { Average 28-day Compressive } \\
\text { Strength, min, MPa }\end{array}$ \\
\hline All Lightweight Aggregate & & 28 \\
1760 & 2.2 & 21 \\
1680 & 2.1 & 17 \\
1600 & 2.0 & 28 \\
\hline Combination of Normal Weight and Lightweight Aggregate \\
1840 & 2.3 & 21 \\
1760 & 2.1 & 17 \\
1680 & 2.1 & \\
\hline
\end{tabular}

\subsubsection{Lightweight Concrete}

Lightweight concrete for physical applications refers to concrete that is made with LWAs compatible to ASTM C 330, has a compressive strength in surplus of $17.23 \mathrm{MPa}$ at 28 days when 
tested based on ASTM C 330, and has an air dry unit weight not in excess of $1840 \mathrm{~kg} / \mathrm{m}^{3}$ as determined by ASTM C 330. Figure 2-9 shows the classification of lightweight concrete and types of aggregates used (Harding 1995).

\subsection{Lightweight Self- Consolidating Concrete (LWSCC)}

\subsubsection{Introduction of LWSCC and mix design}

In the recent era, the utilization of mineral and chemical admixtures in concrete technology governed by variations in the invention and mix design which has led to making the concrete stronger and more durable. Lightweight concrete (LWC) reduces the dead load of the structure, whereas self-compacting concrete (SCC) easy the pouring and removes construction problems. LWSCC combines all the best properties of the lightweight concrete (LWC) with the best properties of the SCC (Behnam \& Shami, 2016).

Lightweight aggregates absorb and hold more moisture than ordinary aggregates. Because of its greater porosity, extra care is required when designing the LWSCC mix and when dosing the mix water, (Lotfy A. , 2012). In fact, lightweight aggregates (LWA) absorb water for hours, days and

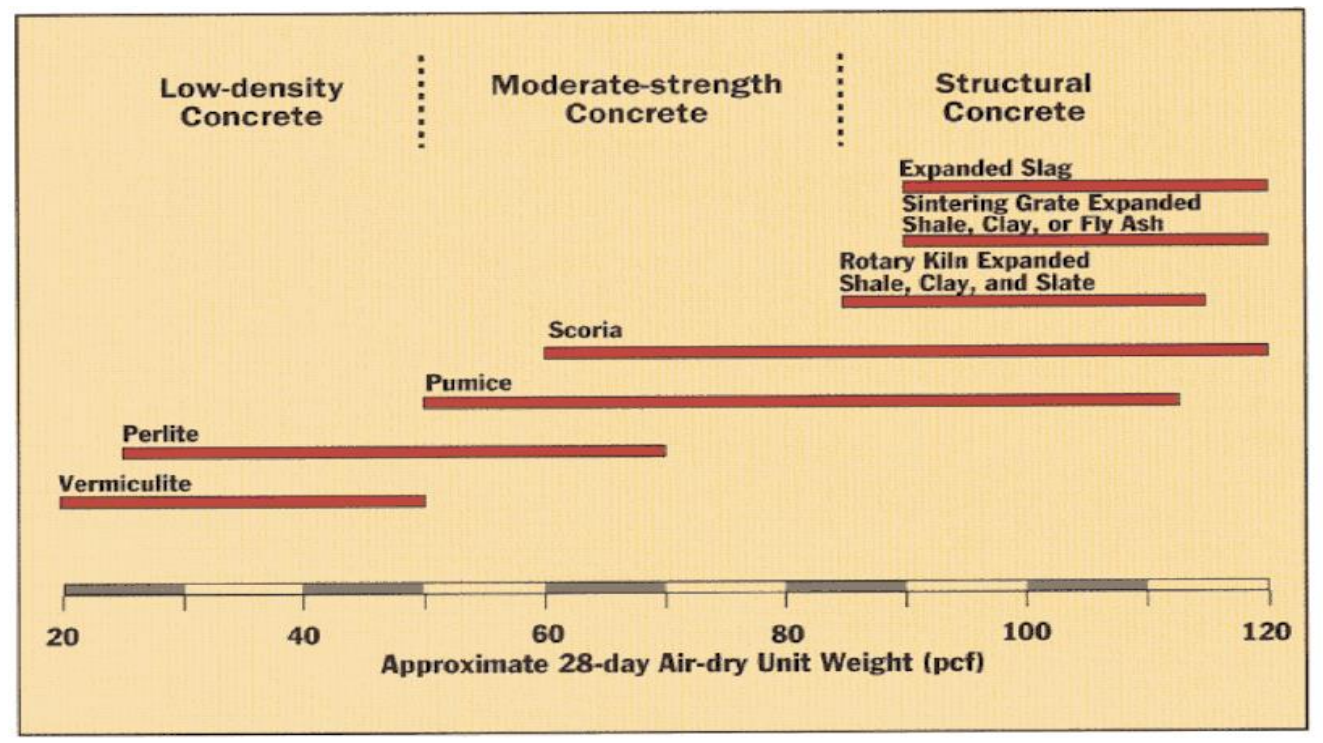

Figure 2-9: Classification of lightweight concrete and types of aggregates used (Harding 1995)

even weeks after first being wetted. Though the surface texture and aggregate shape may have an effect on the workability, rougher - angular particles result in a mix that has lower workability than smooth - rounder particles. Most lightweight aggregates weigh about 0.50 to 0.66 the weight of normal aggregate. On average, $1 \mathrm{~kg}$ of gravel can be replaced with slightly more than $1 / 2 \mathrm{~kg}$ of LWC. The volume of aggregate stays the similar, but the weight is reduced. (Mangum, 2006). 
LWSCC design methods are similar those used for SCC. Numerous design methods developed based on scientific theories or experiential expressions derived from experiences have been proposed for LWSCC.

In general, LWSCC design methods fall into the following two categories: 1) Combination of highrange water-reducing admixture and high content of mineral powders; 2) Combination of highrange water-reducing admixture and viscosity-modifying admixture (VMA) with or without defoamer agent. In generally, the compressive strength of LWSCC is consider a important parameter to estimation its other mechanical properties. Despite of available studies on the advantages of LWSCC associated with its high performance in the fresh state, nonetheless few studies regarding the expected hardened properties for mechanical responses like compressive strength. LWSCC is extremely sensitive to its mix component, properties and their proportions, hence it requires increased quality control. The typical characteristics of LWSCC mix proportions, and its fresh properties have significant effects on toughened properties like strength, dimensional constancy and durability (Koehler \& Fowler, 2007). For example, the compressive strength of LWSCC depends on the aggregate type and the w/c and water to total powder $(w / b)$. Packing density concept is a technique of concrete mix design that has been successfully utilized in LWSCC by determining the best cement to aggregates packing voids ratio (Lotfy et al.,2015).The objective of LWSCC mix design are to minimize the voids volumes related to the coarse aggregate, maximize the density of the cementitious materials, minimize the water to cement ratio and (d) optimize the flowability requirements of the fresh concrete (Kaffetzakis \& Papanicolaou, 2012). Extensive research has been conducted at Ryerson University to develop LWSCC by incorporating furnace slag, expanded clay and expanded shale aggregates. The fresh state, mechanical, transport and durability properties have been extensively evaluated (Lotfy et al. 2016a, b).

\subsubsection{Application of LWSCC}

In spite of different codes of practice for LWC mix design and publications about SCC in the literature, there is no reference and methodical draft about LWSCC mix design and its application (Lotfy et al. 2016a,b). Despite the complicated nature, LWSCC use is highly growing in different parts of the world due to expected advantages in terms of cost efficiency and less construction time. Japan used the first application of LWSCC for the construction of a cable-stayed bridge's main girder in 1922. In the last few years, LWSCC has been used in a few structural applications, such as precast stadium benches and bridges with $40 \mathrm{~m}$ long span (Hubertova \& Hela, 2007). The 
LWSCC with pozzolans or slag cement be considered in beams when there are long spans, poor soil conditions, and congested reinforcement, such as beams with spans reaching up to $20 \mathrm{~m}$ (Dymond, 2007). It is also suggested that lightweight concretes be considered for reducing deck cracking (Ozyildirim, 2014).

\subsection{Role of fiber in reinforced concrete}

\subsubsection{Polyvinyl alcohol (PVA) fiber}

Fiber in concrete increases its structural integrity. Fiber reinforced concrete (FRC) contains short discrete fibers that are uniformly distributed and randomly oriented. The most common type of fiber is Polyvinyl Alcohol (PVA) fibers which is used for production of ECC.
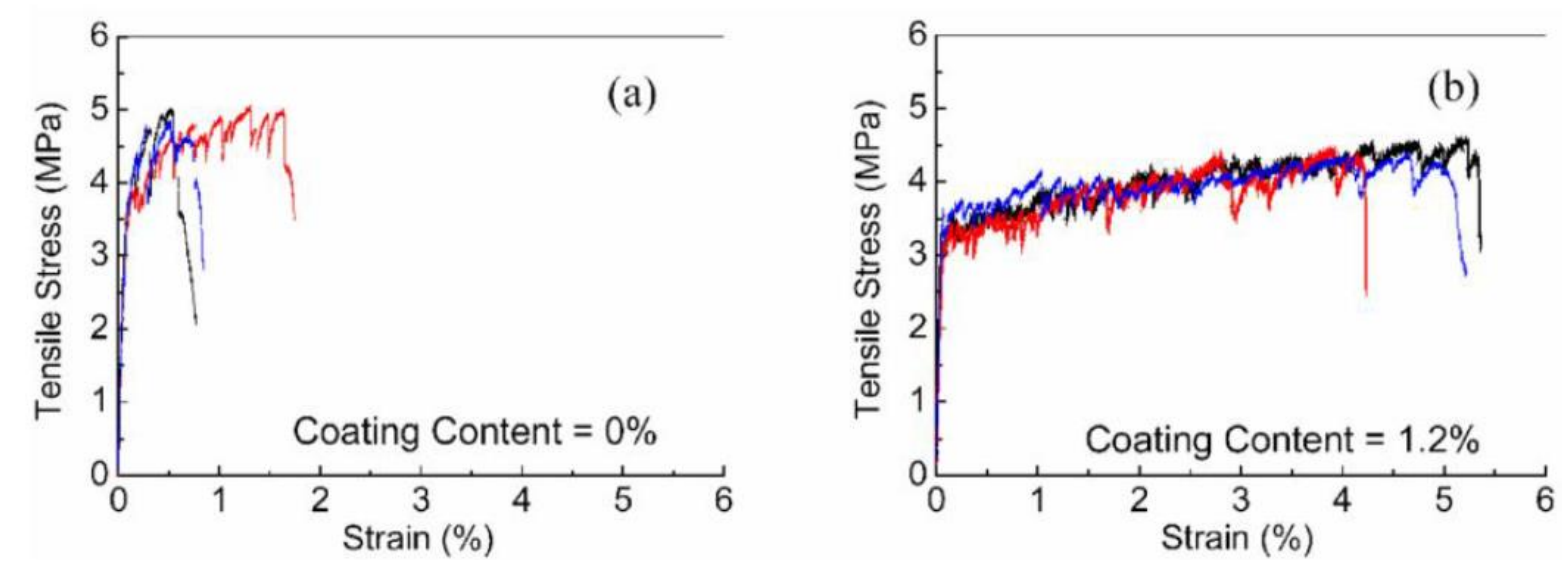

Figure 2-10: Ultimate tensile strain of ECC between (a) uncoated and (b) Coated fiber ( $\mathrm{Li}$, et al., 2003)

The short, discontinuous PVA fiber with high tensile strength and modulus of elasticity enhance the concrete ductility while carries tensile stresses after the first crack formation through the fiber bridging characteristic. The fiber bridging transfers the stresses transversely the crack for maintaining the low crack widths (JCI-DFRCC Committee, 2003). The surface of the PVA fiber is oil coated (by $1.2 \%$ of mass) to tailor the interfacial properties among the fiber and matrix for strain hardening performance (Li., 2002). The oil coating reduces the interfacial bonding, while increasing the tensile strain capacity of the ECC mix, therefore under tensile stresses; the fiber tends to be ruptured rather than pull out like other FRC (Li et al., 2002). Figure 2-10 shows the difference between coated and uncoated fibers and their effect on the stress strain curves of ECC. Table 2.7 summarizes the essential properties of the PVA fiber for maintaining the strain hardening characteristic of the ECC mix. 
Table 2-7: Geometrical and mechanical properties of PVA fiber

\begin{tabular}{|l|l|l|l|}
\hline Diameter $(\mu \mathrm{m})$ & Length $(\mathrm{mm})$ & $\begin{array}{l}\text { Nominal strength } \\
(\mathrm{MPa})\end{array}$ & $\begin{array}{l}\text { Modulus of elasticity } \\
(\mathrm{GPa})\end{array}$ \\
\hline 39 & $6-12$ & 1620 & 2.8 \\
\hline
\end{tabular}

\subsubsection{Crumb rubber fiber}

Recently, substantial research has been conducted on the application of waste rubber in the concrete structure as an alternative for conventional coarse and fine aggregates. Crumb rubber fiber is an eco-friendly, environmental alternative to the accumulated millions of waste tires (Pelisser et al., 2001). Involving crumb rubber in concrete, certainly, contributes not only to limiting the serious environmental problems that result from the dumping of worn-out tires by burning or piling up in landfills, but it also reduces the consumption of natural conventional aggregates. Accordingly, the waste rubber involving in the construction industry helps to promote the development of green buildings and implement the concept of sustainable production (Su et al., 2015). Nevertheless, some of these proposals are economically or environmentally unviable. Crumb rubber is black with a sand like texture and has been made from recycled tires by grinding and has a specific gravity is 0.9 (Karahan et al., 2012).

A large number of applications have been described that the recycle of scrap and tyres has become a viable solution for sustainable construction since an early study by Eldin and Senouci (1993). Many scholars have confirmed that there is a reduction in compressive strength, and an increase in ductility with the increasing proportion of rubber phase in the mixture (Bignozzi \& Sandrolini, 2006). Few research studies have been conducted to investigate the effect of the size of crumbed rubber fiber on concrete properties such as workability, durability and strength as indicated by the literature review (Albano et al., 2005; Ali, 1993).

Li et al. (2009) described that using rubber particle sizes between 0.25 and $1 \mathrm{~mm}$ has minimum effect on the tensile splitting strength and finer rubber was mainly helpful for reducing the tensile splitting strength loss. As results partially disagree with the discoveries of Albano et al. (2005) who found that a reduction in the rubber particle size from $0.59 \mathrm{~mm}$ to $0.29 \mathrm{~mm}$ lead to lesser workability at the fresh stage and the weaker compressive and tensile splitting strengths at the dry stage. 


\subsubsection{High Density poly ethylene (HDPE) fiber}

Fibre reinforced concrete (FRC) has numerous benefits, for example, reduced shrinkage, increased flexural ductility, high tensile fatigue strength, high fracture energy and heat resistance to the explosive spalling at high temperatures. FRC involving in variety of structures from foundation slabs, industrial floors and pavements to the bridges and tunnels (Pešic'et al., 2016). Current innovation in the technology of concrete and demands for delivering more eco-friendly and sustainable projects gave rise to the idea of disposing post-consumer waste polymers into structural concrete. The high-density polyethylene (HDPE) is one of the recycle polymer whose physical and chemical properties are most similar to Polypropylene (PP). In addition, HDPE has a low bond strength between HDPE and concrete but, with textured or ribbed surfaces had shown (Kobayashi $\&$ Cho, 1981) to increase ductility and the post cracking flexural toughness of concrete achieving almost identical mechanical properties to the equivalent concretes reinforced with PP and highmodulus polyethylene fibres (Soroushian, Khan, \& Hsu, 1992 ). Nevertheless, previously HDPE fiber did not lead to the wider acceptance in construction. Later, Bhavi et al. (2012) developed design mix with $0.2-1.0 \%$ volume fractions of HDPE fibers cut from waste plastic waste. Their results from the strength tests indicated that the use of HDPE fibres in a volume of $0.6 \%$ can enhance the compressive, tensile, flexural and impact strengths of concrete by up to $15 \%, 23 \%$, $22 \%$ and $200 \%$, respectively (with only modest gains from increasing the fibre volumes to $0.8 \%$ and $1.0 \%$ ). Accordingly, a need for more research on the properties and benefits of using HDPE FRC has been emphasized by Yin et al. (2015) in the most recent review on the subject of concrete reinforced with polymer fibers. HDPE based new economical concrete can be created due to the large quantities of readily available post-consumer waste such as disposed pipes, food containers, toys, computer cases and car parts. The recycled HDPE fibers could be most economically produced from these stocks through one of the technologically established extrusion processes (Peackock, 2000).

\subsection{Related research on corrosion study of reinforce concrete beams}

Shanmugam et al. (2013) conducted research to determine the effects of corrosion on reinforced concrete beams with silica fume and polypropylene fiber. They found that the corrosion on reinforced concrete beam can be reduced using silica fume and polypropylene fiber. Twenty four beam specimens $(100 \mathrm{~mm} \times 150 \mathrm{~mm} \times 1000 \mathrm{~m})$ were built for this experiment with epoxy coated and non-epoxy coated rebar using M35 concrete with ordinary Portland cement (OPC), $5 \%$ silica 
fume and polypropylene fiber of $0.6 \%$ by weight of cement. Accelerated chloride induced corrosion test was performed with stress and unstressed condition. Load carrying capacity of unstressed specimens with coated rebar was higher than stressed specimens with uncoated rebar subjected to corrosion. The combination of silica fume, fiber, and coated rebar showed the good corrosion with $71.17 \%$ lower rebar mass loss than that of uncoated rebar.

An experimental study on corrosion behavior of RC beams having different concrete strength (Wang, Li, \& Yi, 2015) claimed that load capacity and rigidity of corroded beam increased with the increase of concrete strength. Fourteen test specimens of dimensions $120 \mathrm{~mm}$ x $200 \mathrm{~mm}$ x $1700 \mathrm{~mm}$ were built with concrete of different strengths (C20, C25, C30 and C35). Tension rebars of these beam specimens were corroded by using accelerated corrosion technique and then tested under fatigue and monotonic loading. Reinforced beams were vastly affected due to corrosion in terms of fatigue capacity which also decreased the ultimate strength. Corroded RC beams showed higher deflection than non-corroded ones under the same load cycle.

Hossain (2004) investigated the chloride-induced corrosion of reinforcement in beams made of volcanic ash (VA) and pumice based blended concrete with different contents of VA and VPP (from 0 to 20\%). X-ray diffraction analysis, electromechanical and electrochemical testing and physical examination were conducted to monitor corrosion behaviors for an extended period of 650 days. VA and VPP blended concretes performed better in resisting reinforcing bar corrosion and the corrosion rate of reinforcing bar was found lower in VA and VPP based concrete than the normal concrete. The addition of VA and VPP exhibited better corrosion resistance than increasing cement content while the cement-water ratio is constant.

Shear behavior of RC beams with corrosion damaged partial length were investigated (Wang et al., 2011). Fourteen RC beams including 8 corroded, 4 partially unbonded and 2 having non-corroded length were tested at different corrosion levels within the shear span, The beams having dimensions of $150 \mathrm{~mm}$ x 180mm x 1800mm (support to support distance of $1200 \mathrm{~mm}$ ) made of $20 \mathrm{M}$ normal concrete had 2@6 mm bar at the top, 3@16 mm bar at the bottom and 6mm stirrups. Accelerated corrosion test performed was in one shear span in each beam then loading test completed. Ductile failure mode was found in the shear span for the control beam. The load carrying capacity, stiffness, and ductility were significantly reduced due to corrosion damage in partial length. All test beam was failed in shear failure where corrosion damaged was very high. 
Gowripalan and Mohamed (1998) conducted an experimental research to assess the usefulness of the use of (HPC) and galvanized steel in dropping reinforcement corrosion. Two normal strength concrete (NSC), and two high strength concrete (HSC) mixtures with 28-day compressive strengths of 30, $40 \mathrm{MPa}$ and 50 and $80 \mathrm{MPa}$ were used for this study. The RCPT was used to study the ion penetration and the results are compared with the results of enduring immersion tests in $4 \% \mathrm{NaCl}$ solution over a period of 1 year. No correlation between the results of these two tests could be established, and Half-cell potential measurements test were used to monitor the initiation and progress of corrosion. The $\mathrm{pH}$ of HPC pastes and mortars were observed to study the effect of silica fume on $\mathrm{p}^{\mathrm{H}}$ of concrete and corrosion initiation until 90 days. The results showed that HPC reduced chloride-ion penetration significantly. Silica fume at $10 \%$ replacement of cement reduced the $\mathrm{p}^{\mathrm{H}}$ level of concrete from 14.00 to 12.8 a period of 90 days. Galvanized steel can delay the chloride ion-induced corrosion. Use of HPC and galvanized steel together substantially delayed the chloride ion-induced corrosion.

Kayali and Zhu (2005) conducted research on high-strength reinforced silica fume-cement concrete slabs and conventional concrete slab with a compressive strength of $70 \mathrm{MPa}$ and $32 \mathrm{MPa}$ respectively to assess chloride diffusion and corrosion activity after partially submerged in a $2 \%$ chloride solution. Chloride diffusion in high-strength concrete was extremely low. On the other hand, chloride concentration found a high level beyond the depth of steel in 32MPa concrete. The corrosion potentials in normal concrete continued to gain larger negative values $(-350 \mathrm{mV})$ than the potential values(-200mV), (CSE) in high-strength concrete. Corrosion current thickness in 32 MPa concrete acquired active values in relatively short time, and in HSC, corrosion electricity density did not approach the threshold activation value. They claimed that the improvement in corrosion resisting property in high strength concrete continued after the first 28 days of curing while such development did not occur in the conventional concrete of $32 \mathrm{MPa}$, and the high strength concrete containing $10 \%$ silica fume possessed exceedingly high corrosion resistance.

Ismail and Ohtsu (2006) investigated the corrosion of reinforcing steel in concrete by using AC impedance. They used different conditions and chloride concentrations, and a laboratory study was conducted to estimate the corrosion rate of strengthening steel surrounded in ordinary Portland concrete (OPC) and high-performance concrete (HPC). They made one hundred and four OPC and HPC concrete cylinders embedded with a single reinforcing steel bar which were exposed to sodium chloride solution with $0 \%, 1 \%, 3 \%$ and $5 \%$ concentrations. The AC Impedance 
spectroscopy (IS) method was used to determine the corrosion rate of the reinforced concrete cylinders. The results confirmed that data obtained from AC impedance and can be used to calculate the corrosion rate of reinforcing steel. In addition, HPC specimens showed lower corrosion rates compared with OPC specimens. The lower W/C ratio and the use of silica fume resulted in a lower corrosion rate.

Montes et al. (2004) conducted experiments on the effects of calcium nitrite based corrosion inhibitor (CNI) and cracks width on the corrosion procedure of steel reinforcing bars in high-performance concrete. They used a different variable such as water to cement ratio, fly ash percent, CNI and cracked condition. They used the linear polarization resistance technique to measure the corrosion current density. Specimens concrete slabs were cast with steel reinforcement and a effective cover depth of $20 \mathrm{~mm}$. The slabs were exposed to a simulated sea environment with two cycles of wetting and drying per day. They found that CNI alone, in general, had no effect in decreasing corrosion and crack condition and crack width of the specimens strongly affected the corrosion process. The combination low w/c ratio, fly ash and CNI were effective in reducing cracking in concrete by decreasing cracking-corrosion interaction phenomenon.

Hussain et al. (2015) conducted research to find out the influence of high-performance reinforced concrete (HPRC) produced from different heavy and normal-weight aggregates on the corrosion rate of steel rebars. Three normal weight and two heavyweight coarse aggregate sources were used in this research. In addition, different w/c ratio, with and without silica fume and $2 \%$ and $5 \% \mathrm{NaCl}$ solution were used for this experiment. Prismatic specimens of $200 \times 100 \times 100 \mathrm{~mm}$ and including $10 \mathrm{~mm}$ bar were cast and cured. They demonstrated that the type of aggregate has substantial impact on the corrosion of HPRC. Based on the test results, it can be concluded that heavy coarse aggregate increases the corrosion rate than the normal weight aggregate.

Jaffer and Hansson (2008) conducted research on the effect of structural loading and the accompanying opening and width of the cracks on spreading chloride-induced rebar corrosion for reinforced ordinary Portland cement concrete and high-performance concrete. They tested all specimens under the static or cyclic three-point bending and exposed to the salt solution. They observed that the corrosion occurred at intersections of the rebar with cracks in the concrete. HPC was more protective than OPC concrete and the type of loading had less impact on corrosion than the type of concrete and contact environments. 
Hassan et al. (2008) investigated the shear resistance, bond characteristics, and corrosion performance of SCC beams compared to those of NC beams. Twenty RC beams without stirrups were tested under concentrated load in the mid-span until shear failure occurred. The four variables

of concrete type, coarse aggregate content, beam depth and longitudinal reinforcing steel ratio were subjected to testing. Beam depth varied from 150 to $750 \mathrm{~mm}$, while the shear span-to-depth ratio (a/d) was kept constant in all beams, and the two steel ratios of $1 \%$ and $2 \%$ were used for longitudinal reinforcement. The assessment between the SCC and NC beams was through the results of crack pattern, crack width, load at the first flexure/diagonal cracking, ultimate shear resistance, post-cracking shear resistance/ductility, load-deflection response, failure mode, first flexural cracking moment/load, and ultimate shear resistance, as well as simulated load deflection response. The corrosion of rebars used in SCC beams was investigated and compared to that used in NC beams. Bond stress was somewhat higher in SCC beams than in NC beams and the difference was more significant in the top bars and at 28 days of testing. The corrosion investigation in this research showed that SCC beams had better performance compared to their $\mathrm{NC}$ equivalents in terms of corrosion cracking, corrosion rate, half-cell potential, time of corrosion initiation, rebar mass loss and rebar diameter reduction. The SCC beams showed severe localized corrosion of stirrups and longitudinal rebars at the far end of the beam (away from the casting point), and that may have caused, in some cases, spalling of the concrete cover at the corners due to inadequate local compaction and distribution of concrete.

\subsection{Review conclusions}

Numerous research has been conducted on the mechanical and durability properties of SCC, ECC, and FRC. HPCs have been used in many structural applications over the last decades. Literature review confirmed the trend of using HPCs including SCC, LWSCC, FRLWSCC and ECC in structural applications. Although the structural performance and corrosion resistance of SCC and FRC are the subject matter of previous research studies, limited research has been conducted on ECC, LWSCC and FRLWSCC. Also, there has been limited research on the structural performance and corrosion resistance of composite beams made of combinations of ECC and SCC or ECC and LWSCC. The use of highly ductile ECC (having strain hardening and multimicrocracking characteristics) as layer and wrapping protecting the reinforcement in such composite beams can enhance corrosion resistance, structural performance and service life. Moreover, the lower corrosion resistance and structural performance (strength and stiffness) of 
comparatively weak and porous LWSCC based structures can be improved through making lightweight ECC+LWSCC composite structural elements. To date, no research studies have been conducted on the corrosion resistance of ECC-LWSCC composite structural elements which warrants the initiation of research on this aspect. The current study on the evaluation of corrosion resistance of SCC, LWSCC, FRLWSCC, ECC and composite beams made of SCC or LWSCC with ECC layer or wrapping and subsequent structural performance of corroded and uncorded beams is a timely initiative and will contribute to the existing knowledge of such technology. 


\section{CHAPTER 3 : EXPERIMENTAL PROGRAM}

\subsection{Introduction}

The experimental program involved a study on the corrosion performance of reinforced concrete beams. The investigation was focused on the corrosion of reinforcement in rectangular beam specimens (100mm width x 200mm depth x 1100mm length) made of full-depth Selfconsolidating Concrete (SCC), Lightweight Self-Consolidating concrete (LWSCC), Engineered Cementitious Composite (ECC) and three types of Fiber Reinforced Concretes (FRLWCs) (incorporating Polyvinyl Alcohol 'PVA', Crumb Rubber 'CR' and High Density Poly Ethylene 'HDPE' fibers) in addition to composite beams made of combinations of ECC-SCC and ECCLWSCC where ECC layer of different thickness was used at the bottom embedding main longitudinal reinforcement and part of shear reinforcement. Composite beam made of reinforced LWSCC core fully enclosed with ECC wrapping was also tested. The performance of corroded full-depth SCC/ECC/LWSCC/FRLWSCC and layered or fully enclosed composite beams was evaluated based on current measurement, half-cell potential measurement, mass loss, crack pattern, bar diameter degradation, strength loss, load deflection response and mode of failure compared to their non-corroded counterparts. This chapter describes the geometric dimensions of beam specimens, beam types, testing variables, properties of the materials, casting/curing of specimens, experimental setup with instrumentation, and test procedures.

\subsection{Beam geometry, beam types and reinforcement configurations}

A total of twenty-two beams with main and shear reinforcements were cast and tested. Two beams were cast for each type - one for non-corroded/control/fresh and the other for corroded testing. The beams were divided into three groups namely A (Full-depth SCC/ECC/ LWSCC beams), B (SCC-ECC, LWSCC-ECC composite beams- (layered with ECC, LWSCC cover /fully enclosed with ECC cover) and C (full-depth FRLWSCC beams). Table 3-1 shows the descriptions, dimensions, groups and designations of the beams. In addition, a letter of " $F$ " at the end of designation indicates the fresh/non-corroded and " $\mathrm{C}$ " indicates the corroded beams. For example, in Group A, fresh beam is coded as "A1-F", while its corroded counterpart is coded as "A1-C". A summary of beam groups and classifications is also shown in Figure 3-1. 
Table 3-1: Beams descriptions, classifications, designations and dimensions

\begin{tabular}{|c|c|c|c|}
\hline $\begin{array}{l}\text { Beam } \\
\text { No. }\end{array}$ & $\begin{array}{l}\text { Beam } \\
\text { Group }\end{array}$ & $\begin{array}{c}\text { Beam } \\
\text { Designation }\end{array}$ & $\begin{array}{c}\text { Beam descriptions } \\
\text { (effective span between supports- } 800 \mathrm{~mm} \text { ) }\end{array}$ \\
\hline 1 & \multirow{3}{*}{$\begin{array}{c}\text { A } \\
\text { Full-depth SCC/ } \\
\text { LWSCC/ECC } \\
\text { beams }\end{array}$} & $\begin{array}{c}\mathrm{A} 1 \\
(\mathrm{~A} 1-\mathrm{F}, \mathrm{A} 1-\mathrm{C})\end{array}$ & $\begin{array}{l}100 \mathrm{~mm} \text { width } \times 200 \mathrm{~mm} \text { height } \times 1100 \mathrm{~mm} \text { length of } \\
\text { SCC }\end{array}$ \\
\hline 2 & & $\begin{array}{c}\mathrm{A} 2 \\
(\mathrm{~A} 2-\mathrm{F}, \mathrm{A} 2-\mathrm{C})\end{array}$ & $\begin{array}{c}\text { 100mm width x 200mm height x 1100mm length of } \\
\text { LWSCC }\end{array}$ \\
\hline 3 & & $\begin{array}{c}\mathrm{A} 3 \\
(\mathrm{~A} 3-\mathrm{F}, \mathrm{A} 3-\mathrm{C})\end{array}$ & $\begin{array}{l}100 \mathrm{~mm} \text { width } \mathrm{x} 200 \mathrm{~mm} \text { height } \mathrm{x} 1100 \mathrm{~mm} \text { length of } \\
\text { ECC }\end{array}$ \\
\hline 4 & \multirow{5}{*}{$\begin{array}{c}\text { B } \\
\text { SCC-ECC, } \\
\text { LWSCC-ECC } \\
\text { composite beams } \\
\text { (layered with } \\
\text { ECC cover /fully } \\
\text { enclosed with } \\
\text { ECC cover) }\end{array}$} & $\begin{array}{c}\mathrm{B} 1 \\
(\mathrm{~B} 1-\mathrm{F}, \mathrm{B} 1-\mathrm{C})\end{array}$ & $\begin{array}{l}100 \mathrm{~mm} \text { height of ECC and } 125 \mathrm{~mm} \text { height of SCC x } \\
100 \mathrm{~mm} \text { width } \mathrm{x} 1100 \mathrm{~mm} \text { length }\end{array}$ \\
\hline 5 & & $\begin{array}{c}\mathrm{B} 2 \\
(\mathrm{~B} 2-\mathrm{F}, \mathrm{B} 2-\mathrm{C})\end{array}$ & $\begin{array}{l}100 \mathrm{~mm} \text { height of ECC and } 125 \mathrm{~mm} \text { height of LWSCC } \\
\text { x } 100 \mathrm{~mm} \text { width } \mathrm{x} 1100 \mathrm{~mm} \text { length }\end{array}$ \\
\hline 6 & & $\begin{array}{c}\text { B3 } \\
\text { (B3-F, B3-C) }\end{array}$ & $\begin{array}{l}14 \mathrm{~mm} \text { ECC cover and } 72 \mathrm{~mm} \times 172 \mathrm{~mm} \text { of LWSCC } \mathrm{x} \\
1100 \mathrm{~mm} \text { length }\end{array}$ \\
\hline 7 & & $\begin{array}{c}\text { B4 } \\
(\mathrm{B} 4-\mathrm{F}, \mathrm{B} 4-\mathrm{C})\end{array}$ & $\begin{array}{l}50 \mathrm{~mm} \text { height of ECC and } 150 \mathrm{~mm} \text { height of LWSCC } \mathrm{x} \\
100 \mathrm{~mm} \text { width } \mathrm{x} 1100 \mathrm{~mm} \text { length }\end{array}$ \\
\hline 8 & & $\begin{array}{c}\text { B5 } \\
\text { (B5-F, B5-C) }\end{array}$ & $\begin{array}{l}50 \mathrm{~mm} \text { height of ECC and } 150 \mathrm{~mm} \text { height of SCC x } \\
100 \mathrm{~mm} \text { width } \mathrm{x} 1100 \mathrm{~mm} \text { length }\end{array}$ \\
\hline 9 & \multirow{3}{*}{$\begin{array}{c}\text { C } \\
\text { Full-depth } \\
\text { FRLWSCC } \\
\text { beams }\end{array}$} & $\begin{array}{c}\mathrm{C} 1 \\
(\mathrm{C} 1-\mathrm{F}, \mathrm{C} 1-\mathrm{C})\end{array}$ & $\begin{array}{l}\text { 100mm width } \times 200 \mathrm{~mm} \text { height } \times 1100 \mathrm{~mm} \text { length of } \\
\text { LWSCC with } 0.25 \% \text { PVA fiber. }\end{array}$ \\
\hline 10 & & $\begin{array}{c}\mathrm{C} 2 \\
(\mathrm{C} 2-\mathrm{F}, \mathrm{C} 2-\mathrm{C}) \\
\end{array}$ & $\begin{array}{l}100 \mathrm{~mm} \text { width } \times 200 \mathrm{~mm} \text { height } \times 1100 \mathrm{~mm} \text { length of } \\
\text { LWSCC with } 1 \% \text { crumb rubber fiber. }\end{array}$ \\
\hline 11 & & $\begin{array}{c}\mathrm{C} 3 \\
(\mathrm{C} 3-\mathrm{F}, \mathrm{C} 3-\mathrm{C}) \\
\end{array}$ & $\begin{array}{l}\text { 100mm width x 200mm height x } 1100 \mathrm{~mm} \text { length of } \\
\text { LWSCC with } 1 \% \text { HDPE fiber. }\end{array}$ \\
\hline
\end{tabular}

Figure 3-2 shows typical dimensions and reinforcement details of beams while Figures 3-3 to 3-6 show the cross-sectional dimensions with reinforcement details for Group A, B and C beams. Table 3-2 summarizes dimensions and reinforcement details of the beam specimens. Similar reinforcement detail was used for all twenty-two beams - two 10 $\mathrm{mm}$ rebar at the bottom as main tensile reinforcement while two $6 \mathrm{~mm}$ rebars were used at the top as hanger bars for stirrups. Eight $6 \mathrm{~mm}$ stirrups were used for each beam. Stirrup details are shown in Figures 3-2 to 3-6. All beams were $100 \mathrm{~mm}$ in width (b), $200 \mathrm{~mm}$ in total depth and $1100 \mathrm{~mm}$ in total length (1) with an effective span of $800 \mathrm{~mm}$, except beams B1 and B2. Beams B1 and B2 were $100 \mathrm{~mm}$ in wide (b) and 225 $\mathrm{mm}$ in depth. The shear span to depth ratio (a/d) of all beams was kept constant at 1.53 to ensure shear failure instead bending failure. Also the main longitudinal reinforcement ratio $(\rho)$ was also kept constant at 1.14\% (Table 3.3). Effective depth (d), clear cover and depth of ECC layer/thickness of ECC wrapping in composite beams are presented in Table 3-1 and Figures 3-3 to 3-6. 


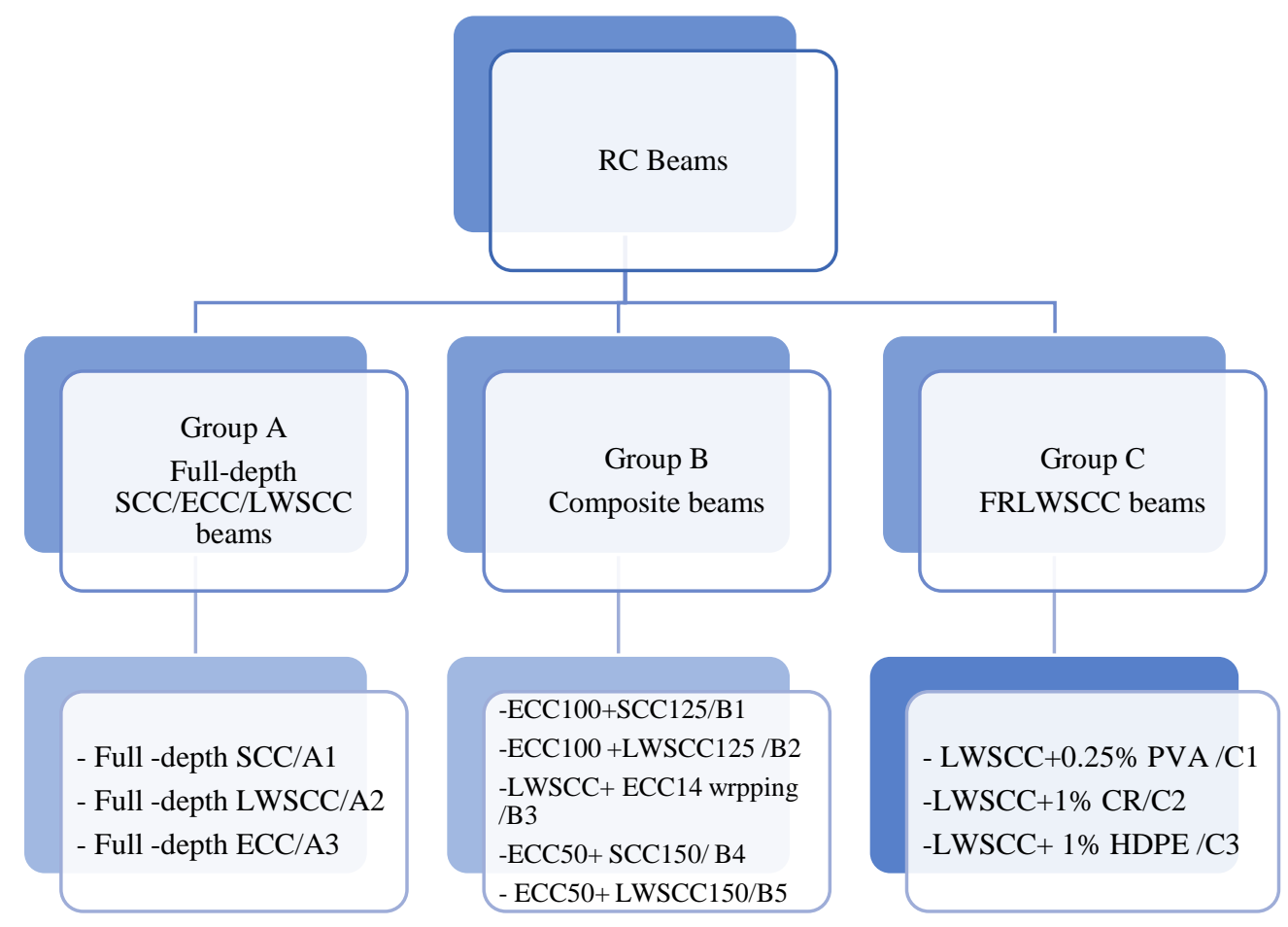

Figure 3-1: Beam group/Classification

Table 3-2: Geometric dimensions of beams and reinforcement configuration

\begin{tabular}{|c|c|c|c|c|c|}
\hline $\begin{array}{l}\text { Beam } \\
\text { code/designation }\end{array}$ & $\begin{array}{l}\text { Effective } \\
\text { depth } \\
\text { (d), mm }\end{array}$ & $\begin{array}{c}\text { Total } \\
\text { height } \\
\text { (h), mm }\end{array}$ & $\begin{array}{c}\text { Shear span } \\
\text { to depth } \\
\text { ratio, } \\
(\mathrm{a} / \mathrm{d})\end{array}$ & $\begin{array}{c}\text { Flexural } \\
\text { reinforcement } \\
\text { ratio, } \rho \\
\left(=\mathrm{A}_{\mathrm{s}} / \mathrm{b} * \mathrm{~d}\right) \%\end{array}$ & $\begin{array}{c}\text { Shear } \\
\text { reinforcement } \\
\text { spacing, } \\
\text { mm }\end{array}$ \\
\hline $\begin{array}{l}\text { All beam } \\
\text { Except (B1\&B2) }\end{array}$ & 175 & 200 & 1.53 & 1.14 & 133.5 \\
\hline B1, B2 & 175 & 225 & 1.53 & 1.14 & 133.5 \\
\hline
\end{tabular}




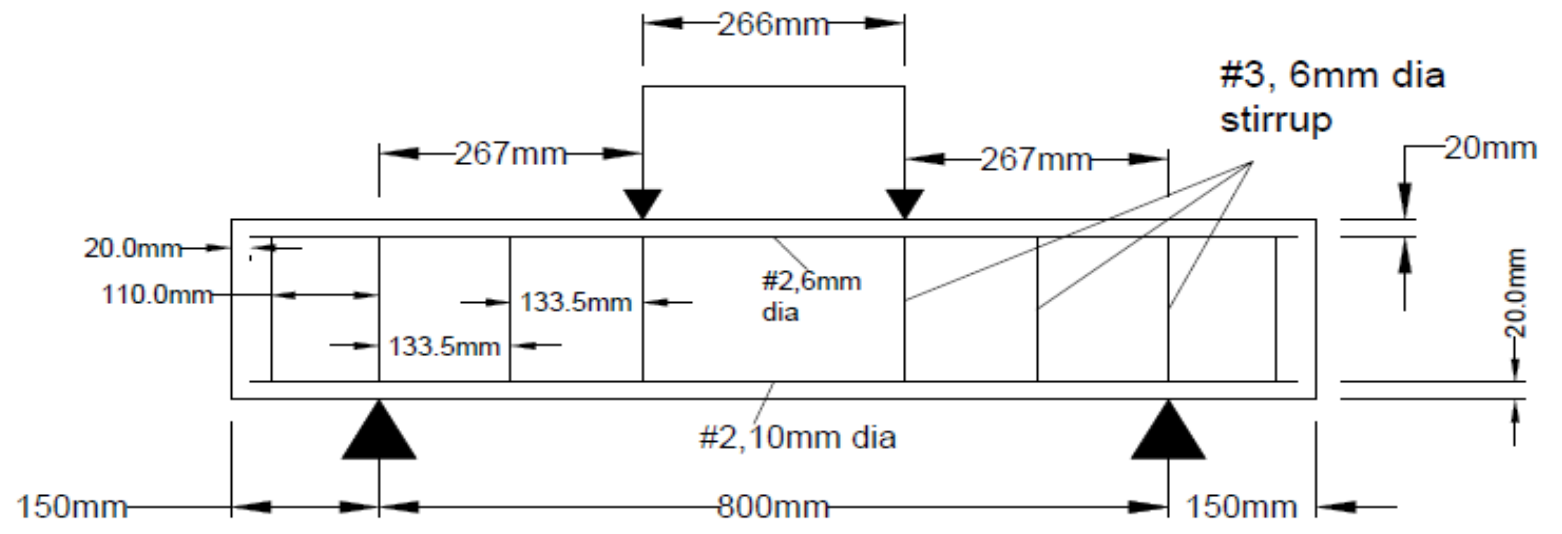

Figure 3-2: Beam reinforcement detail

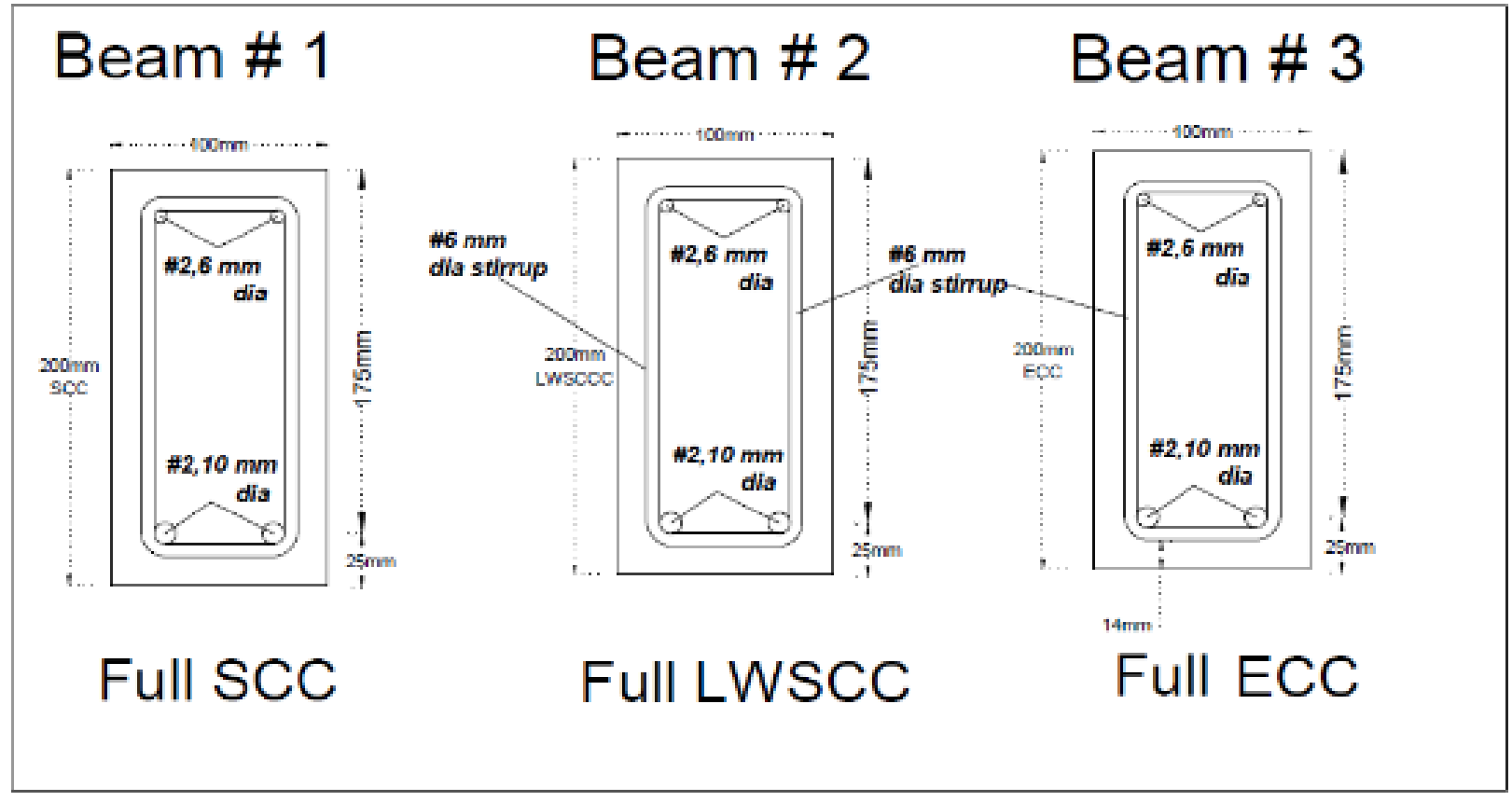

Figure 3-3: Cross-sectional details of full-depth/homogeneous beams showing reinforcement Group A (beams 1-3) 

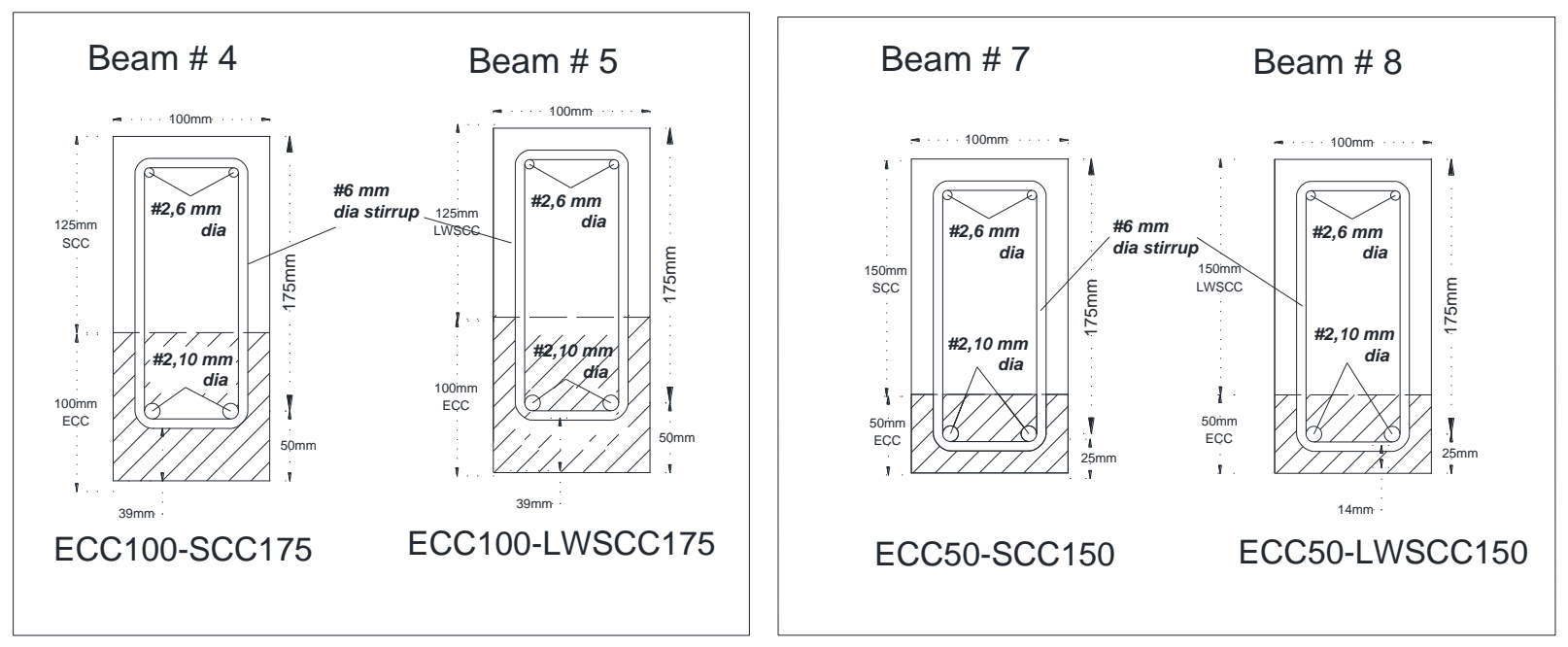

Figure 3-4: Cross-sectional details of composite beams with ECC layer showing reinforcement Group B (beams 4, 5, 7 and 8)

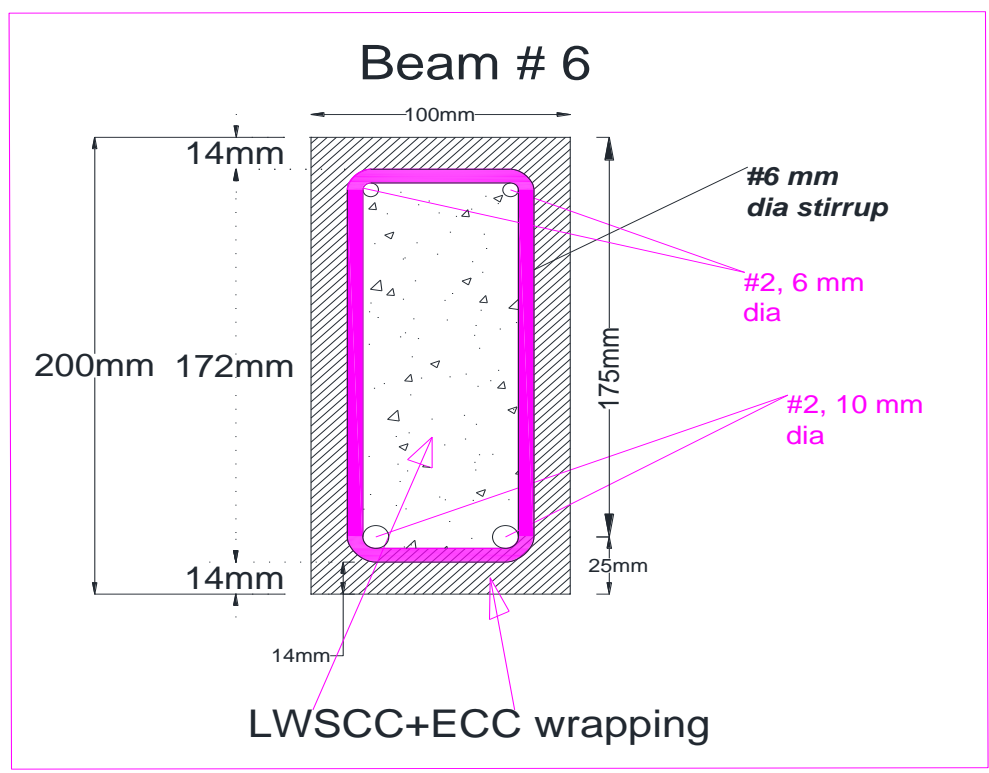

Figure 3-5: Cross-sectional details of composite beams with ECC wrapping showing reinforcement - Group B (beam 6) 


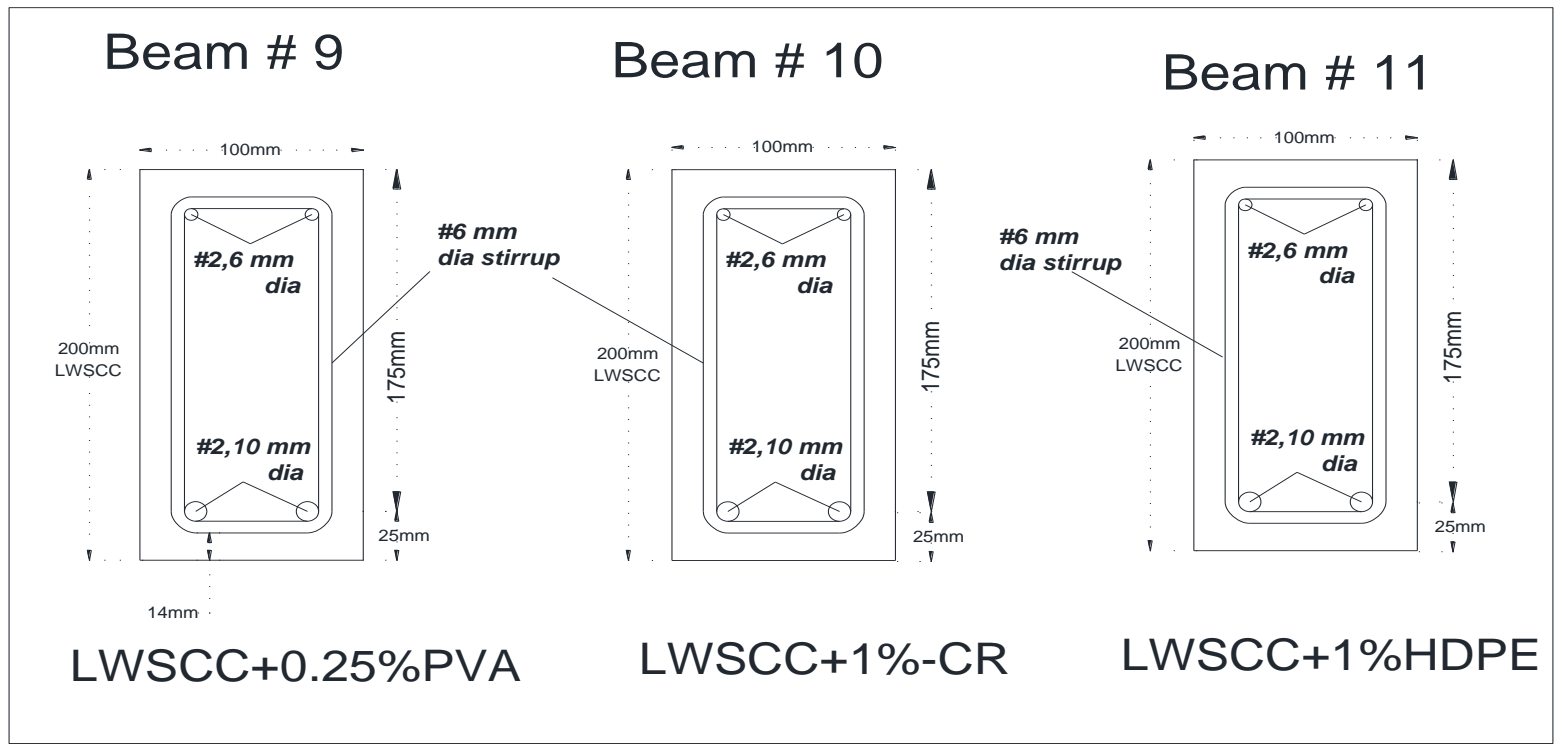

Figure 3-6: Cross-sectional details of FRLWSCC beams with PVA, CR and HDPE fibers showing reinforcement - Group C (beams 9-11)

\subsection{Materials, properties and concrete mix designs}

\subsubsection{Concrete materials, properties and mix design}

Mainly three types of concrete namely SCC, ECC, LWSCC and FRLWSCC (with PVA, CR, and HDPE fibers) were used to construct beam full-depth or composite beams. Mix designs of LWSCC, FRLWSCC and ECC are summarized in Table 3-3. CSA type 10 or ASTM type 1 cement with specific gravity 3.17 was used. Class F fly ash with specific gravity of 2.6, calcium content less than $8 \%$ and bulk density value $540 \sim 860 \mathrm{~kg} / \mathrm{m}^{3}$ was used. A dry density silica fume (SF) powder was used to enhance the concrete properties. Table 3-4 presents the chemical and physical properties of cementing materials. 
Table 3-3: Mix design of LWSCC and LWSCC with fiber

\begin{tabular}{|c|c|c|c|c|c|c|c|c|c|}
\hline $\begin{array}{l}\text { Concrete } \\
\text { Mix }\end{array}$ & $\mathrm{w} / \mathrm{b}$ & \begin{tabular}{l|} 
Type \\
10 \\
Cement
\end{tabular} & $\begin{array}{l}\text { Fly } \\
\text { Ash } \\
\text { (Class } \\
\text { F) }\end{array}$ & $\begin{array}{l}\text { Silica } \\
\text { Fume }\end{array}$ & Water & $\begin{array}{l}\text { Coarse } \\
\text { Aggregate }\end{array}$ & $\begin{array}{l}\text { Fine } \\
\text { Aggregate }\end{array}$ & $\begin{array}{l}\text { HRWRA } \\
\left(\mathrm{kg} / \mathrm{m}^{3}\right)\end{array}$ & $\begin{array}{l}\text { Fibre } \\
\left(\mathrm{kg} / \mathrm{m}^{3}\right)\end{array}$ \\
\hline \multicolumn{10}{|c|}{$\begin{array}{l}\text { LWSCC and FRLWSCC mixtures: w-water; b-binder; HRWRA- High Range Water Reducing } \\
\text { Admixture; Ratio of ingredient for the mixes are by mass; Ingredients per } 1 \text { part of cement }\end{array}$} \\
\hline LWSCC & 0.33 & \begin{tabular}{|l|l|}
1 &
\end{tabular} & 0.156 & 0.137 & 0.413 & 1.179 & 1.667 & 3.876 & - \\
\hline $\begin{array}{l}\text { FRLWSCC- } \\
\text { PVA (with } \\
0.25 \% \text { PVA) }\end{array}$ & 035 & 1 & 0.156 & 0.094 & 0.437 & 1.179 & 1.654 & 4.75 & 3.25 \\
\hline $\begin{array}{l}\text { FRLWSCC- } \\
\text { HDPE } \quad(1 \% \\
\text { HDPE })\end{array}$ & 0.35 & 1 & 0.156 & 0.094 & 0.47 & 1.179 & 1.614 & 4.75 & 9.6 \\
\hline $\begin{array}{l}\text { FRLWSCC- } \\
\text { CR }(1 \% \mathrm{CR})\end{array}$ & 0.35 & 1 & 0156 & 0.0934 & 0.437 & 1.179 & 1.614 & 475 & 9.0 \\
\hline \multirow{3}{*}{ Mix type } & \multicolumn{7}{|c|}{ ECC mixture } & & \\
\hline & \multicolumn{4}{|c|}{ Ingredients per 1 part of cement } & \multirow{2}{*}{$\begin{array}{l}\text { PVA } \\
\left(\mathrm{kg} / \mathrm{m}^{3}\right)\end{array}$} & \multirow{2}{*}{\multicolumn{2}{|c|}{$\begin{array}{l}\text { HRWRA } \\
\left(\mathrm{kg} / \mathrm{m}^{3}\right)\end{array}$}} & \multirow{2}{*}{\multicolumn{2}{|c|}{$\mathrm{w} / \mathrm{b}$}} \\
\hline & $\begin{array}{l}\text { Type } 10 \\
\text { Cement }\end{array}$ & \multicolumn{2}{|c|}{$\begin{array}{l}\text { Fly Ash } \\
\text { (class F) }\end{array}$} & $\begin{array}{l}\text { Silica } \\
\text { Sand }\end{array}$ & & & & & \\
\hline ECC & 1 & \multicolumn{2}{|c|}{1.2} & 0.80 & 26 & \multicolumn{2}{|l|}{5.4} & \multicolumn{2}{|l|}{0.27} \\
\hline
\end{tabular}

Table 3-4: Chemical and physical properties of cementing materials

\begin{tabular}{|l|l|l|l|}
\hline $\begin{array}{l}\text { Chemical } \\
\text { Composition }\end{array}$ & Cement & Fly ash & Silica Fume \\
\hline $\mathrm{SiO}_{2}(\%)$ & 19.6 & 46.7 & 95.21 \\
\hline $\mathrm{Al}_{2} \mathrm{O}_{3}(\%)$ & 4.9 & 22.8 & 0.21 \\
\hline $\mathrm{Fe}_{2} \mathrm{O}_{3}(\%)$ & 3.1 & 15.5 & 0.13 \\
\hline $\mathrm{CaO}(\%)$ & 61.4 & 5.8 & 0.23 \\
\hline $\mathrm{MgO}(\%)$ & 3.0 & - & - \\
\hline $\mathrm{SO}_{3}(\%)$ & 3.6 & 0.5 & 0.33 \\
\hline Alkalis as $\mathrm{Na}_{2} \mathrm{O}(\%)$ & 0.7 & 0.7 & 0.85 \\
\hline
\end{tabular}


The slag aggregates having nominal size $10 \mathrm{~mm}$ and $4.75 \mathrm{~mm}$ size (Figure 3-7) were used as coarse and fine aggregates, respectively as per ASTM C330 (ASTM C330, 2014) to produce LWSCC and FRLWSCC (Figure 3-7). Table 3-5 shows the gradation indicate the specification of course and fine aggregate. It also shows the gradation and physical properties of the slag coarse and fine aggregates.

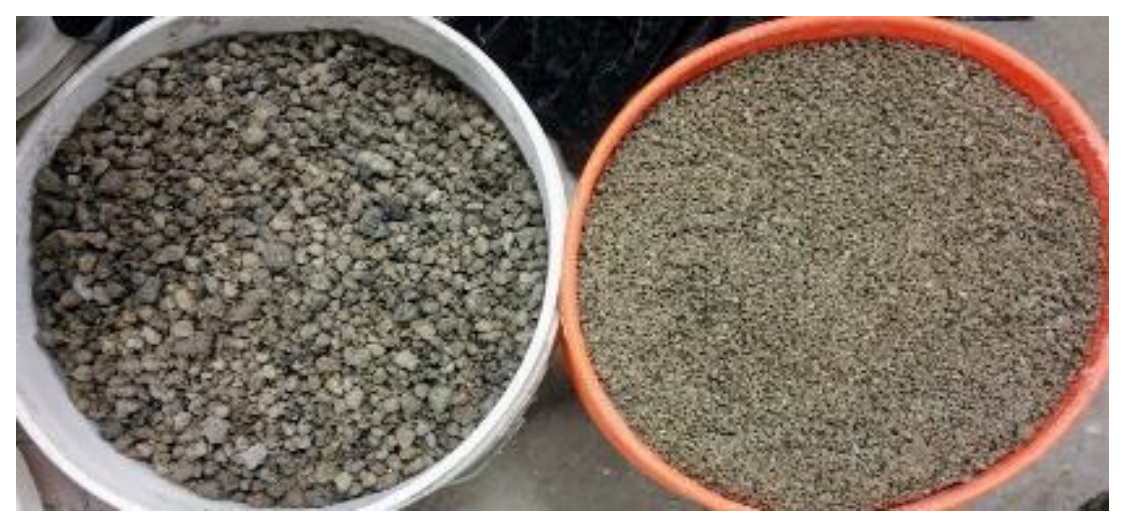

Figure 3-7: Blast furnace slag as coarse and fine aggregates for LWSCC and FRLWSCC

Table 3-5: Lightweight slag aggregate gradation and properties

\begin{tabular}{|c|c|c|c|c|}
\hline \multirow{3}{*}{$\begin{array}{l}\text { Sieve Size } \\
(\mathrm{mm}) \\
13.2\end{array}$} & \multicolumn{4}{|l|}{ Passing (\%) } \\
\hline & \multicolumn{2}{|c|}{ ASTM- C330 Specifications } & \multicolumn{2}{|c|}{ Slag aggregate } \\
\hline & Fine & Coarse & Fine & Coarse \\
\hline 9.5 & 100 & $80-100$ & 100 & 100 \\
\hline 4.75 & $85-100$ & $5-40$ & 98.96 & 90.3 \\
\hline 2.36 & -- & $0-20$ & 80.44 & 23.2 \\
\hline 1.18 & $40-80$ & $0-10$ & 44.24 & 10.2 \\
\hline 0.3 & $10-35$ & - & 5.24 & - \\
\hline 0.15 & $5-25$ & - & 1.24 & - \\
\hline 0.075 & - & $0-10$ & 0 & \\
\hline Bulk Specific Gravity (dry) & - & & 2.17 & 1.61 \\
\hline Bulk Specific gravity (SSD) & - & - & 2.2 & 1.75 \\
\hline Dry loose bulk density $(\mathrm{kg} / \mathrm{m} 3)$ & $1120(\max )$ & $880(\max )$ & 1356 & 950 \\
\hline
\end{tabular}



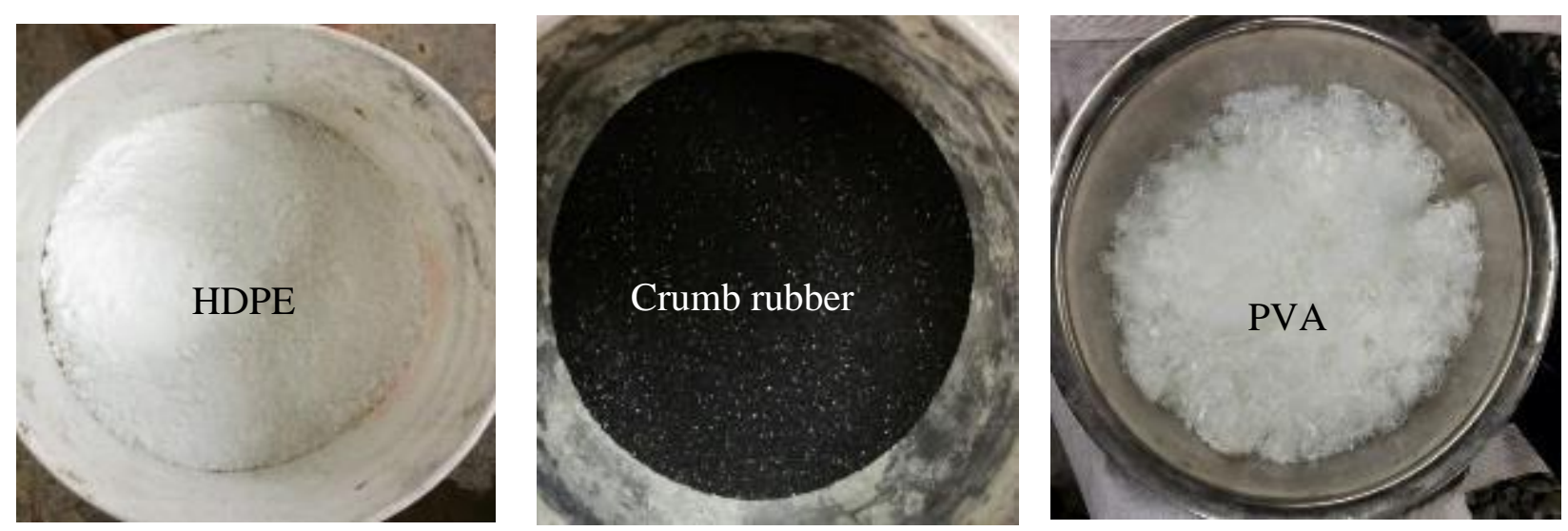

Figure 3-8: HDPE, Crumb rubber and PVA fiber used for LWSCC and FRLWSCC

During the preparation of LWSCC/FRLWSCC, 72-hour, pre-soaked course and fine slag aggregates were used. Excess water was allowed to drain out without losing aggregate. The saturated surface air dry aggregate was used for mixing and proper water adjustment (reduce 5\%) was made bestowing the water absorption of the aggregate and moisture content of the aggregate at the time of mixing. A polycarboxylate based high range water reducing admixtures (HRWRA) - Master Glenium 7500 was used into LWSCC mix to satisfy ASTM C494/ C494M requirements for Type A, water-reducing, and Type F, high range water reducing, admixtures ASTM C494 (2016).

A 350 liter capacity electrical concrete mixture machine was used making LWSCC and FRLWSCC. All required materials were weighted and placed beside the mixture machine. The slag course and fine aggregates were first placed into the machine and mixed at regular speed for 2 minutes. Then cement, fly ash and silica fume were added into the mix and mixed for 2 minutes. Mixing continued for additional 5 minutes while adding water slowly until getting the proper mix. For fiber, reinforced LWSCC, mixing continued for additional 2-3 minutes by adding required quantity of fiber into the mix slowly.

Three different type fiber were applied for this research with different physical properties such as length and size. PVA and HDPE, which was white in color had different lengths and diameters. Crumb rubber was black with a sand like texture and has been made from recycled tires by grinding and has a specific gravity is 0.9 (Karahan et al. 2012). The source and summary of the characteristics 
of the fibers used in this research have been summarized in the Table 3-6. Figure 3-8 shows PVA, HDPE fibers and crumbed rubber.

Table 3-6: Geometrical and mechanical properties of PVA fiber

\begin{tabular}{|l|l|l|l|l|l|l|}
\hline Fiber type & \multicolumn{1}{|c|}{ Source } & $\begin{array}{c}\text { Product } \\
\text { Specification }\end{array}$ & $\begin{array}{c}\text { Length } \\
(\mathrm{mm})\end{array}$ & $\begin{array}{c}\text { Specific } \\
\text { Gravity } \\
\left(\mathrm{g} / \mathrm{cm}^{3}\right)\end{array}$ & $\begin{array}{c}\text { Melting } \\
\text { Point } \\
\left(\mathrm{o}^{\mathrm{C}}\right)\end{array}$ & $\begin{array}{l}\text { Diameter } \\
(\text { Microns })\end{array}$ \\
\hline PVA & Nycon & PVA RECS15 & 8 & 1.3 & 225 & 38 \\
\hline HDPE & $\begin{array}{l}\text { Mini Fibers } \\
\text { INC }\end{array}$ & $\begin{array}{l}\text { (ShortStuff) } \\
\text { ESS5F }\end{array}$ & 0.1 & 0.96 & 135 & 5 \\
\hline
\end{tabular}

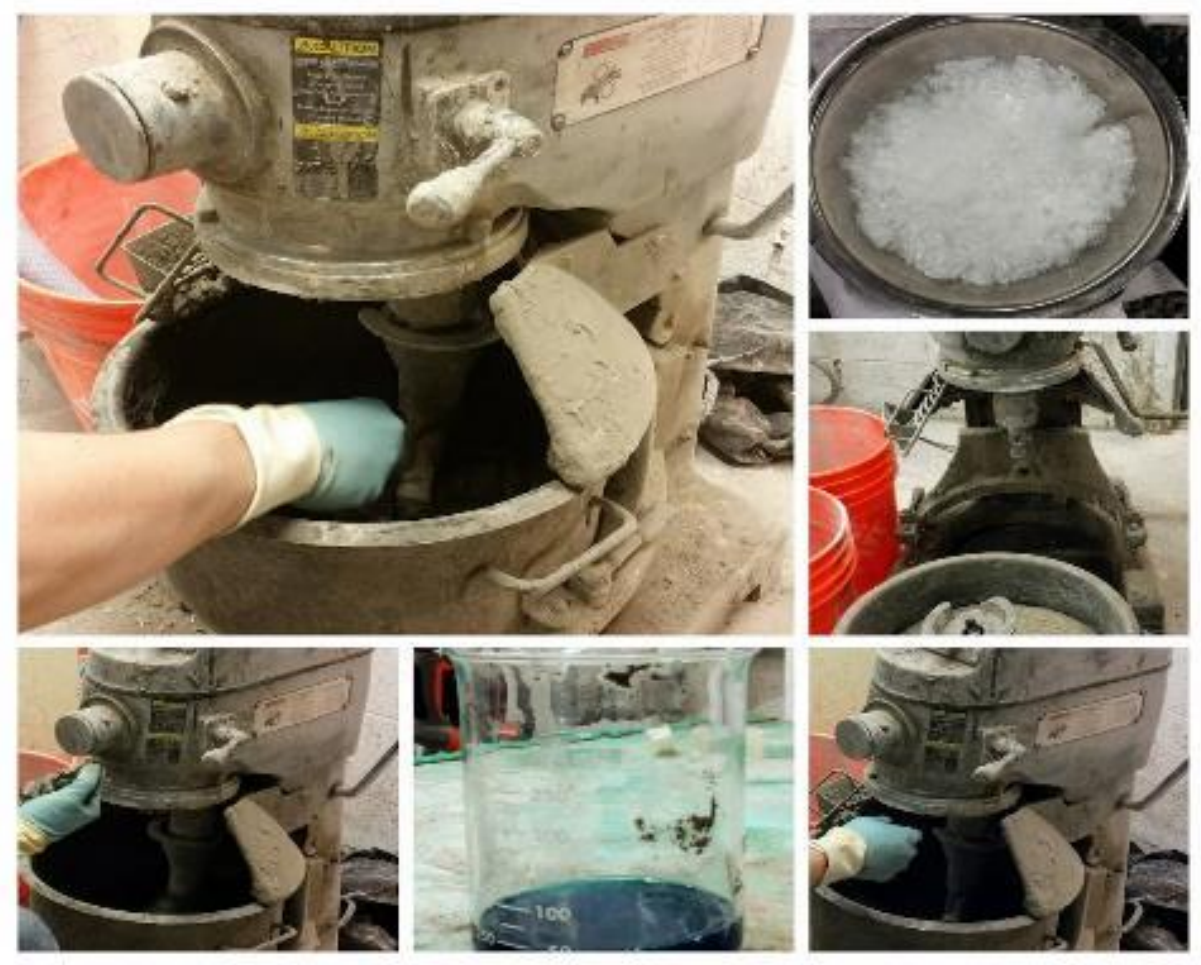

Figure 3-9: Production of ECC using a Hobart type mixture

A 20-liter capacity high shear Hobart mixture used for ECC production. All required materials (cement, silica sand, fly ash, HRWRA, water and PVA fiber were prepared and weight as per batch requirements following the mix design presented in Table 3-3. The following steps were involved in the mixing procedure: cement, fly ash and silica sand were added into a bucket and mixed at a speed of $100 \mathrm{rpm}$ for 4 minutes, then $90 \%$ of water and superplasticizer were added into the dry mixture and mixed at $150 \mathrm{rpm}$ for 5 minutes followed by addition of remaining $10 \%$ water and 
mixed at $300 \mathrm{rpm}$ for 2 minutes and finally mixed for another 5 minutes while adding PVA fiber slowly. Figure 3.9 shows the production of ECC mixture.

A commercial SCC mix available in $30 \mathrm{~kg}$ bag was used in this study. The SCC mix had $10 \mathrm{~mm}$ maximum size stone coarse aggregates, Portland cement, sand, silica fume, air entering admixtures and HRWRA. For each bag, 2.4 liters of water was used to prepare SCC. The dry mixture was put into the mixture machine, $50 \%$ water added to the dry content and then mixed for a period of 3 minutes. Next, $50 \%$ water was added slowly to the mix during additional 2 to 3 minutes of mixing until a proper mix with required consistency was achieved..

\subsubsection{Reinforcement properties}

Coupon tension tests were performed based on ASTM E8/E8M (ASTM E8/E8M, 2016) to determine the yield and ultimate strength of the $6 \mathrm{~mm}$ and $10 \mathrm{~mm}$ rebars used in the beam specimens as shown in Figure 3-10. The stress-strain responses of steel bars are shown in Figure 3-11. The properties of steel bars are summarized in Table 3-7.

Table 3-7: Rebar stress and strain response

\begin{tabular}{|l|c|c|c|c|c|c|c|}
\hline \multirow{2}{*}{$\begin{array}{l}\text { Rebar } \\
\text { diameter } \\
(\text { Actual })\end{array}$} & $\begin{array}{c}\text { Yied strength }\left(\mathrm{f}_{\mathrm{y}}\right) \\
(\mathrm{MPa})\end{array}$ & \multicolumn{3}{|c|}{$\begin{array}{c}\text { Ultimate strength }\left(\mathrm{f}_{\mathrm{u}}\right) \\
(\mathrm{MPa})\end{array}$} & \multicolumn{3}{c|}{ Yield Strain (macrostrain) } \\
\cline { 2 - 8 } & & Bar 1 & Bar2 & Average & Bar 1 & Bar2 & Average \\
\hline $6.5 \mathrm{~mm}$ & 466 & 440 & 481 & 490 & 1895 & 1892 & 1893 \\
\hline $11.27 \mathrm{~mm}$ & 466 & 466 & 466 & 650 & 2330 & 2380 & 2355 \\
\hline
\end{tabular}

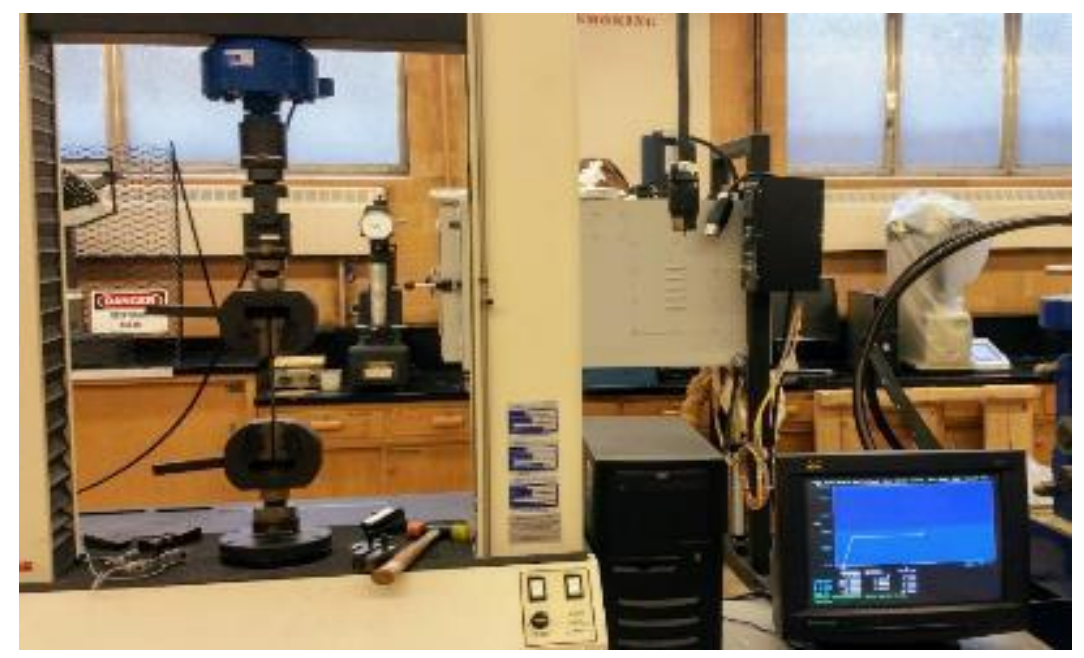

Figure 3-10: Coupon tension test of reinforcing bars 

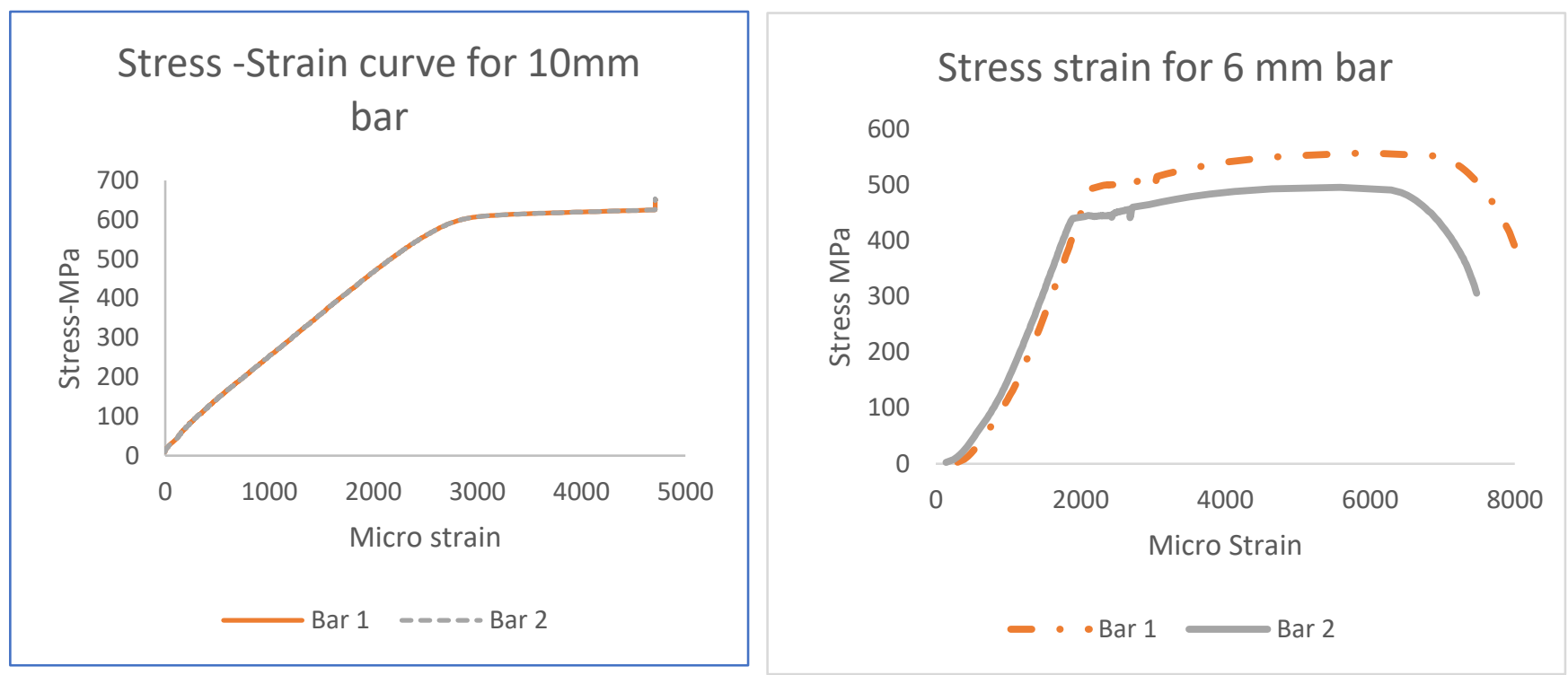

Figure 3-11: Stress-strain responses of reinforcing bars

\subsection{Beam specimen fabrication, casting and curing}

Wooden form works and rebar (stirrup and main reinforcement) were prepared for casting SCC, LWSCC, ECC, FRLWCC and SCC/LWSCC-ECC composite beams (with ECC cover layer and wrapping). Figures 3-12 (a-d) show the typical formwork showing the formwork of beams with reinforcement assembly and casting with concretes. Full-depth beams (with SCC, LWSCC, ECC and FRLWSCC) were cast immediately after concrete mixing in a single shot. For composite beams with ECC layer, bottom ECC layer was cast first and then after 24 hours, SCC or LWSCC

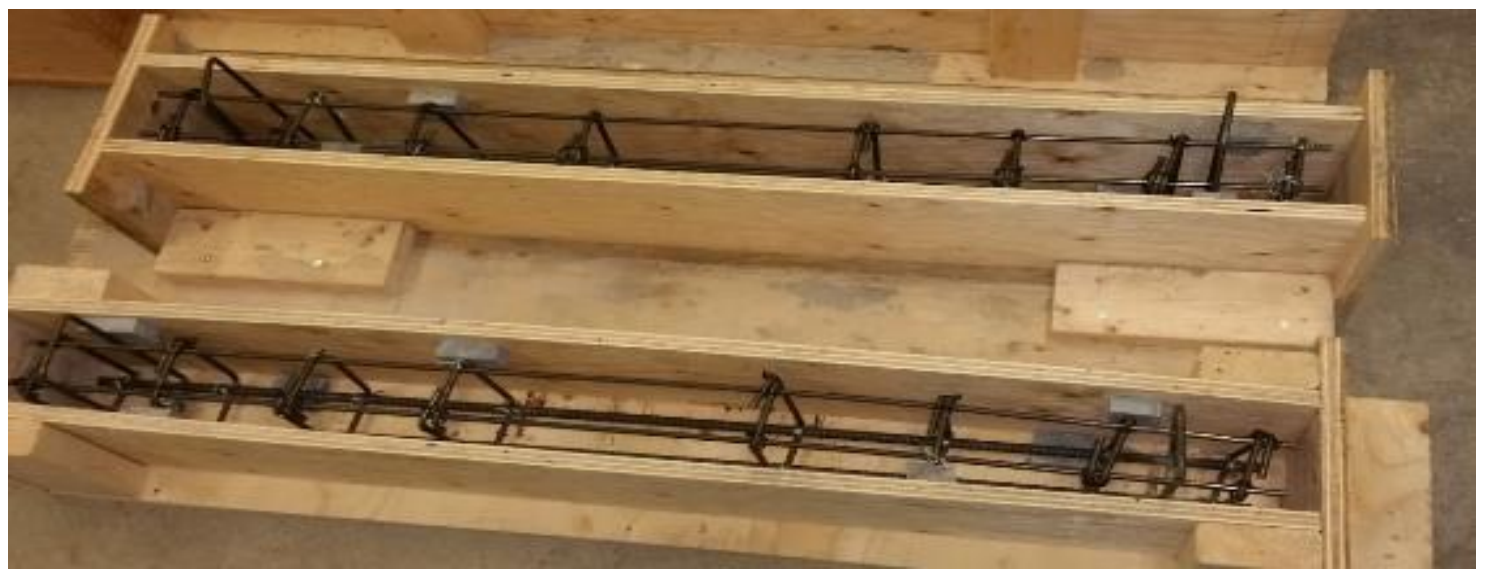

Figure 3-12 (a): Formwork showing reinforcement casing 
was cast on the ECC layer. For LWSCC-ECC composite beams with ECC wrapping, the inner LWSCC core with reinforcement was cast first and then after 24 hours ECC wrap/cover around the core was cast.

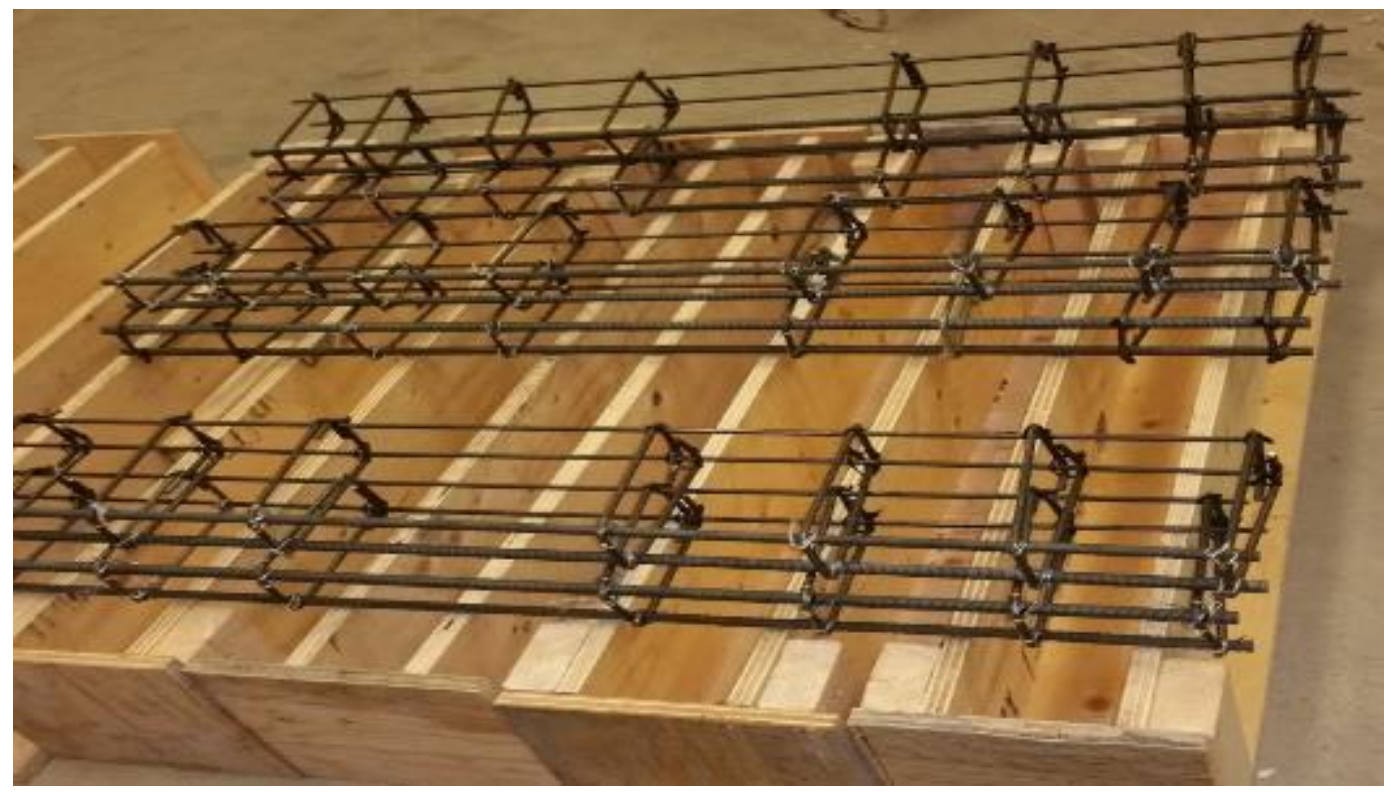

Figure 3-12 (b): Mould or formwork showing reinforcement casing and rebar assembly

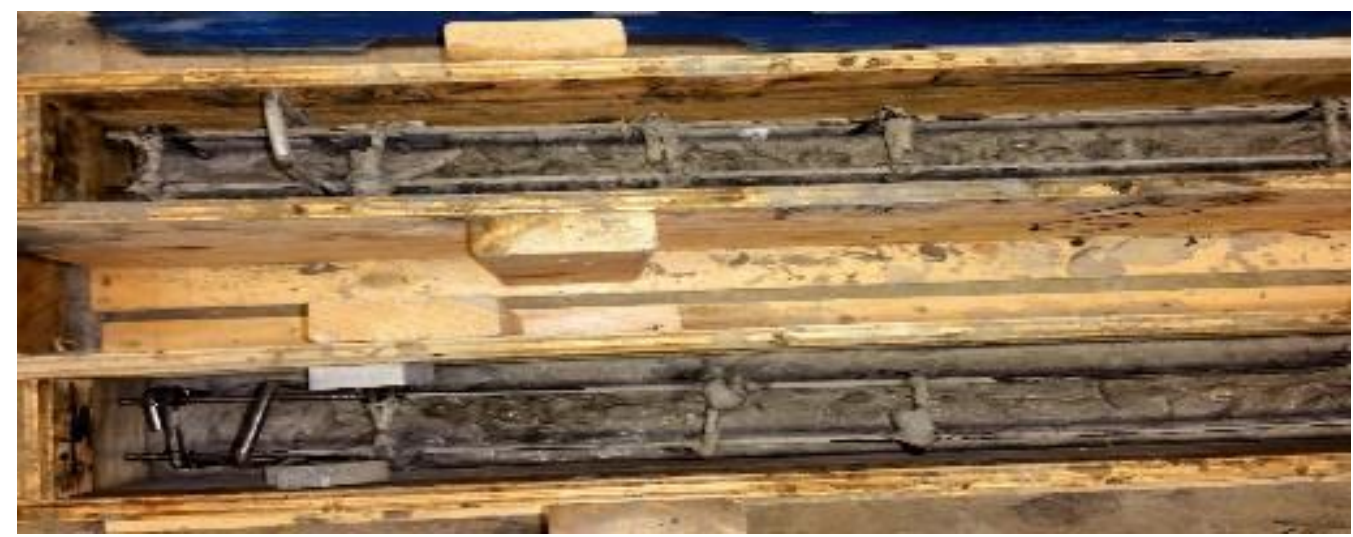

Figure 3-12 (c): Beam casting showing of ECC layer 


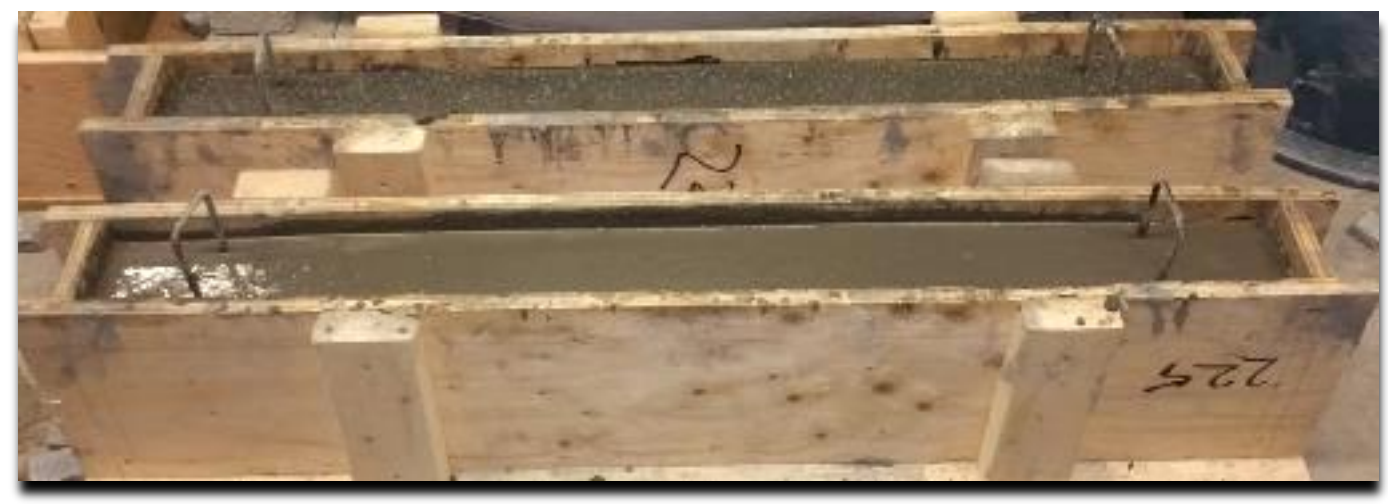

Figure 3-12 (d): Beam casting showing of SCC and LWSCC

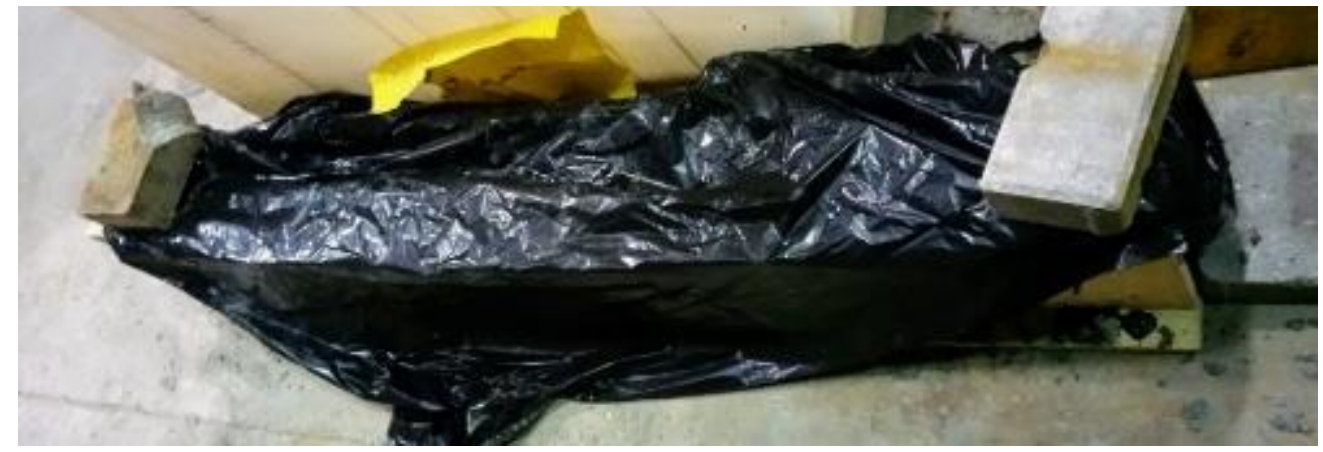

Figure 3-13(a): Curing of beams and control specimens for 24 hours in the form work

Control cylinders and small beam specimens from SCC, ECC, LWSCC and FRLWSCC were also cast during casting of beam specimens in order to determine mechanical (compressive/flexural strength, stress-strain response etc,) and durability (rapid chloride permeability 'RCP') properties. The casted beam and control specimens were kept in the formwork or mold by covering with plastic wraps for 24 hours. Then they were removed from the formwork/mold and then air cured in the laboratory. Figures 3-13(a-b) show the curing of specimens in the formwork and subsequent air curing in the laboratory 


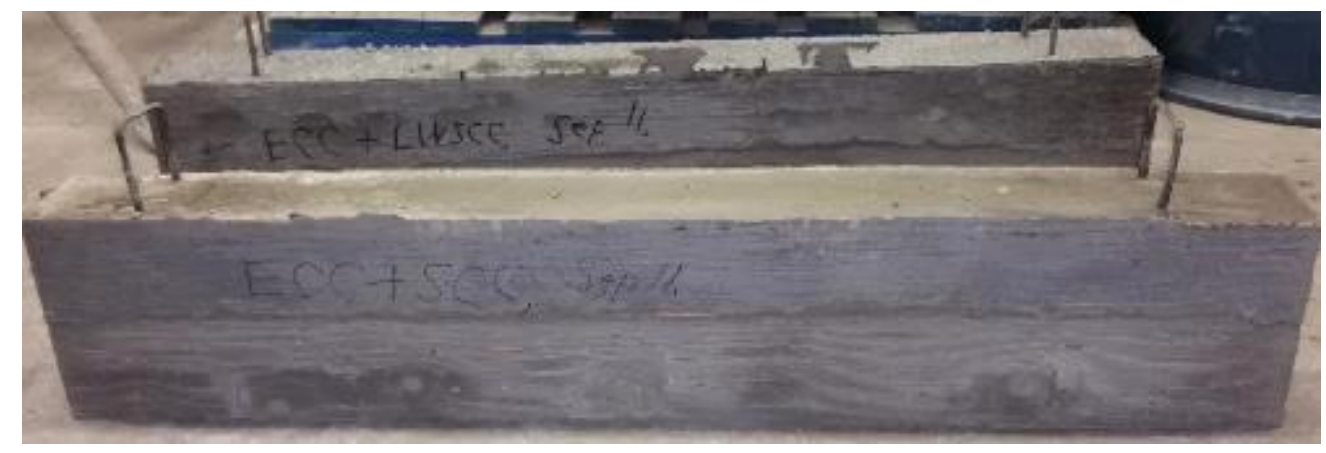

Figure 3-13(b): Formwork removal after one day of casting and subsequent air curing

\subsection{Concrete tests and testing procedures}

\subsubsection{Compressive and flexural strengths}

The compressive and flexural strengths of SCC, ECC, LWSCC and FRLWSCC were determined from 100 x $200 \mathrm{~mm}$ cylinders and $76 \mathrm{~mm}$ x $50 \mathrm{~mm}$ x $350 \mathrm{~mm}$ beams from each batch according to ASTM C39 (2008) and ASTM C78 (2013), respectively. Figure 3-14 shows the control cylinder and beam specimens made of SCC, LWSCC, FRLWSCC and ECC. Flexure strength was determined at 28 days age of control specimens using four point bending tests. The bending test was performed using a closed-loop controlled servo-hydraulic system under displacement condition at a loading rate of $0.005 \mathrm{~mm} / \mathrm{s}$ as shown in Figure 3-15. Typical flexural 

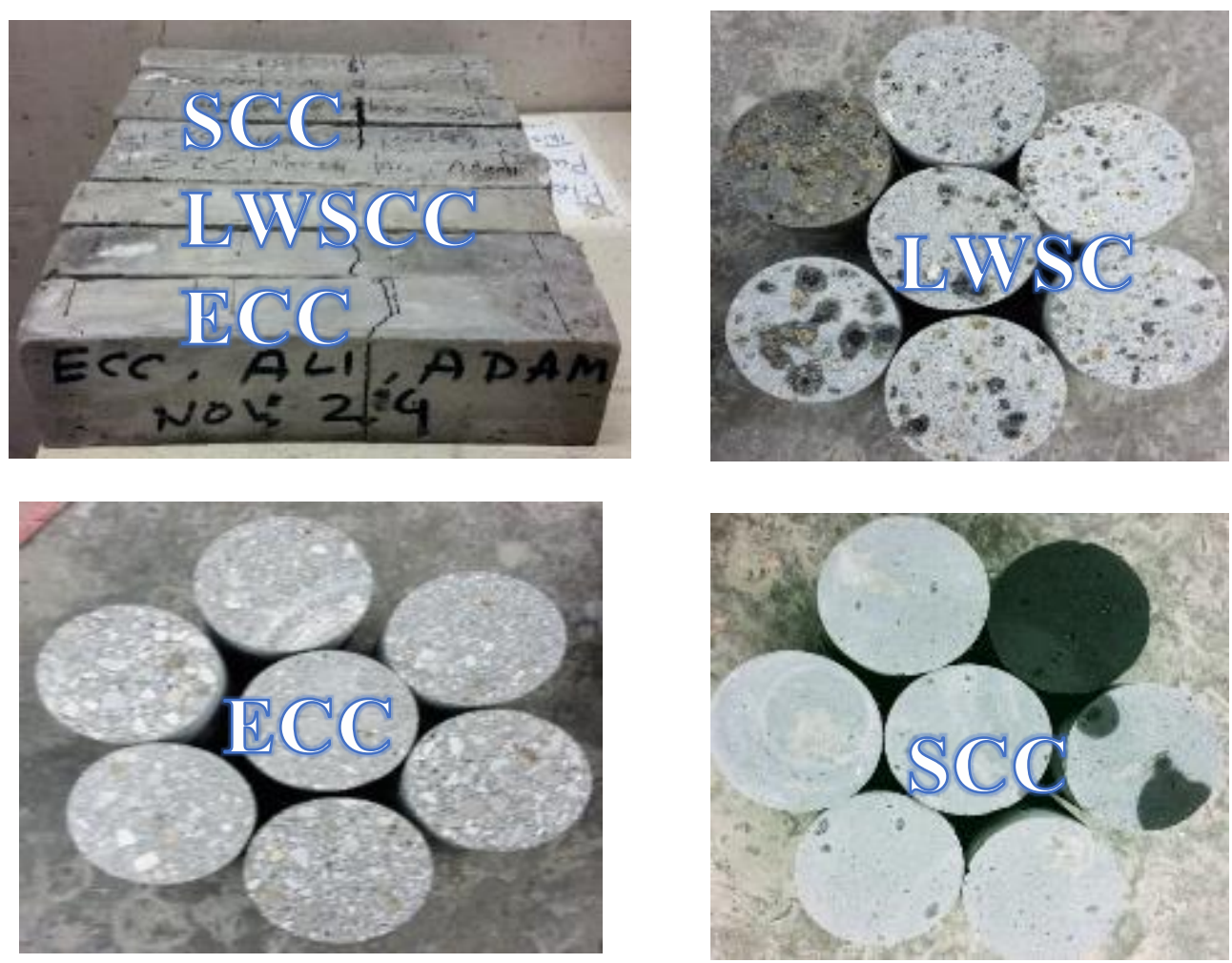

Figure 3-14: Control specimens (Beam and Cylinder)

stress vs mid-span deflection responses of SCC, ECC, FRLWSCC and LWSCC are presented in Figure 3-16. ECC showed significant post-pick strain hardening behavior due to its micro cracking characteristics compared to SCC and LWSCC. Table 3-8 shows the compressive strength and flexural strength of concrete at the age of testing (28 days) - mean value of at least three specimens are reported. Average compressive strengths were found 32.6, 30.5 and 26.0 for $1 \%$ HDPE, $1 \%$ crumb rubber and 0.25\% PVA fiber reinforced FRLWSCC respectively. As per ACI 318 (2014), to qualify as structural LWSCC, the 28-day compressive strength should be at least 17.2 MPa. 


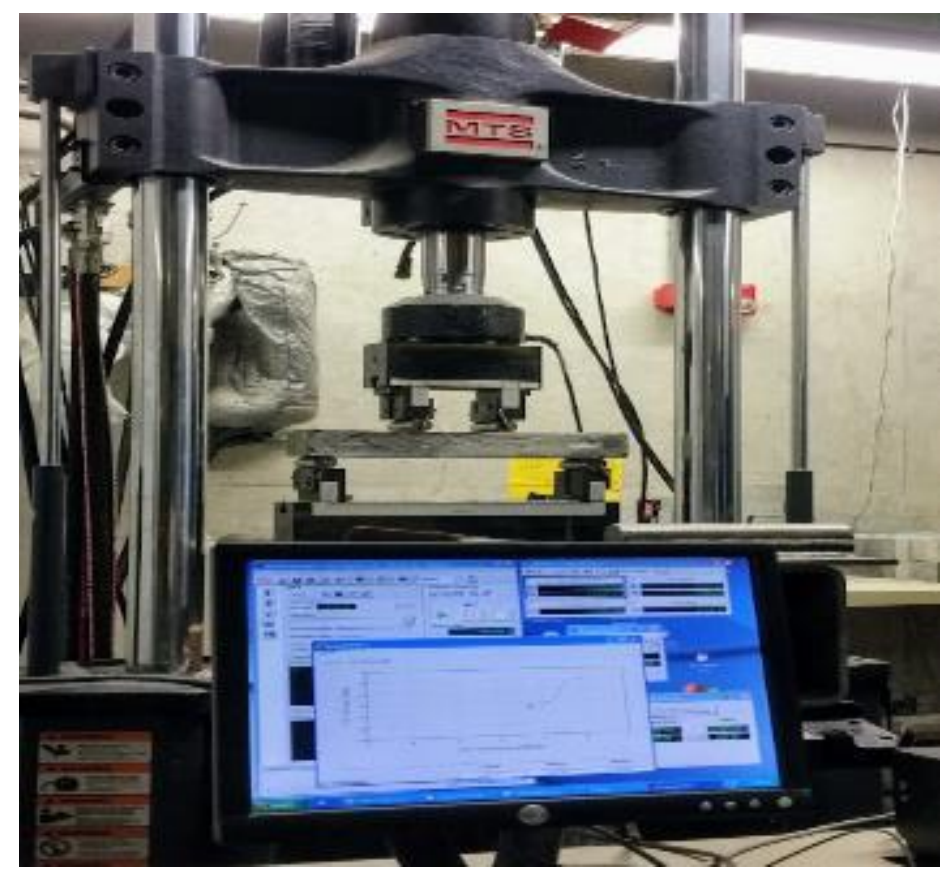

Figure 3-15: Test set-up and instrumentation for flexural strength of beam specimens

Table 3-8: Concrete strength and other properties at 28 days

\begin{tabular}{|l|l|l|l|l|l|c|}
\hline & & & & FRLWSCC & FRLWSCC & FRLWSCC \\
Material & LWSCC & SCC & ECC & PVA & CR & HDPE \\
\hline Modulus of Elasticity (MPa) & 16934 & 21204 & 18622 & - & - & - \\
\hline Compressive Strength (MPa) & 37.00 & 50.29 & 60.54 & 26 & 36.5 & 30.5 \\
\hline Flexural stress (MPa) & 3.67 & 5.44 & 12.35 & 0.94 & 1.14 & 1.08 \\
\hline
\end{tabular}
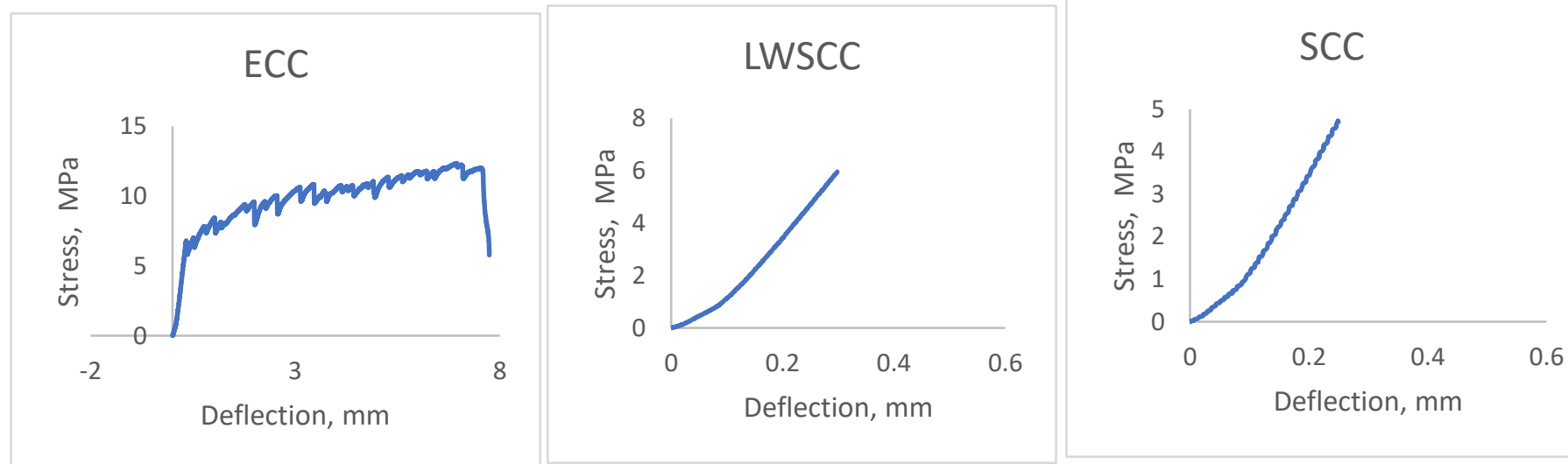

Figure 3-16: Flexural stress vs deflection responses of ECC, SCC, FRLWSCC and LWSCC 


\subsubsection{Concrete permeability test}

The permeability of the concrete is one the most important factor for ensuring durable concrete, including the corrosion protection. The permeability of concrete controls the rate of penetration of moisture, oxygen, and carbon dioxide in the concrete. Penetration of moisture is responsible for transport mechanism for chlorides and other aggressive materials. Lowering the concrete permeability increases the length of time before aggressive agents reach the steel, and thus improves corrosion protection. (Neville, 1997). According to ASTM permeability depend on following factors "water-cementitious materials ratio, type and quantity of supplementary cementitious materials in the concrete mixture, the presence of polymeric admixtures, ionic solutions of admixtures like calcium nitrite, air-void system, specimen age, aggregate type, degree of consolidation, and type of curing" (ASTM C1202-12, 2012).

Table 3-10 shows chloride ion penetrability of SCC, ECC, LWSCC and FRLWSCCs used in this study based on charge passed through cylindrical specimens as per ASTM C 1202 -12 (2012) testing procedure. According to the test, the lower the charges that passed through the specimen the higher the resistance of the sample to chloride ion penetration. ECC showed significant lower permeability compared SCC, LWSCC and FRLWSCCs. The chloride ion permeability of ECC, SCC, LWSCC and FRLWSCC can be classified as very low, low, low and low to moderate, respectively (Table 3-9) as per ASTM C 1202 -12 (2012) specifications provided in Table 3-10.

Table 3-9: Chloride Ion Penetrability of concretes (Siad, et al., 2015, Celasun, 2017)

\begin{tabular}{lll}
\hline Specimen & Charge Passed (Coulombs) & Chloride Ion Penetrability \\
\hline ECC & 466.00 & Very Low \\
SCC & 1192.00 & Low \\
LWSCC & 1070.00 & Low \\
LWSCC $+.25 \%$ PVA fiber & 1429.33 & Low \\
LWSCC $+1.0 \%$ CR fiber & 1398.33 & Low \\
LWSCC $+1.0 \%$ HDPE fiber & 2096.33 & Moderate \\
\hline
\end{tabular}

Table 3-10: Chloride Ion Penetrability Based on Charge Passed (ASTM C1202-12, 2012)

\begin{tabular}{ll}
\hline Charge passed (Coulombs) & Chloride permeability \\
\hline$>4000$ & High \\
$2000-4000$ & Moderate \\
$1000-2000$ & Low \\
$100-1000$ & Very low \\
$<100$ & Negligible \\
\hline
\end{tabular}




\subsection{Experimental setup, instrumentation and testing}

The experimental tests and setups were designed to induce accelerated corrosion of beam specimens, collect corrosion data during corrosion induction including concrete cracking/crack

propagation/spalling and conduct structural testing to failure of corroded beams in order to compare performance with non-corroded beam counterparts.

\subsubsection{Accelerated corrosion testing procedure}

The beams were first subjected to an accelerated corrosion test to reach the required high degrees of corrosion (30\% 40\% of rebar mass loss). Then both corroded and non-corroded (fresh/Virgin) beams were tested under four-point monotonic loading until failure. The objective of this test was to study the evolution of strength, mid-span deflection, failure load, mode of failure and cracking of the shear beams in high level (30\% 40\% of rebar mass loss) of corrosion. The corrosion of steel in a concrete environment is an electrochemical process. it requires an anode, a cathode, an electrolyte, and a contact between the anode and cathode. Numerous electrochemical techniques have been established to obtain qualitative information on concrete corrosion processes in a relatively short period of a few weeks. Accelerated corrosion examinations have been used effectively to determine the vulnerability of the reinforcing bars and other forms of structural steel for corrosion (Hassan et al. 2008, Wang et al. 2011, Kayali and Zhu 2005). In this method, direct current is passed into the steel reinforcement so that it becomes the anode, while an supplementary element serves as a cathode. When a constant voltage is maintained between the anode and cathode, the current level is proportional to the speed of the corrosion process.

Accelerated corrosion test used to determine rebar corrosion, check comparative corrosion resistance of SCC, ECC, LWSCC and FRSCC in reinforced beam specimens and improvement of corrosion resistance of these beams with ECC cover layer and wrapping around LWSCC core. The plastic tank, $5 \% \mathrm{NaCl}$ solution as an electrolytic and steel wire mesh were used for this test. Steel wire mesh was placed at the bottom of the tank. Two tanks (1500mm x $750 \mathrm{~mm}$ x 1200mm) were used to test 11 beams. Four beams were tested at a time in each tank. Beams were submerged half of their depth and $\mathrm{NaCl}$ solution was changed once in a week to maintain the $\mathrm{P}^{\mathrm{H}}$ level.

After completion of curing for 28-days, the concrete beams were placed in accelerated corrosion tanks. Figures 3-17 and 3-18 show the corrosion test set-up with beams submerged in the tanks. 30-volt DC power supply was used for each beam; steel wire mesh and bottom rebar of the beams were connected to the power supply in such a way that steel mesh served as a cathode and main 
longitudinal steel (bottom rebars) served as an anode. The accelerated corrosion test continued until $40 \%$ - 50\% corrosion occurred or two degree corrosion two-degree (ASTM-40/50\% corrosion).

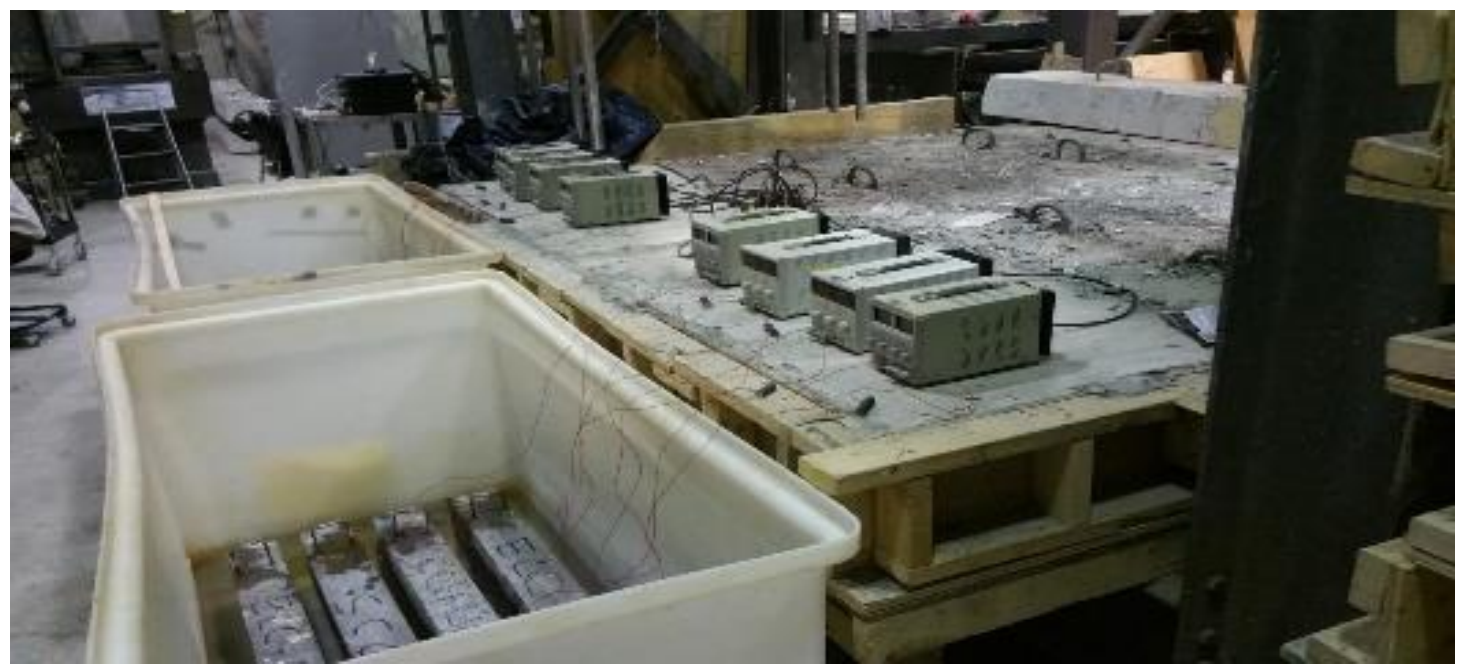

Figure 3-17(a): Accelerated corrosion test set-up - beams in tanks and DC power supply

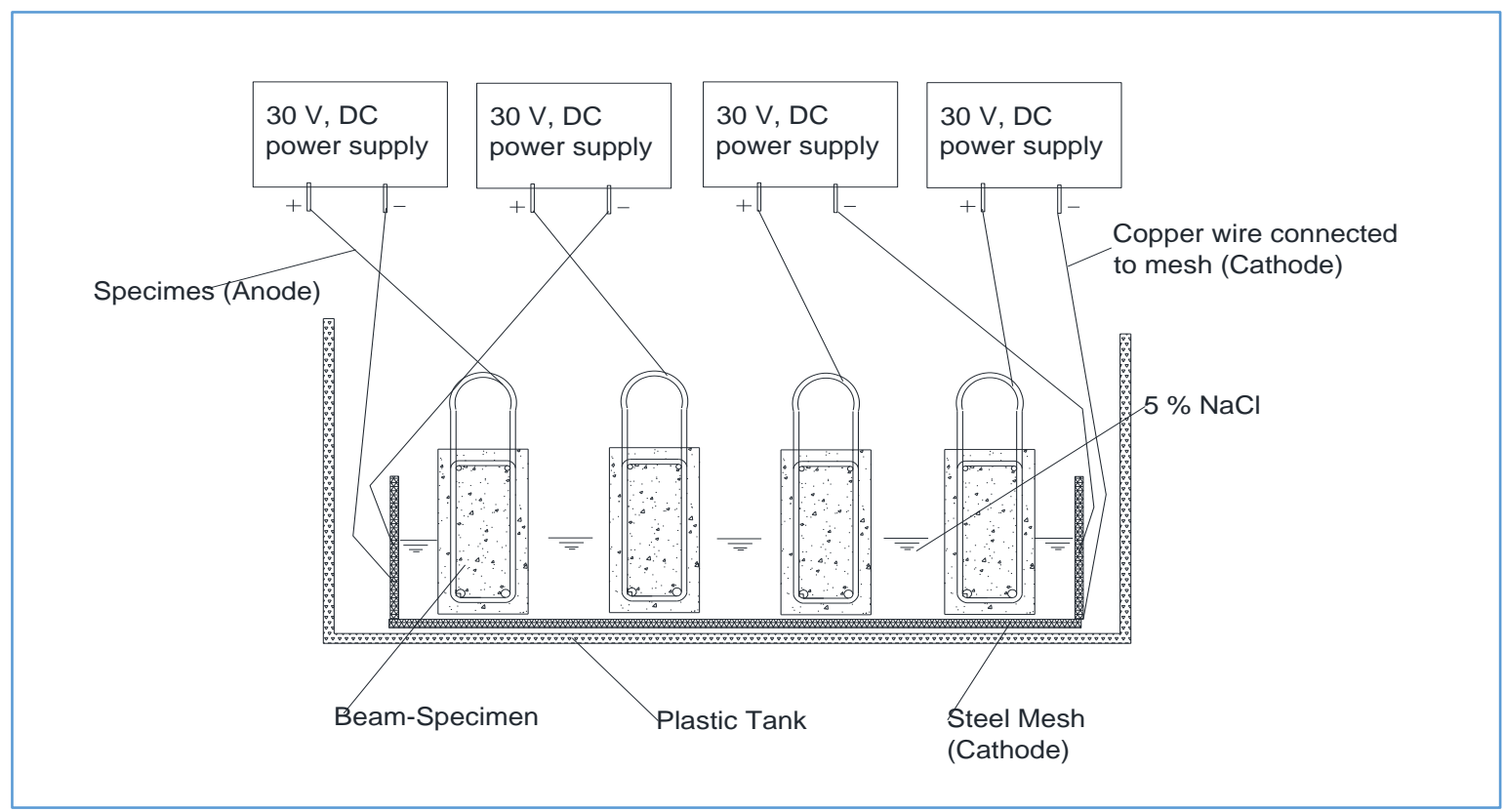

Figure 3-17(b): Accelerated corrosion setup-connection and schematic diagram test setup 


\subsubsection{Accelerated corrosion testing- current-time response, theoretical rebar mass loss and half-cell potential measurements}

After starting the test with constant $30 \mathrm{~V}$ power supply, evolution of current was measured current every 60-second interval through computerized data acquisition system. Theoretical mass losses were measured using the time ( $\mathrm{t}$ ) and current (Ampere) data using Equation 3.1 based on Faraday's second law:

Mass loss $=\frac{t \times i \times M}{z \times F}$

Where $\mathrm{t}=$ time in second, $\mathrm{I}=$ current in Ampere, $\mathrm{M}=$ atomic weight (for steel $55.847 \mathrm{~g} / \mathrm{mol}$ ) and $\mathrm{Z}=$ ion charge (2 mole of electron) and $\mathrm{F}=$ Faraday constant $(96,487)$

Cracks and other corrosion related deterioration were observed visually every two days' interval. Once in a week, when $\mathrm{NaCl}$ solutions were replaced by new one, cracking, spalling and formation of corrosion substances were observed.

Half-cell potentials were measured based on ASTM C876 (2016). Half-cell potential readings were taken every 200-mm interval along the main tensile reinforcement and two side faces of each beam using half-cell measuring device/instrument shown in Figure 3-18. The device measured the electrochemical potential difference between the reinforcement and CSE (copper-copper sulfate electrode) that was placed on the concrete surface. The instrument gave the range of letter value; each letter has a numeric negative number; more negative values indicate a higher probability of corrosion. Zero or small number indicates low or no corrosion. Half-cell measuring device showed 7 categories letter grade $\mathrm{A}$ to $\mathrm{G}$ based on voltage difference with A representing highest possible of corrosion and $\mathrm{G}$ representing the lowest as per Table 3-12 classification (Cor-Map-II, 2012).

Table 3-11: Classification of half-cell potential (Cor-Map-II, 2012)

\begin{tabular}{|l|l|l|}
\hline Designation & Reading less than & Corrosion probability \\
\hline A & $-0.42 \mathrm{~V}$ & $90 \%$ chance corrosion is occurring in this area \\
\hline B & $-0.35 \mathrm{~V}$ & $90 \%$ chance corrosion is occurring in this area \\
\hline C & $-0.28 \mathrm{~V}$ & Corrosion activity over this area is uncertain \\
\hline D & $-0.21 \mathrm{~V}$ & Corrosion activity over this area is uncertain \\
\hline E & $-0.14 \mathrm{~V}$ & $\begin{array}{l}90 \% \text { chance that no corrosion activity is present over } \\
\text { this area }\end{array}$ \\
\hline F & $-0.07 \mathrm{~V}$ & $\begin{array}{l}90 \% \text { chance that no corrosion activity is present over } \\
\text { this area }\end{array}$ \\
\hline G & $-0.00 \mathrm{~V}$ & $\begin{array}{l}90 \% \text { chance that no corrosion activity is present over } \\
\text { this area }\end{array}$ \\
\hline
\end{tabular}


Half-cell potential measurements were taken at 24 locations for each beam in each week up to two weeks. The locations of half-cell readings (on side faces and bottom surface of beam) and a snapshot of sample half-cell potential survey are shown in Figures 3-19 (a-d).

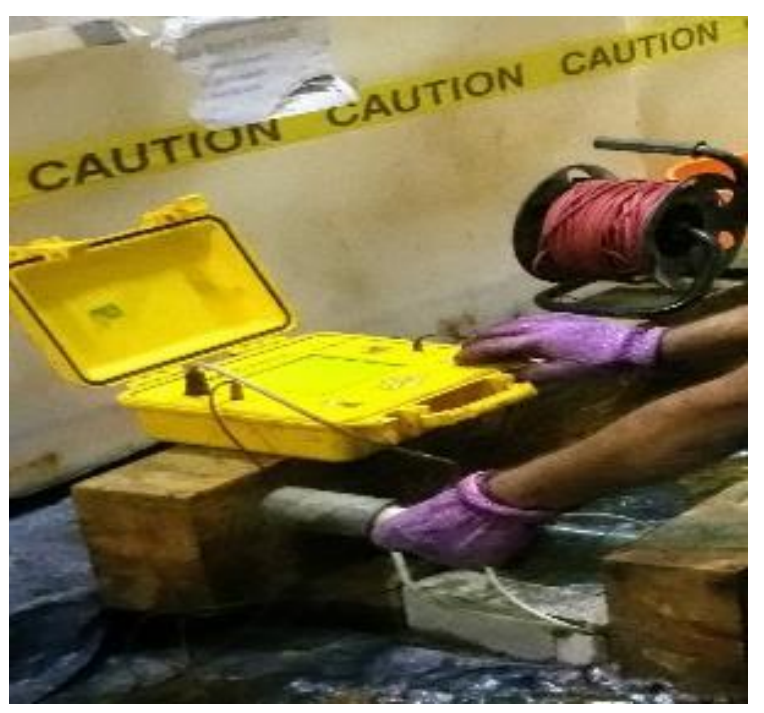

Figure 3-18: Half-cell potential measuring device

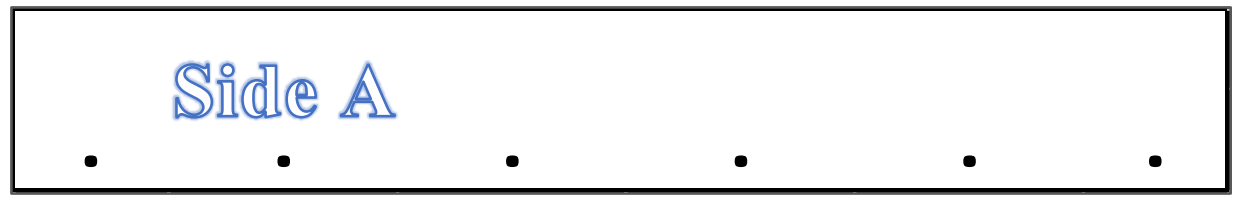

Figure 3-19(a) :Half-cell test location for side A of the beam

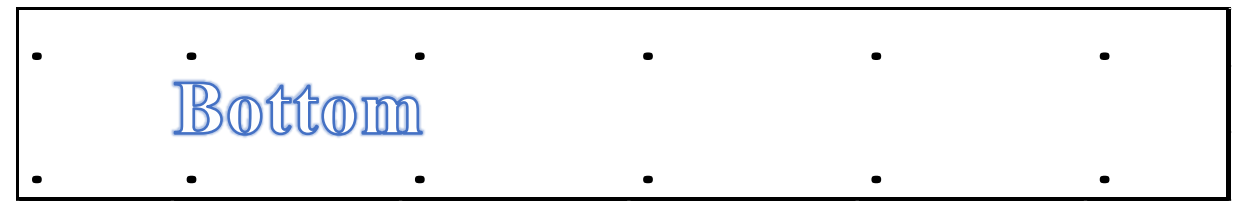

Figure 3-19(b): Half-cell test location for bottom side of the beam

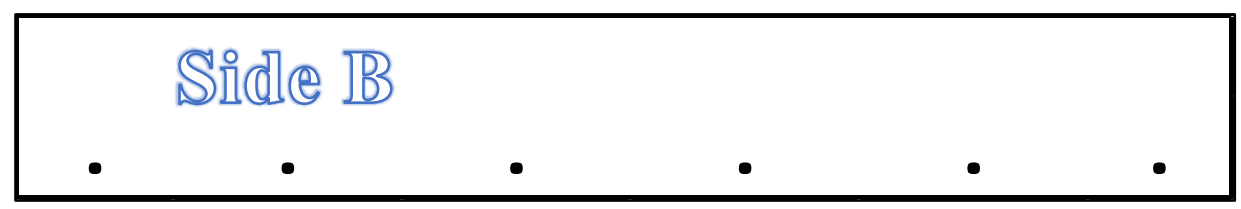

Figure3-19(c): Half-cell test location for side A of the beam 


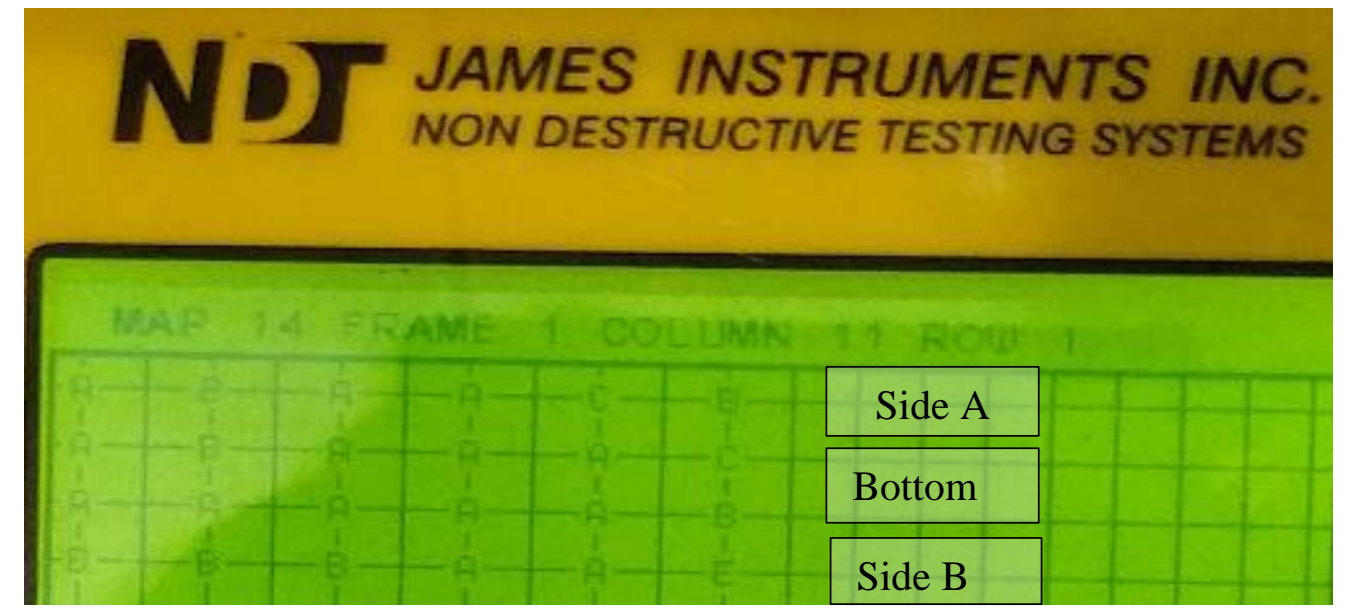

Figure 3-19(d): Sample snap-shot of half-cell potential survey

\subsubsection{Accelerated corrosion testing- Cracks pattern and spalling measure}

The cracks appeared on the surface of the concrete beams was one of the consequences of corrosion. Since the concrete is relatively weak in tension and strong in compression, the cracks start to appear on the weaker sides of the concrete around the rebar and stirrups. The crack pattern are important for following reasons: (i) crack denotes to the location, size, and degree of corrosion of the corroded rebars that caused the cracks, (ii) the expected cracks resulting from the loading test are an indicator of future structural response, (iii) shows the influence of the multi-stages of corrosion on crack shape and width, as well the total structural capacity and (iv) shows the effect of the congested rebar corrosion on its crack pattern 
Crack propagation and maximum crack width on each side of the beams were measured and documented. As long as the corrosion process continued, the pressure of the corrosion substance

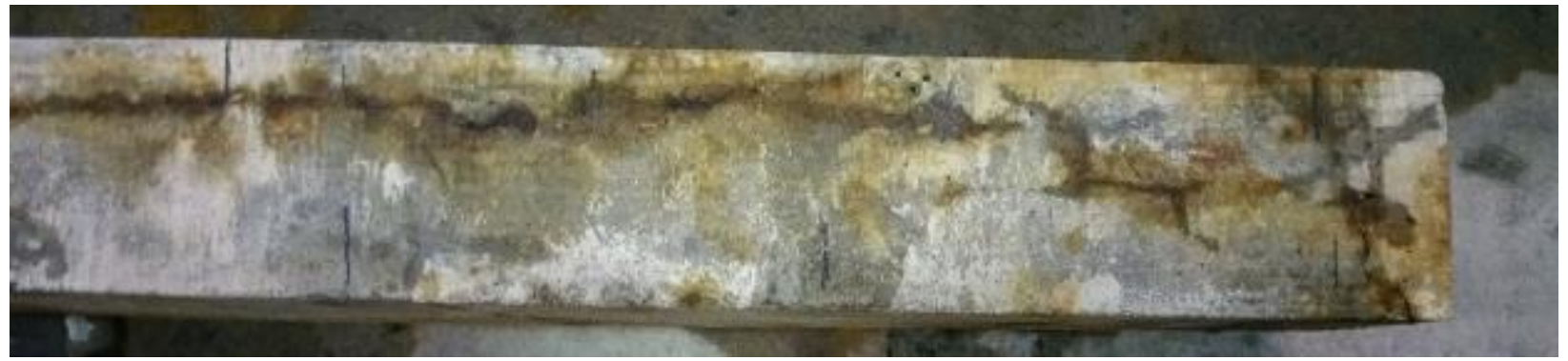

Figure 3-20(a): Typical initial cracks in SCC beam after 6 days of current flow

increased on weakened cover areas, resulting in concrete spalling in some of the beams during corrosion period- typical ones are shown in Figures 3-20 (a-b) and 3-31. The spalling occurred at the edges/corner areas with no side support and congested areas with rebars.
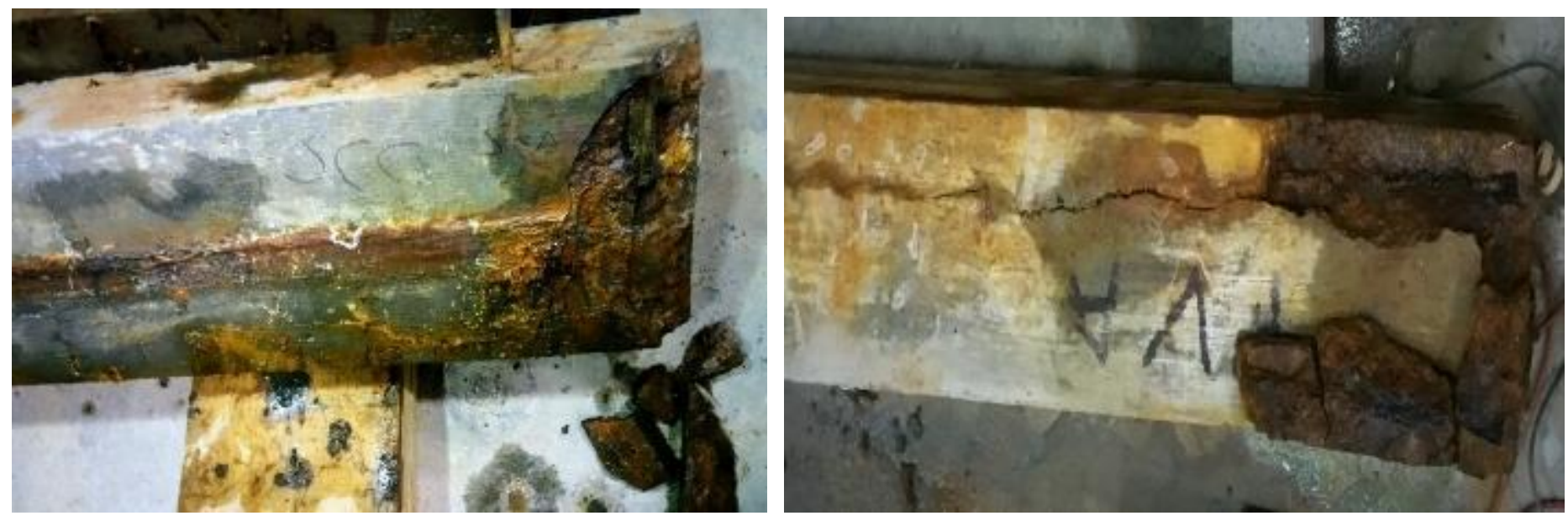

Figure 3-20(b): Typical cracking and spalling after 11 days of current flow

\subsubsection{Accelerated corrosion testing- measurement of mass loss and bar diameter after corrosion}

After the completion of the corrosion test, the beams were broken by jackhammering and corroded longitudinal bars were removed (Figure 3-21). The corroded bars were cleaned and scrubbed with 
steel wire brush to ensure that all bars were free from rust and concrete then soaked in $1: 1 \mathrm{HCl}$ and water solution.
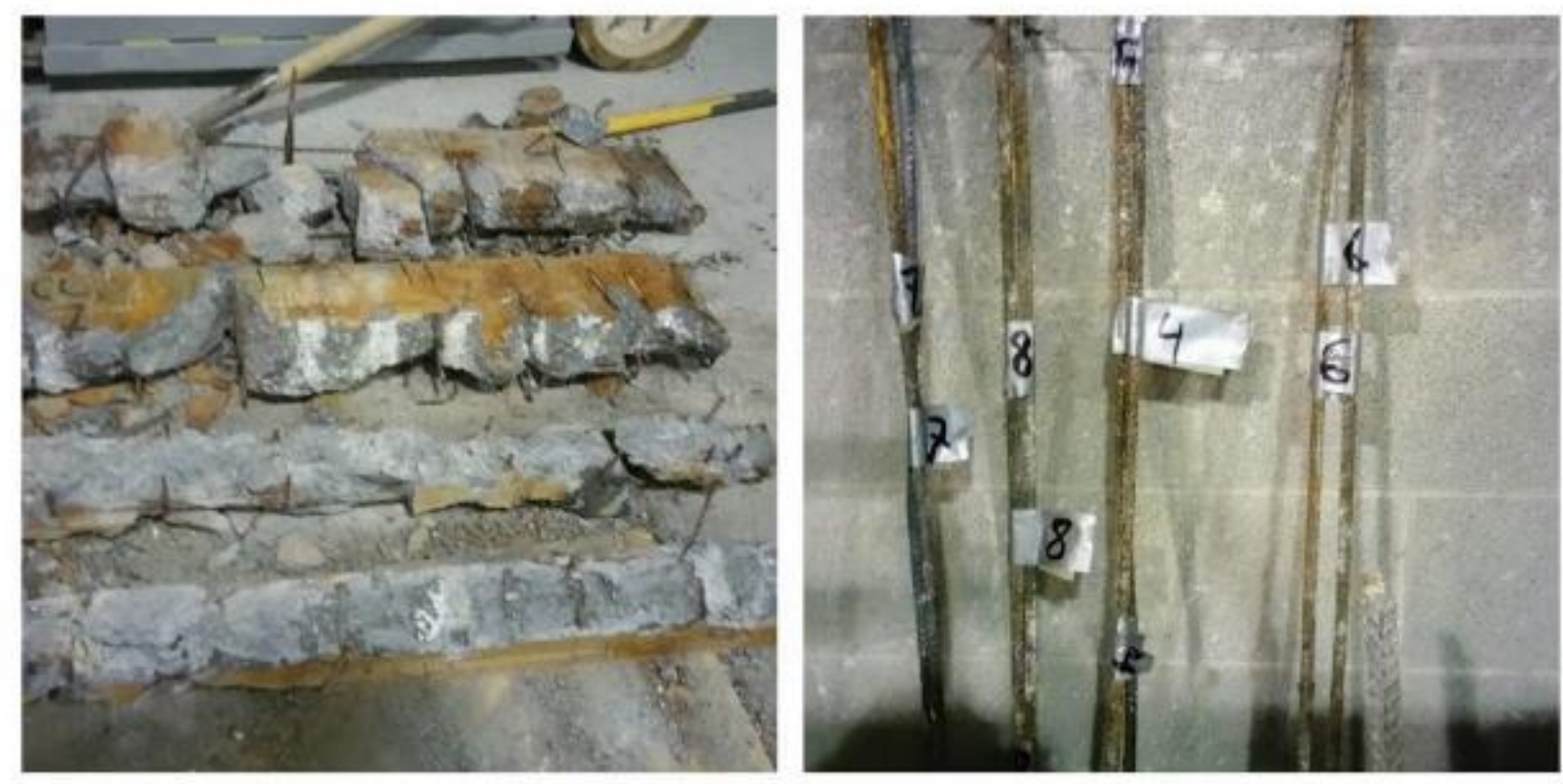

Figure 3-21: Rebar extraction from corroded beams using jack-hammer and broken beams

$\mathrm{HCl}$ and water solutions were used for cleaning corroded bar according to ASTM G1-03 (2011). The cleaned bars were weighed and the actual mass loss percentage were calculated based on Equation 3.2:

Actual mass loss $(\%)=\frac{\text { initial mass }- \text { final mass }}{\text { initial mass }} \times 100$

To examine the reduction of bar diameter and mass loss along the length of the beam, each bottom longitudinal bar was cut into 3 segments for washing in acid solutions. The clean bars were air dried, then the mass loss and bar diameters were measured. Figure 3-22 shows the corroded bar, bar segment and $\mathrm{HCl}$ acid used for cleaning. 

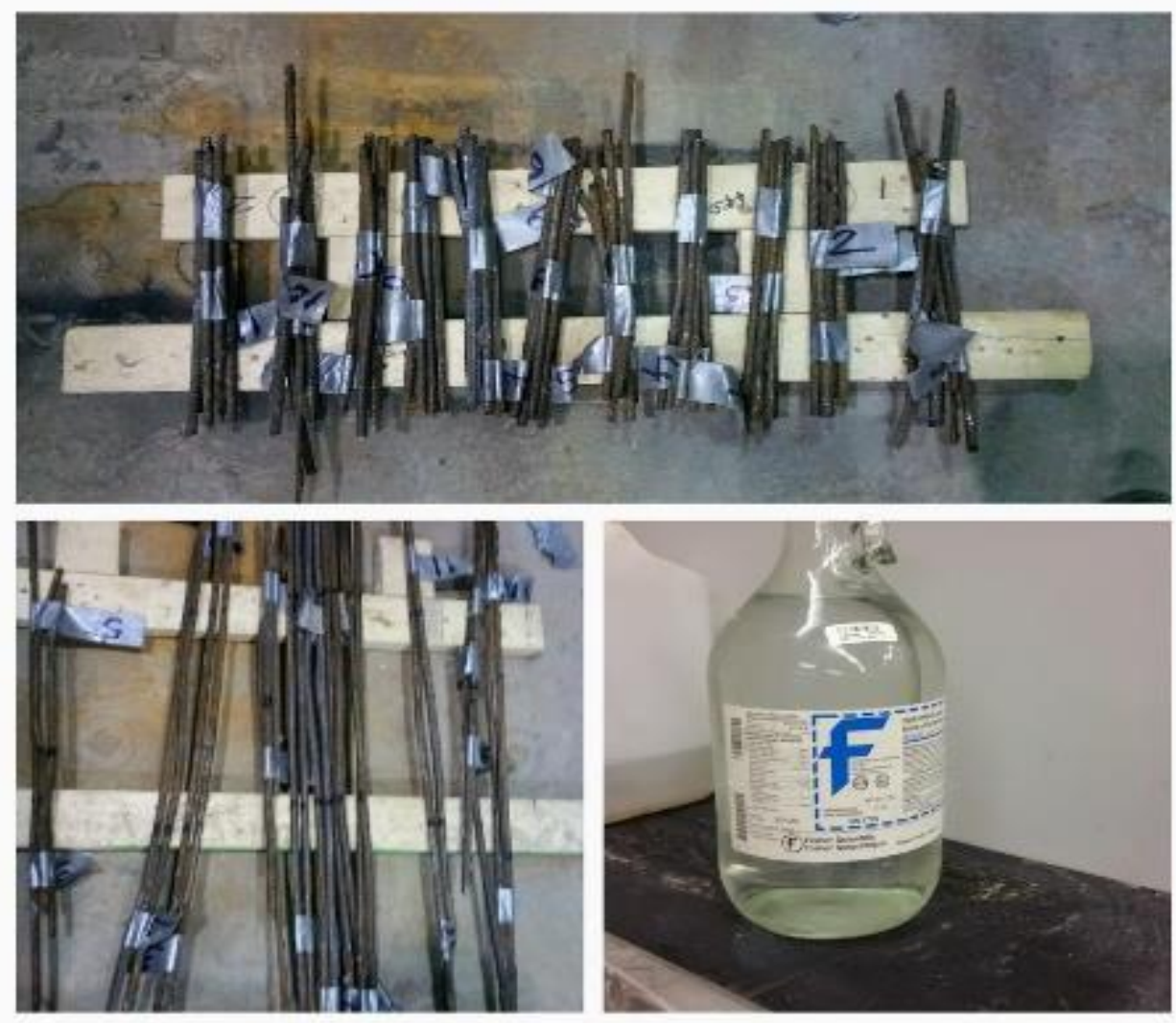

Figure 3-22: Extracted corroded bars, bar segment and $\mathrm{HCl}$ acid in bottles for cleaning 


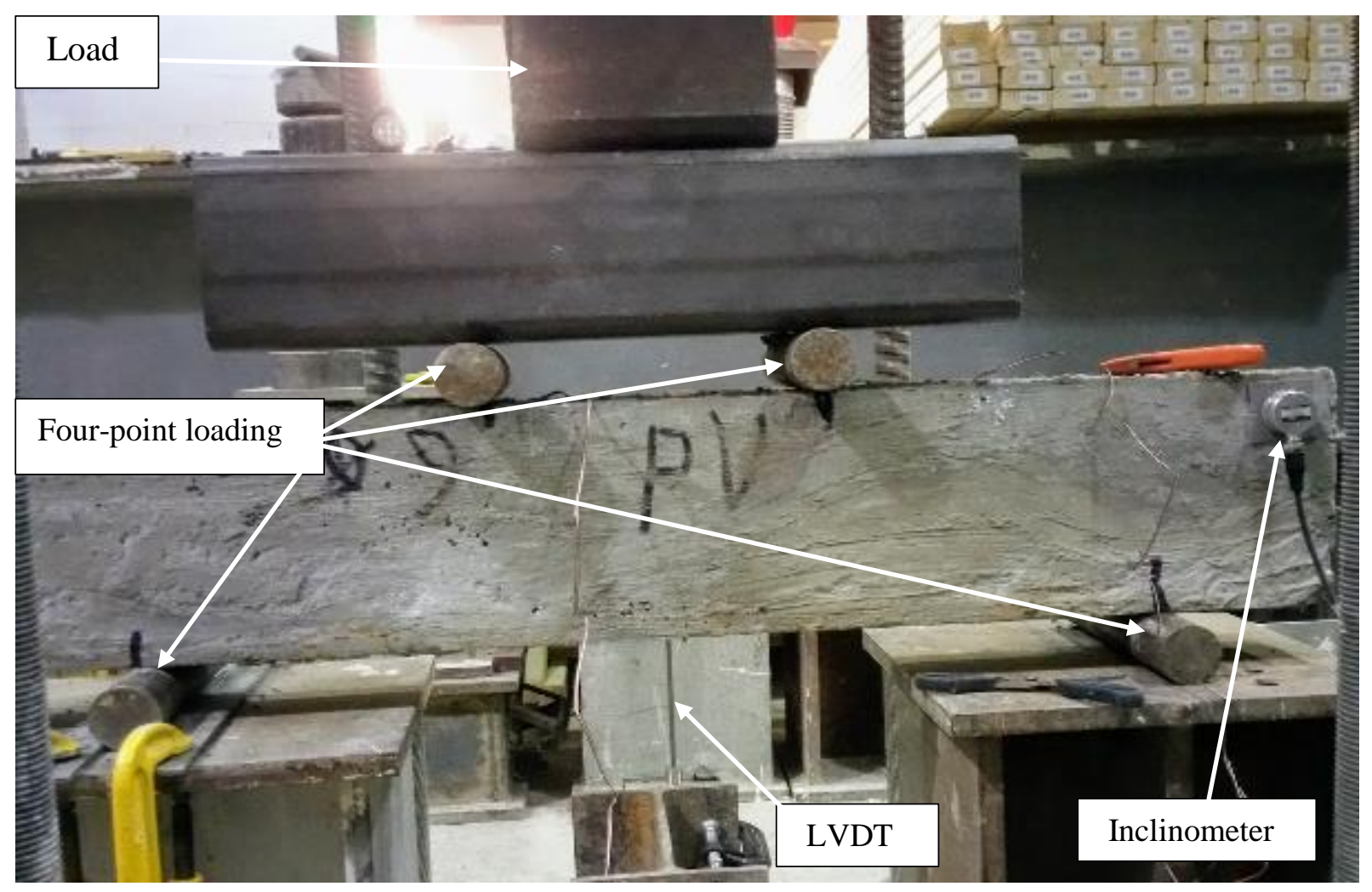

Figure 3-23: Experimental set-up and instrumentation showing fresh un-corroded beam

All beam specimens (corroded or un-corroded) were tested under simply supported condition by applying four-point loading condition based on ASTM D7250 (2016). Experimental test set-up with instrumentation is shown in Figure 3-23, 3-24 and 3-25. LVDT (Linear variable displacement transducer) was fixed at mid span to measure the deflection and one inclinometer was also fixed on the outer at the support to measure the beam rotation (Figures 3-23 and 3-24). Also, three noncorroded FRLWSCC beams were installed with strain gauges at locations shown in Figure 3-25 to record strains in flexural and shear reinforcements during loading history. 


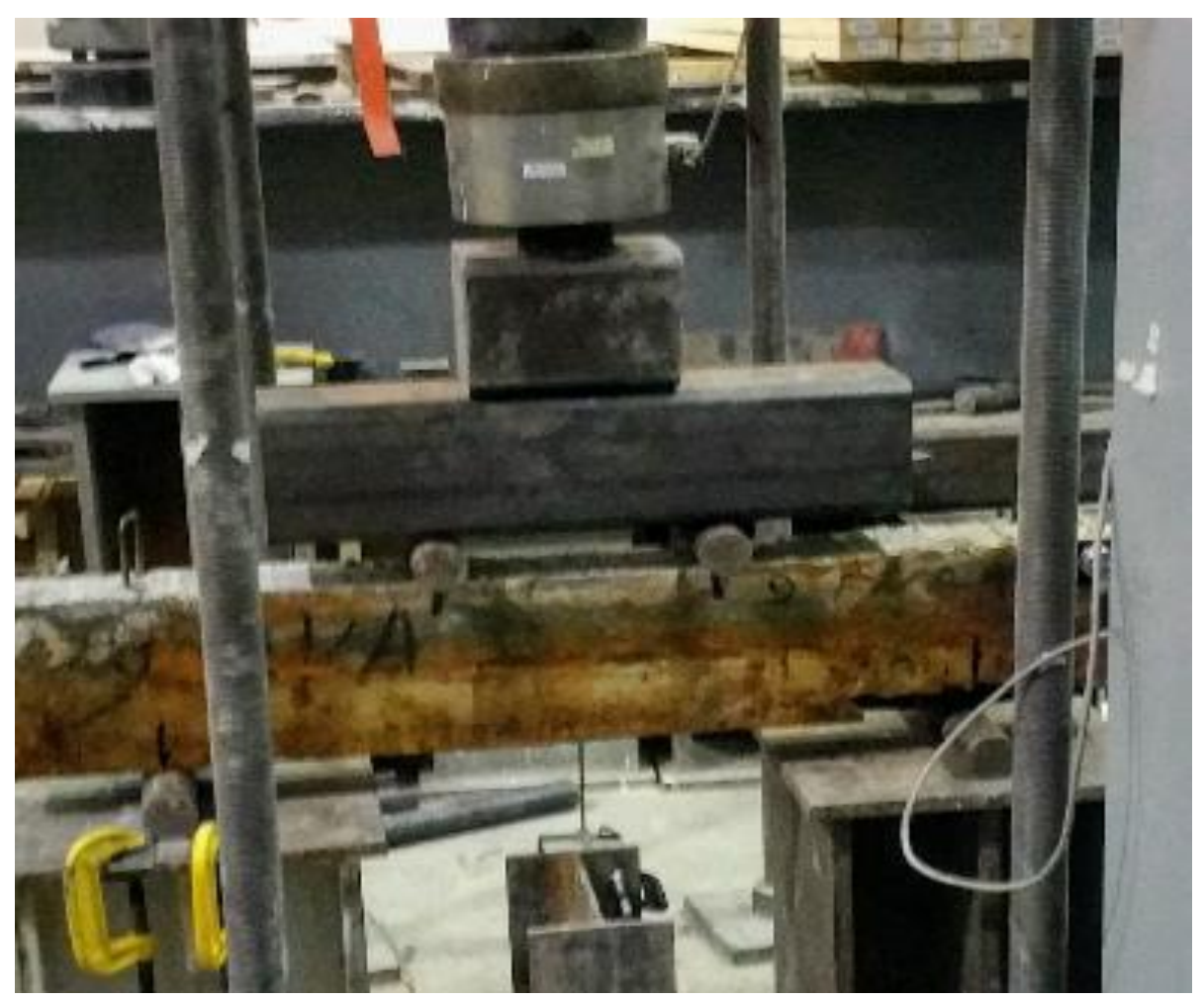

Figure 3-24: Experimental set-up and instrumentation showing a corroded beam

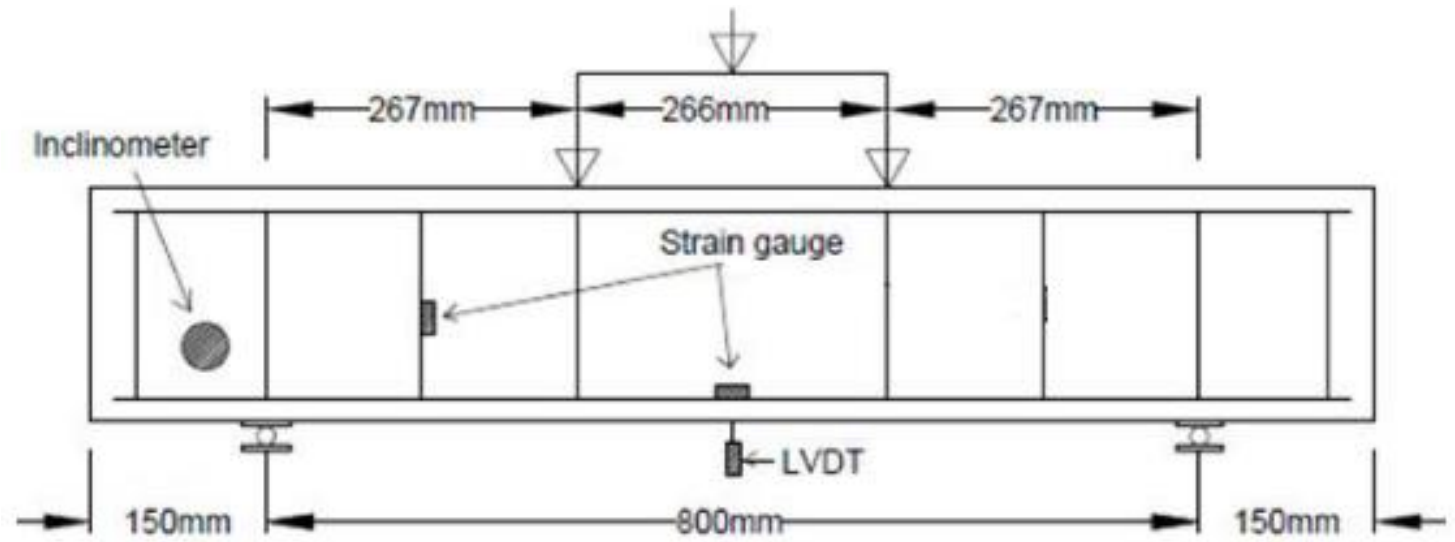

Figure 3-25: Experimental set-up for beams showing strain gauge, LVDT and Inclinometer locations 
A hydraulic jack was used to apply the 4-point loading to the beams until failure. The load was applied in increments of $5 \mathrm{kN}$ and kept constant for some minutes at each increment to observe the crack pattern. All strain gauges, load cell, LVDTs and Inclinometer were connected to a computer aided data acquisition systems to record load, deflection, rotation and strains throughout the loading history until failure. Crack development and propagation (flexural and shear cracks) formation of new cracks or propagation of existing cracks in corroded beams, cracking load (in uncorded beams) were recorded at a different stage during the test. From the test data, loaddeformation, and load-strain responses were developed. The test also provided data on the overall behavior of the beam including load transfer mechanism and failure modes.

\subsection{Summary}

The experimental research program is described by demonstrating beam specimen preparation (fabrication and casting), material properties, specimen instrumentation and test procedures. A total of 22 shear beams (11 un-corroded and 11 corroded under accelerated corrosion scheme) were tested to failure. Tests were designed to study the influence of concrete types such as SCC, ECC, LWSCC and FRLWSCC), ECC cover or wrapping in composite LWSCC-ECC beam, and thickness of ECC cover on corrosion resistance and structural performance (in terms of strength/deflection capacity and failure modes including crack propagation). The test results will be presented and described in Chapter Four. 


\section{CHAPTER 4 : EXPERIMENTAL RESULTS AND DISCUSSIONS}

\subsection{Introduction}

This Chapter presents the results of the experimental investigation on accelerated corrosion tests, corrosion resistance performance of full depth of SCC, LWSCC and ECC beams, composite beams with ECC layer or wrapping and fiber reinforced LWSCC (FRLWSCC) beams. The performance is described based on structural performance and corrosion points of view using current flow, halfcell potential test, bar diameter loss, load-deflection responses, strength loss, concrete cracking and spalling and failure modes. The main observation in the experimental test series was the effect of the level of corrosion, ECC layer or wrapping covering reinforcement or beam core, types of concrete on corrosion resistance, strength/deflection capacities and failure modes.

\subsection{Performance of beams under corrosion attack}

The performance of reinforced full depth SCC/LWSCC/ECC beams, composite beams with ECC layer or wrapping and fiber reinforced FRLWSCC beams in Group A, Group B and Group C, respectively in the following sections.

\subsubsection{General cracking observation}

Crack width and crack pattern were observed at a certain interval when half-cell potential measured and $\mathrm{NaCl}$ solutions were changed in every week during the test period.

\subsubsection{Cracking observation of full-depth SCC/LWSCC/ECC beams in group A}

Figure 4-1 showed the cracking and crack pattern of the beams after the corrosion test and Table 4-1 summarizes the results and observations. Full depth ECC/A3-C beam developed fewer cracks and less spalling. Beam ECC/A3-C also exhibited good corrosion resistance performance amongst all full depth SCC/A1-C and LWSCC/A2-C beams. In addition beam ECC/A3-C sustained 18-day corrosion test where other beams in this group SCC/A1-C and LWSCC/A2-C sustained 11 days in corrosion test. Beam ECC/A3-C had developed less longitudinal cracks $(0.1 \sim 0.25 \mathrm{~mm})$ while full depth SCC/A1-C beam had shown large amount of spalling and longitudinal crack development $(0.25 \sim 1.0 \mathrm{~mm})$ and full depth LWSCC/A2-C had longitudinal and transverse crack $(0.25 \sim 1.0 \mathrm{~mm})$ along the bottom bar and stirrups at both side. These outcomes showed the higher resilience and superior performance of ECC in rebar corrosion resistance for its dense and enhanced microstructure as well as multi-micro cracking behavior with fiber bridging characteristics. Full depth SCC beam had shown brittle behavior compared to its full depth ECC and LWSCC counterparts. The comparatively less brittle behavior of LWCC beams compared to 
SCC despite similar size of course aggregate might be associated with comparatively porous and weak lightweight slag aggregate instead of stone aggregates.
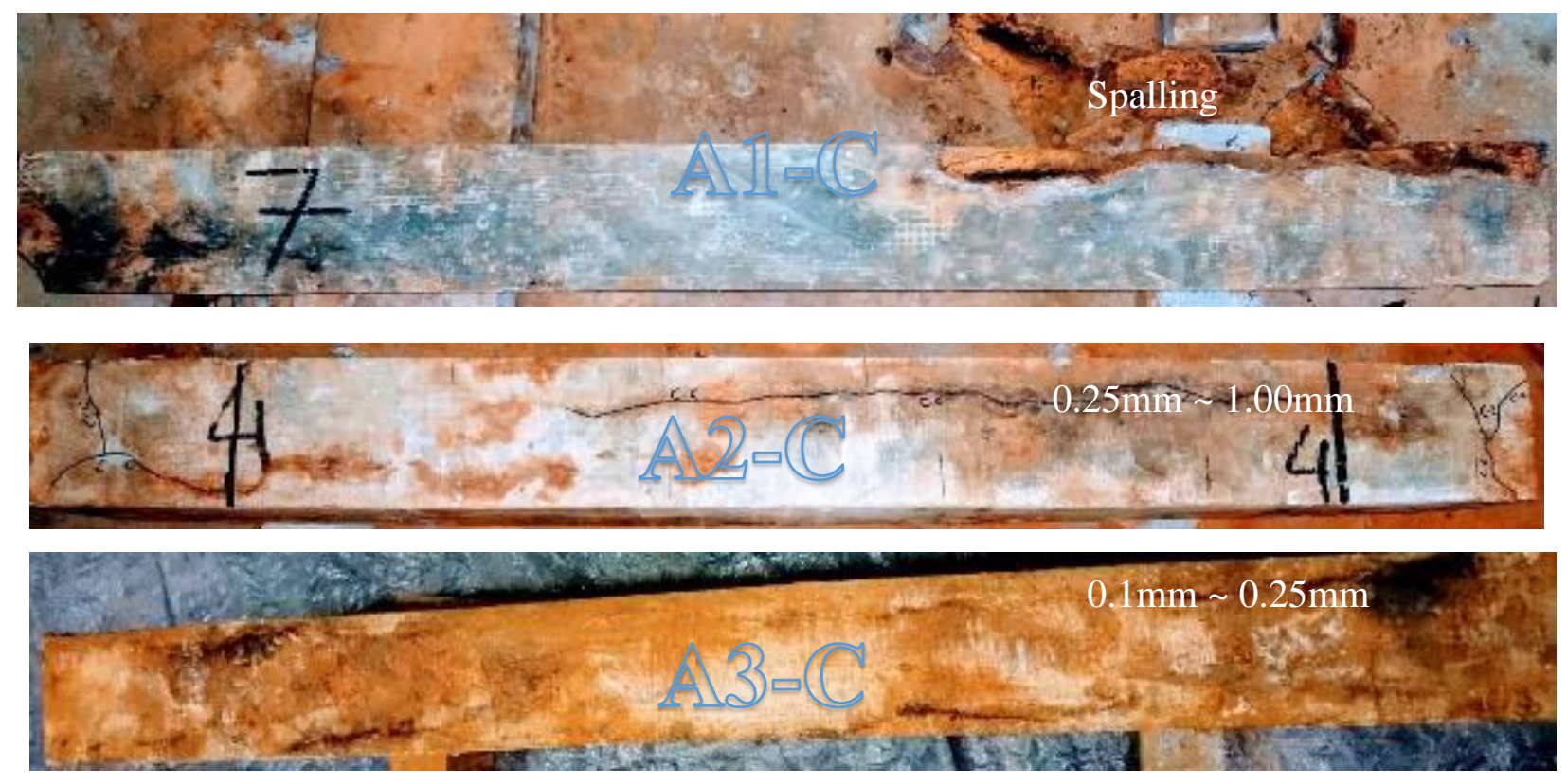

Figure 4-1:The cracks pattern of beams after corrosion test of group- A

\subsubsection{Cracking observation of SCC-ECC or LWSCC-ECC composite beams in group B}

Group B was consisted of 5 different type of composite beams. Beam SCC-ECC/B1 had 100mm ECC layer at the bottom and $125 \mathrm{~mm}$ SCC layer at the top while and LWSCC-ECC/B2 had LWSCC layer at top respectively. Beam SCC-ECC/B4-C and LWSCC/ECC/B5-C had 50mm ECC layer at the bottom and 150mm SCC and LWSCC layer at top, respectively. And, LWSCCECC/B3-C had 14mm ECC wrapping around the LWSCC core. Figure 4-2 shows the cracks and spalling of composite beams (B1-C, B2-C, B3-C, B4-C, and B5-C) and Table 4-1 summarizes the results. All five beams showed formation of no crack at the bottom side of the beams, however beam B1-C had one spalling spot at one upper corner, and B2-C had two spalling spots at two upper corners. Beam B3-C had shown no spalling or cracks. Beam B4-C had developed small cracks $(0.2 \sim 0.5 \mathrm{~mm})$ in upper SCC portion and spalling found at one side. Beam B5-C had exhibited small crack $(0.25 \sim 0.5 \mathrm{~mm})$ along the exterior stirrups and spalling found in the upper LWCC part. 
Beams B1-C, B2-C, B3-C sustained in corrosion test for 18 days; Beams B4-C and B5-C sustained in corrosion test for 11days. Based on crack pattern and spalling, corrosion test durability and visual appearance of all composite beams, Beam B3-C (LWSCC+14mm ECC wrapping) had shown better cracking and /corrosion resistance performance followed by beam B1-C (100mm ECC layer $+125 \mathrm{~mm}$ SCC layer) among the rest of the beams in the group B. This indicated that ECC wrapping around the beam core can be more effective than use as layer covering reinforcement in improving corrosion resistance.
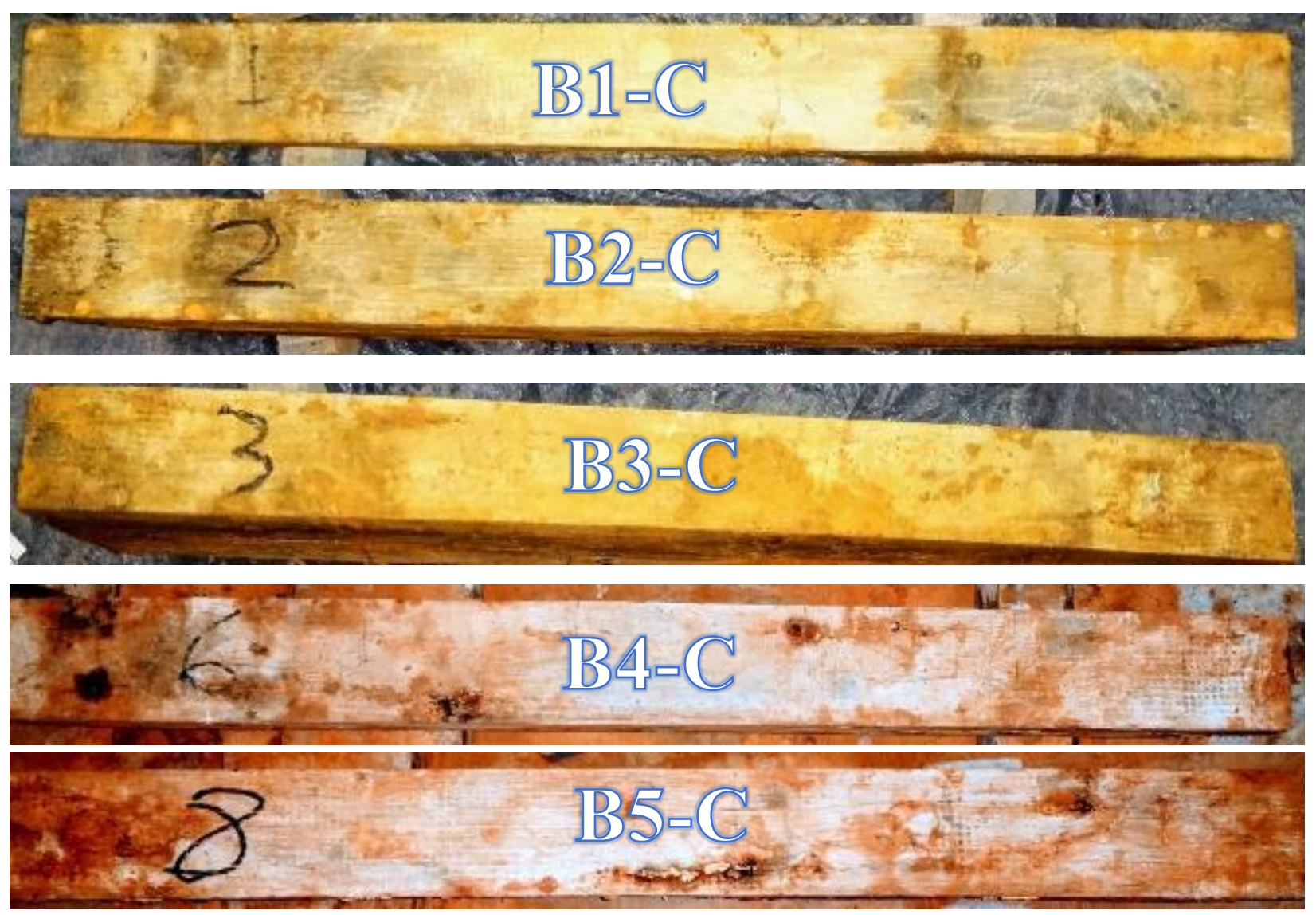

Figure 4-2: The cracks pattern of composite beams after corrosion test of group- B

\subsubsection{Cracking observations of FRLWSCC beams in group C}

Figure 4-3 shows the cracks, crack pattern and spalling of tested FRLWSCC LWSCC beams (C1C, C2-C, C3-C) with Table 4-1 summarizes the results. Beam C1-C with PVA fiber exhibited cracks $(1.00 \mathrm{~mm} \sim 4.00 \mathrm{~mm})$ and a substantial amount of spalling at the bottom side and one corner. Beam C2-C with crumb rubber (CR) had shown large amount of spalling at the bottom side and at 
corner of the beam with formation of $0.25 \mathrm{~mm} \sim 3.00 \mathrm{~mm}$ cracks along the main rebar of the beams. Beam C3-C with HDPE fiber had fewer cracks $(0.2 \mathrm{~mm} \sim 1.00 \mathrm{~mm})$ along one-fourth length of the main rebar and localized corrosion damage. All three beams were tested 11 days in corrosion environment. Beam C3-C (LWSCC+1\%HDPE) showed the superior corrosion resistance performance based on the crack width and crack pattern as well as showing no spalling.
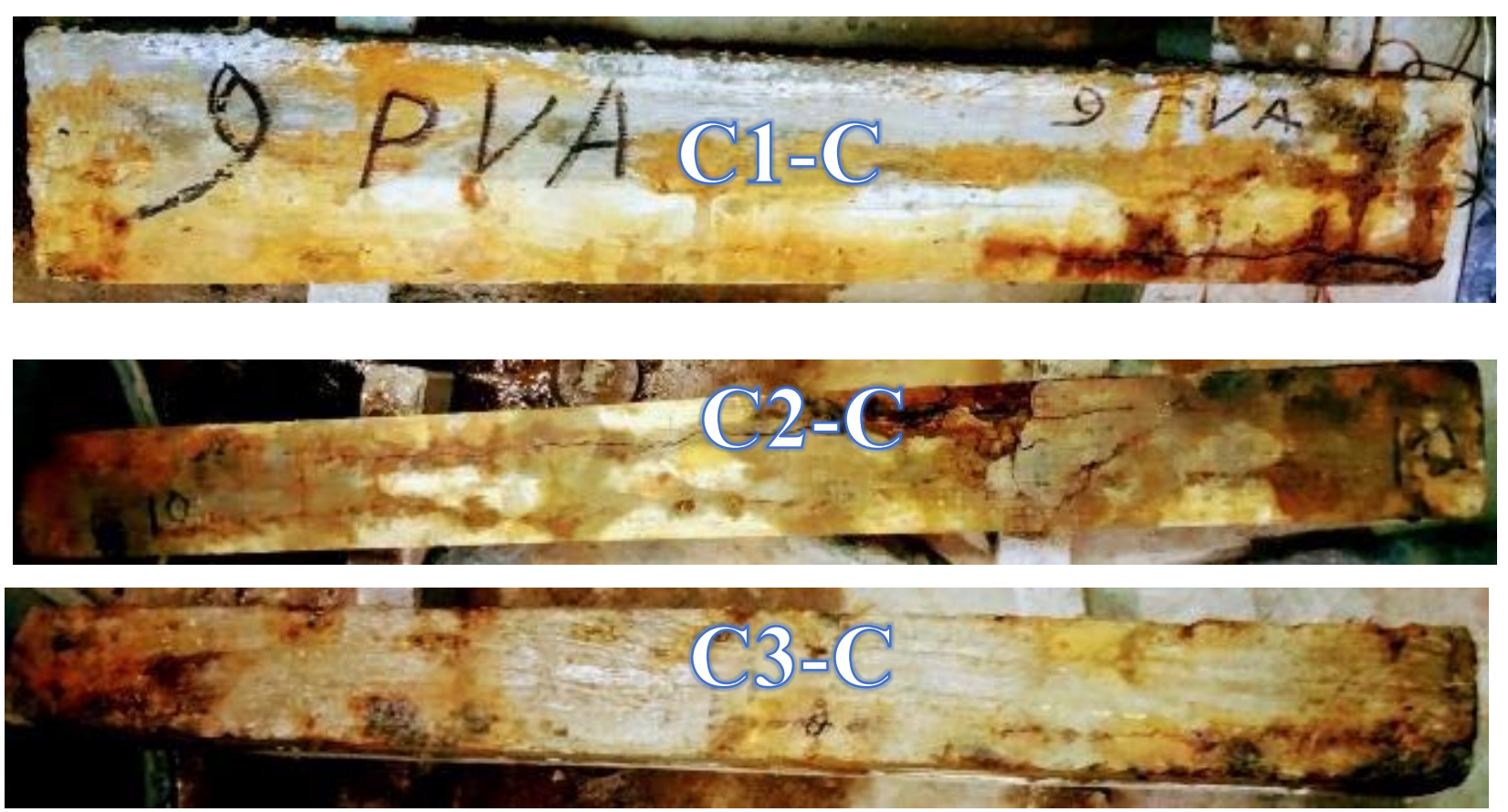

Figure 4-3: The cracks pattern and spalling of corroded beams after 11 days of corrosion test of group C 
Table 4-1: Summary of Cracks and Spalling Observations

\begin{tabular}{|c|c|c|c|c|}
\hline \multirow[b]{2}{*}{$\begin{array}{l}\text { Beam } \\
\text { No. }\end{array}$} & \multirow[b]{2}{*}{ Beam Type } & \multicolumn{3}{|c|}{ Crack and Spall observation } \\
\hline & & 7 days & 11 days & 18 days \\
\hline \multicolumn{5}{|c|}{ Full depth beams/Group A } \\
\hline A1-C & Full depth SCC & $\begin{array}{l}\text { No crack } \\
\text { shown bus } \\
\text { found at } \\
\text { corner. }\end{array}$ & $\begin{array}{l}\text { Cracks }(0.25 \sim 1.0 \mathrm{~mm}) \\
\text { Spalling found a bottom, } \\
\text { side, and upper corner. }\end{array}$ & $\begin{array}{l}\text { Test completed by } 11 \\
\text { days }\end{array}$ \\
\hline A2-C & Full depth LWSCC & $\begin{array}{l}\text { Cracks appeared } \\
(0.25 \mathrm{~mm} \sim 0.5 \mathrm{~mm})\end{array}$ & $\begin{array}{l}\text { Cracked } \quad \text { expanded } \\
(0.25 \mathrm{~mm} \sim 1.00 \mathrm{~mm})\end{array}$ & $\begin{array}{l}\text { Test completed by } 11 \\
\text { days }\end{array}$ \\
\hline A3-C & Full depth ECC & No crack looked & No crack appeared & $\begin{array}{l}\text { Small crack }(<0.2) \\
\text { appeared at the bottom } \\
\text { but side and top showed } \\
\text { no cracks and spall. }\end{array}$ \\
\hline \multicolumn{5}{|c|}{ Composite beams/Group B } \\
\hline B1-C & ECC100+SCC125 & No crack appeared & No crack appeared & $\begin{array}{l}\text { No crack found at bottom } \\
\text { side but spalling found on } \\
\text { one side and upper corner }\end{array}$ \\
\hline B2-C & ECC100+LWSCC125 & No crack appeared & No crack appeared & $\begin{array}{l}\text { No crack appeared at the } \\
\text { bottom but spall found at } \\
\text { two top corners. }\end{array}$ \\
\hline B3-C & $\begin{array}{l}\text { LWSCC+14mm ECC } \\
\text { wrapping }\end{array}$ & No crack appeared & No crack appeared & No crack appeared \\
\hline B4-C & ECC50+SCC150 & $\begin{array}{l}\text { No crack was } \\
\text { shown }\end{array}$ & $\begin{array}{l}\text { No crack showed at } \\
\text { bottom side but spalling } \\
\text { found at upper SCC part }\end{array}$ & $\begin{array}{l}\text { Test completed by } 11 \\
\text { days }\end{array}$ \\
\hline B5-C & ECC50+LWSCC150 & $\begin{array}{l}\text { No crack was } \\
\text { shown but spalling } \\
\text { found at upper } \\
\text { corner. }\end{array}$ & $\begin{array}{l}\text { No crack showed at } \\
\text { bottom side but three spot } \\
\text { corrosion damage found } \\
\text { at bottom }\end{array}$ & $\begin{array}{l}\text { Test completed by } 11 \\
\text { days }\end{array}$ \\
\hline \multicolumn{5}{|c|}{$\begin{array}{l}\text { FRLWSCC/Group C } \\
\end{array}$} \\
\hline C1-C & LWSCC $+.25 \%$ PVA & $\begin{array}{l}\text { Crack shown } \\
(0.25 \sim 1.5 \mathrm{~mm})\end{array}$ & $\begin{array}{l}\text { Cracked shown } \\
(0.25 \sim 2.5 \mathrm{~mm}) \\
\text { spalling found }\end{array}$ & $\begin{array}{l}\text { Test completed by } 11 \\
\text { days }\end{array}$ \\
\hline $\mathrm{C} 2-\mathrm{C}$ & $\mathrm{LWSCC}+1 \% \mathrm{CR}$ & $\begin{array}{l}\text { Crack shown } \\
(0.25 \sim 1.75 \mathrm{~mm})\end{array}$ & $\begin{array}{l}\text { Cracked shown } \\
(0.25 \sim 3 \mathrm{~mm}) \text { and spalling } \\
\text { found }\end{array}$ & $\begin{array}{l}\text { Test completed by } 11 \\
\text { days }\end{array}$ \\
\hline C3-C & LWSCC + 1\% HDPE & No crack appeared & $\begin{array}{l}\text { Small } \\
\text { crack }(0.25 \sim 1.00 \mathrm{~mm}) \text { and } \\
\text { local corrosion } \\
\text { damage/spot found }\end{array}$ & $\begin{array}{l}\text { Test completed by } 11 \\
\text { days }\end{array}$ \\
\hline
\end{tabular}

\subsubsection{Overal cracking observations}

Figures 4-4 and 4-5 show the side and top view of corroded beams after 18 days' corrosion test, where top corner spalling is shown in composite beams B1-C and B2-C. The Table 4-1 shows the cracks and spalling summary of the beams. The cracking width and pattern were not uniformly distributed for all FRLWSCC beams; crack and spalling increased towards the corner located 
farthest from point of casting location. Similarly, all beams showed the weaker point at both corners except full depth ECC/A3-C and LWSCC+ECC Wrapping/B3-C beams. This variation can be accredited to the fact that SCC and LWSCC beams and composite beams were cast from the mid-point and allowing these flowable self-consolidating concrete to reach the ends by their own weight. The weight of falling concrete was enough for self-compaction during casting period below the casting point but not enough for the far end, needed some extra compaction at corner or far end due to constraining of concrete movement in the formwork. Hence, SCC and LWSCC showed the porous and weak corrosion performance at the corner points those were far away from the casting point.

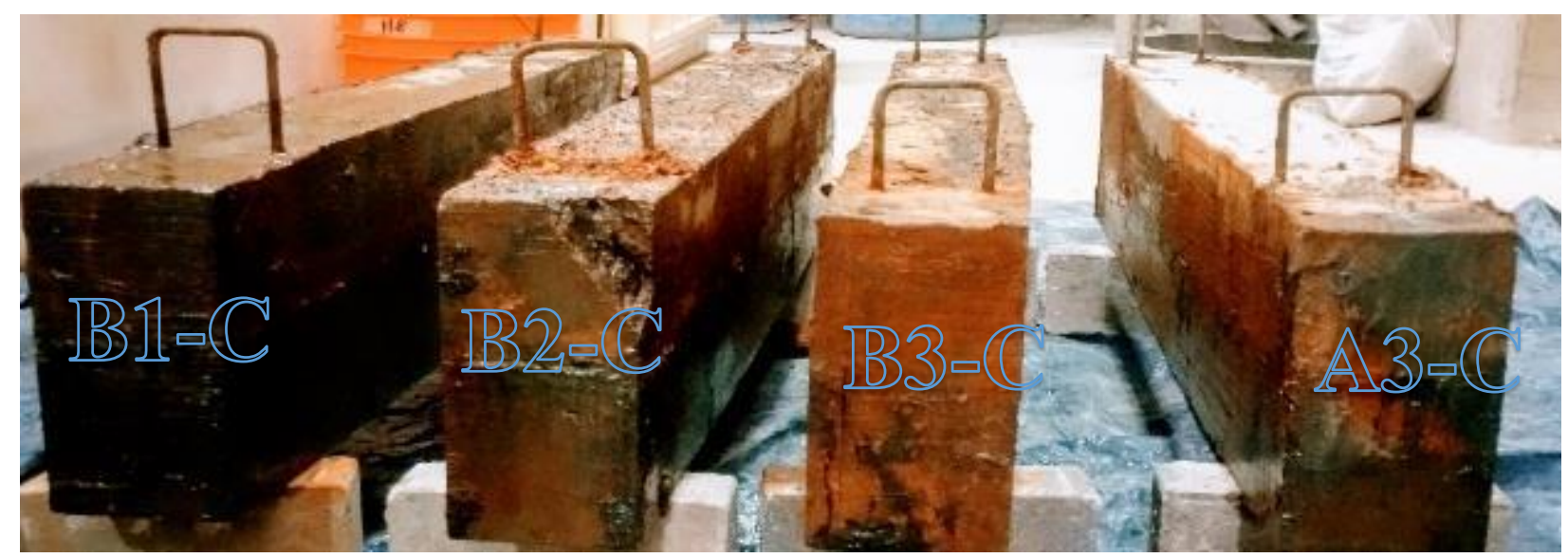

Figure 4-4: Side view of beams after 18 days of corrosion test of B1-C, B2-C, B3-C and A3-C

Full depth SCC beam/A1 exhibited cracks at the bottom, large spalling and sustained 11 days in corrosion test. Full depth LWSCC/A2-C beam had cracks, spalling and sustained 11 days' corrosion test (reached to desired theoretical mass loss), on the other hand LWSCC + ECC wrapping beam/B3-C had no crack, no spalling and sustained 18 days corrosion test. ECC wrapping protected the beam rebar due to its denser matrix and reduced chloride permeability. 


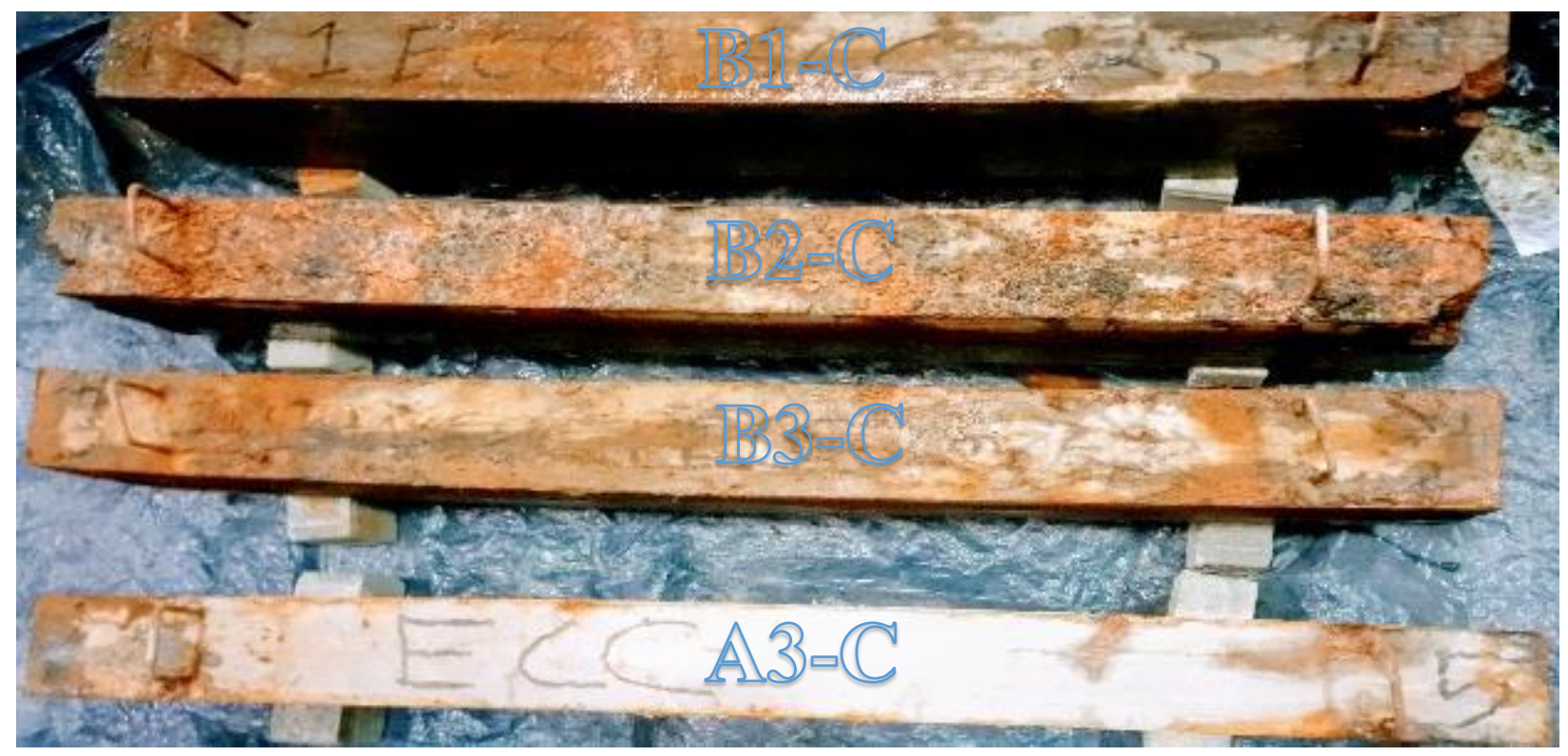

Figure 4-5: Top view of corroded beams after 18 days' corrosion test: B1-C, B2-C, B3-C \& A3-C However, composite beams B1-C (ECC100+SCC150) and B4 (ECC50+SCC150) had no cracks at the bottom. In addition, composite beam B1-C sustained 18 days in corrosion test. The beams B1-C and B2-C had 45mm effective cover thickness, whereas the other beams had $20 \mathrm{~mm}$ effective cover thickness. This results indicated higher cover ensured the protection of steel from corrosion in concrete and ECC layer covering fully the longitudinal reinforcement as well as ECC wrapping covering LWSCC core were effective in increasing the corrosion resistance.

\subsubsection{Time-dependent corrosion test results}

\subsubsection{Current results}

The accelerated corrosion current measured by computerized data accusation system, which recorded the passing current in every minute's interval for each beam. Figures 4-6 show the relationship of average current flow in milli-ampere for all beams. Figure 4-7 shows the current flow- immersion time in the hour after 18 days of corrosion test of beams (B1-C, B2-C, B3-C and A3-C). Figure 4-8 shows 11 days' current flow of four beams (A1-C, A2-C, B4-C, B5-C) and Figures 4-9 shows 11 days current flow of FRLWSCC beams. These tests used 30V DC power supply and variable current flow with a maximum limit of up to $5 \mathrm{Amp}$. The average current density of this experiment was 0.76 milliamps $/ \mathrm{cm}^{2}$. 


\subsubsection{Current results for full depth group $A$ beams}

Figures 4-6, 4-7 and 4-8 show the average current flow and the current flow vs immersion time graph. Beams SCC/A1-C, ECC/A3-C showed an initial low current flow and followed by a gradual increase. LWSCC/A2-C beam showed high current flow from the beginning. Initially, low current flow is an indication of the formation of the passive film around the reinforcing steel bar by sound concrete, which protects the steel from corrosion. This protection is deteriorated by introducing too much chloride. Then a depassivation occurred, when depassivation of the steel occurred, corrosion started and then the rate of corrosion increases significantly as reported by Cornet et al. (1968). On the other hand, LWSCC beam passed the high current from the very beginning due to its porous structure could not make a strong passive film around the rebar. Beam A2-C (Full depth LWSCC) exhibited higher average current values $(3116 \mathrm{~mA})$ during the whole test period among the full depth beams (A1-C, A2-C and A3-C) and Full ECC/A3-C showed lower current flow $(1783 \mathrm{~mA})$. There for full depth ECC beams exhibited the best corrosion resistance by forming passive layer around reinforcement early (as indicated by low current flow) followed by full depth SCC and LWSCC beams. The lower current passing through the concrete specimens is an indication of the higher resistance 


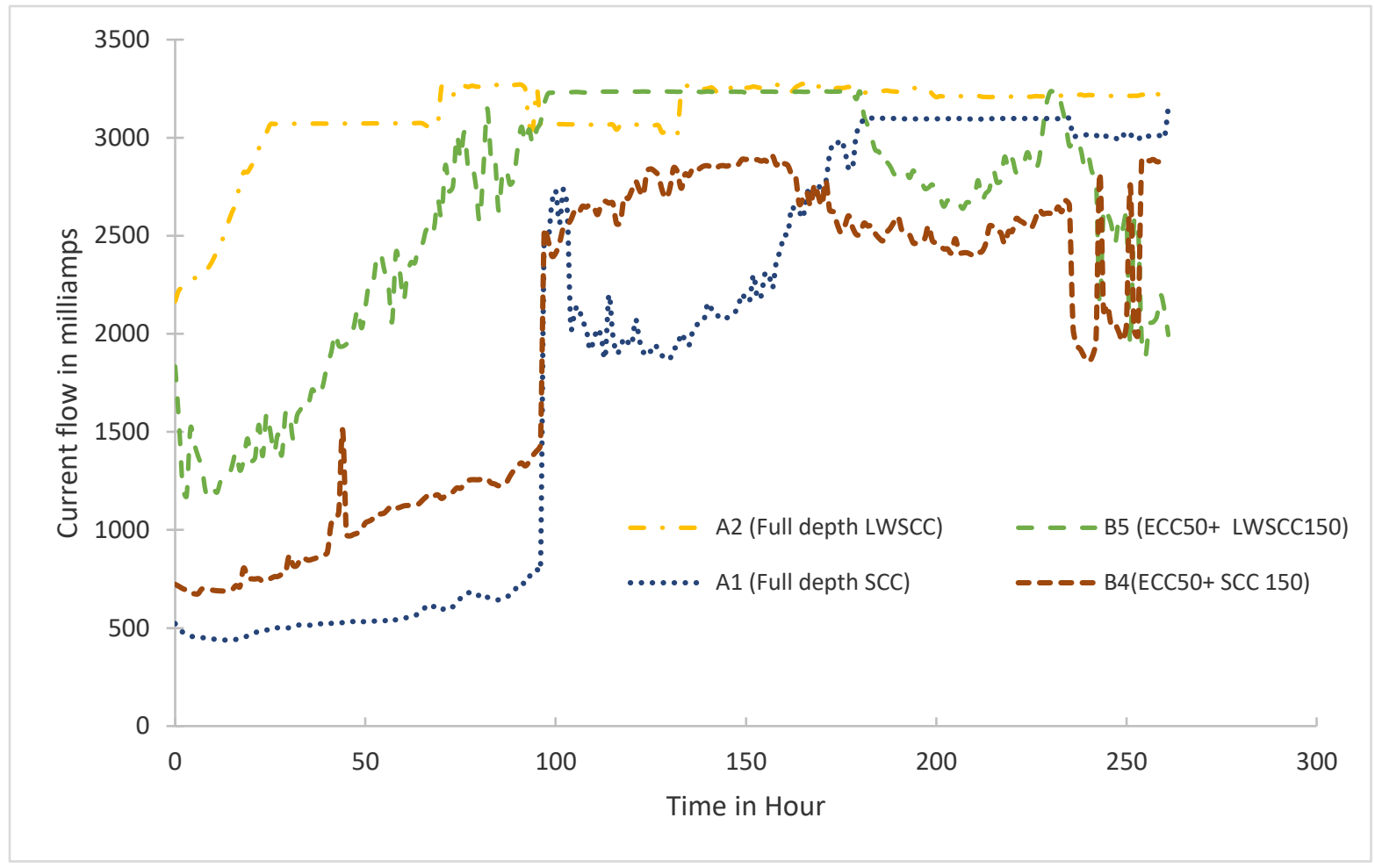

Figure 4-6: Current flow-immersion time curve for 11 days' corrosion test

performance of the concrete. The permeability of the concrete is the main factor influencing the concrete durability and resistivity, increase the permeability increase chloride induce corrosion (Bog \& Topçu, 2012). 


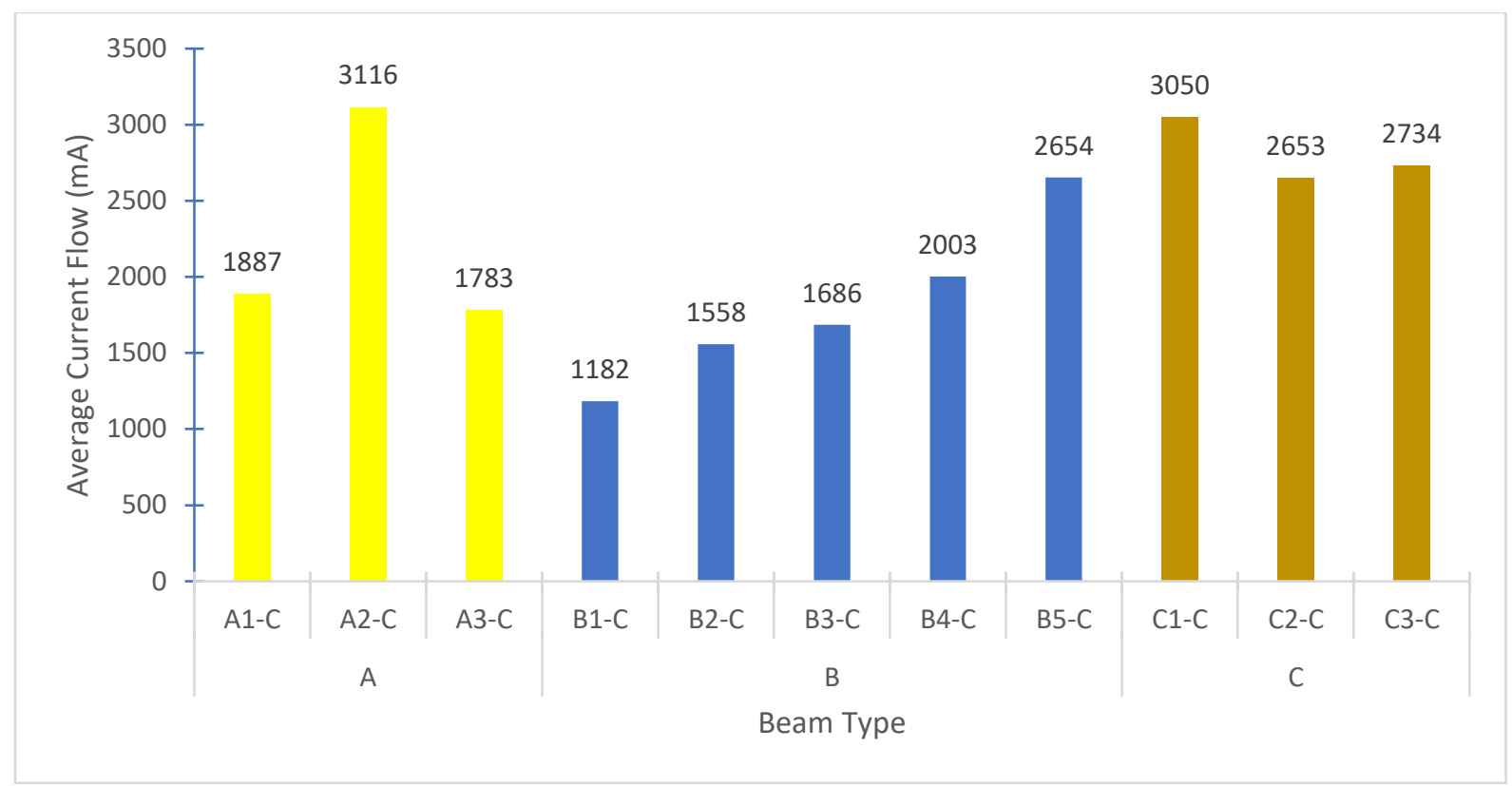

Figure 4-7: Average current flow for all Eleven corroded beams

\subsubsection{Current results for group B composite beams}

Figures 4-7 and 4-8 show average current flow and current vs immersion time graphs. Beam B1$\mathrm{C}$ exhibited lower average current (1182 milliamperes) and beam B5-C exhibited high average current (2654 milliamperes). Beam B1(ECC100+SC125) passed the low average current due to its main rebar was embedded by higher thickness of ECC layer $(100 \mathrm{~mm})$ than beams B3-C, B4-C and B5-C. Also, Beams B2-C (ECC100+LWSCC125) had 100 mm ECC layer - LWSCC passed higher current due to its high porosity. This shows that an increase the thickness of ECC layer increased the corrosion resistance of composite beams. 


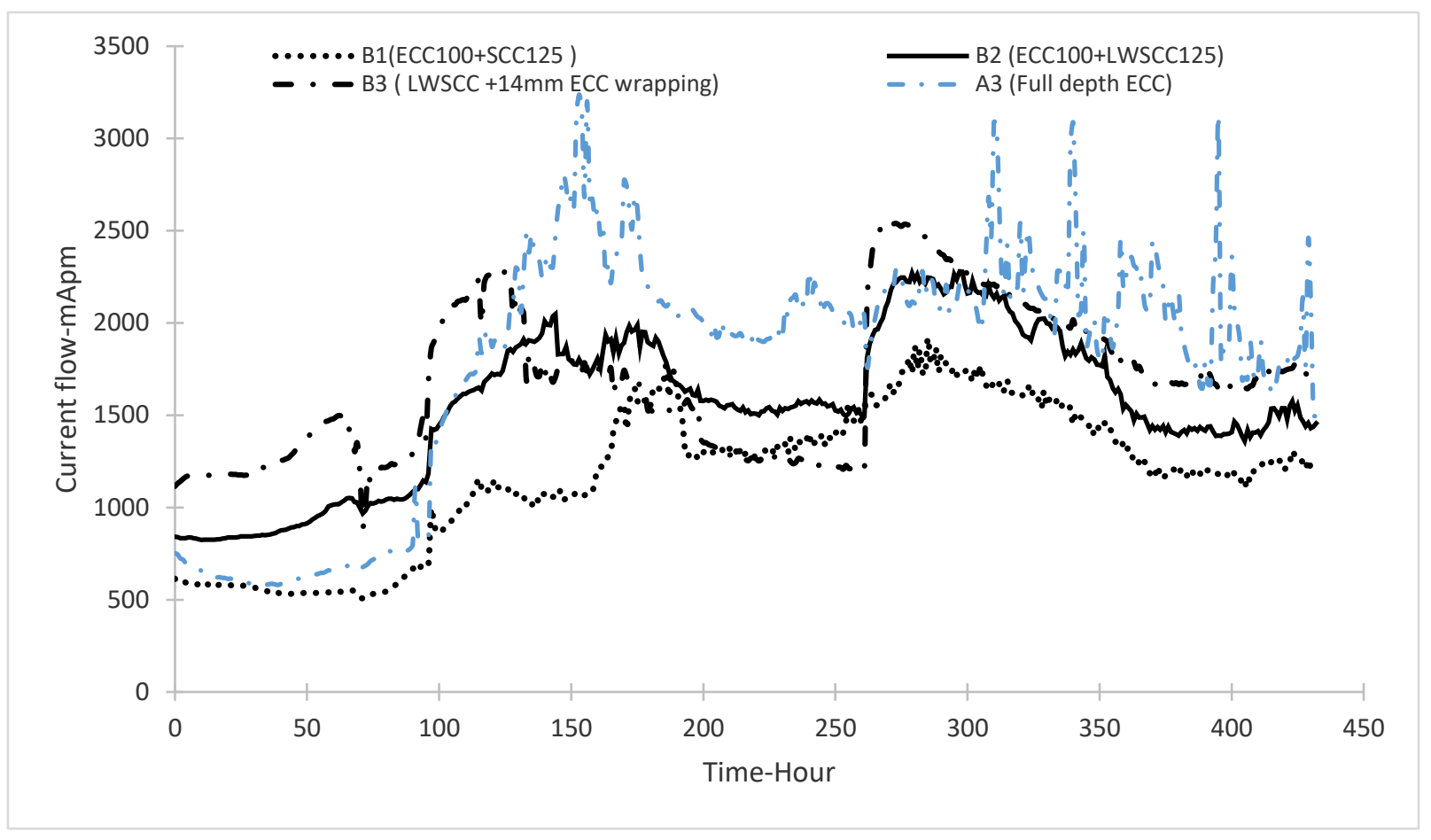

Figure 4-8: Current flow-immersion time curve for 18 days' corrosion test

\subsubsection{Current results for group C FRLWSCC beams}

Figures 4-7 and 4-9 show average current flow and current vs immersion time graphs. All FRLWSCC beams carried the higher current from the start to the end except beam C2-C (LWSCC $+1 \%$ Crumb rubber 'CR'). Initial current flow of Beam FRLWSCC-CR/C2-C decreased then gradually increased till three days then exhibited steady current flow till the end of the test. Crumb rubber fiber created protection for chloride ion penetration to the rebar initially. Hence beam FRLWSCC-CR/C2-C carried the lowest current (2653 milliamperes) exhibiting higher corrosion resistance than FRLWSCC-HDPE/C3 carried 2734 milliamperes current and LWSCC-PVA/C1-C passed highest 3050 milliamperes current during the test period. 


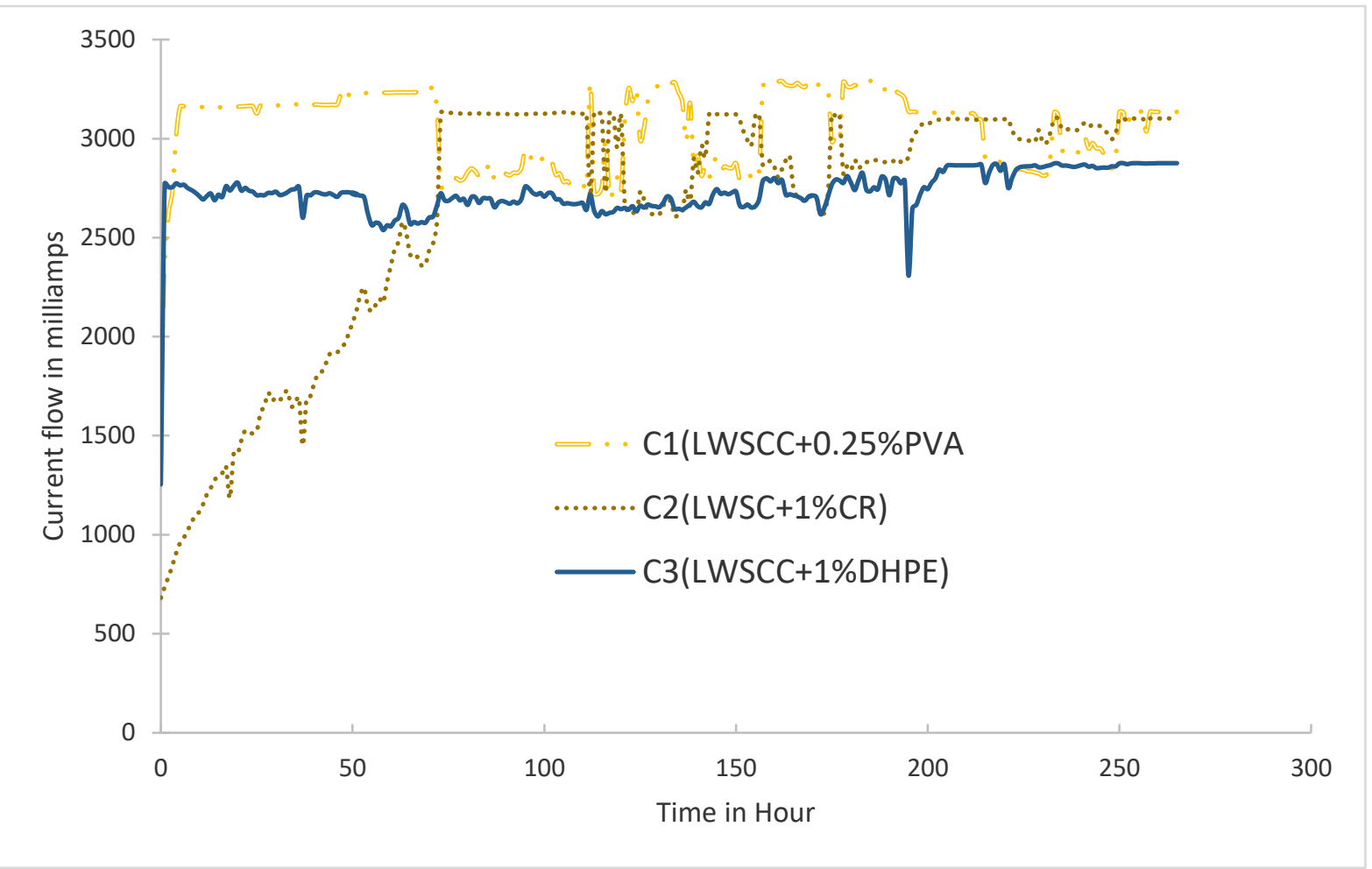

Figure 4-9: Current flow-time immersion curves of FRLWSC beams

\subsubsection{Overall current results}

The point of first increase of the slope, in the current flow-immersion time curve, indicates the corrosion commencement. Also, this slope indicates the rate of corrosion. Full depth LWSCC beam LWSCC/A2-C showed constant current flow that means the rate of corrosion was constant for these beams. Figures 4-6 and 4-8 show the sudden change of current flow after 100-hour corrosion test because the test tub was cleaned and replaced the new $\mathrm{NaCl}$ solution to maintain the $\mathrm{P}^{\mathrm{H}}$ of the solution. Non-epoxy coated stirrups were used in this research because $6 \mathrm{~mm}$ epoxy coated rebars were not available on the market. Hence higher current flow exhibited for all tested beam rather than expectation due to some current flowed through the stirrups and top rebar as well. Stirrups became corroded before then main longitudinal rebar due to less concrete cover thickness. Figure 4-8 shows full depth SCC/A1-C and a composite beam ECC50+SCC150/B4-C which exhibited a sudden jump in the current flow-time curve after a relative slope compared to others beams. This sudden change of current-time curves was the indication of the concrete spalling in full depth SCC-A1-C and composite beam B4-C. 


\subsubsection{Half-cell potential measurements}

The half-cell potential test was performed according to ASTM C876 for eleven beams. Figure 410 shows the half-cell potential measuring device. Four points were selected on left (1), right (1) and bottom (2) $50 \mathrm{~mm}$ from the edge of the beam and testing continued @200mm interval along the beams as described in Chapter 3. The half-cell potential test can only represent the probability of corrosion for un-corroded beams, while the test might not give a good sign for already corroded beams. Table 4-2 demonstrates the results of average half-cell potential reading (V) at 24 points of eleven tested beams. The half-cell potential test results presented the probability of corrosion not actual corrosion.

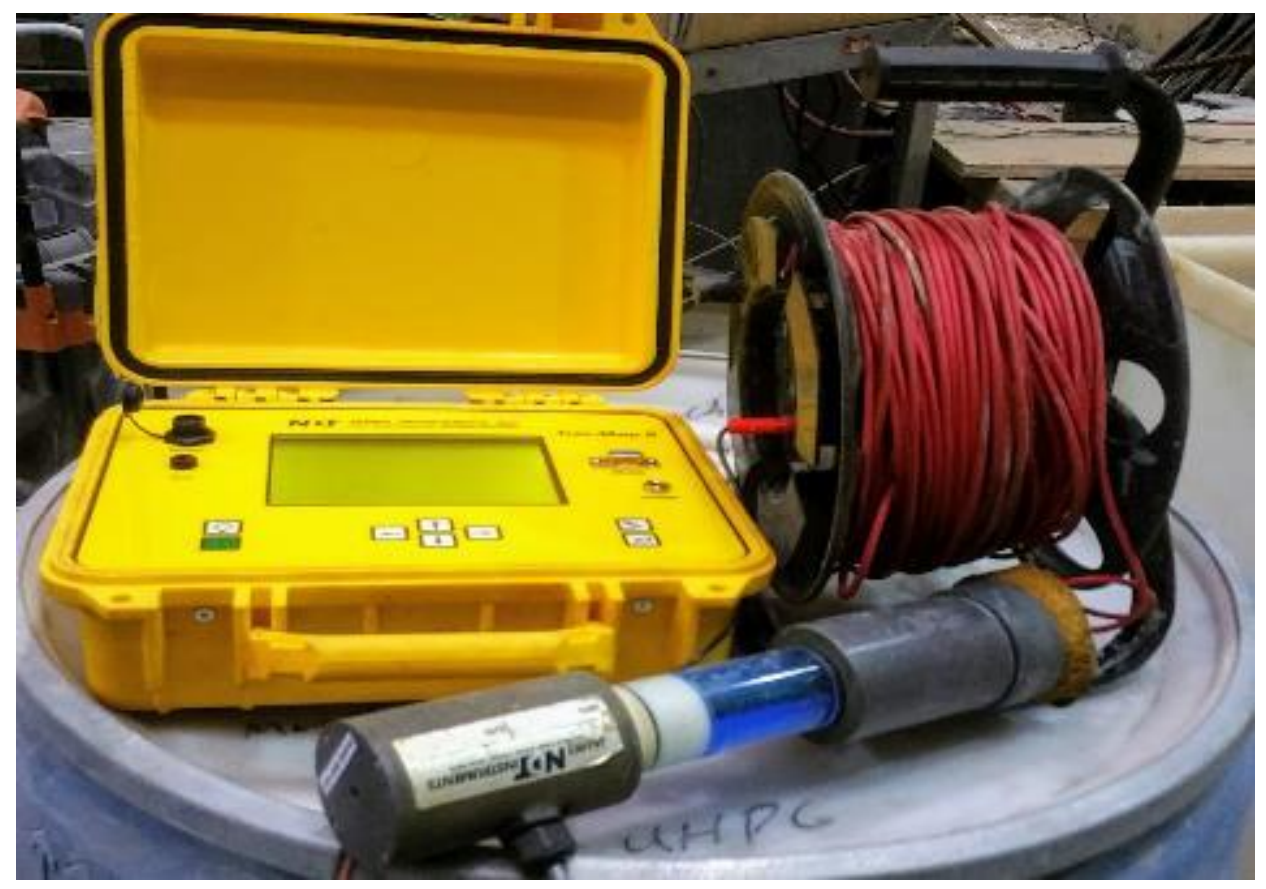

Figure 4-10: Half cell potential measuring tools

The half-cell potential (HCP) test used can only represent the probability of corrosion for uncorroded beams, it may not give good indication accurate result. Table 4-2 demonstrate the results of average half-cell potential reading (Volts) at 24 points of eleven tested beams. The half-cell potential test results presented the probability of corrosion not actual corrosion (ASTM C876, 2016) and provided three categories of corrosion stages A, B and C as per Table 4-2 depending on the HCP ranges. 
Table 4-2:Average half-cell potential reading along the bottom side and perimeter of the beams

\begin{tabular}{|c|c|c|l|}
\hline Specimen & $\begin{array}{l}\text { Avg. HCP } \\
\text { Reading } \\
\text { (Volts) }\end{array}$ & Category & Corrosion Condition/Descriptions \\
\hline \multicolumn{5}{|c|}{ Group - A } \\
\hline A1-C (Full-depth SCC) & -0.28 & C & Corrosion activity over this area is uncertain \\
\hline A2-C (Full-depth LWSCC) & -0.29 & B & $90 \%$ chance corrosion is occurring in this area \\
\hline A3-C (Full-depth ECC) & -0.28 & C & Corrosion activity over this area is uncertain \\
\hline \multicolumn{5}{|c|}{ Group - B } \\
\hline B1-C (ECC100+SCC125) & -0.26 & C & Corrosion activity over this area is uncertain \\
\hline B2-C (ECC100+LWSCC125) & -0.27 & C & Corrosion activity over this area is uncertain \\
\hline B3-C(ECC100+LWSCC125) & -0.27 & C & Corrosion activity over this area is uncertain \\
\hline B4-C(ECC50+LWSCC150) & -0.28 & C & Corrosion activity over this area is uncertain \\
\hline B5-C(ECC50+LWSCC150) & -0.27 & C & Corrosion activity over this area is uncertain \\
\hline \multicolumn{5}{|c|}{ Group - C } \\
\hline C1-C (LWSCC+0.25\%PVA) & -0.34 & B & $90 \%$ chance corrosion is occurring in this area \\
\hline C2-C(LWSCC+1\%CR) & -0.38 & A & $90 \%$ chance corrosion is occurring in this area \\
\hline C3-C(LWSCC+1\% HDPE) & -0.33 & B & $90 \%$ chance corrosion is occurring in this area \\
\hline
\end{tabular}

\subsubsection{Half-cell potential for group A beams}

Table 4-2 shows the average half-cell potential (HCP) all over the corroded beams and Figure 411 shows average HCP vs immersion time curves. All beams exhibited close HCP potential: -0.28 $\mathrm{V}$ for SCC/A1-C, $-0.29 \mathrm{~V}$ for $\mathrm{LWSCC} / \mathrm{A} 2-\mathrm{C}$ and $-0.28 \mathrm{~V}$ for $\mathrm{ECC} / \mathrm{A} 3-\mathrm{C}$ beams. The results indicated that all beams might be corroded at the same level. HCP value less than -0.21 volts indicates the corrosion start or uncertain. Therefore, full depth LWSCC/A2-C beam initiated corrosion before the full depth SCC and full depth ECC beam. 


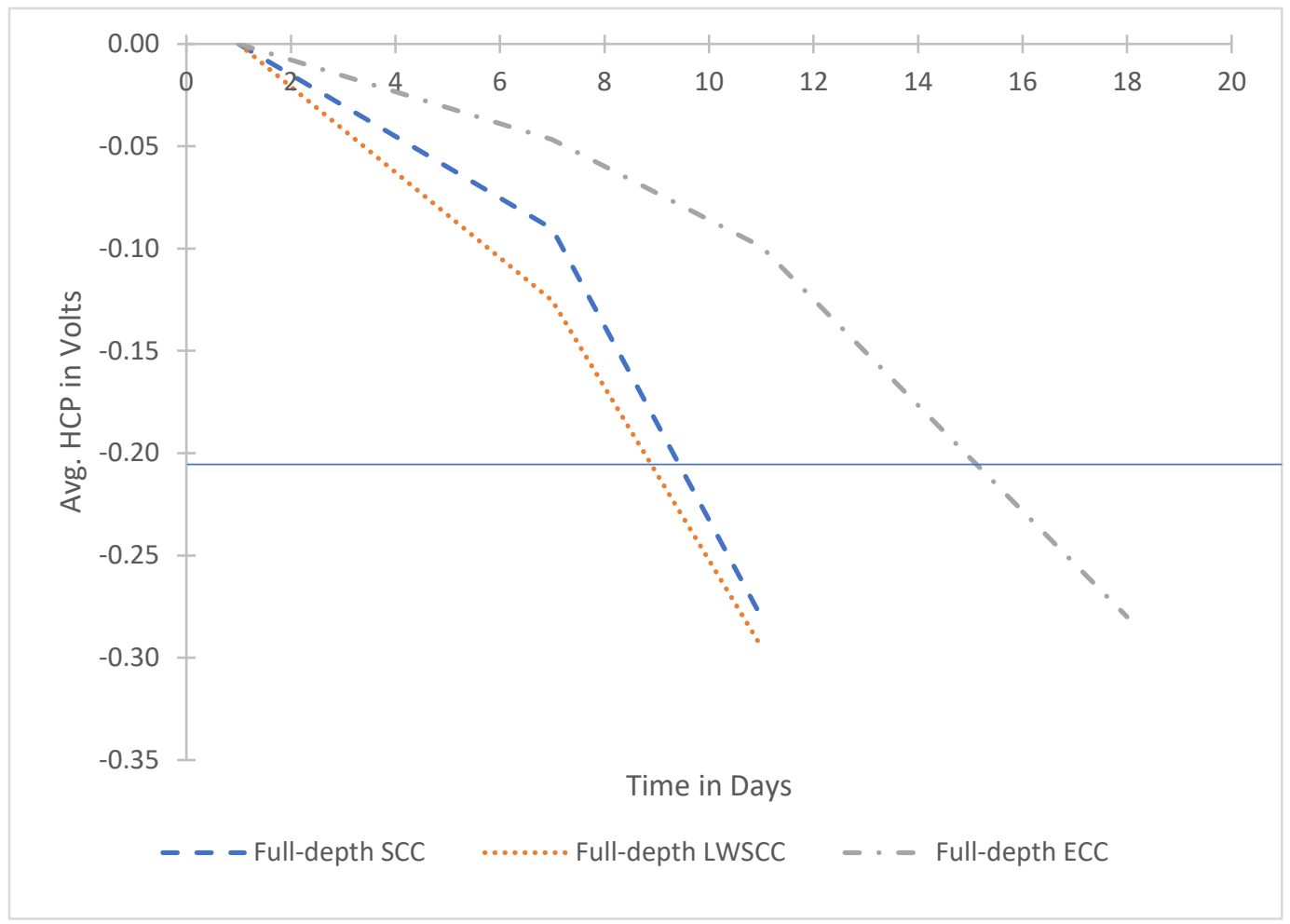

Figure 4-11: Average HCP vs immersion time curve for corroded beams of group A

\subsubsection{Half-cell potential for group B beams}

Table 4-2 presents the average HCP all over the corroded beams and Figure 4-12 shows HCP vs immersion time curves of group B beams. All beams exhibited the corrosion status uncertain in the category $\mathrm{C}$, but $\mathrm{HCP}$ values were found to be greater than -0.26 volts. That indicated some corrosion happen on the rebar in the concrete. However, Figure 4-13 shows that beams B4 (ECC50+SCC150) and B5 (ECC50+SCC150) initiated corrosion before the corrosion initiation in the beams B1-C (ECC100+125SCC), B2-C (ECC100+LWSCC125) and B3-C (LWSCC+ECC wrapping). The HCP results showed that higher thickness of ECC layer and ECC wrapping increased the corrosion resistance performance of the composite beams. 


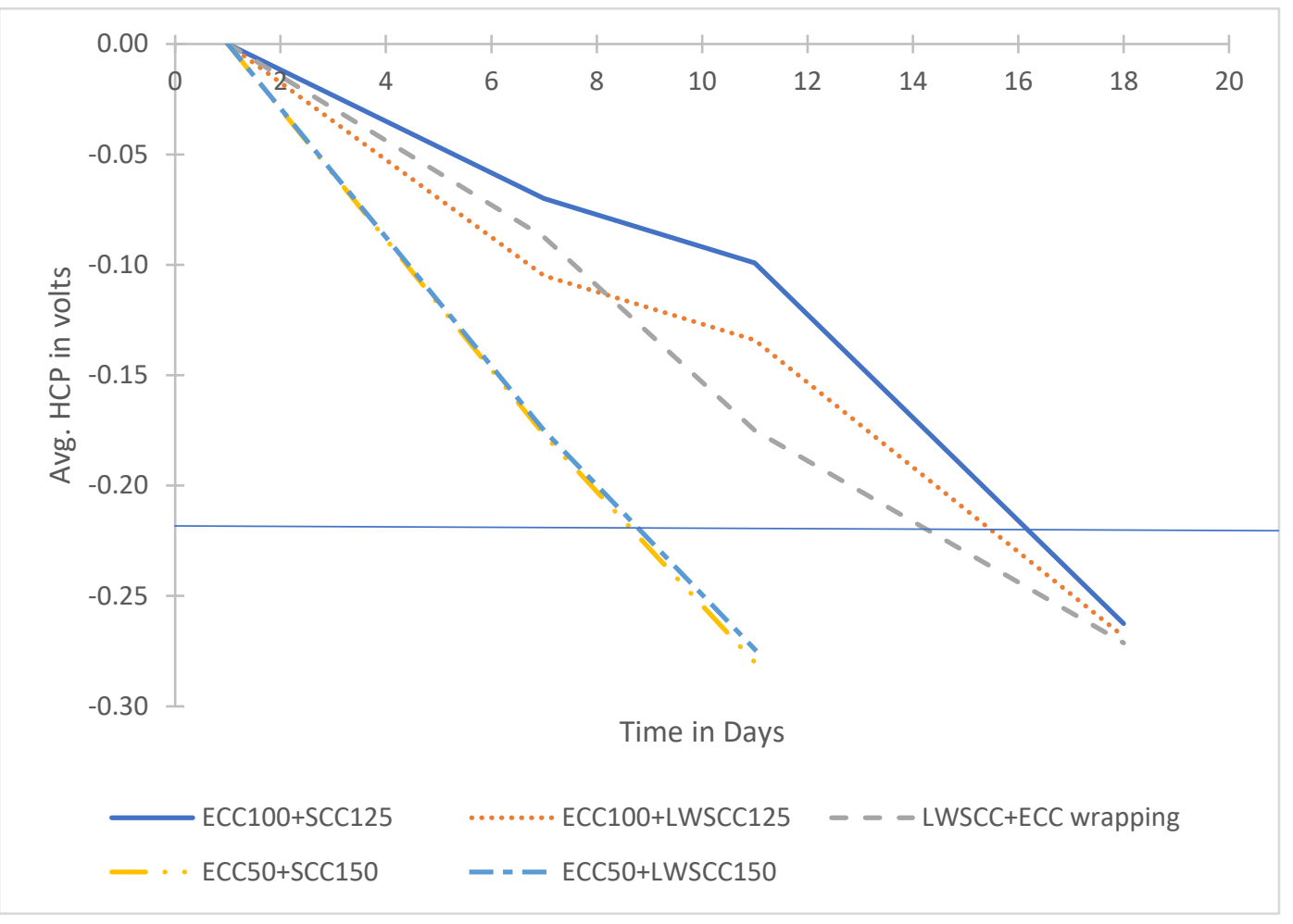

Figure 4-12: Average HCP vs immersion time curve for corroded beams of group B

\subsubsection{Half-cell potential for group $C$ beams}

Table 4-2 shows the average HCP all over the corroded beams and Figure 4-13 presents average $\mathrm{HCP}$ vs immersion time curve of group $\mathrm{C}$ beams. In Table 4-2, the HCP readings for all of the beams are located $\mathrm{A}$ and $\mathrm{B}$ categories in the case of severe corrosion and showed a higher than $90 \%$ chance for corrosion to occur. Figure 4-13 shows that Beam C1-C (LWSCC+0.25\%PVA) started corrosion (crossed 0.210 volts in HCP reading) before the beams LWSCC-CR/C2-C and LWSCC-HDPE/C3-C. The result indicated PVA fiber increased the chloride ion permeability of FRLWSCC. Beam C3-C (LWSCC+1\% HDPE) had shown superior corrosion performance in terms of HCP than $\mathrm{C} 1-\mathrm{C}$ (LWSCC+0.25\%PVA) and C2-C (LWSCC+1\%CR) beams.

\subsubsection{Overall Half-cell potential for all groups}

All FRLWSCC beams in Group exhibited lower (negative higher) level of HCP values compared to all others beams. One of the beam was in category A (confirming the high level of corrosion), three of the beams were in category B (confirming the high level of corrosion) and seven of the beams were in category $\mathrm{C}$, which is also corrosion category but uncertain for corrosion severity. There were two main reasons for this high probability of corrosion: 
1. The relatively high percentage of the humidity and slat inside the tested beams.

2. The thin $14 \mathrm{~mm}$ concrete clear cover above the rebars, because test specimens were not too big. Figure 4-14 shows typical HCP vs immersion time curves at six different points of a beam. Close values of the HCP readings were found on each beam in the longitudinal and transverse directions (Figure 4-14), which was mainly because of the small size of the specimens, and the $1.2 \mathrm{~m}$ satisfactory spacing required for the half-cell potential test readings, according to ASTM C 876 15 (2016)

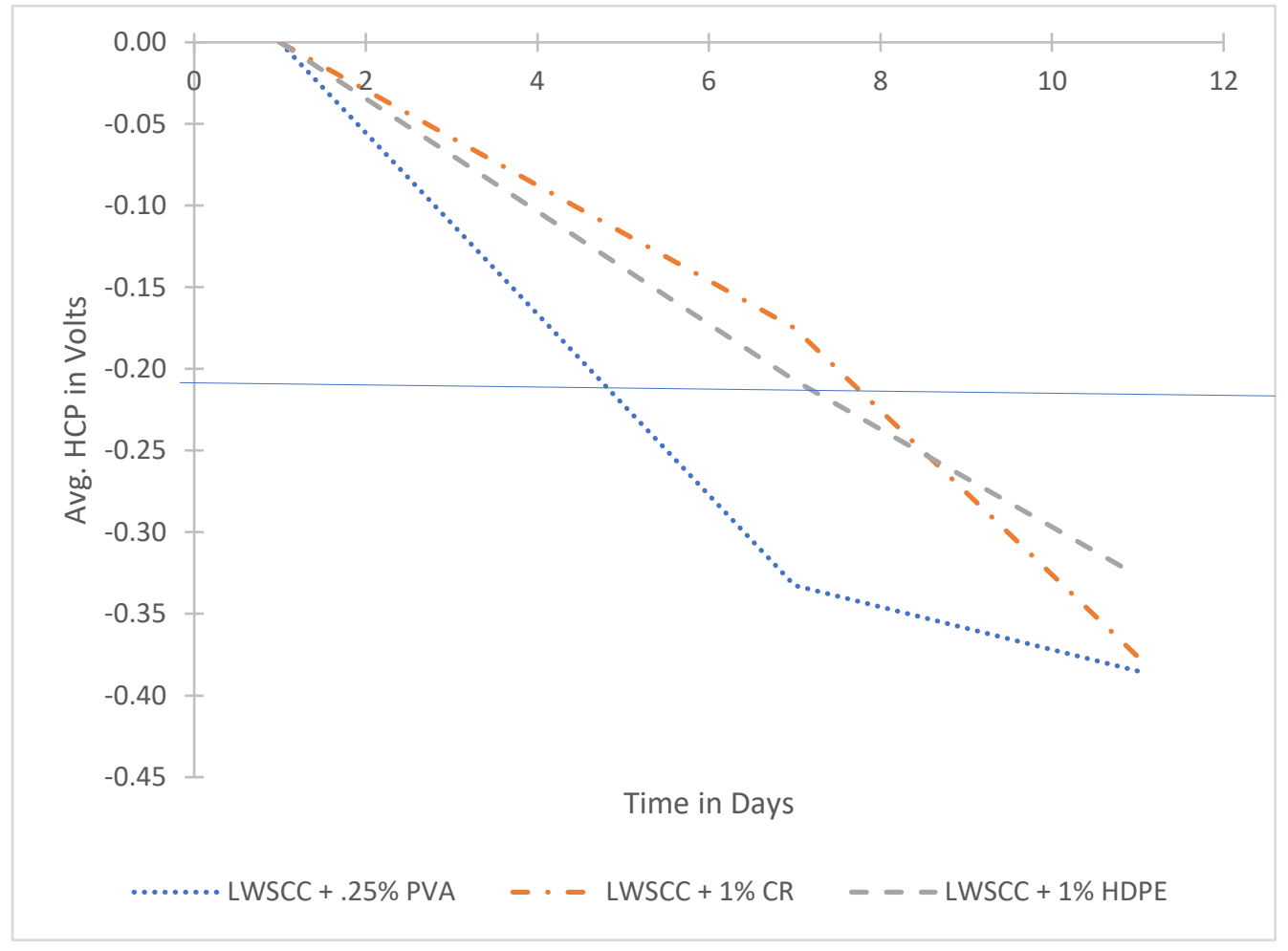

Figure 4-13: Average HCP vs immersion time curve of corroded beams of group C 


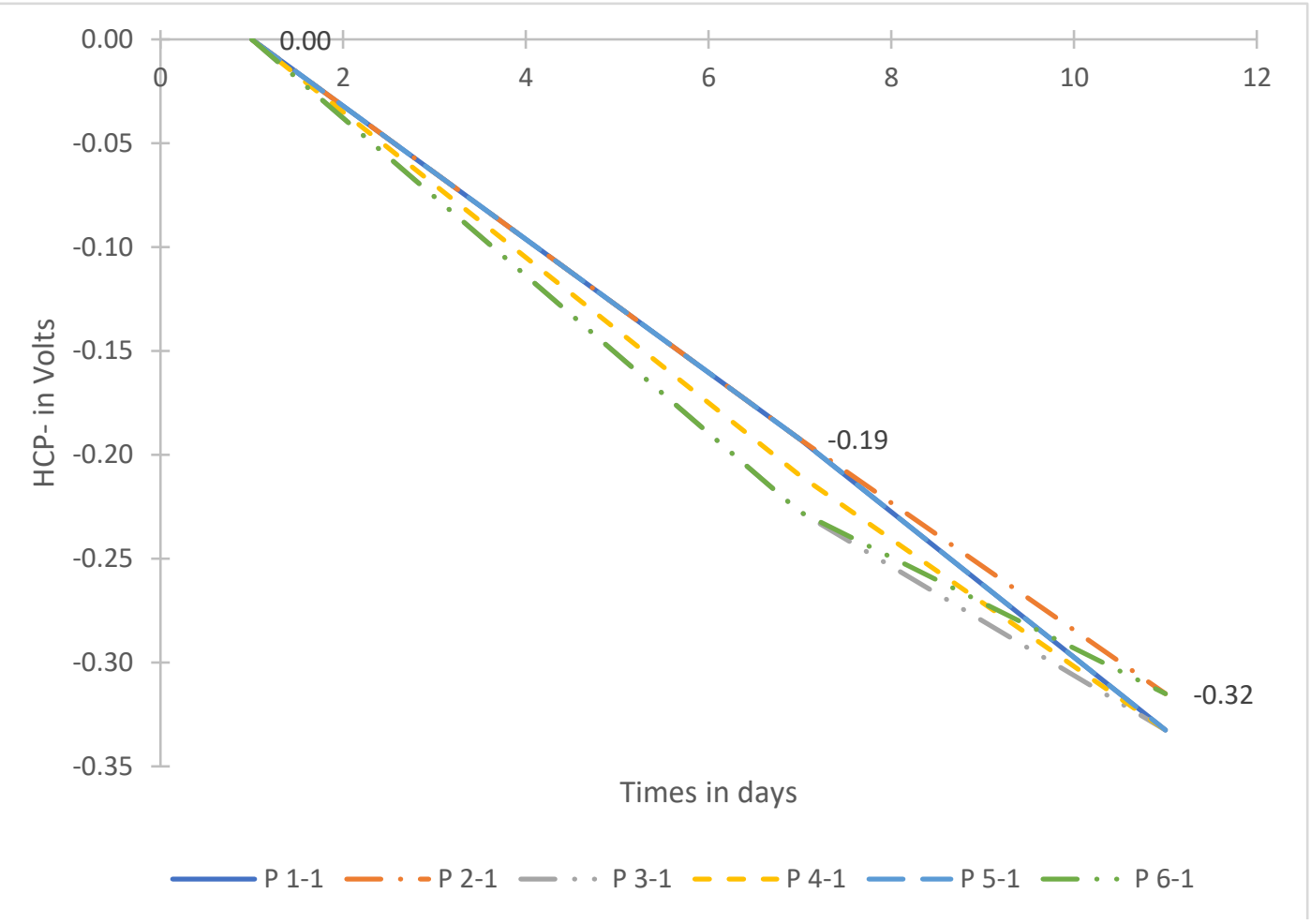

Figure 4-14: HCP at different points vs immersion time curves of beam C3-C (LWSCC+1\% HDPE)

\subsection{After corrosion test results}

All corroded beams were broken by a jackhammer to extract the main rebars from corroded beams. The rusty rebars were cleaned and measured for mass loss and diameter loss. The chloride ion permeability, rebar mass loss, reduction of bar diameter, crack width results are analyzed and summarized in Table 4.3.

\subsubsection{Chloride ion permeability, mass loss, and bar diameter reduction of group A beams}

Table 4-3 shows chloride ion permeability of concretes as per (Celasun, 2017) and (Siad, et al., 2015), rebar mass loss, maximum crack width and reduction of bar diameter along the length. The results confirmed the finding of the half-cell and current monitoring (11 days and 18 days), mass loss and crack width results, which indicated the superior corrosion resistance performance of fulldepth beam ECC/A3-C in protecting steel bars from corrosion among the group A beams. In addition, full-depth ECC beam exhibited best corrosion resistance performance based on actual 
mass loss $27.23 \%$ and strength loss $11.75 \%$ (which will be discussed later) among group A beams. Regarding the bar diameter loss, ECC/A3-C showed higher bar diameter after corrosion than the bar diameters of SCC/A1-C and LWSCC/A2-C beams, due to 'very low' ECC permeability.

Table 4-3: Summary of rebar mass loss, maximum crack width and the reduction of bar diameter along the beam length/perimeter

\begin{tabular}{|c|c|c|c|c|c|c|c|c|c|}
\hline $\begin{array}{l}\text { Beam } \\
\text { Group }\end{array}$ & $\begin{array}{l}\text { Beam } \\
\text { No. }\end{array}$ & $\begin{array}{l}\text { Chloride } \\
\text { permeability } \\
\text { of concrete } \\
\text { around the } \\
\text { main bar }\end{array}$ & $\begin{array}{c}\% \\
\text { Actual } \\
\text { mass } \\
\text { loss }\end{array}$ & $\begin{array}{c}\% \\
\text { Strength } \\
\text { loss }\end{array}$ & $\begin{array}{c}\% \\
\text { Theoretical } \\
\text { Mass loss }\end{array}$ & $\begin{array}{l}\text { days } \\
\text { of } \\
\text { curre } \\
\text { nt } \\
\text { flow }\end{array}$ & $\begin{array}{c}\text { Min } \\
\text { bar dia } \\
\text { after } \\
\text { corrosi } \\
\text { on } \\
(\mathrm{mm}) \\
\end{array}$ & $\begin{array}{l}\text { Maximum } \\
\text { crack } \\
\text { width } \\
\text { along the } \\
\text { bar }(\mathrm{mm})\end{array}$ & $\begin{array}{l}\text { Maximum } \\
\text { crack width } \\
\text { along the } \\
\text { stirrup }(\mathrm{mm})\end{array}$ \\
\hline \multirow{3}{*}{ A } & A1-C & Low & 33.17 & 29.46 & 31.76 & 11 & 8.4 & Spalling & Spalling \\
\hline & A2-C & Low & 31.93 & 13.38 & 36.44 & 11 & 9 & 0 & 0 \\
\hline & A3-C & Very low & 27.23 & 11.75 & 38.65 & 18 & 9.8 & 1.5 & 0 \\
\hline \multirow{5}{*}{ B } & B1-C & Very low & 30.51 & 30.43 & 32.94 & 18 & 10 & 0 & $\begin{array}{l}\text { Spalling at } \\
\text { both end }\end{array}$ \\
\hline & B2-C & Very low & 32.86 & 23.90 & 37.39 & 18 & 9.6 & 0 & $\begin{array}{l}\text { Spalling at } \\
\text { one end }\end{array}$ \\
\hline & B3-C & low & 38.43 & 16.05 & 44.95 & 18 & 8.0 & 0 & 0 \\
\hline & B4-C & Very low & 31.81 & 15.03 & 33.71 & 11 & 10 & 3 & 1 \\
\hline & B5-C & Very low & 29.46 & 29.74 & 36.66 & 11 & 10 & 0 & 0.5 \\
\hline \multirow{3}{*}{ C } & C1-C & Low & 40.87 & 37.70 & 46.19 & 11 & 7 & 0 & 1 \\
\hline & $\mathrm{C} 2-\mathrm{C}$ & Low & 36.88 & 40.87 & 45.40 & 11 & 6 & 2.5 & $\begin{array}{l}2 \text {, and } \\
\text { spalling }\end{array}$ \\
\hline & C3-C & Moderate & 27.41 & 15.88 & 36.79 & 11 & 8 & 1 & 0 \\
\hline
\end{tabular}

\subsubsection{Chloride ion permeability, mass loss, and bar diameter reduction of group B beams}

Table 4-3 shows that beam B1-C/(ECC100 + SCC125) exhibited good corrosion resistance performance (mass loss $30.51 \%$, flexure strength loss $30.43 \%$ and duration of the corrosion test 18 days) among all composite beams B1-C, B2-C, B3-C, B4-C, and B5-C. All beams in group B except /B3-C (with ECC wrapping) all rebars were embedded in ECC layer which had very low permeability. The main rebar of beam B3-C (ECC wrapping) was embedded in between ECC (very low permeability) and LWSCC (low permeability) layer. Therefore over all permeability was considered as low and the beam exhibited higher rebar mass loss $38.43 \%$. Composite beam B3 (LWSCC+ECC wrapping) showed less strength loss of $16.05 \%$ as less deteriorated ECC wrapping contributed to the flexure strength. On the other hand current and chloride ion entered the beam through the both side of the beam. 


\subsubsection{Chloride ion permeability, mass loss, and bar diameter reduction of group $\mathrm{C}$ beams}

Table 4-3 shows that beam C3-C with HDPE fiber showed superior performance among all the FRLWSCC beams in Group C. HDPE fiber helps to decrease the porosity of concrete and decrease the permeability of the chloride ions. Though, previous researchers had shown that FRLWSCC with HDPE fiber had moderate permeability. However, the results of this study supported the better corrosion resistance performance of $\mathrm{C} 3-\mathrm{C}$ beam in terms of low crack width, no spalling and low rebar diameter loss compared to other beams in group $\mathrm{C}$ made of CR and PVA fiber. This issue needs to be addressed and further study is required.

In general, very low chloride ion permeability helps to increase the corrosion resistance performance of the concrete. Overall beam A3-C (full depth ECC) showed superior corrosion resistance performance regarding mass loss, strength loss and duration corrosion test. Half-cell potential was relatively high at the corner point of the beam. This results indicated the spalling of the concrete cover at the corners matched the results of the half-cell potential test during the corrosion test-time monitoring. In addition, it indicated that self-consolidating concrete was less compacted at corner or end of the beams and exhibited high chloride ion permeability.

\subsection{Comparison of theoretical and actual corrosion mass loss of rebars}

The actual mass was founded after cleaning of corroded longitudinal rebar. And, the theoretical corrosion mass loss was calculated by Faraday's Mass loss Equation 3.1 on the amount of current flow through the main rebar. The calculated/theoretical mass loss was compared to the actual mass loss for each tested beam (Figure 4-15). The results show that actual mass loss was less than the theoretical mass loss for all beams except A1-C (full depth SCC) beam (Table 4-3 and Fig. 4-16). The results supported the previous studies (Spainhour \& Wootton, 2008). When current passes through concrete, the minerals are suspended in a salt solution, and a certain amount of energy is needed to initiate corrosion in steel bars embedded in concrete. This is attributed to the fact that some of the passing currents do not contribute to corrosion, but are expanded while passing through the concrete cover. Natural corrosion was not counted while the sample was detached from the route for 2-3 day for maintenance and testing. In addition, some of the currents were passed through stirrups which were not considered for calculation. Assumed that steel bar was made of pure Iron when calculated theoretical mass loss based on Faraday's law. But, the chemical composition of steel commonly used $0.5 \%$ carbon. The integrity of concrete also plays an 
important role in the magnitude of the actual corrosion. These facts made the difference between actual and theoretical mass loss values and induced error in prediction.

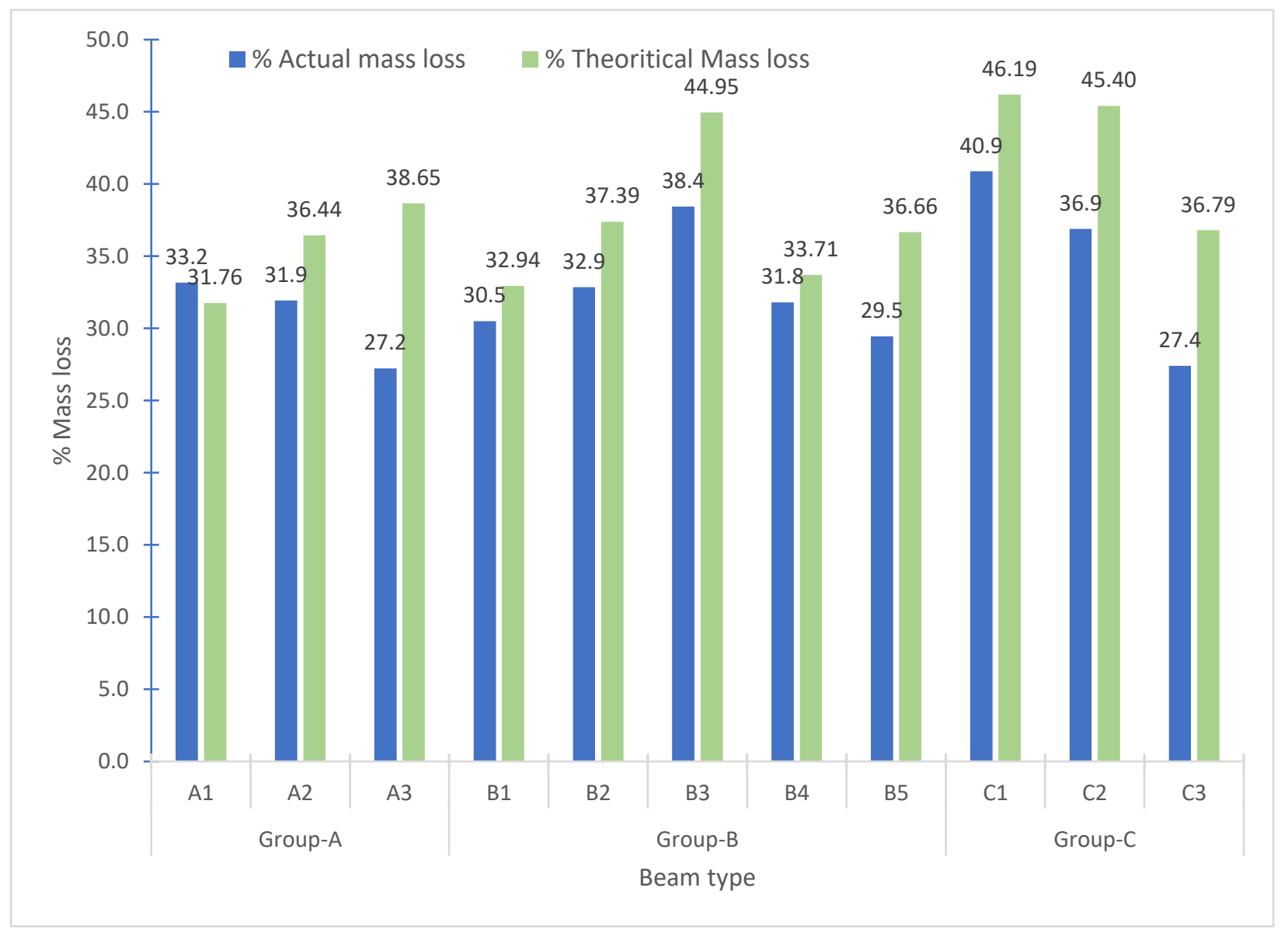

Figure 4-15: Comparison of actual and theoretical (Faraday's Law) mass loss

Figure 4-16 shows the percent error in-between the actual and predicted mass loss. The results show that concrete, that is sound with good corrosion resistance capacity has undergone the less corrosion than predicted. Figure 4-16 shows that Beam A3, B3, and C3 have higher negative percent errors. A negative value means that theoretical mass loss is greater than the actual mass loss. This implies that some of the currents did not contribute to corrosion and might have been consumed while passing through the concrete. On the contrary, it is rational that concrete that is deteriorated from corrosion damage will have cracks and decreased resistance, resulting in corrosion that is closer to predicted levels. The positive error (theoretical mass loss is lower than 
the actual mass loss) could be due to the unaccounted natural corrosion while these samples were awaited for destructive testing (Spainhour \& Wootton, 2008).

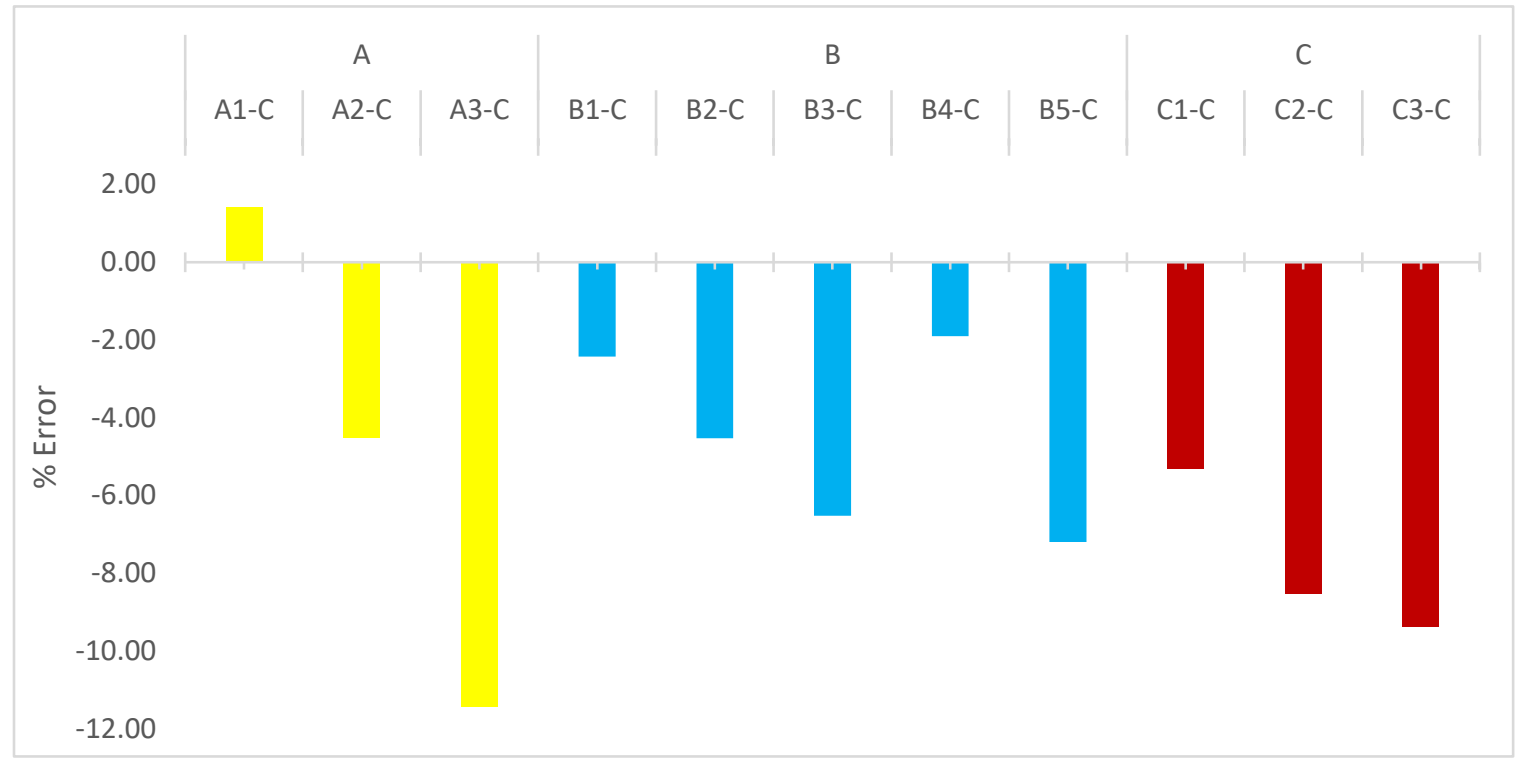

Figure 4-16: Percentage error of actual and theoretical bar mass loss

\subsection{Structural behavior of uncorroded and corroded beams}

In order to evaluate the performance of uncorroded beams and corroded beams before and after the corrosion, flexure tests were performed for 22 beams (11 corroded and 11 uncorroded) under simply supported condition by applying four point loading to failure. Load and deflection were captured through computerized data acquisition system while cracks and failure pattern were observed by physical inspection and pictures for the record. Shear span to effective depth ratio (a/d) was kept constant as 1.53 as well as adequate flexural reinforcement was provided with the reinforcement ratio of $1.14 \%$ for all beams.

\subsubsection{Load vs deflection behavior and failure mode of uncorroded beams}

The load and mid-span deflection were recorded from load cell and linear voltage displacement transducer (LVDT) through computerized data acquisition system during loading history. Table 4-4 summarizes experimental results indicating failure modes, load at first flexure crack $\left(\mathrm{P}_{\mathrm{fl}}\right)$, load at first diagonal crack $\left(\mathrm{P}_{\mathrm{c}}\right)$, deflection at first diagonal crack $\left(\mathrm{D}_{\mathrm{c}}\right)$, peak or failure load $\left(\mathrm{P}_{\mathrm{u}}\right)$, peak load deflection $\left(\mathrm{D}_{\mathrm{u}}\right)$ and angle of diagonal crack. The slope of initial straight line segment of the curve prior to flexural cracking is considered as stiffness of the beam. 


\subsubsection{Load vs deflection behavior and failure mode of uncorroded beams of group A}

Figure 4-17 shows the load vs deflection responses for the beams of group A. The full depth ECC/A3-F showed higher stiffness than beam SCC/A1-F and LWSCC/A2-F. The ultimate load capacity of beam A3-F was about $20 \%$ and $36 \%$ higher than the beams A1-F and A2-F. The mid span deflection at failure load ranged between 5.25 and $12.3 \mathrm{~mm}$ and ultimate failure load ranged from $116 \mathrm{kN}$ to $158.6 \mathrm{kN}$ for the group A beams. All beams showed shear mode of failure. The angle of dominant diagonal crack was approximately within the range of 35-45 degree.

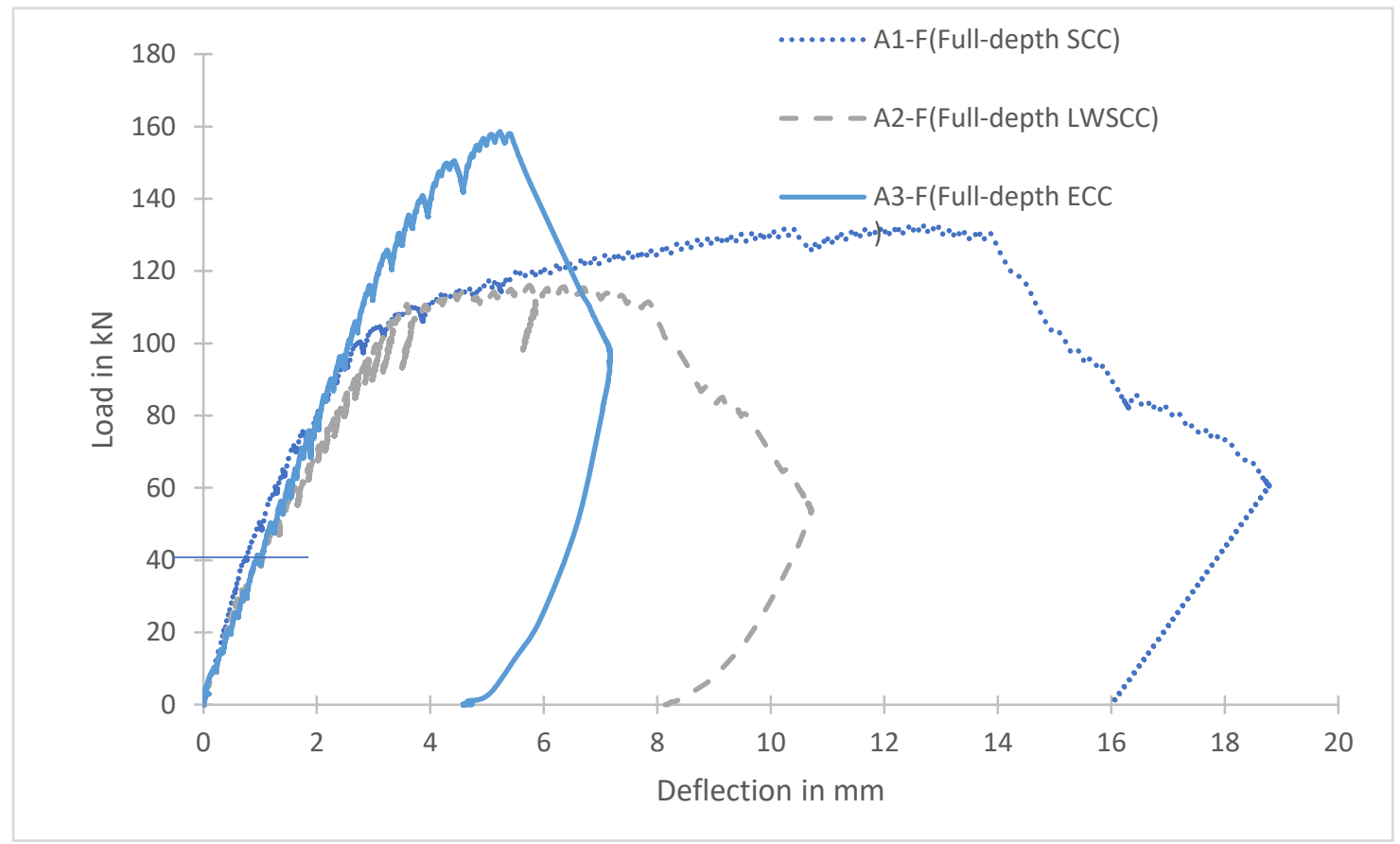

Figure 4-17: Load vs deflection curves of uncorroded beams of group A 
Table 4-4: Summary of strength, deflection and failure mode uncorroded beams

\begin{tabular}{|c|c|c|c|c|c|c|c|c|c|}
\hline $\begin{array}{l}\text { Beam } \\
\text { Group }\end{array}$ & $\begin{array}{c}\text { Beam } \\
\text { No. }\end{array}$ & Beam Name & $\begin{array}{l}\text { Failure } \\
\text { pattern }\end{array}$ & $\begin{array}{c}\mathrm{P}_{\mathrm{fl}} \\
(\mathrm{kN})\end{array}$ & $\begin{array}{c}\mathrm{D}_{\mathrm{c}} \\
(\mathrm{mm})\end{array}$ & $\begin{array}{c}\mathrm{P}_{\mathrm{c}} \\
(\mathrm{kN})\end{array}$ & $\begin{array}{c}\mathrm{P}_{\mathrm{u}} \\
(\mathrm{kN})\end{array}$ & $\begin{array}{c}\mathrm{D}_{\mathrm{u}} \\
(\mathrm{mm})\end{array}$ & $\begin{array}{c}\text { Diagonal } \\
\text { crack angle } \\
\text { (Degree) }\end{array}$ \\
\hline \multirow{3}{*}{$D$} & A1-F & Full-depth SCC & Shear & 40 & 1.25 & 60 & 132.56 & 12.30 & 35 \\
\hline & A2-F & Full-depth LWSCC & Shear & 30 & 0.95 & 40 & 116.02 & 5.75 & 42 \\
\hline & A3-F & Full-depth ECC & Shear & 50 & 2.01 & 80 & 158.60 & 5.24 & 35 \\
\hline \multirow{5}{*}{$\varpi$} & B1-F & $\mathrm{ECC} 100+\mathrm{SCC} 125$ & Shear & 50 & 2.02 & 90 & 164.21 & 10.32 & 50 \\
\hline & B2-F & ECC100+LWSCC125 & Shear & 40 & 1.32 & 60 & 150.42 & 8.07 & 40 \\
\hline & B3-F & $\begin{array}{l}\text { LWSCC+ECC } \\
\text { wrapping }\end{array}$ & Flexure & 50 & 2.10 & 60 & 137.15 & 20.81 & 70 \\
\hline & B4-F & ECC50+SCC150 & Shear & 40 & 1.29 & 60 & 131.50 & 3.59 & 45 \\
\hline & B5-F & ECC50+LWSCC150 & Shear & 40 & 1.37 & 60 & 138.34 & 6.76 & 30 \\
\hline \multirow{3}{*}{2} & $\mathrm{C} 1-\mathrm{F}$ & LWSCC $+.25 \%$ PVA & Shear & 30 & 1.69 & 50 & 102.46 & 4.02 & 35 \\
\hline & $\mathrm{C} 2-\mathrm{F}$ & LWSCC + $1 \%$ CR & Shear & 20 & 0.69 & 30 & 95.04 & 3.34 & 38 \\
\hline & $\mathrm{C} 3-\mathrm{F}$ & LWSCC + 1\% HDPE & Shear & 40 & 1.24 & 50 & 97.27 & 3.68 & 35 \\
\hline
\end{tabular}

- $\quad$ load at first flexure crack $\left(\mathrm{P}_{\mathrm{fl}}\right)$, load at first diagonal crack $\left(\mathrm{P}_{\mathrm{c}}\right)$, deflection at first diagonal crack $\left(\mathrm{D}_{\mathrm{c}}\right)$, peak or failure load $\left(\mathrm{P}_{\mathrm{u}}\right)$, peak load deflection $\left(\mathrm{D}_{\mathrm{u}}\right)$ and angle of diagonal crack

\subsubsection{Load vs deflection behavior and failure mode of uncorroded composite beams of group B}

Figure 4-18 shows the load vs deflection responses for the beams of group B. Table 4-4 summarizes the key parameters derived from the test results. All composite beams were failed by shear except the beam LWSCC+ECC wrapping/B3-F. The beam B3-F failed directly under loading point (as shown Appendix A). All composite beams exhibited initial constant slope in load-deflection responses till 40kN. Beams B1-F (ECC100+125SCC) and B3-F (LWSCC+ECC wrapping) showed higher initial stiffness (first flexure cracking load) than the other beams in the group. The mid span deflection at failure load ranged from 3.59 to $10.32 \mathrm{~mm}$ and ultimate failure load ranged from $131.5 \mathrm{KN}$ to $164.41 \mathrm{kN}$ for the group B beams. The beam B1-F showed the highest ultimate load capacity $(164.41 \mathrm{kN})$ while beam B4-F the lowest $(131.50 \mathrm{kN})$. The angle of dominant diagonal crack was approximately within the range of 30-70 degree.

The composite beams B1-F(ECC100+SCC125) and B2-F(ECC100+LWSCC125) exhibited better performance (higher ultimate load and higher deflection) than composite beams B4-F (ECC50+SCC150) and B5-F(ECC50+LWSCC150) possibly due to higher total depth, higher 
thickness of ECC layer and cover thickness. Beams B1-F and B2-F had $45 \mathrm{~mm}$ cover and beams B4-F and B5-F had $20 \mathrm{~mm}$ cover.

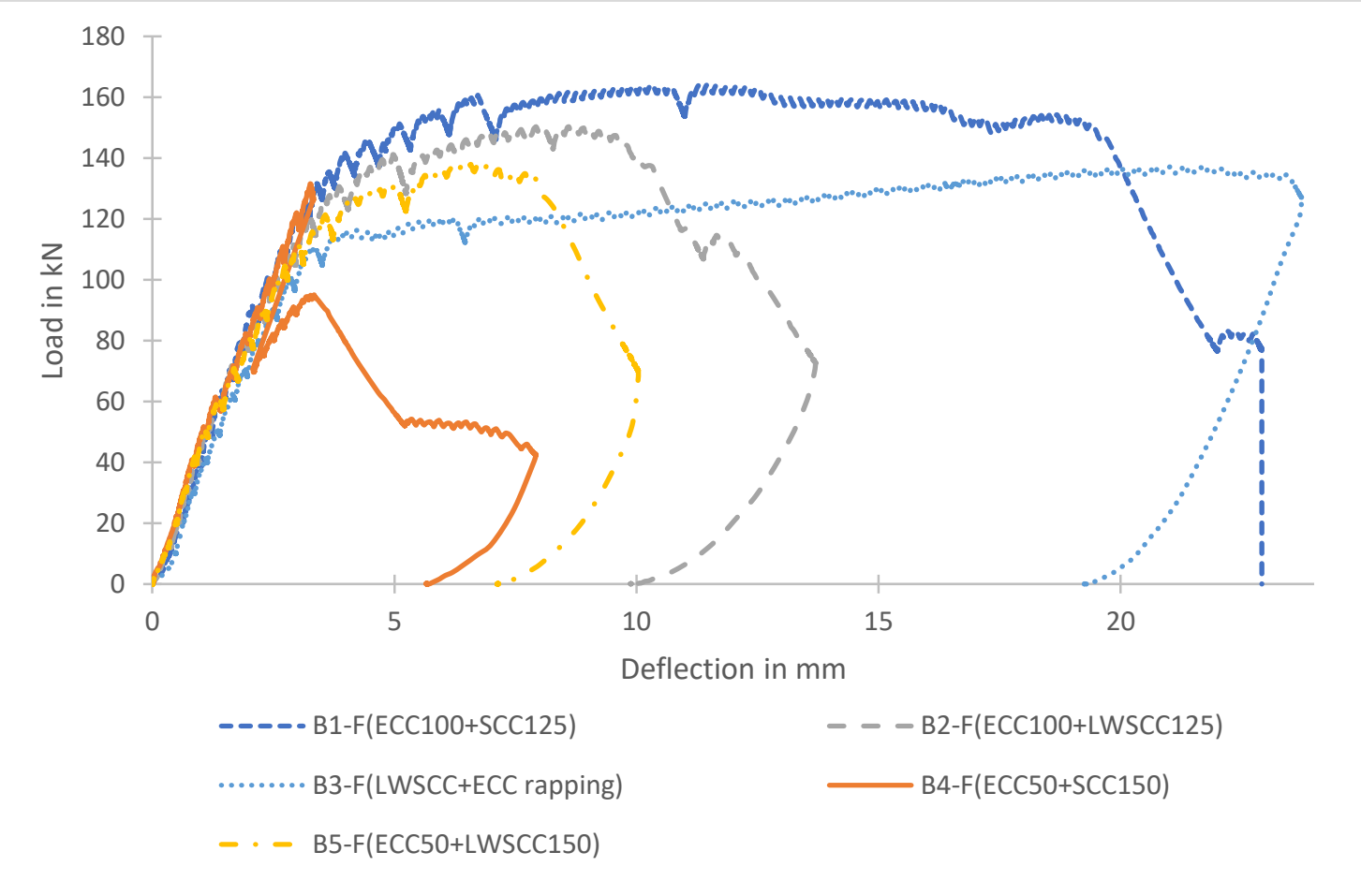

Figure 4-18: Load vs deflection curve of uncorroded beams of group B

\subsubsection{Load vs deflection behavior and failure mode of uncorroded beams of group C}

Figure 4-19 shows the load vs deflection responses for the beams of group C and Table 4-4 shows the summary of experimental results. All FRLWSCC beams failed by shear. The mid span deflection at failure load ranged from 3.34 to $4.02 \mathrm{~mm}$ and ultimate failure load or shear load ranged from $95.04 \mathrm{kN}$ to $102.46 \mathrm{kN}$ for the group C beams. All FRLWSCC beams exhibited constant slope until $40 \mathrm{kN}$ load. Beams C3-F(LWSCC+HDPE) showed higher stiffness with beam C2-F (LWSCC+ CR) being the lowest. The beam C1-F (LWSCC+PVA) showed higher ultimate load capacity $(102.46 \mathrm{kN})$ with beam C2-F (LWSCC+CR) showing the lowest $(95.04 \mathrm{kN})$. The mid span deflection at failure load ranged from 3.34 to $4.02 \mathrm{~mm}$ and ultimate failure load or shear load ranged from $95.04 \mathrm{kN}$ to $102.46 \mathrm{kN}$ for the group $\mathrm{C}$ beams. The angle of dominant diagonal crack was approximately within the range of 35-78 degree. 


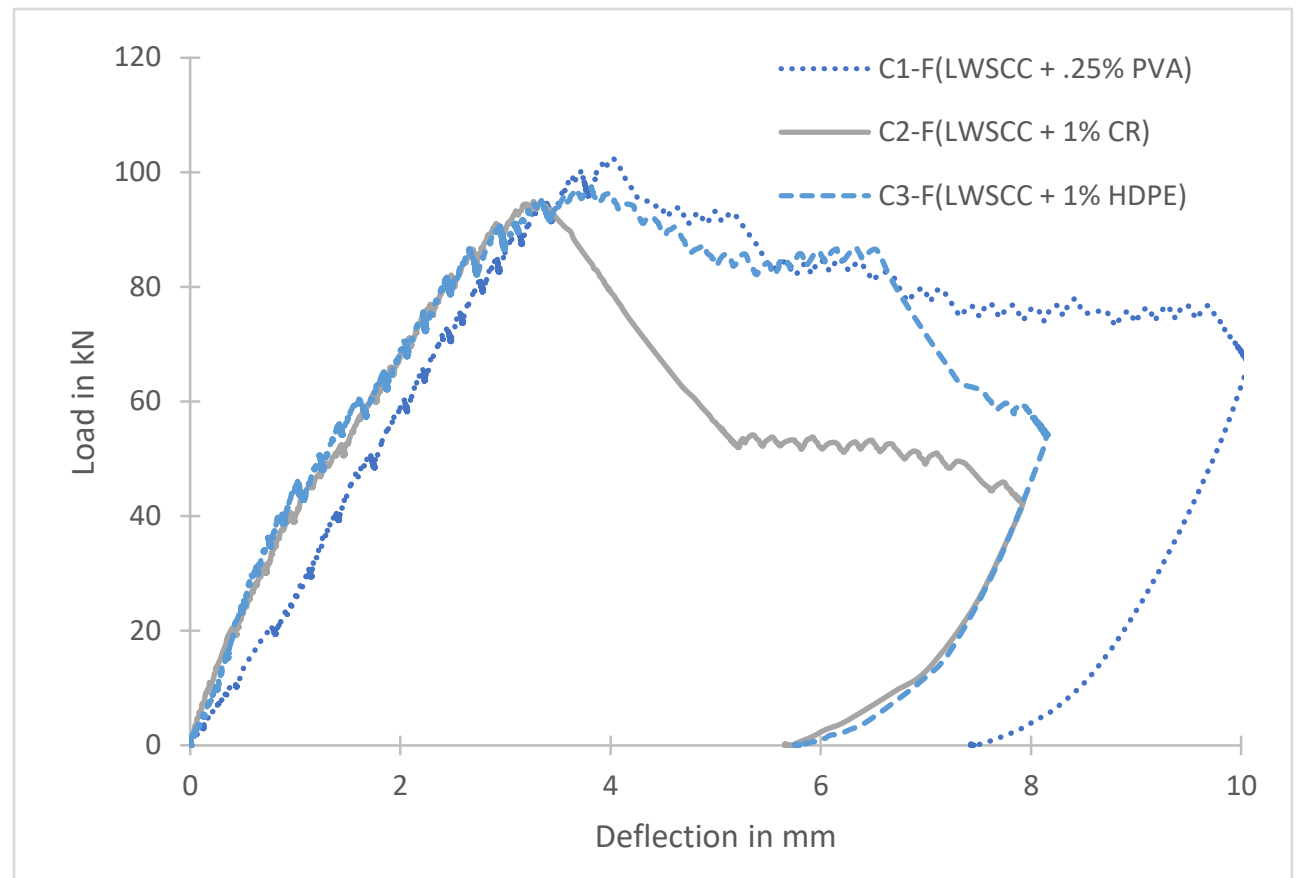

Figure 4-19: Load vs deflection curve of uncorroded beams of group C

\subsubsection{Overall load vs deflection behavior and failure mode of uncorroded beams}

Table 4-4 and Appendix A show the failure modes and crack pattern of all uncorroded beams. All uncorroded beams exhibited shear failure mode except beam B3-F (LWSCC+ECC wrapping). Beams A3-F (full depth ECC), B1-F (ECC100+SCC125) and B3-F (LWSCC+ECC rapping) showed higher stiffness than rest of the beams. Full depth SCC/A1-F and composite beams B4F(ECC50+SCC150) exhibited similar stiffness and ultimate loading capacity. Full depth LWSCC/A2-F beam and composite beam B5-F (ECC50+LWSCC150) exhibited similar stiffness but beam B5-F had shown higher loading capacity. Beam B2-F (Full depth LWSCC) and composite beam B3-F (LWSCC+ 14mm ECC wrapping) had similar dimension. However, beam B3-F exhibited superior performance $\left(\mathrm{P}_{\mathrm{u}}: 137.5 \mathrm{kN}\right.$, Dc: $20.81 \mathrm{~mm}$ and $\left.\mathrm{P}_{\mathrm{fl}}: 50 \mathrm{kN}\right)$ than beam LWSCC/A2-F ( $\mathrm{P}_{\mathrm{u}}: 116.02 \mathrm{kN}$, Dc: $5.75 \mathrm{~mm}$ and $\left.\mathrm{P}_{\mathrm{fl}}: 30 \mathrm{kN}\right)$ showing higher strength and ductility due to the presence of $14 \mathrm{~mm}$ ECC wrapping increase of the beam.

Full depth LWSCC/A2-F beam shown the superior performance than the fiber reinforced LWSCC beams (C1-F, C2-F and C3-F). Introducing fiber in LWSCC lead to decrease in stiffness and decrease ultimate load capacity of FRLWSCC beams compared to LWSCC beam counterpart. 
In general, use of ECC layer or ECC wrapping increased the ultimate capacity of composite beams compared to their full depth counterparts (Table 4-4).

\subsubsection{Post-cracking shear resistance, ductility and energy absorption capacity of uncorroded beam}

Aggregate interlock mechanism and dowel action play significant roles in the increase of shear resistance from $\mathrm{P}_{\mathrm{c}}$ (shear resistance load at the formation of inclined crack) to $\mathrm{P}_{\mathrm{u}}$ (ultimate shear resistance or peak load). The ultimate shear resistance $\left(\mathrm{P}_{\mathrm{u}}\right)$ was documented from the ultimate load (peak load) that a beam can carry before failure- A similar examination was carried out by previous researchers, Lachemi et al. (2005) and Hassan et al. (2010), by introducing a shear resistance factor $(\mathrm{SRF}) . \mathrm{SRF}$ is defined as the ratio of the failure load $\left(\mathrm{P}_{\mathrm{u}}\right)$ to the load/ shear at the first transverse cracks $\left(\mathrm{P}_{\mathrm{c}}\right)$ as per Equation 4.1.

$\mathrm{SRF}=\mathrm{P}_{\mathrm{u}} / \mathrm{P}_{\mathrm{c}}$

The post cracking shear ductility was defined as the ratio of the deflection at failure load $\left(\mathrm{D}_{\mathrm{u}}\right)$ to the deflection at first oblique crack load $\left(D_{c}\right)$ by previous scientist Hassan et al. (2010). In this study, the ductility of the shear beam is also well-defined by the ductility factor (DF) as per Equation 4.2:

$\mathrm{DF}=\mathrm{D}_{\mathrm{u}} / \mathrm{D}_{\mathrm{c}}$

The first flexural cracking load was observed visually and confirmed by marking the first crack. It was an indication of slope change of load-deflection curve. Correspondingly, the first diagonal cracking load was observed visually and marked properly by taking picture. The deflection was recorded from LVDT reading mounted at the center of the beam. Table 4-5 shows the summary of the beams SRF, DF, EAC (Energy abruption capacity) and moment capacity.

The SRF was lower in beams A3-F, B3-F and C3-F in respective groups (Table 4-5). The lower ratio SRF in beams A3-F, B3-F, and C3-F supports the development of lower post cracking shear resistance. The values of DF $\left(\mathrm{D}_{\mathrm{u}} / \mathrm{D}_{\mathrm{c}}\right)$ were lower in beams $\mathrm{A} 3-\mathrm{F}, \mathrm{B} 4-\mathrm{F}$, and $\mathrm{C} 1-\mathrm{F}$, respectively, compared each group (Table 4-5).

Energy absorption capacity was calculated by area under the load-deflection curves (Figure 4-27 to 4-37) up to the post peak load of $85 \%$ of the ultimate failure load $\left(\mathrm{P}_{\mathrm{u}}\right)$ and presented in Table 45. Full depth SCC/A1-F (1576.25 Joules), composite beam ECC100+LWSCC125/ B1-F (2802.5 joules) and LWSCC+1\%CRC/C2-F (595 joules) exhibited the highest energy absorption capacity 
in the respective group. Figure 4-20 shows the graphical comparison of shear resistance factor (SRF) and ductility factor (DF) with Figure 4-21 showing the energy absorption capacity of the uncorroded beams.

The use ECC layer increased the energy absorbing capacity of composite beams (in Group B) compared to their full depth counterparts with ECC wrapping being the more effective (Table 4$5)$.

Table 4-5:Summary of beam, SRF, DF, EAC and moment capacity uncorroded beams

\begin{tabular}{|c|c|c|c|c|c|c|c|}
\hline $\begin{array}{l}\text { Beam } \\
\text { Group }\end{array}$ & $\begin{array}{c}\text { Beam } \\
\text { No. }\end{array}$ & Beam Name & $\begin{array}{l}\mathrm{SRF} \\
\left(\mathrm{P}_{\mathrm{P}} / \mathrm{P}_{\mathrm{c}}\right)\end{array}$ & $\begin{array}{c}\mathrm{DF} \\
\left(\mathrm{D}_{\mathrm{u}} / \mathrm{D}_{\mathrm{c}}\right)\end{array}$ & $\begin{array}{c}\text { Diagonal } \\
\text { crack } \\
\text { angle } \\
\text { (Degree) }\end{array}$ & $\begin{array}{l}\text { EAC, } \\
85 \% \text { of } \\
\text { ultimate } \\
\text { load, (J) }\end{array}$ & $\begin{array}{l}\text { Moment } \\
\text { capacity } \\
(\mathrm{kN}-\mathrm{m})\end{array}$ \\
\hline \multirow{3}{*}{$>$} & A1-F & Full-depth SCC & 2.21 & 9.82 & 35 & 1574.25 & 17.70 \\
\hline & A2-F & Full-depth LWSCC & 2.90 & 6.03 & 42 & 798.00 & 15.49 \\
\hline & A3-F & Full-depth ECC & 1.98 & 2.61 & 35 & 595.35 & 21.17 \\
\hline \multirow{5}{*}{$\varpi$} & B1-F & ECC100+SCC125 & 1.82 & 5.10 & 50 & 2802.50 & 21.92 \\
\hline & B2-F & ECC100+LWSCC125 & 2.51 & 6.13 & 40 & 1157.87 & 20.08 \\
\hline & B3-F & $\begin{array}{l}\text { LWSCC+ECC } \\
\text { wrapping }\end{array}$ & 2.29 & 9.91 & 70 & 2721.50 & 18.31 \\
\hline & B4-F & ECC $50+S C C 150$ & 2.19 & 2.78 & 45 & 310.55 & 17.56 \\
\hline & B5-F & ECC50+LWSCC150 & 2.31 & 4.93 & 30 & 938.50 & 18.47 \\
\hline \multirow{3}{*}{$\Omega$} & C1-F & LWSCC $+.25 \%$ PVA & 2.05 & 2.37 & 35 & 377.38 & 13.68 \\
\hline & $\mathrm{C} 2-\mathrm{F}$ & $\mathrm{LWSCC}+1 \% \mathrm{CR}$ & 3.17 & 4.85 & 38 & 595.00 & 12.69 \\
\hline & C3-F & LWSCC + 1\% HDPE & 1.95 & 2.96 & 35 & 487.40 & 12.99 \\
\hline
\end{tabular}

The use ECC layer increased the energy absorbing capacity of composite beams (in Group B) compared to their full depth counterparts with ECC wrapping being the more effective. 


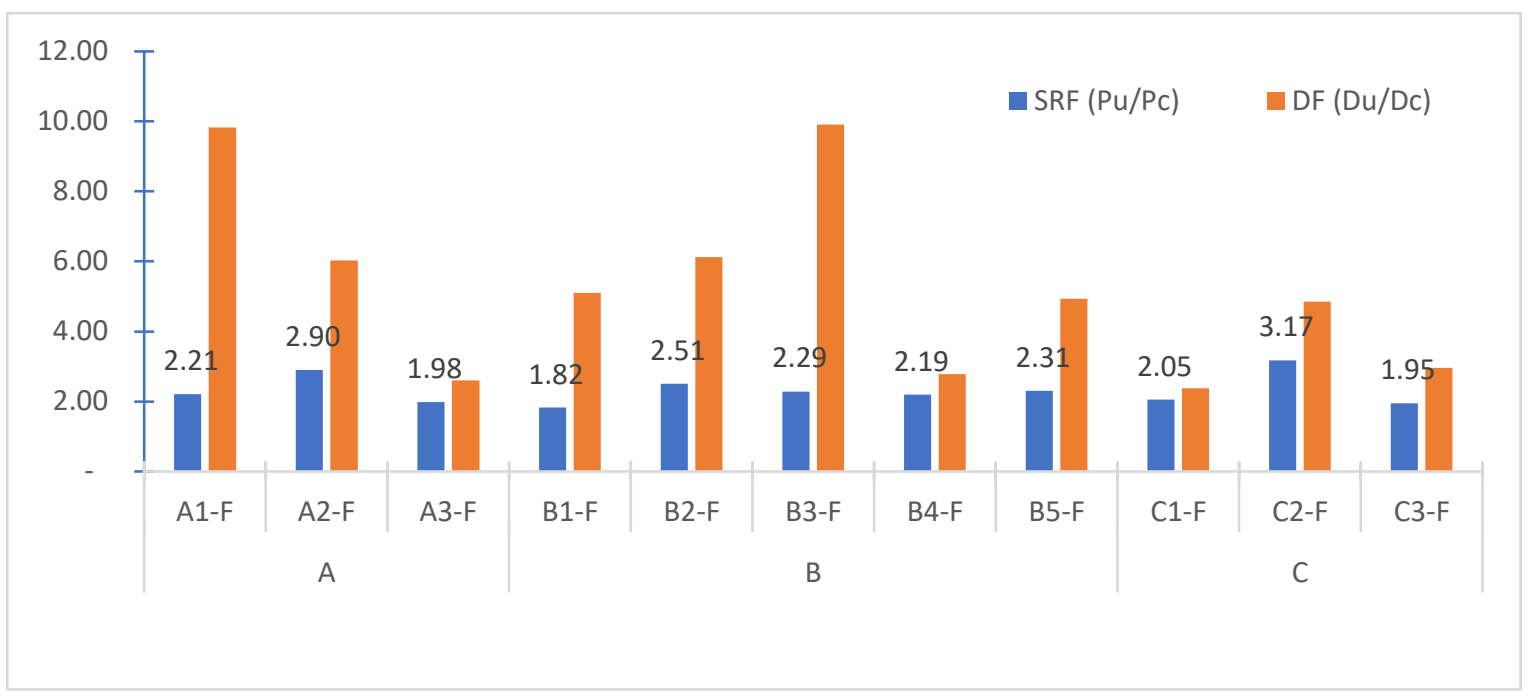

Figure 4-20: Comparisons of SRF and DF of uncorroded beams

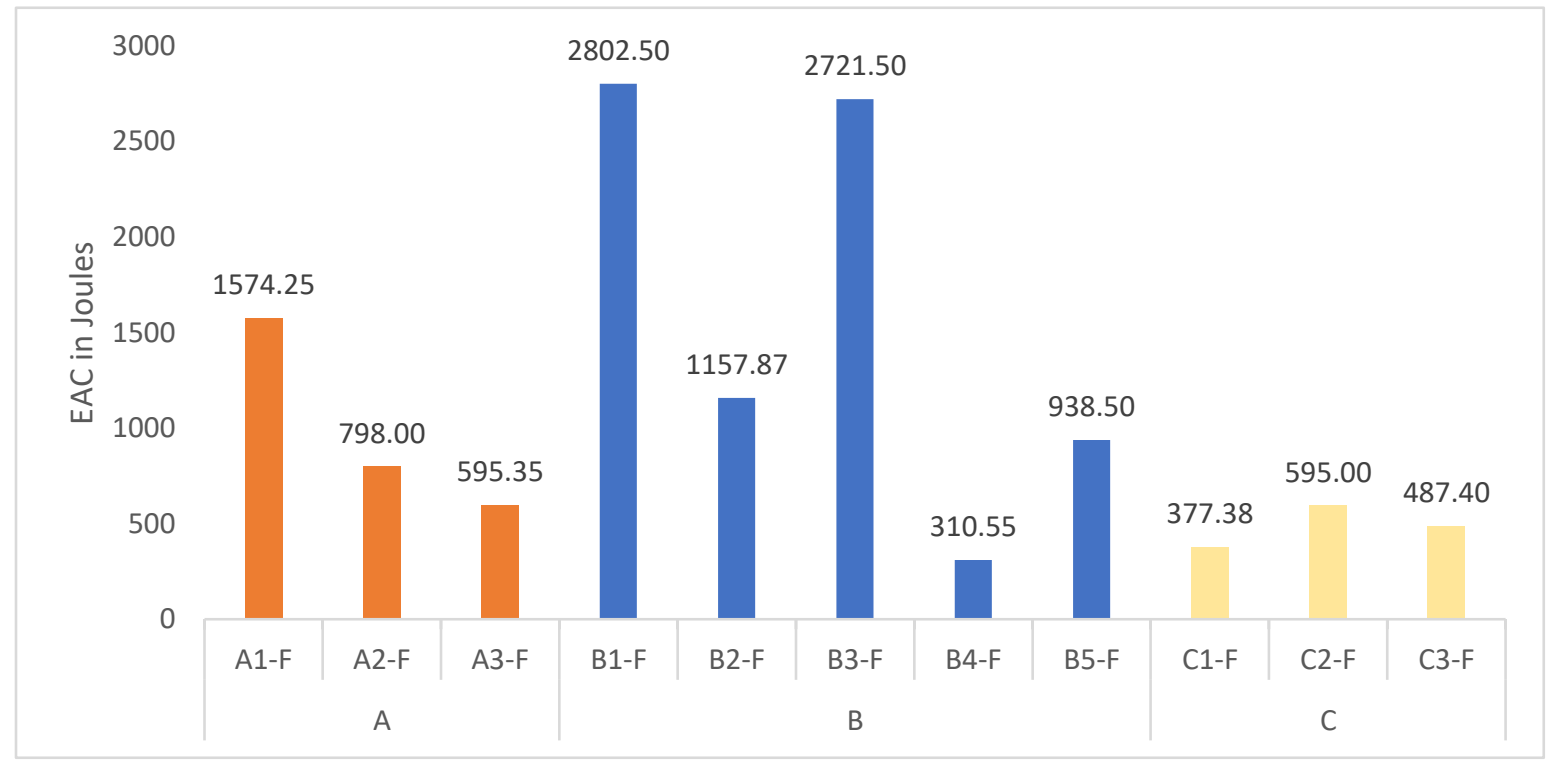

Figure 4-21: EAC of uncorroded beams

\subsubsection{Load vs deflection behavior and failure mode of corroded beams}

\subsubsection{Load vs deflection behavior and failure mode of corroded beams of group A}

Figure 4-22 shows the load vs deflection responses of the corroded beams of group A and Table 4-6 shows the summary of experimental results. The beam A3-C (full depth ECC) showed higher stiffness than beams A1-C (full depth SCC) and A2-C (full depth LWSCC). The ultimate load 
capacity for beam ECC/A3-C was about 50\% and 40\% higher, respectively than the SCC/A1-C and LWSCC/A2-C. The mid span deflection at failure load ranged from 3.52 to $12.43 \mathrm{~mm}$ and ultimate failure load ranged from $93.5 \mathrm{kN}$ to $140.0 \mathrm{kN}$ for the group A beams. Beams SCC/A1-C failed by shear, LWSCC/A2-C in shear while ECC/A3-C showed flexure mode of failure with fewer cracks. The angle of dominant diagonal crack was approximately within the range of 30-85 degree with ECC showing 85 degree. Full depth ECC beams showed better corrosion resistance than their SCC or LWSCC counterparts by retaining higher (40 to 50\% higher) post-corroded strength than their SCC or LWSCC counterparts with failure mode also changing from shear to flexure -

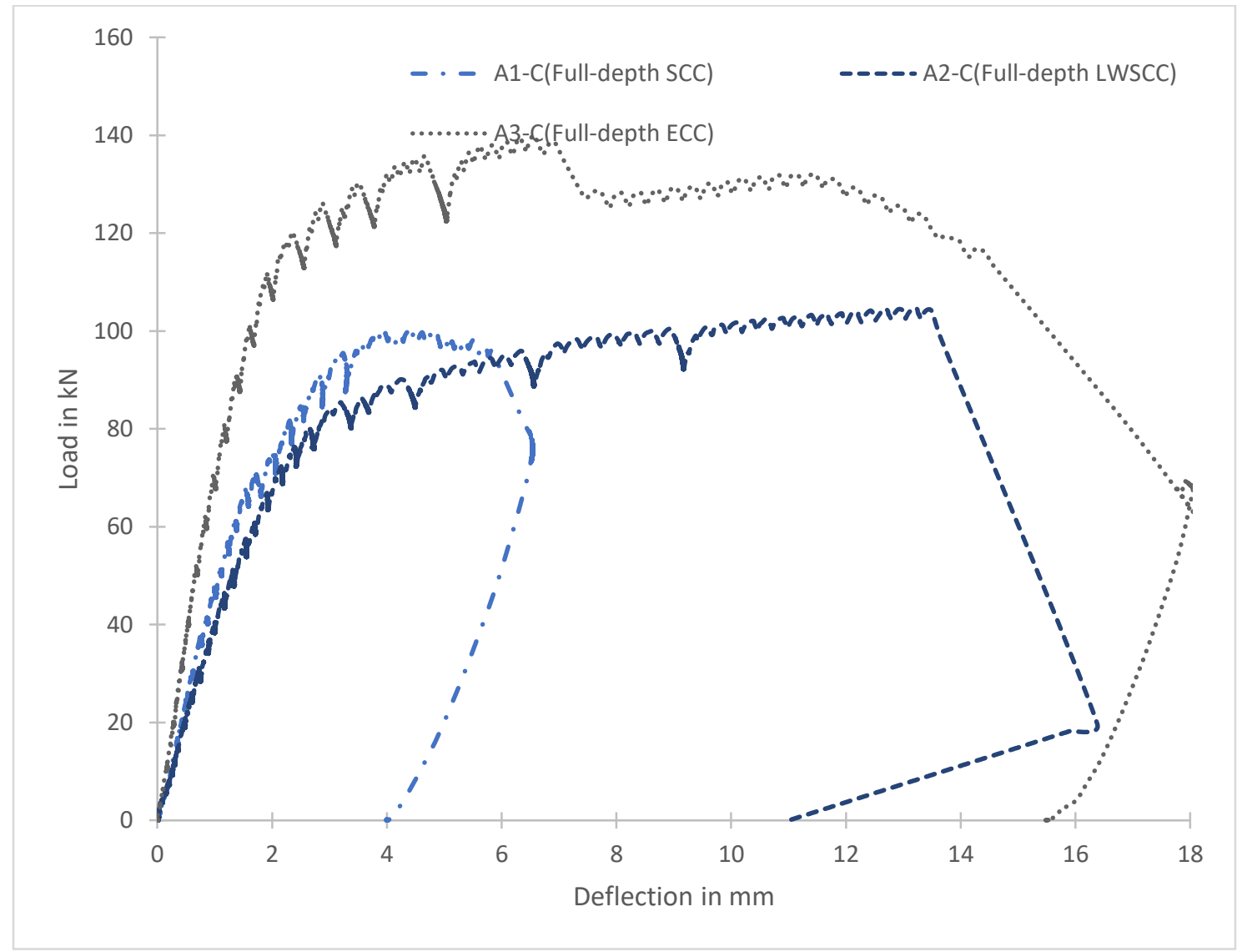

Figure 4-22: Load vs deflection curve of corroded beams group A 


\subsubsection{Load vs deflection behavior and failure mode of corroded beams of group B}

Figure 4-23 shows the load-deflection responses for the corroded beams of group B and Table 46 summarizes the results. The beam B3-C (LWSCC+ECC wrapping) and B4C(ECC50+LWSCC150) had shown the higher stiffness than rest of the beams in group B. The ultimate load capacity for beams B1-C to B4-C was very close (B1-C:1142 kN, B2-C:114.5 kN, B3-C:115.1kN, B4-C:119.4kN) and B5-C was $97.2 \mathrm{kN}$. The mid span deflection at failure load ranged from 3.25 to $7.83 \mathrm{~mm}$. Beams B1-C failed by flexure (under the loading point). And, rest of the beams exhibited shear mode of failure with fewer cracks (Appendix A). The angle of dominant diagonal crack was approximately within the range of 35-90 degree.

The composite beams B1-C(ECC100+SCC125) and B2-C(ECC100+LWSCC125) had shown the superior performance (higher ultimate load and higher deflection) than composite beams B4$\mathrm{C}(\mathrm{ECC} 100+\mathrm{SCC} 125)$ and $\mathrm{B} 5-\mathrm{C}(\mathrm{ECC} 100+\mathrm{LWSCC} 150)$ due to higher depth and increased cover thickness.

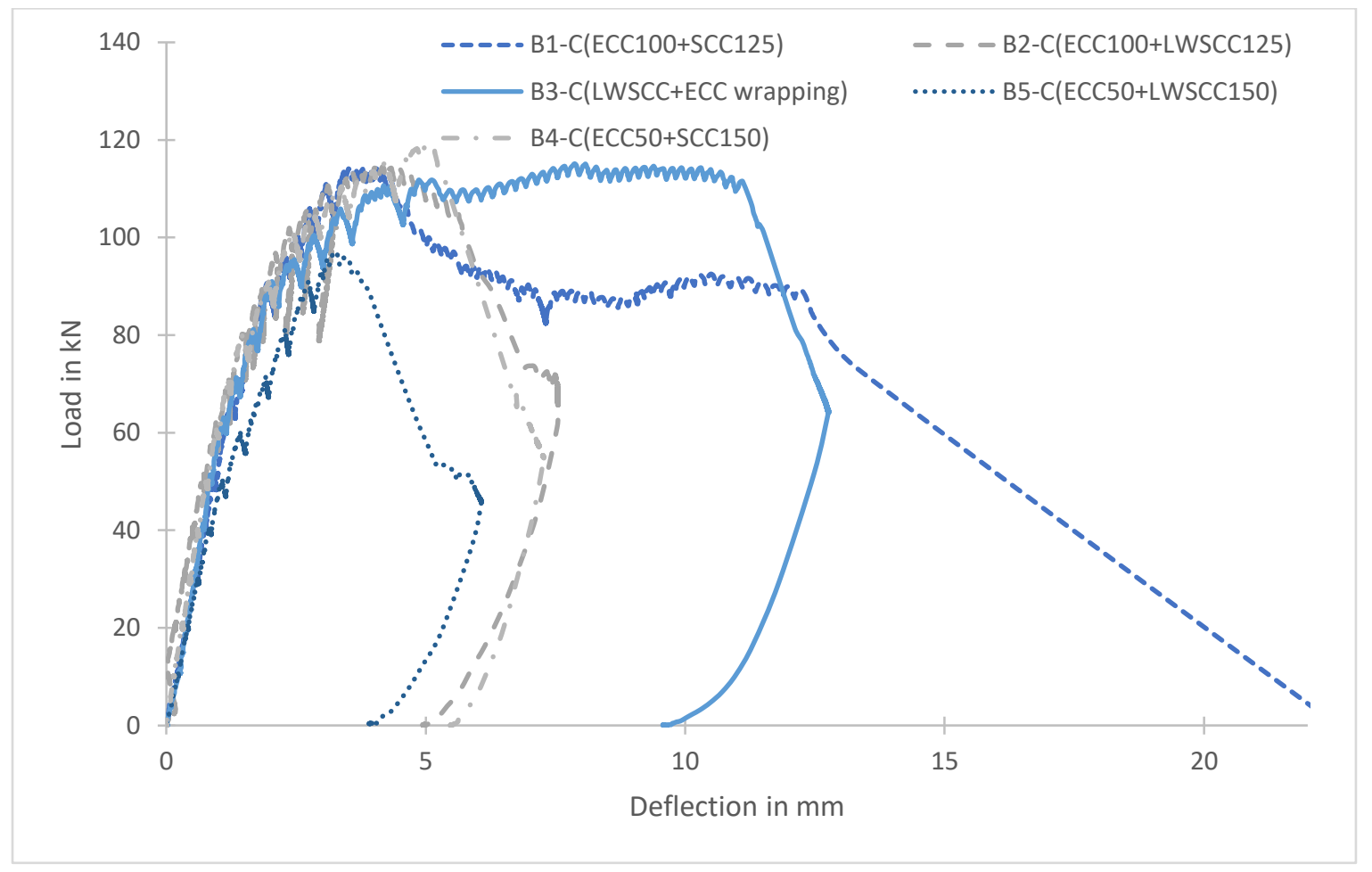

Figure 4-23: Load vs deflection curve of corroded beams of group B 


\subsubsection{Load vs deflection behavior and failure mode of corroded beams of group C}

Figure 4-24 shows the load-deflection responses for the corroded beams of group $\mathrm{C}$ and Table 46 summarizes the results. The beam C3-C (LWSCC+1\%HDPE) showed higher stiffness than the beams C1-C (LWSCC+0.25\%PVA) and C2-C (LWSCC+CR) in group C. The ultimate load capacity for beams $\mathrm{C} 1-\mathrm{C}, \mathrm{C} 2-\mathrm{C}$ and $\mathrm{C} 3-\mathrm{C}$ were $63.8 \mathrm{kN}, 56.2 \mathrm{kN}$ and $79.0 \mathrm{kN}$ respectively. The mid span deflection at failure load ranged from 4.59 to $13.81 \mathrm{~mm}$ and ultimate failure load or shear load ranged from $56.2 \mathrm{kN}$ to $97.0 \mathrm{kN}$ for the group $\mathrm{C}$ beams. The beams $\mathrm{C} 1-\mathrm{C}$ and $\mathrm{C} 2-\mathrm{C}$ failed by flexure with spalling (Appendix A) and beams C3-C exhibited shear mode of failure with fewer cracks and small spalling at the bottom end (Appendix A). The angle of dominant diagonal crack was approximately within the range of 30-90 degree.

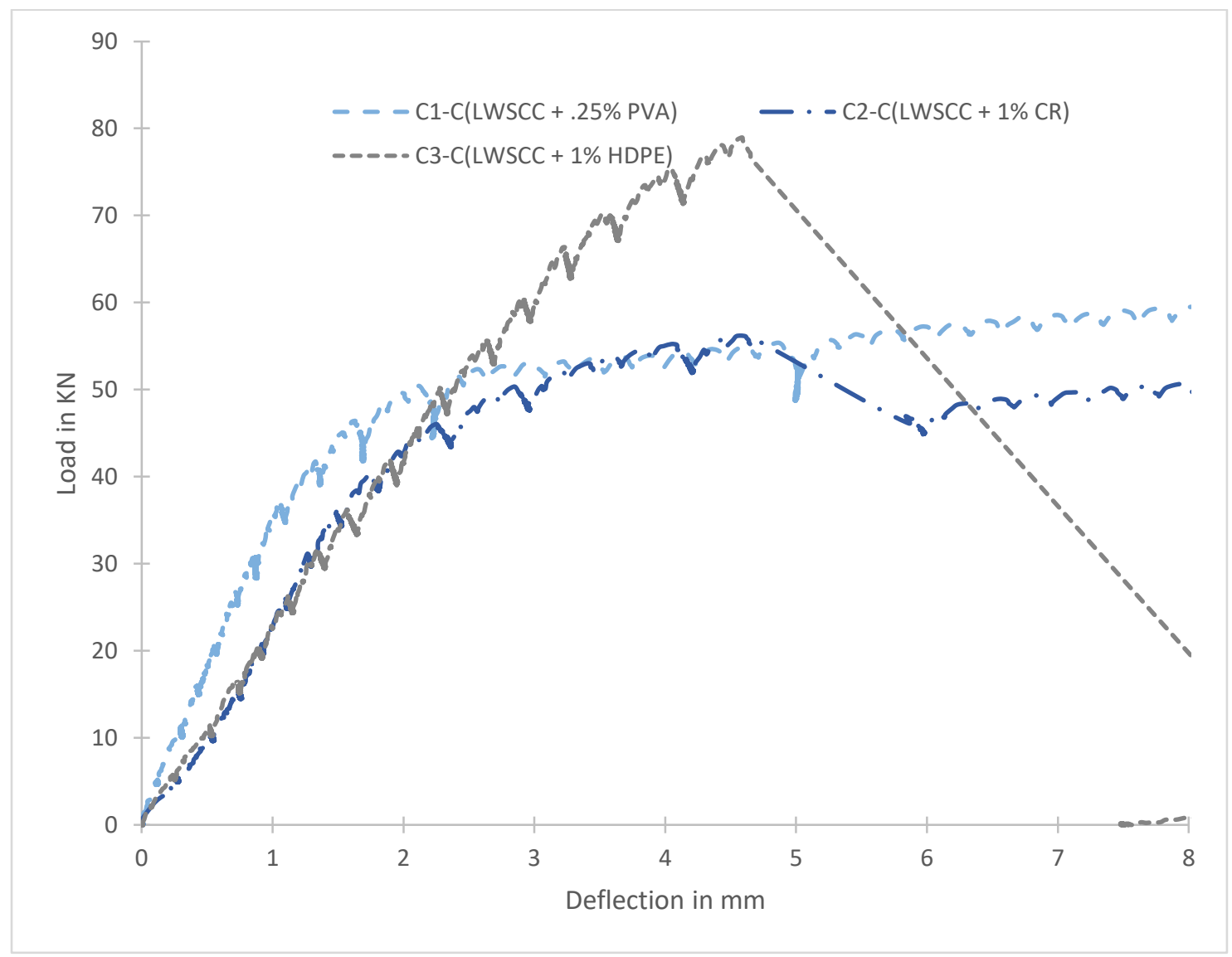

Figure 4-24: Load vs deflection curve of corroded beam of group C 
Table 4-6:Summary of beam strength, deflection, failure mode of corroded beams

\begin{tabular}{|c|c|c|c|c|c|c|c|c|c|}
\hline $\begin{array}{l}\text { Beam } \\
\text { Group }\end{array}$ & $\begin{array}{c}\text { Beam } \\
\text { No. }\end{array}$ & Beam Type & $\begin{array}{l}\text { Failure } \\
\text { pattern }\end{array}$ & $\begin{array}{c}P_{f l} \\
(k N)\end{array}$ & $\begin{array}{c}D_{c} \\
(\mathrm{~mm})\end{array}$ & $\begin{array}{c}\mathrm{P}_{\mathrm{c}} \\
(\mathrm{kN})\end{array}$ & $\begin{array}{c}\mathrm{Pu}_{\mathrm{u}} \\
(\mathrm{kN})\end{array}$ & $\begin{array}{c}\mathrm{Du}_{\mathrm{u}} \\
(\mathrm{mm})\end{array}$ & $\begin{array}{c}\text { Diagonal } \\
\text { crack } \\
\text { angle } \\
\text { (Degree) }\end{array}$ \\
\hline \multirow{3}{*}{$D$} & A1-C & Full-depth SCC & Shear & 35 & 1.69 & 70 & 93.5 & 3.52 & 30 \\
\hline & $A 2-C$ & Full-depth LWSCC & Shear & 30 & 2.09 & 70 & 100.5 & 12.43 & 40 \\
\hline & A3-C & Full-depth ECC & flexure & 60 & 3.49 & 125 & 140.0 & 6.28 & 85 \\
\hline \multirow{5}{*}{$\infty$} & B1-C & ECC100+SCC125 & flexure & 50 & 2.29 & 95 & 114.2 & 3.51 & 90 \\
\hline & $\mathrm{B} 2-\mathrm{C}$ & ECC100+LWSCC125 & Shear & 60 & 1.68 & 85 & 114.5 & 3.74 & 40 \\
\hline & B3-C & $\begin{array}{l}\text { LWSCC+ECC } \\
\text { wrapping }\end{array}$ & Shear & 70 & 2.83 & 100 & 115.1 & 7.86 & 35 \\
\hline & B4-C & ECC $50+$ SCC 150 & Shear & 70 & 1.43 & 80 & 119.4 & 5.02 & 35 \\
\hline & $\mathrm{B} 5-\mathrm{C}$ & ECC50+LWSCC150 & Shear & 40 & 1.41 & 60 & 97.2 & 3.25 & 40 \\
\hline \multirow{3}{*}{$n$} & C1-C & LWSCC $+.25 \%$ PVA & Flexure & 45 & 2.08 & 50 & 63.8 & 13.81 & 90 \\
\hline & $\mathrm{C} 2-\mathrm{C}$ & LWSCC + $1 \%$ CR & Flexure & 35 & 2.81 & 50 & 56.2 & 4.58 & 30 \\
\hline & $\mathrm{C} 3-\mathrm{C}$ & LWSCC $+1 \%$ HDPE & Shear & 40 & 2.60 & 55 & 79.0 & 4.59 & 35 \\
\hline
\end{tabular}

load at first flexure crack $\left(\mathrm{P}_{\mathrm{fl}}\right)$, load at first diagonal crack $\left(\mathrm{P}_{\mathrm{c}}\right)$, deflection at first diagonal crack $\left(\mathrm{D}_{\mathrm{c}}\right)$, peak or failure load $\left(\mathrm{P}_{\mathrm{u}}\right)$, peak load deflection $\left(\mathrm{D}_{\mathrm{u}}\right)$ and angle of diagonal crack

\subsubsection{Overall load vs deflection behavior and failure mode of corroded beams}

Table 4-6 and Appendix A show the failure mode and crack pattern of all corroded beams. Seven corroded beams exhibited shear mode of failure and four beams exhibited shear mode of failure. The beams full depth ECC/A3-C, LWSCC+ECC wrapping/B3-C and LWSCC-HDPE/C3-C exhibited the highest diagonal cracking load from the respective group.

Beam A2-C (full depth LWSCC) and composite beam B3-C (LWSCC+ 14mm ECC wrapping) had similar dimension but B3-C exhibited superior performance $\left(\mathrm{P}_{\mathrm{u}}: 115.1 \mathrm{kN}\right.$ and $\left.\mathrm{P}_{\mathrm{fl}}: 70 \mathrm{kN}\right)$ after corrosion than beam A2-C $\left(\mathrm{P}_{\mathrm{u}}: 100.5 \mathrm{kN}\right.$ and $\left.\mathrm{P}_{\mathrm{f} 1}: 30 \mathrm{kN}\right)$ in terms of higher failure and $1^{\text {st }}$ flexure cracking load due to better corrosion resistance provided by $14 \mathrm{~mm}$ ECC wrapping Full depth LWSCC/A2-C beam showed superior performance compared to its FRLWSCC counterparts (C1-C, C2-C and C3-C). Introducing fiber in LWSCC concrete lead to decrease in corrosion resistance leading to lower stiffness and ultimate load capacity. 


\subsubsection{Post-cracking shear resistance, ductility and energy absorption capacity of corroded beams}

Table 4-7 shows the summary of SRF, DF, EAC and moment capacity of corroded beams. The ratio of the ultimate failure load to the first diagonal cracking load $\left(\mathrm{SRF}=\mathrm{P}_{\mathrm{u}} / \mathrm{P}_{\mathrm{c}}\right)$ was lower in beams ECC/A3-C (1.12), LWSCC+ECC wrapping/B3-C (1.15) and C2-C 1.12) in their respective groups (Table 4-7). The lower SRF in beams A3-C, B3-C, and C2-C supports the development of lower post-cracking shear resistance due to corrosion. The ductility $\left(\mathrm{DF}=\mathrm{D}_{\mathrm{u}} / \mathrm{D}_{\mathrm{c}}\right)$ were lower in beams A3-C (1.8), B2-C (1.53), and C2-C (1.63) amongst the beams of their group (Table 4-7).

Corroded beams full depth ECC/ A3-C (1665 Joules), composite of LWSCC+ECC wrapping/ B3-C (1143 joules) and LWSCC+0.25\%PVA (952 joules) exhibited higher exergy absorption capacity than all others beam. Figure 4-25 shows the graphical comparison of shear resistance factor (SRF), ductility factor (DF) and energy absorption capacity. Figure 4-26 shows the energy absorption capacity of uncorroded beams.

Table 4-7: Summary of beam, SRF, DF, EAC and moment capacity corroded beams

\begin{tabular}{|c|c|c|c|c|c|c|}
\hline $\begin{array}{l}\text { Beam } \\
\text { Group }\end{array}$ & $\begin{array}{c}\text { Beam } \\
\text { No. }\end{array}$ & Beam Type & $\begin{array}{l}\mathrm{SRF} \\
\mathrm{Pu} / \mathrm{Pc}_{\mathrm{c}}\end{array}$ & $\begin{array}{c}D F \\
\left(D_{u} / D_{c}\right)\end{array}$ & $\begin{array}{l}\text { EAC, } 85 \% \\
\text { of } \\
\text { ultimate } \\
\text { load (J) }\end{array}$ & $\begin{array}{c}\text { Moment } \\
\text { capacity }(k N-m)\end{array}$ \\
\hline \multirow{3}{*}{$\triangleright$} & A1-C & FULL SCC & 1.34 & 2.08 & 481 & 12.48 \\
\hline & A2-C & FULL LWSCC & 1.44 & 5.95 & 1197 & 13.42 \\
\hline & A3-C & FULL ECC & 1.12 & 1.80 & 1665 & 18.69 \\
\hline \multirow{5}{*}{ ద } & B1-C & ECC100+SCC125 & 1.20 & 1.53 & 496 & 15.25 \\
\hline & B2-C & ECC100+LWSCC125 & 1.35 & 2.23 & 533 & 15.28 \\
\hline & B3-C & $\begin{array}{l}\text { LWSCC+ECC14 } \\
\text { wrapping }\end{array}$ & 1.15 & 2.78 & 1143 & 15.37 \\
\hline & B4-C & ECC50+SCC150 & 1.49 & 3.51 & 506 & 15.94 \\
\hline & $\mathrm{B} 5-\mathrm{C}$ & ECC50+LWSCC150 & 1.62 & 2.30 & 281 & 12.98 \\
\hline \multirow{3}{*}{$n$} & $\mathrm{C} 1-\mathrm{C}$ & LWSCC +.25\% PVA & 1.28 & 6.63 & 952 & 8.52 \\
\hline & $\mathrm{C} 2-\mathrm{C}$ & LWSCC + 1\% CR & 1.12 & 1.63 & 200 & 7.50 \\
\hline & C3-C & LWSCC + 1\% HDPE & 1.44 & 1.76 & 273 & 10.54 \\
\hline
\end{tabular}




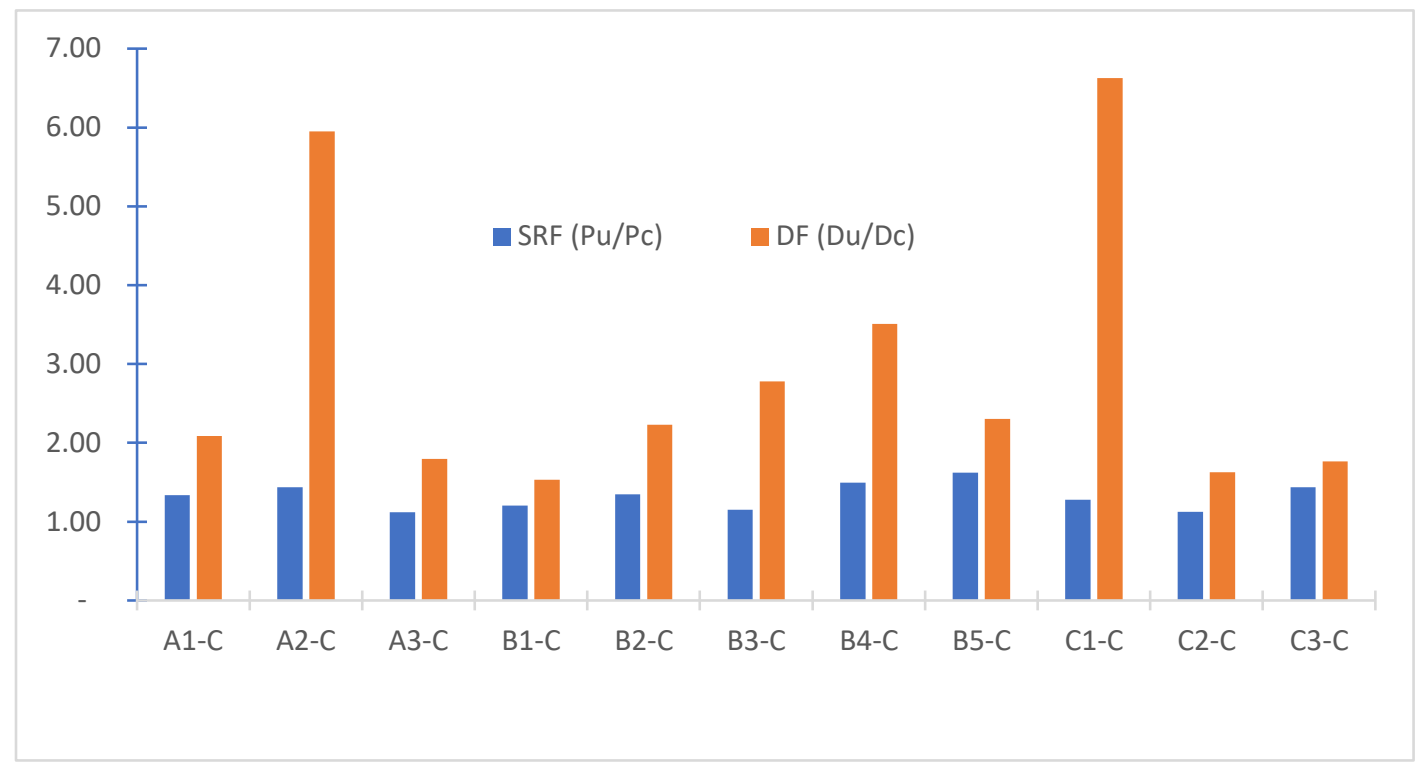

Figure 4-25: Comparisons of SRF and DF of corroded beams

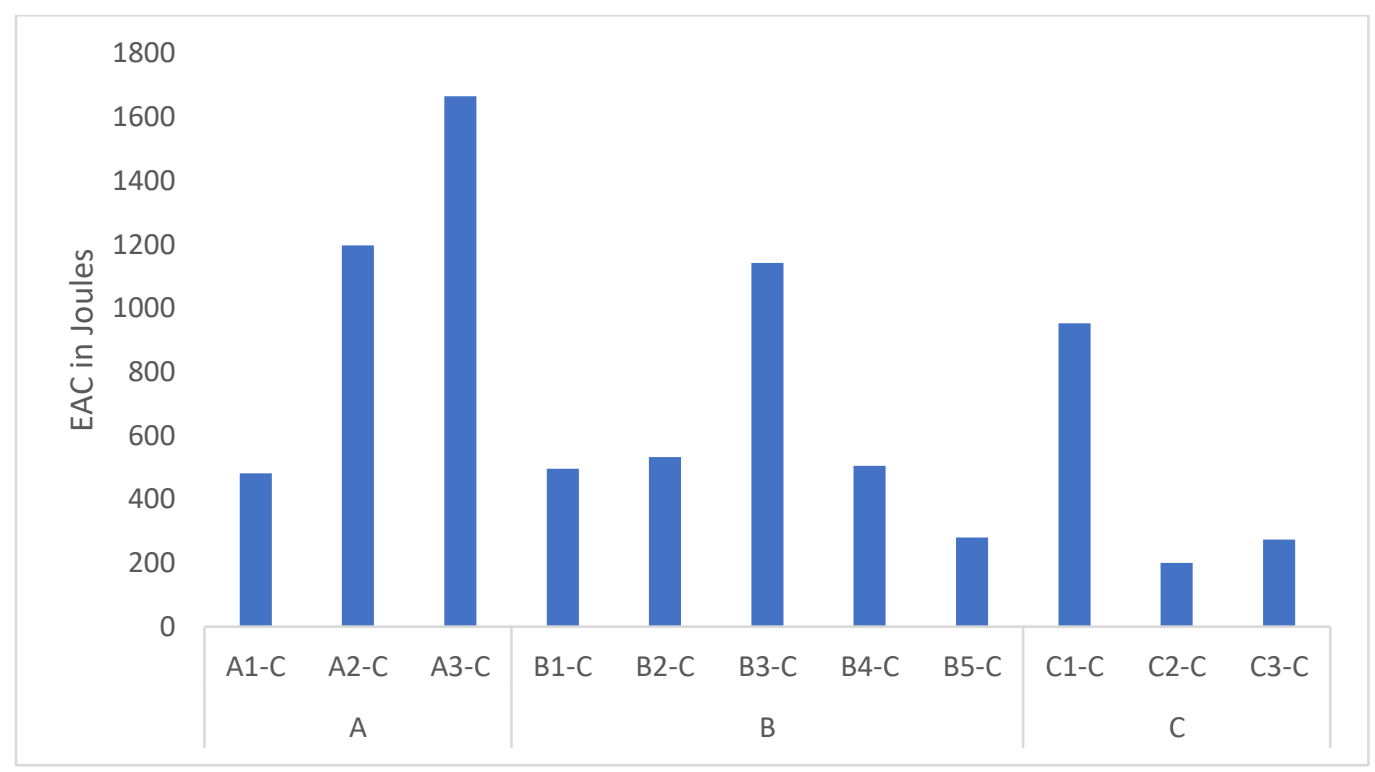

Figure 4-26: EAC of corroded beams 


\subsubsection{Comparative load-deflection behavior and failure mode- uncorroded and corroded beams}

Figures 4-27 to 4-37 compares load-deflection response of companion uncorroded and corroded beam. The higher deflection was observed in the corroded beams as expected due to corrosion induced concrete damage/softening and deterioration of reinforcement. This result supports the findings of previous research studies confirming increase in mid-span deflections with the increase of corrosion at higher failure load regardless of the concrete type (Hariche et al., 2012). The performance in terms of the load-deflection response of corroded beams was different from fresh uncorroded beams. On an average, up to $50-60 \%$ of the failure load, both (fresh and corroded) beams showed the similar slope, then corroded beams exhibited lower or decreasing slope compared to uncorroded beams. The increased slope of the load-deflection curve could be related to the increase of the beam's ductility which resulted from the reduction of the longitudinal bar diameter due to corrosion, especially at midspan. Figure 4-29 shows that corroded beam full depth ECC/A3-C and composite beam LWSCC+ECC wrapping B3-C exhibited slightly higher constant slope (stiffness) up to 87\% and $85 \%$ of failure load of uncorroded beams. Beam FRLWSCC+HDPE/C3-C exhibited slightly lower constant slope (stiffness) up to $83 \%$ of failure load of the uncorroded beam. In addition, beams A3, B3 and C3 confirmed the lower strength loss $16.05 \%, 11.75 \%, 15.88 \%$ respectively compared to the other beams in their respective beams groups. This confirmed superior corrosion resistance of full-depth ECC beam compared to its SCC or LWSCC counterparts, composite beam with ECC wrapping compared to its ECC layer counterparts and FRLWSCC beam with HDPE fiber compared its PVA or CR counterparts in terms of higher residual failure load. Figure 4-38 shows deflection variation of uncorroded and corroded beams. 


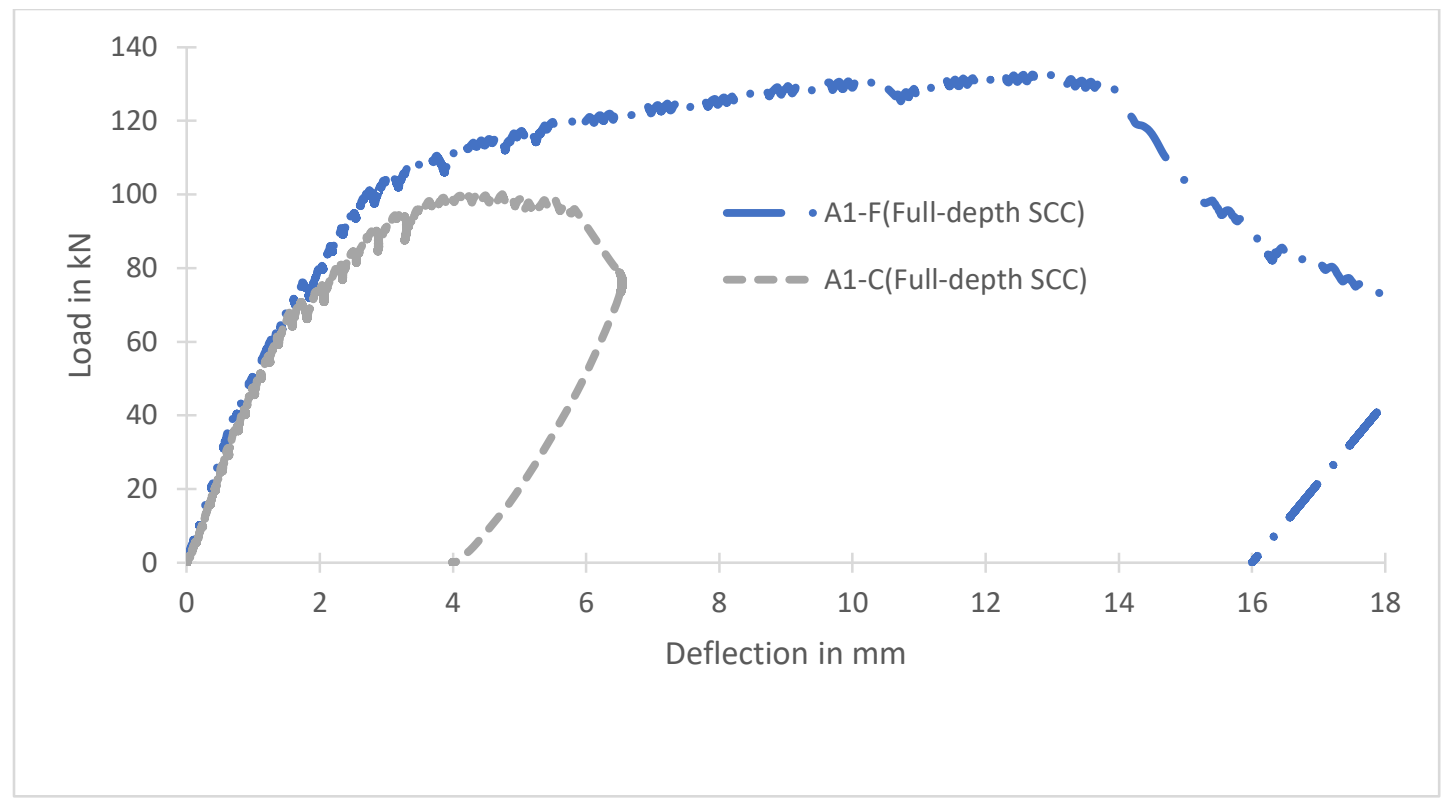

Figure 4-27: Load vs deflection curve of beams A1-F and A1-C

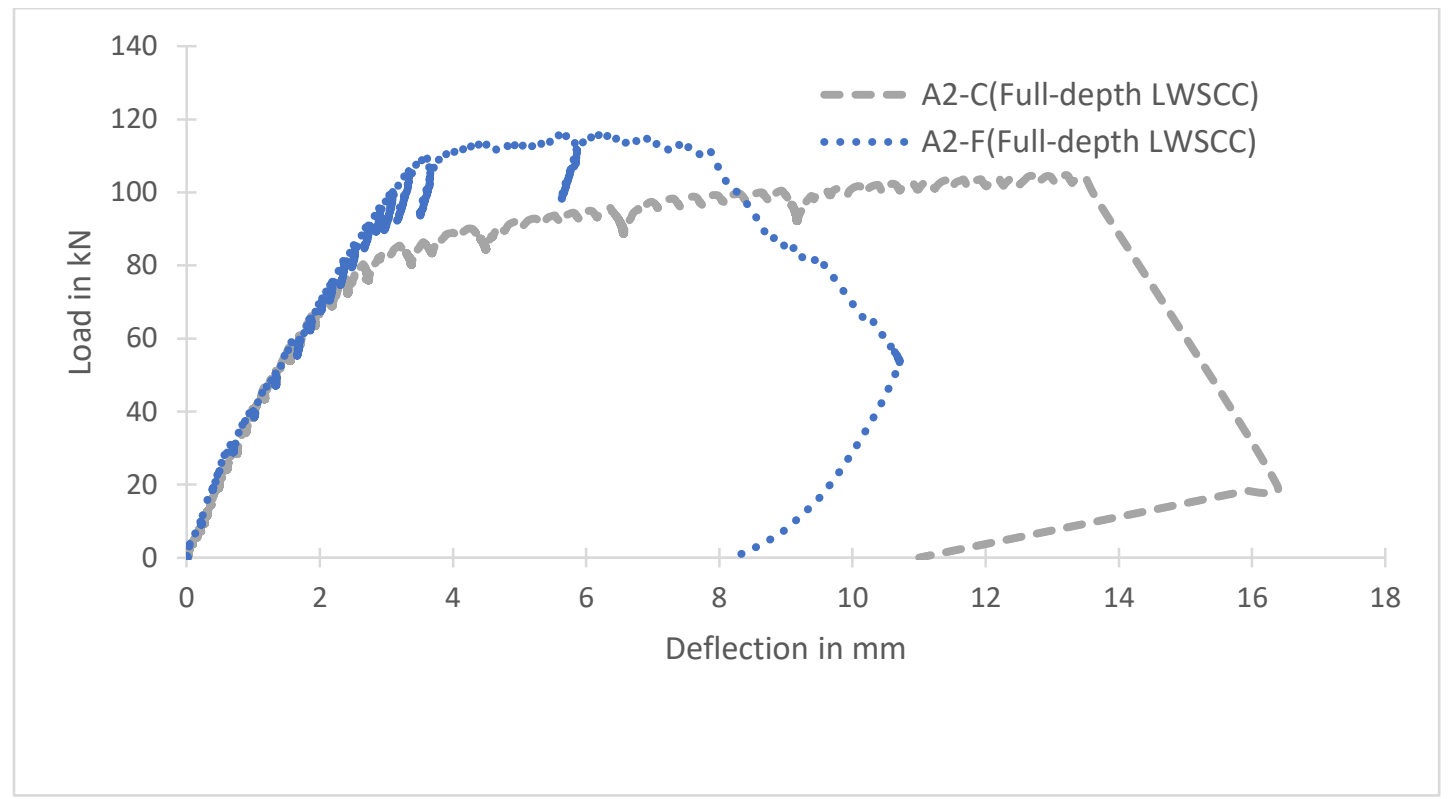

Figure 4-28: Load vs deflection curve of beams A2-F and A2-C 


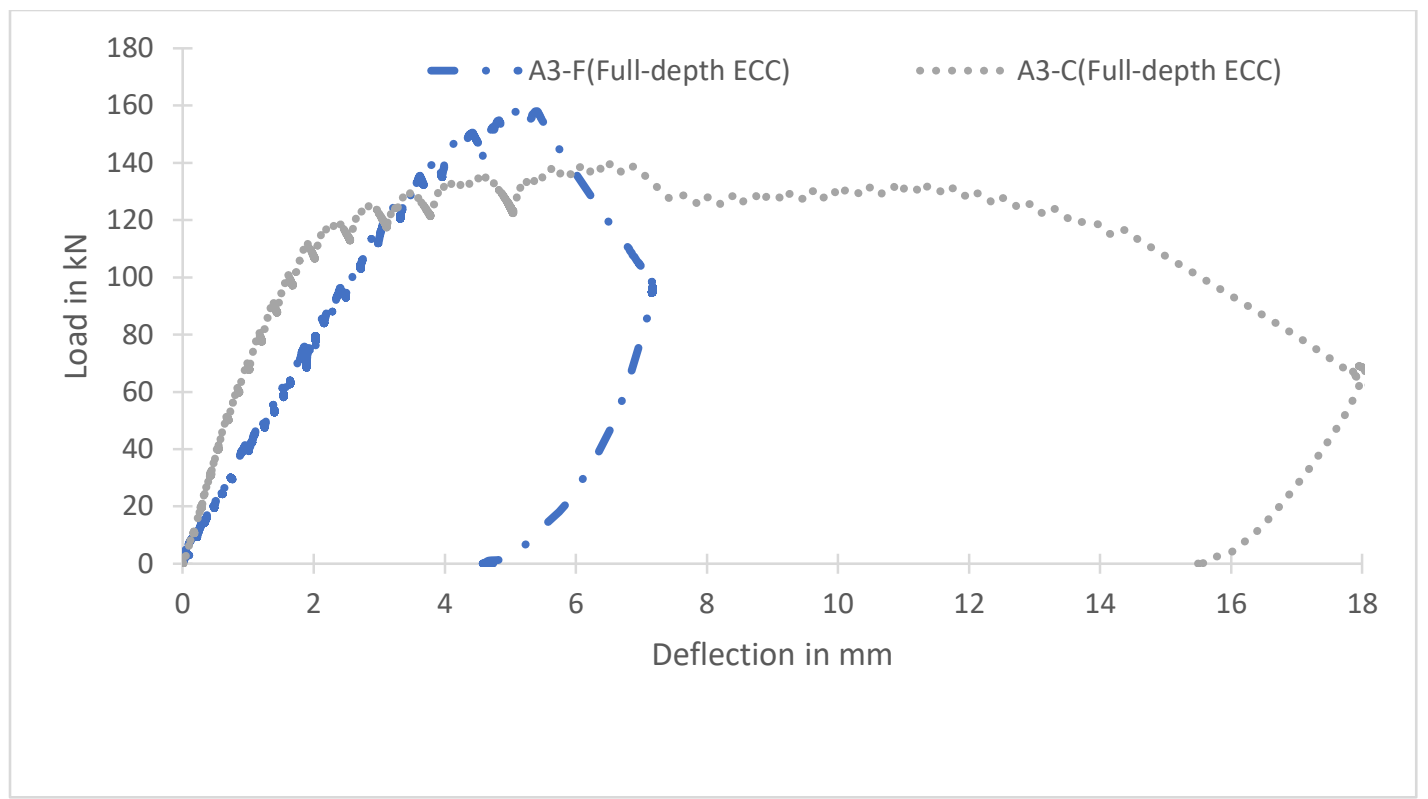

Figure 4-29: Load vs deflection curve of beams A3-F and A3-C

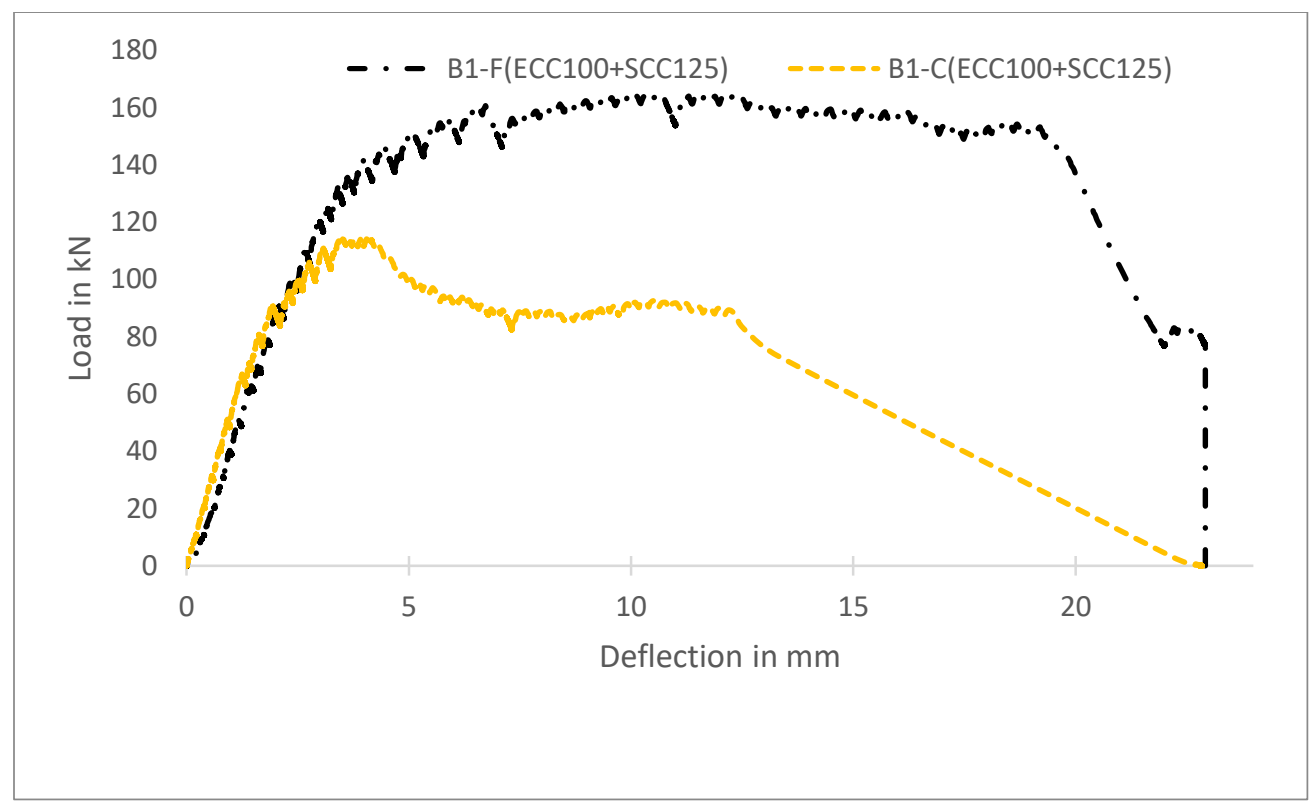

Figure 4-30: Load vs deflection curve of beams B1-F and B1-C 


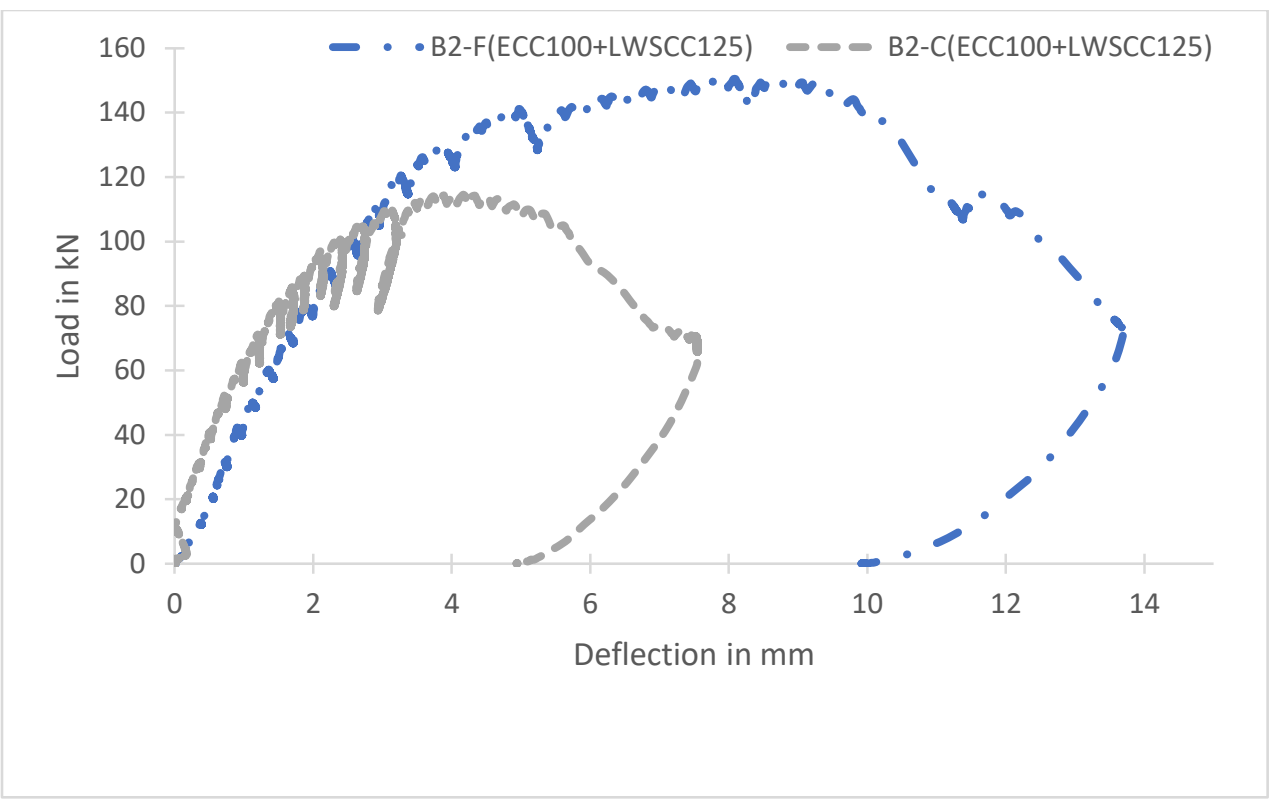

Figure 4-31: Load vs deflection curve of beams B2-F and B2-C

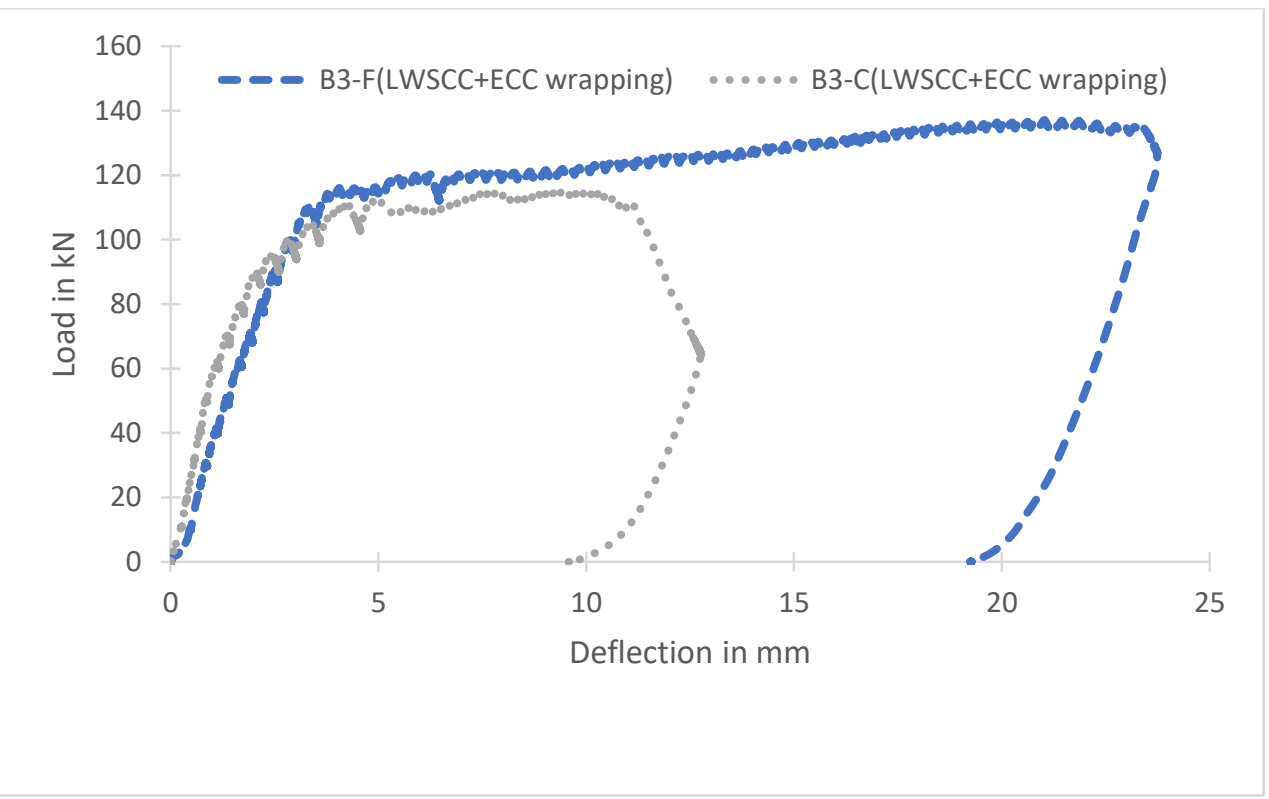

Figure 4-32: Load vs deflection curve of beams B3-F and B3-C 


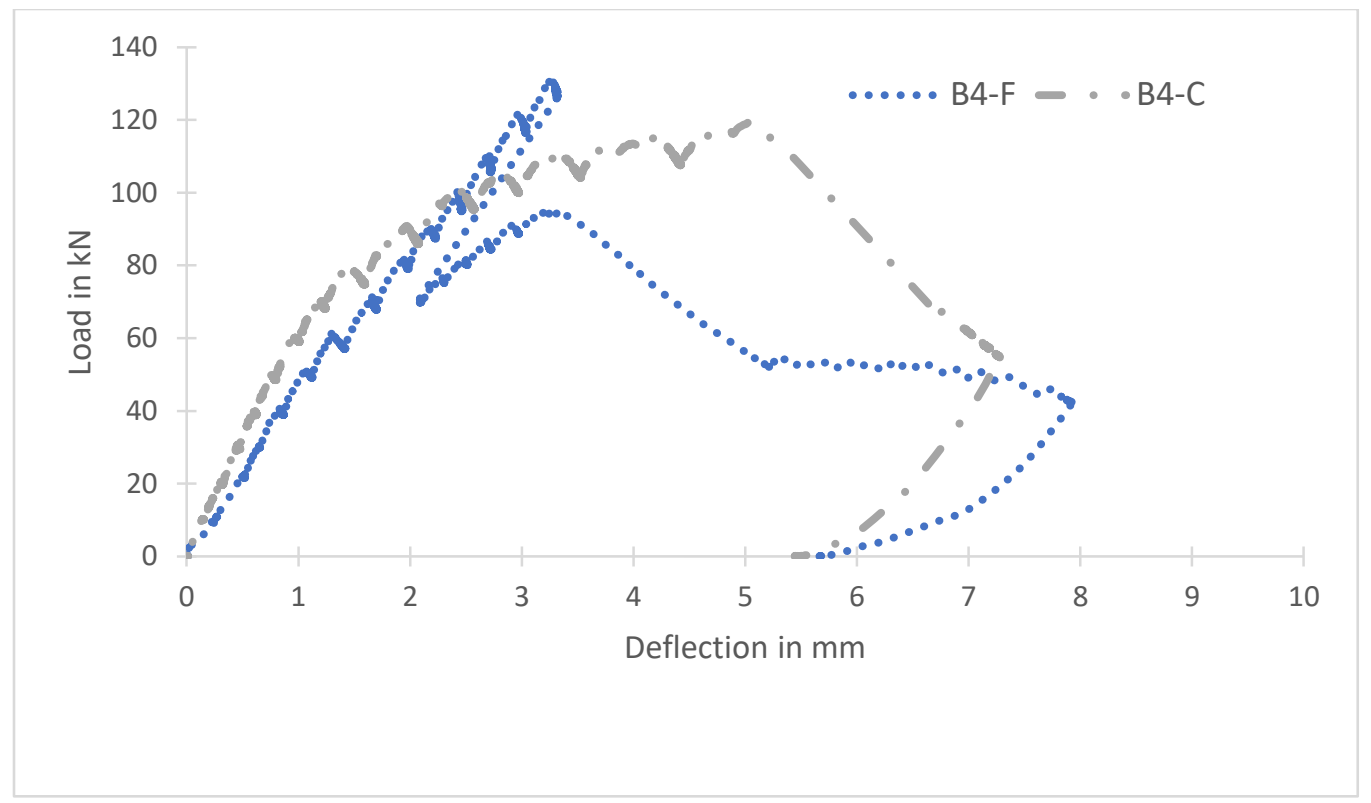

Figure 4-33: Load vs deflection curve of beams B4-F and B4-C

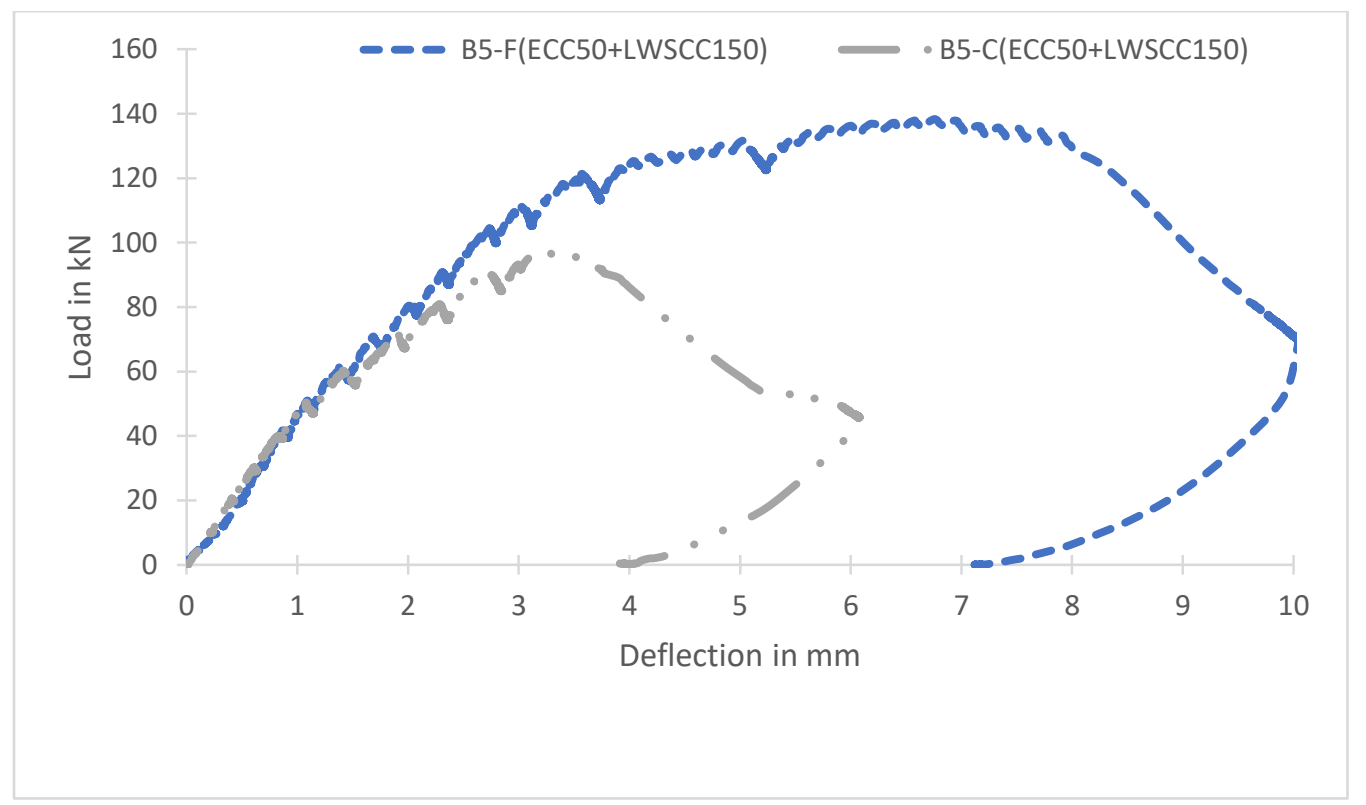

Figure 4-34: Load vs deflection curve of beams B5-F and B5-C 


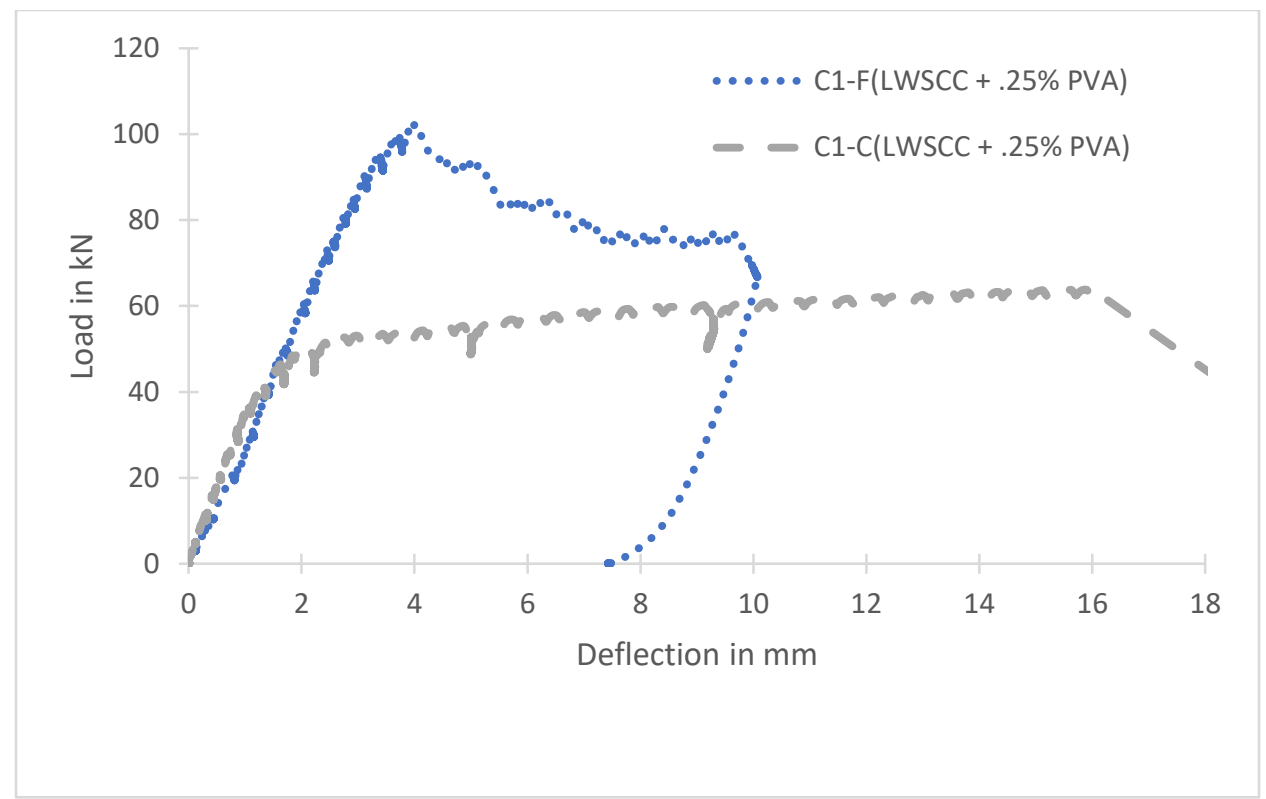

Figure 4-35: Load vs deflection curve of beams C1-F and C1-C

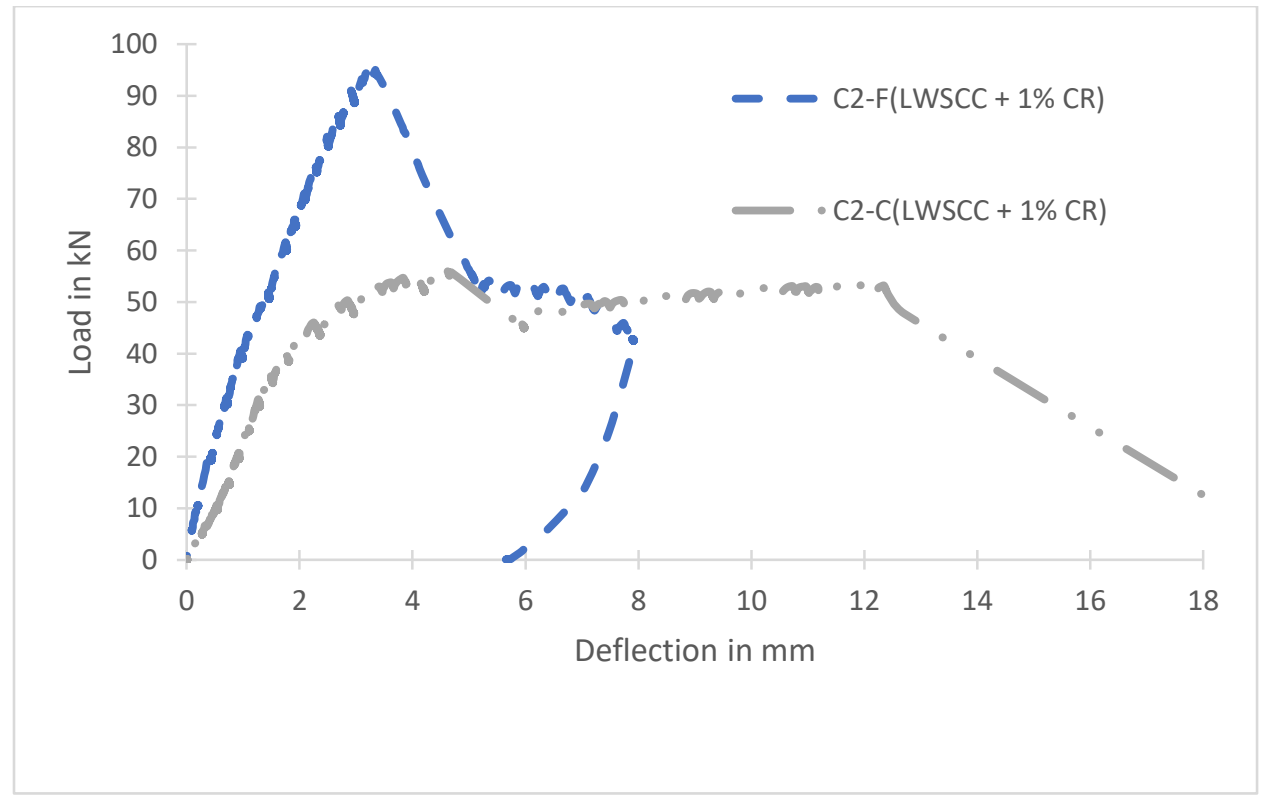

Figure 4-36: Load vs deflection curve of beams C2-F and C2-C 


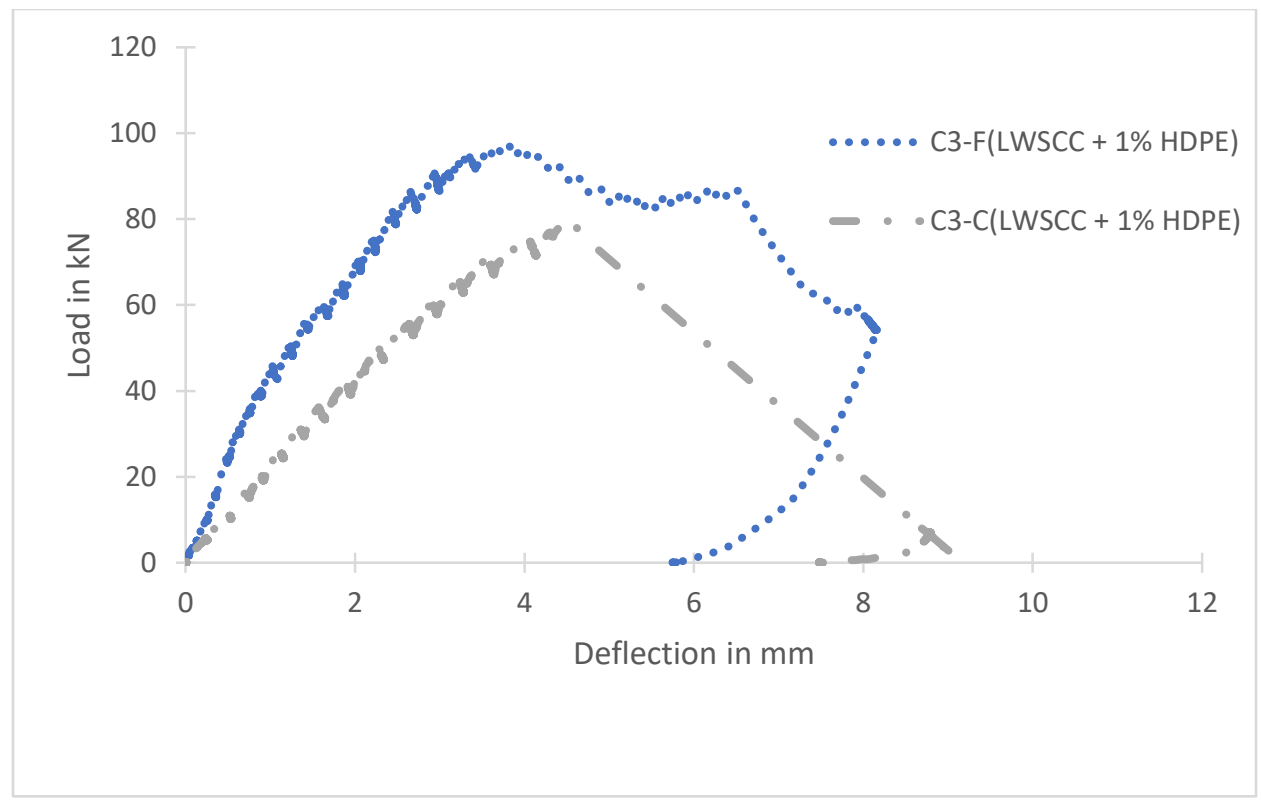

Figure 4-37: Load vs deflection curve of beams C3-F and C3-C

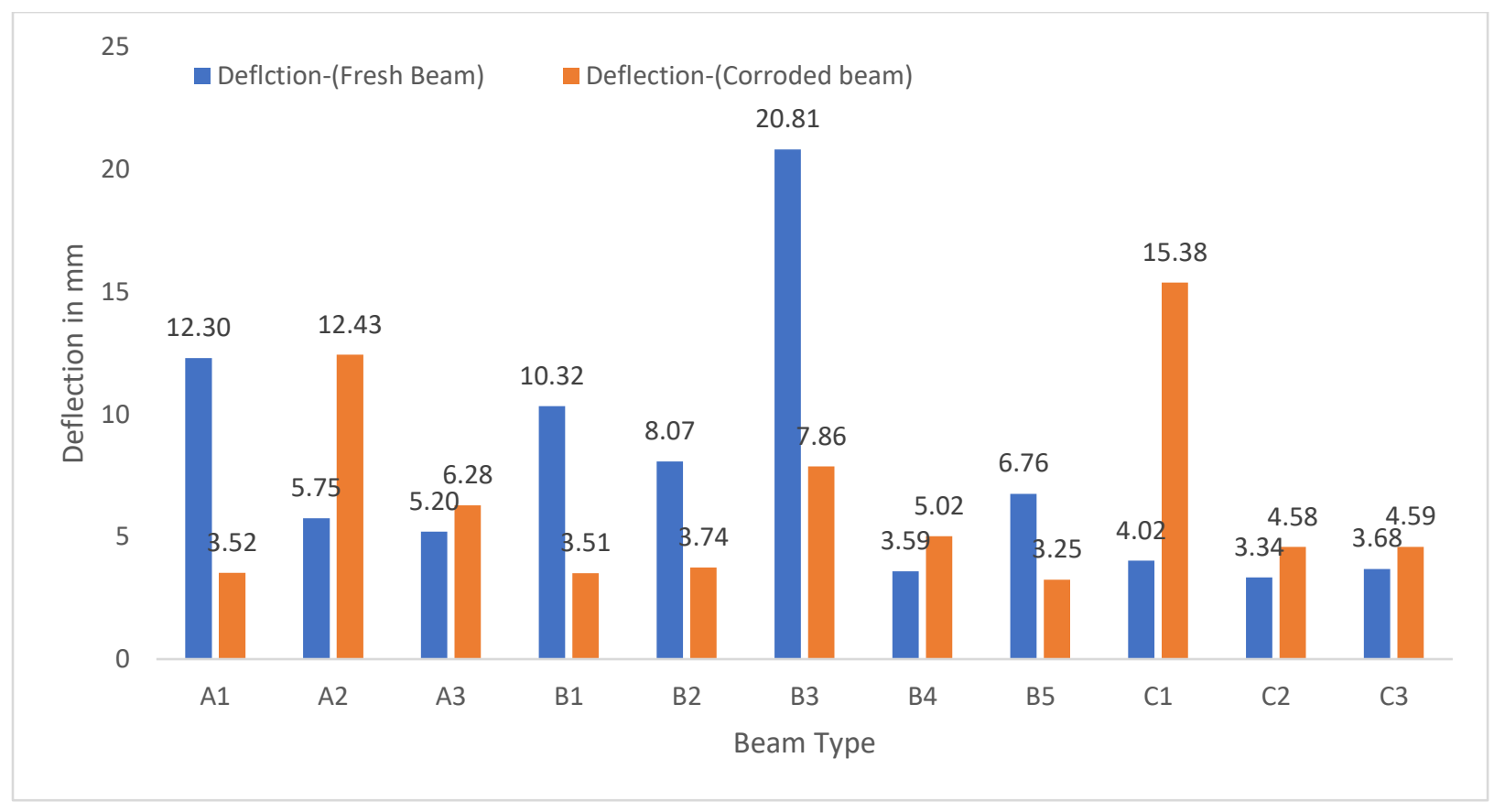

Figure 4-38: Deflection of uncorroded vs corroded beams 


\subsubsection{Post-cracking shear resistance, ductility and energy absorption capacity of uncorroded and corroded beams}

Figure 4-20 and 4-25 show the comparisons of SRF and DF of uncorroded and corroded beams. Uncorroded full depth SCC (SRF=1.34), LWSCC (SRF=2.90) and composite beams with LWSCC $(\mathrm{SRF}=2.31)$ exhibited higher $\mathrm{SRF}$ because of the presence of a higher percentage of aggregate (especially coarse aggregate in SCC and LWSCC. On the other hand, shear ductility in terms of DF of "Full depth SCC" and composite beam LWSCC + ECC wrapping were higher than all other uncorroded beams. On the other hand, in corroded beams, higher SRF was found in full depth LWSCC/A2-C with SRF of 1.44, composite beam B2-C (ECC100+LWSCC125) with SRF of 1.15, composite beam B4 (ECC50+SCC150) with SRF of 1.49 and C3-C (LWSCC+1\%HDPE) with SRF of 1.44. On the other higher DF was associated with beams A2-C (full depth LWSCC) with DF of 5.95 and C1-C (LWSCC+0.25\% PVA) with DF of 6.63 due to high percentage of corrosion and spalling in these beams.

Figure 4-39 compares the energy absorption capacity of corroded and uncorroded beams. In general, uncorroded beams exhibited high energy absorption capacity than corroded beams. The uncorroded composite beams $\mathrm{B} 1-\mathrm{F}(\mathrm{ECC} 100+\mathrm{SCC} 125)$ and $\mathrm{B} 3-\mathrm{F}$ (LWSCC+ECC wrapping) showed superior energy absorption capacity with 2802.5 joules and 2721.5 joules, respectively. Corroded beams A3-C/full depth ECC (1665 joule), B3-C/LWSCC+ECC wrapping (1142.5 joules) and C1/LWSCC+0.25\% PVA (952.0 joules) showed high energy absorption capacity from each group. That means corrosion decreased the stiffness and increase the EAC.

Figure 4-40 shows the comparison of ultimate failure loads and percentage strength loss of uncorroded and corroded beams. A lower percentage of strength loss exhibited of the beams A3/full depth ECC (11.75\%), B3/LWSCC+ECC wrapping (16.05) and C3/LWSCC+1\%HDPE $(15.88 \%)$ from each group. Overall composite beam C2-C (LWSCC+1\%CR) exhibited higher strength loss. 


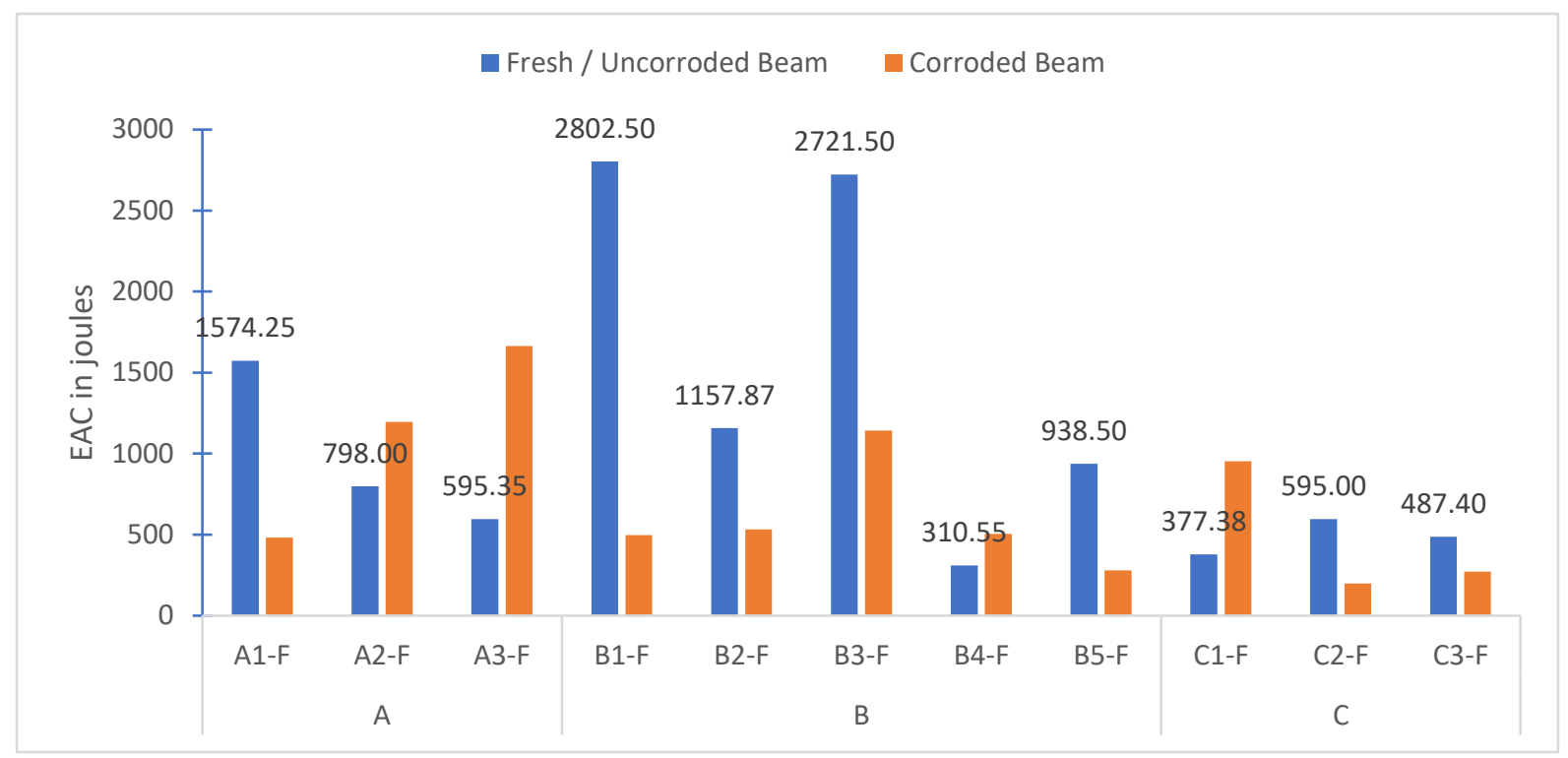

Figure 4- 39: Energy absorption capacity of fresh-uncorroded and corroded beams

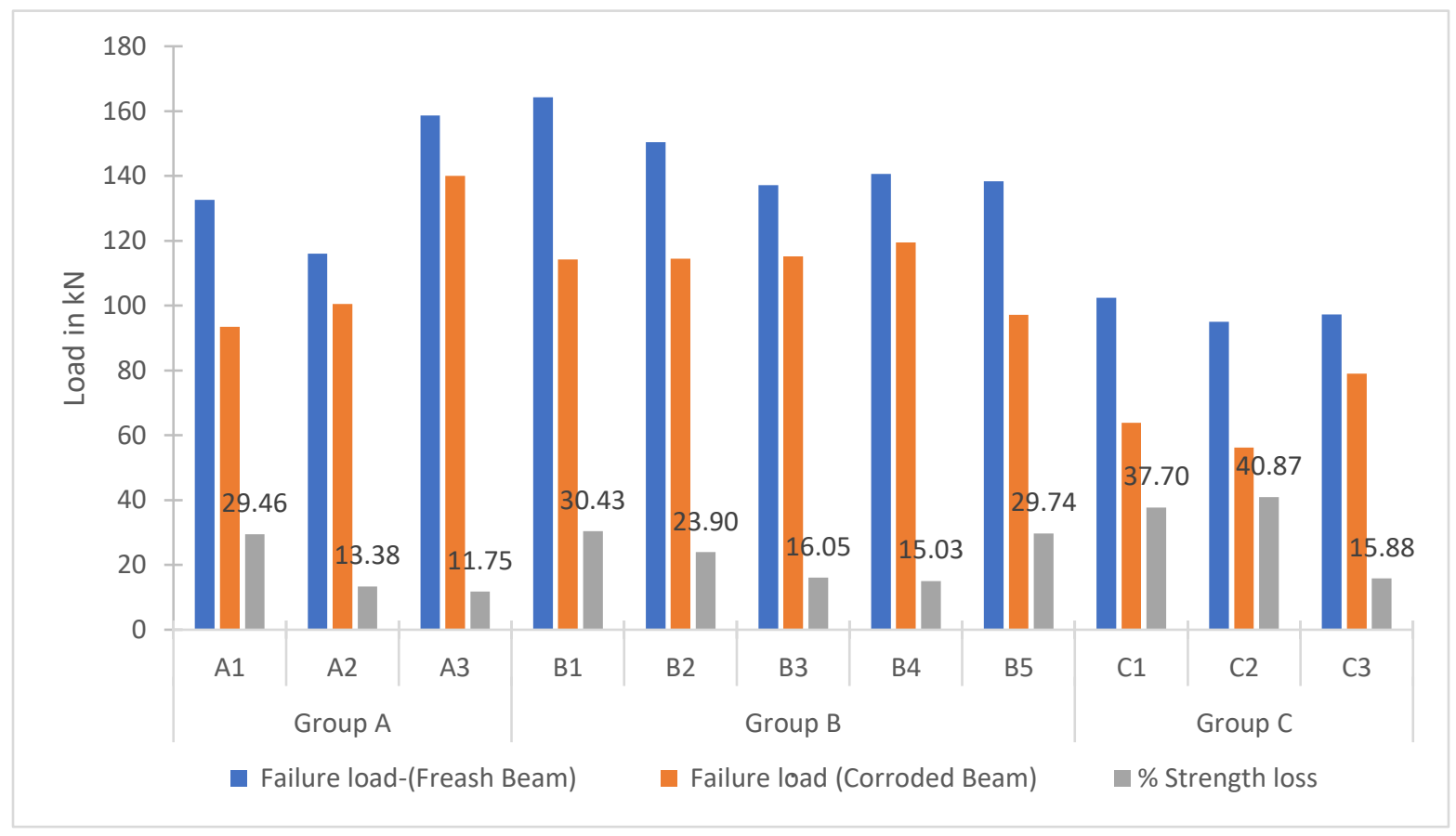

Figure 4-40: Ultimate failure load of uncorroded, corroded beams and percentage of strength loss 


\subsubsection{Corrosion-induced concrete damage}

\subsubsection{Cracking response}

The opening of cracks in concrete structure vary from one structure to another and the role of cracks in reinforcement corrosion is meaningless (Yu, François, Dang, L'Hostis, \& Gagné, 2015). Figure 4-41 shows the failure pattern of Beam A2-C (Full depth LWSCC). The beam developed flexure and shear cracks, however, it failed in shear. All 22 beams were designed and cast as a shear beam with shear span and depth $(\mathrm{a} / \mathrm{d})$ ratio 1.53. Figures B-1 to B-3 in Appendix A show the failure mode and cracking pattern of beams. Table 4-9 summarizes the failure modes and corrosion induced cracking or damage of corroded beams.

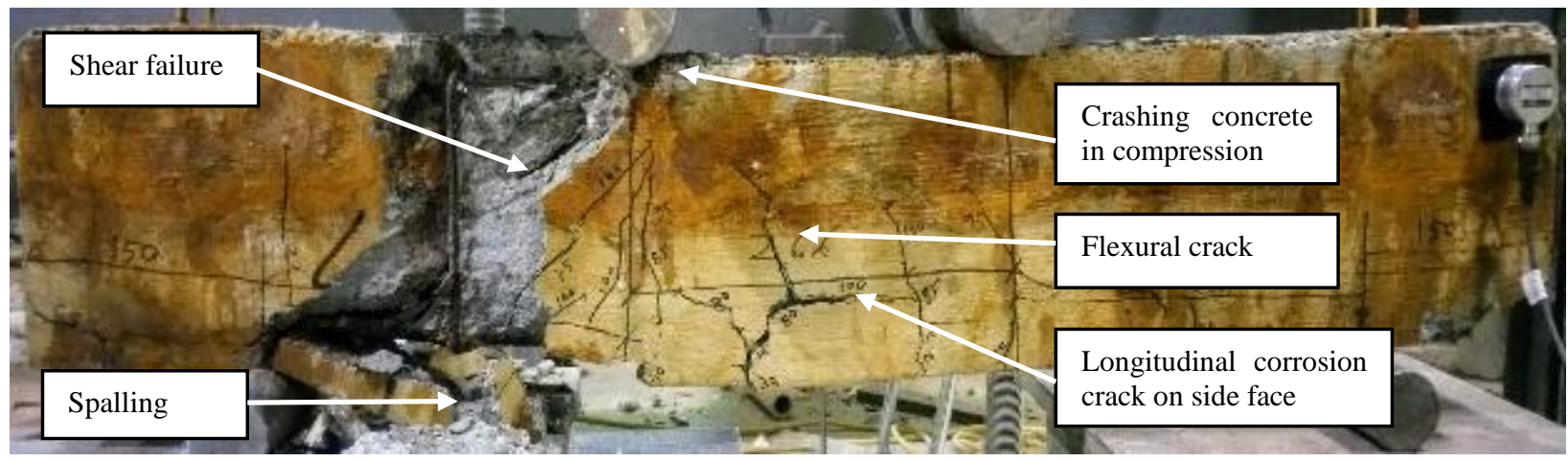

Figure 4-41: Failure mode of Beam A2

The corrosion severely affected the failure mode and the load capacity due to high mass loss (average 32.78\%). This mass loss lead to the enormous loss of bond and cross-sectional area of the reinforcing steel bars, in addition to the effect associated with corrosion induced cracks. The bond between a corroded bar and its surrounding concrete deteriorates and the effective crosssectional area of a corroded bar decreases. 
Table 4-8: Summary of corroded beams failure mode and observation

\begin{tabular}{|c|c|c|c|c|c|c|c|}
\hline $\begin{array}{c}\text { Beam } \\
\text { Grou } \\
p\end{array}$ & $\begin{array}{l}\text { Beam } \\
\text { No. }\end{array}$ & Beam Type & $\begin{array}{l}\text { Failure } \\
\text { pattern }\end{array}$ & $\begin{array}{c}\% \\
\text { Actual } \\
\text { mass } \\
\text { loss }\end{array}$ & $\begin{array}{c}\% \\
\text { Strength } \\
\text { loss }\end{array}$ & $\begin{array}{c}\% \\
\text { Moment } \\
\text { loss }\end{array}$ & Remarks \\
\hline \multirow{3}{*}{$>$} & A1-C & Full-depth SCC & Shear & 33.17 & 29.46 & $29 \%$ & $\begin{array}{l}\text { Spalling at bottom, one } \\
\text { side }\end{array}$ \\
\hline & A2-C & Full-depth LWSCC & Shear & 31.93 & 13.38 & $13 \%$ & $\begin{array}{l}\text { Cover spalling at shear } \\
\text { zone }\end{array}$ \\
\hline & A3-C & Full-depth ECC & flexure & 27.23 & 11.75 & $12 \%$ & No cover spalling \\
\hline \multirow{5}{*}{$\infty$} & B1-C & ECC100+SCC125 & flexure & 30.51 & 30.43 & $30 \%$ & No cover spalling \\
\hline & B2-C & $\begin{array}{l}\text { ECC100+LWSCC12 } \\
5\end{array}$ & Shear & 32.86 & 23.90 & $24 \%$ & No cover spalling \\
\hline & B3-C & $\begin{array}{l}\text { LWSCC+ECC } \\
\text { rapping }\end{array}$ & Shear & 38.43 & 16.05 & $16 \%$ & No cover spalling \\
\hline & B4-C & ECC $50+S C C 150$ & Shear & 31.81 & 15.03 & $9 \%$ & $\begin{array}{l}\text { Spalling on stirrup in } \\
\text { shear zone }\end{array}$ \\
\hline & B5-C & ECC50+LWSCC150 & Shear & 29.46 & 29.74 & $30 \%$ & No cover spalling \\
\hline \multirow{3}{*}{$\Omega$} & $\mathrm{C} 1-\mathrm{C}$ & LWSCC $+.25 \%$ PVA & Flexure & 40.87 & 37.70 & $38 \%$ & Spalling at bottom \\
\hline & $\mathrm{C} 2-\mathrm{C}$ & LWSCC + $1 \%$ CR & Flexure & 36.88 & 40.87 & $41 \%$ & Spalling at bottom \\
\hline & $\mathrm{C} 3-\mathrm{C}$ & LWSCC + $1 \%$ HDPE & Shear & 27.41 & 15.88 & $19 \%$ & spalling at on end \\
\hline
\end{tabular}

As a result, both failure modes and ultimate strength of corroded beams were altered (Dua, Cullen, $\& \mathrm{Li}, 2013)$. The corrosion cracks showed a big influence on failure mode. The beams A1-C, A2$\mathrm{C}, \mathrm{C} 1-\mathrm{C}, \mathrm{C} 2-\mathrm{C}$, and C3-C in this category showed spalling at the bottom (Table 4-9) with beam B4-C showing spalling along the stirrups. Nevertheless, the flexural capacity is reduced more than the shear capacity in advanced corrosion level, hence the failure mode changes from shear to pure flexure in some beams in post-corrosion structural testing (Zhu, François, Coronelli, \& Cleland, 2013).

\subsubsection{Effect of cover depth}

Two different concrete cover depth was used in the research. Composite beams, B1(ECC100+SCC125) and B2 (ECC100+LWSCC125) had $45 \mathrm{~mm}$ clear cover for the tensile bar while 20mm clear cover was used for rest of the beams. Beam B1 and B2 exhibited superior corrosion resistance than other composite beams (B3, B4, B5) and sustained 18 days' corrosion test. Though beam B3 (LWSCC with ECC wrapping) continued 18 days corrosion test, it exhibited higher (38.4\%) bar mass loss. On the other hand, B1 and B2 showed 30.5\% and 32.9\% mass loss respectively. This result was supported by the previous experiment that was done by $\mathrm{Yu}$ et al. 2015. Chloride concentration varies in concrete in different depth, the high concentration found 
on the surface of concrete and decrease with the increase of concrete depth from the surface. So, the reinforcement is well protected in beams with higher cover depth. Even though the passive film is destroyed over time, the corrosion rate can be restricted by increasing the cover depth, because high cover depth ensures limited oxygen supply for cathodic reaction (Yu, François, Dang, L'Hostis, \& Gagné, 2015). ACI 318 recommends a minimum cover thickness of $37.5 \mathrm{~mm}$ and 50 $\mathrm{mm}$ where de-icing salt is used and ACI 357 recommends a minimum of $65 \mathrm{~mm}$ in marine structure. (ACI 357, 1997).

\subsubsection{Effect of ECC layer embedding reinforcement}

Composite beams were made with two different thickness (100 mm and 50mm) of ECC layer embedding reinforcement to prevent corrosion with SCC or LWSCC in Beams B1 $(\mathrm{ECC} 100+\mathrm{SCC} 125), \quad \mathrm{B} 2 \quad(\mathrm{ECC} 100+\mathrm{LWSCC} 125), \quad \mathrm{B} 4 \quad(\mathrm{ECC} 50+\mathrm{SCC} 150)$ and $\mathrm{B} 5$ (ECC50+LWSCC150). Beams B1 and B2 had ECC layer depth of 45\% of beam depth while. Beams B4 and B5 had 25\%. However, all beams maintained similar effective depth (d) of 175mm, shear span to effective depth ratio $(\mathrm{a} / \mathrm{d})$ of 1.53 and reinforcement ratio of 1.14.

$\checkmark$ Structural performance of uncorroded beams:

The performance of beams B1-F, B2-F, B4-F and B5-F was compared with their full depth SCC/A1-F and LWSCC/A2-F counterparts based on ultimate load/moment capacity and energy absorption capacity (EAC).

Full depth SCC/A1-F and its companion composite beam B4-F(ECC50+SCC150) showed similar pre-cracking stiffness and ultimate load or moment capacity. Beam A1-F showed 400\% higher energy absorption capacity than beam B4-F. Full depth LWSCC/A2-F beam and its companion composite beam B5-F (ECC50+LWSCC150) exhibited similar stiffness but beam B5-F had $19.23 \%$ higher ultimate load and 18\% higher energy absorption capacity. Composite beam B1F(ECC100+SCC125) exhibited 24\% higher ultimate load, 78\% higher energy absorption capacity than its companion A1-F (full depth SCC). Composite beam B2-F(ECC100+LWSCC125) exhibited 30\% higher ultimate load and 45\% higher energy absorption capacity than its full depth LWSCC counterparts, beam A2-F. This results support previous research, application of a layer of ECC on the tensile side of a beam increased its flexural strength and the degree of improvement increased with the thickness of ECC (Hasib 2016; Hasib and Hossain, 2016). In addition, ECC layer enhanced the ductility of the beam and the failure mode changed from brittle to ductile (Hasib 2016; Hasib, \& Hossain, 2016; Leung et al., 2007). For the better purpose of ductility 
improvement, the smallest thickness of the ECC layer must be over 30\% of the beam depth (Zhang, Wang, Ju, \& Shi, 2014). This confirmed the beneficial effect of using ECC layer in improving ultimate load (up to $30 \%$ as observed in this study) observed and energy absorbing capacity (up to $78 \%$ ) of SCC and LWSCC beams.

$\checkmark$ Corrosion resistance performance:

The beams A1-C (full depth SCC), A2-C (full depth LWSCC) and B4-C (ECC50+SCC150), B5(ECC50+LWSCC150) sustained accelerated corrosion test for 18days while B1-C (ECC100+SCC125) and B2-C(ECC100+LWSCC150) sustained 11days. Composite beams B4-C and B5-C showed better performance regarding the cracking and spalling than their full depth A1$\mathrm{C}$ and A2-C counterparts, however, they showed very similar mass loss. Flexural strength loss was A1-C (29.46\%), A2-C (13.38\%), B4-C (15.03\%) and B4-C (29.74\%). The beams B1-C and B2-C exhibited superior performance than their counterpart A1-C and A2-C regarding cracking and spalling. This results indicated that higher ECC layer increased the corrosion resistance performance of composite beams compared to their full depth SCC or LWSCC counterparts.

\subsubsection{Effect of ECC wrapping}

The un-corroded composite beam B3-F (LWSCC+ 14 mm ECC wrapping) showed 18\% higher ultimate load capacity, 240\% higher energy absorption capacity, 260\% higher deflection and 64\% higher ductility factor than its full-depth corroded LWSCC counterpart A2-F. In addition, corroded composite beam B3-F (LWSCC+ $14 \mathrm{~mm}$ ECC wrapping) showed superior corrosion resistance performance regarding cracking, spalling and surviving accelerated corrosion test for longer duration (18 days compared 11 days) than its A2-C counterparts which showed cracking $(0.25 \mathrm{~mm}$ to $1.00 \mathrm{~mm}$ ) at the bottom. This clearly shows the beneficial effect of using ECC wrapping around LWSCC core to improve structural and corrosion performance.

\subsection{Summary}

In this chapter, the corrosion resistance performance of full depth (SCC, LWSCC and ECC) composite (ECC+SCC and ECC+LWSCC with ECC layer or wrapping) and FRLWSCC (with PVA, CR and HDPE fiber) were described based on experimental results and physical observations. Full depth ECC Beam /A3, from group A, composite beams ECC100+SCC125/B1, and LWSCC + ECC wrapping/B3 from Group B and LWSCC+1\%HDPE/C3 from group C showed the superior performance against corrosion. Full depth ECC Beam (A3) showed lowest mass loss (27.23\%) and strength loss (11.75\%) in group A. Beam B1 exhibited lowest mass loss 
(30.51\%) and strength loss (30.43\%) and small spalling at both end. However, B3 showed higher mass loss (38.43\%) due to more days of accelerated corrosion but lower strength loss (16.05\%) without any crack. The structural performance of corroded beams is also described compared to their corroded counterparts based ultimate load, deflection capacity, energy absorbing capacity and other parameters including cracking, failure modes and bar mass loss. The beneficial effect of ECC layer or wrapping covering reinforcement and beam core on structural and corrosion performance is also proved and described. The detailed finding of this chapter will be presented in Chapter 5. 


\section{CHAPTER 5 : CONCLUSIONS AND RECOMMENDATIONS}

\subsection{Summary}

In this research twenty-two reinforced beams made of self-consolidating concrete (SCC), lightweight SCC (LWSCC), fiber reinforced LWSCC (FRLWSCC), Engineered cementitious composite (ECC) and their combinations were built to analyze for corrosion resistance performance. All beams were divided into three groups, group A (full depth SCC, LWSCC and ECC), group B (Composite beams- ECC-SCC/LWSCC having ECC layer or wrapping) and group $\mathrm{C}$ (full depth FRLWSCC). The main variables in the study were types of concrete, corrosion test duration, clear cover of the rebar, ECC layer thickness in composite beams and different types of fiber (Polyvinyl alcohol 'PVA', crumb rubber 'CR' and high-density polyethylene 'HDPE') used in FRLWSCC beams. The corrosion resistance performance of eleven corroded beams were analyzed based on the current measurements, half-cell potential readings, crack pattern, crack width, rebar mass loss and diameter reduction from accelerated corrosion tests. 11 Furthermore, corroded and their companion 11 uncorroded beams were tested to failure under simply supported four-point loading to evaluate load-deflection response, crack pattern, $1^{\text {st }}$ flexure/diagonal cracking load, failure modes and load at failure. The performance of corroded and uncorded beams were critically analyzed and compared based on load-deflection response, the degradation of strength, ductility, energy absorbing capacity, cracking and modes of failure. The effect of all the variables including ECC layer or wrapping on the structural and corrosion performance was also analyzed.

\subsection{Conclusions}

Based on the results of this research program, the following conclusions were drawn:

- Full depth beams in Group A- full depth ECC beam showed superior corrosion resistance performance compared to its SCC and LWSCC counterparts based on actual bar mass loss, diameter loss, strength loss, crack pattern, the number of crack and half-cell potential measurements. Full depth ECC beam showed better corrosion resistance than their SCC or LWSCC counterparts by retaining higher (40 to 50\% higher) post-corroded strength with failure mode also changing from shear to flexure. There for full depth ECC beams exhibited the best corrosion resistance followed by full depth SCC and LWSCC beams.

- Composite beams with ECC layer in Group B- composite beam B1(100mm ECC layer and $125 \mathrm{~mm}$ SCC layer) and B2 (100 mm ECC layer and $125 \mathrm{~mm}$ LWSCC layer) exhibited similar superior corrosion resistance based on test results compared to their counterparts 
having ECC layer of less thickness $(50 \mathrm{~mm})$. An increase in the thickness of ECC layer increased the corrosion resistance of composite beams. Composite beam with ECC wrapping showed better corrosion resistance compared to its ECC layer counterparts in terms of higher residual failure load. ECC wrapping around the beam core was more effective than ECC layer covering reinforcement in improving corrosion resistance.

- Full depth FRLWSCC beams in Group C- HDPE-FRLWSCC beam exhibited superior corrosion resistance compared its PVA-FRLWSCC and CR-FRLWSCC counterparts in terms of mass loss, strength loss, crack pattern and spalling in group C.

- Higher ECC layer thickness increased the corrosion resistance performance of composite beams compared to their full depth SCC or LWSCC counterparts.

- Corroded composite beam B3-F (LWSCC+ $14 \mathrm{~mm}$ ECC wrapping) showed superior corrosion resistance performance regarding cracking, spalling and surviving accelerated corrosion test for longer duration (18 days compared to 11 days) than its full-depth LWSCC counterpart which showed cracking $(0.25 \mathrm{~mm}$ to $1.00 \mathrm{~mm})$ at the bottom. ECC wrapping also reduced the number of corrosion induced cracks significantly, This clearly showed the beneficial effect of using ECC wrapping around weak LWSCC core to improve structural and corrosion performance.

- Introducing fibers in LWSCC lead to decrease in stiffness and load capacity of FRLWSCC beams compared to their LWSCC counterpart in uncorroded state. In general, use of ECC layer or ECC wrapping increased the ultimate load and energy absorbing capacities of uncorroded composite beams compared to their full depth counterparts with ECC wrapping being the more effective. The use of ECC layer improved the ultimate load (up to $30 \%$ as observed in this study) and energy absorbing capacity (up to 78\%) of composite beams compared to full depth SCC and LWSCC beams.

- Theoretical rebar mass loss predicted by Faraday's law was lower (full depth SCC/A1) than the actual mass loss. This could be attributed to unaccounted natural corrosion while these samples were awaited for destructive testing and assumptions made in the theory. Actual rebar mass loss in corroded beams varied from $11.75 \%$ to $40.87 \%$ with $40.87 \%$ mass loss exhibited by full depth PVA-FRLWSCC beam and 11.75\% mass loss exhibited by full depth ECC beam. 
- Uncorroded beams exhibited a higher number of crack over their counter part of corroded beams during structural testing to failure.

- This study confirmed superior corrosion resistance of full-depth ECC beam compared to its SCC or LWSCC counterparts, composite beam with ECC wrapping compared to its ECC layer counterparts and FRLWSCC beam with HDPE fiber compared to its PVA or CR counterparts in exhibiting higher residual failure load.

- Overall the study confirmed the viability of using ECC beam a superior alternative to conventional concretes, using composite beams with ECC layer or wrapping particularly for LWSCC beam to improve corrosion resistance and structural performance in terms of strength, ductility and energy absorbing capacity enhancements.

\subsection{Recommendation for future research}

The following recommendations are made for future research studies:

- Investigate the corrosion resistance of full depth beams made of SCC, ECC, LWSCC and FRLWSCC in field conditions subjected to aggressive environment as well as in accelerated tests under service load. and ECC layer thickness under monotonic load.

- Investigate the corrosion resistance of composite beams with different ECC layer and wrapping thickness in combination with LWSCC and FRLWSCC.

- Investigate corrosion resistance and subsequent structural performance base on full-scale beams designed for both flexure and shear failure

- Perform finite element (FE) modeling of full depth and composite beams under corrosion environment based on experimental results.

- Investigate further corrosion resistance HDPE-FRLWSCC beams as they exhibited good corrosion resistance performance.

- Develop design procedures or modify Codes for prediction of shear and flexural strength of HPC beams investigated in this research with special reference to corrosion damage.

- Study the life cycle analysis of HPC beams investigated in this research compared to conventional concrete counterparts subjected to corrosion environment. 


\section{APPENDIX}

\section{Appendix A}

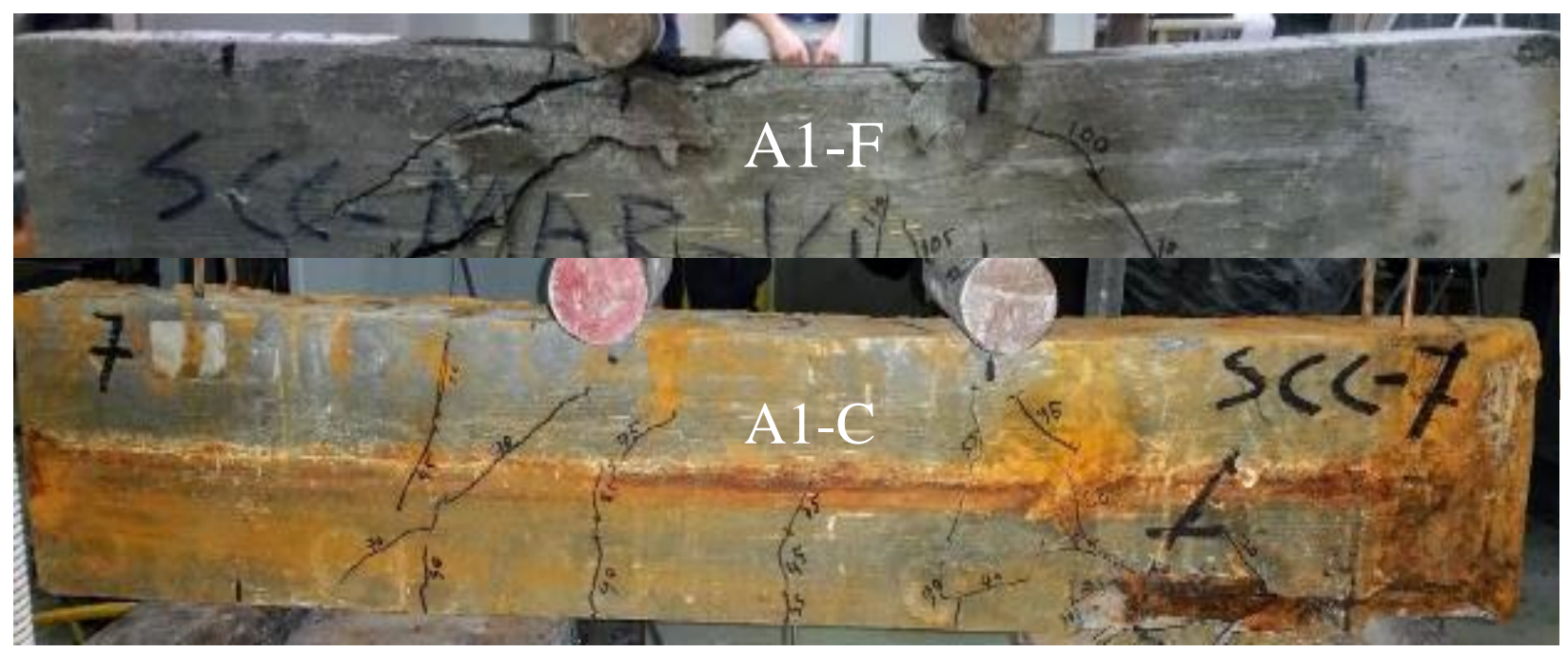

A- 1: Beams failure pattern after flexure and shear test of A1-F and A1-C

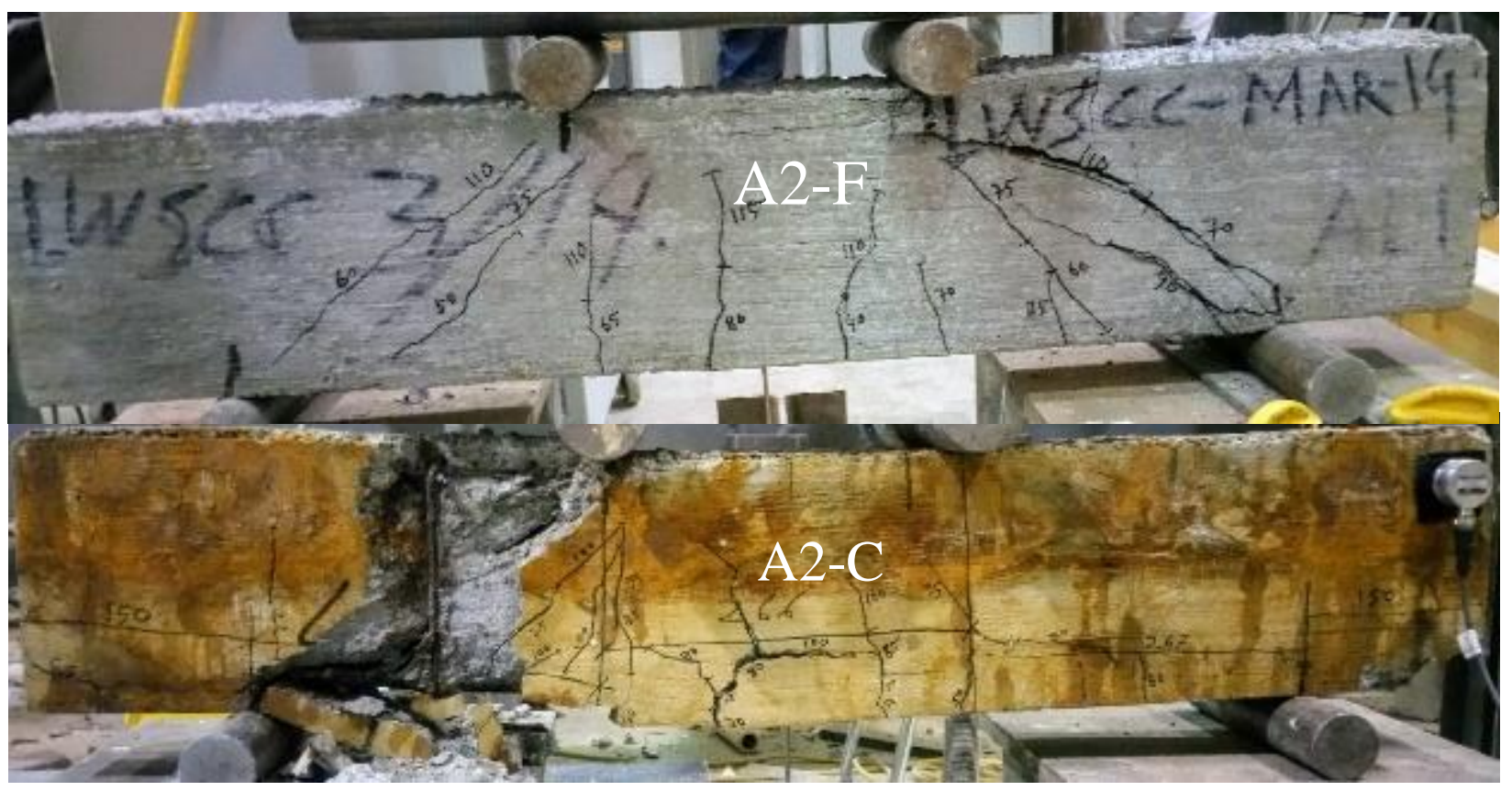

A- 2: Beams failure pattern after flexure and shear test of A2-F and A2-C 

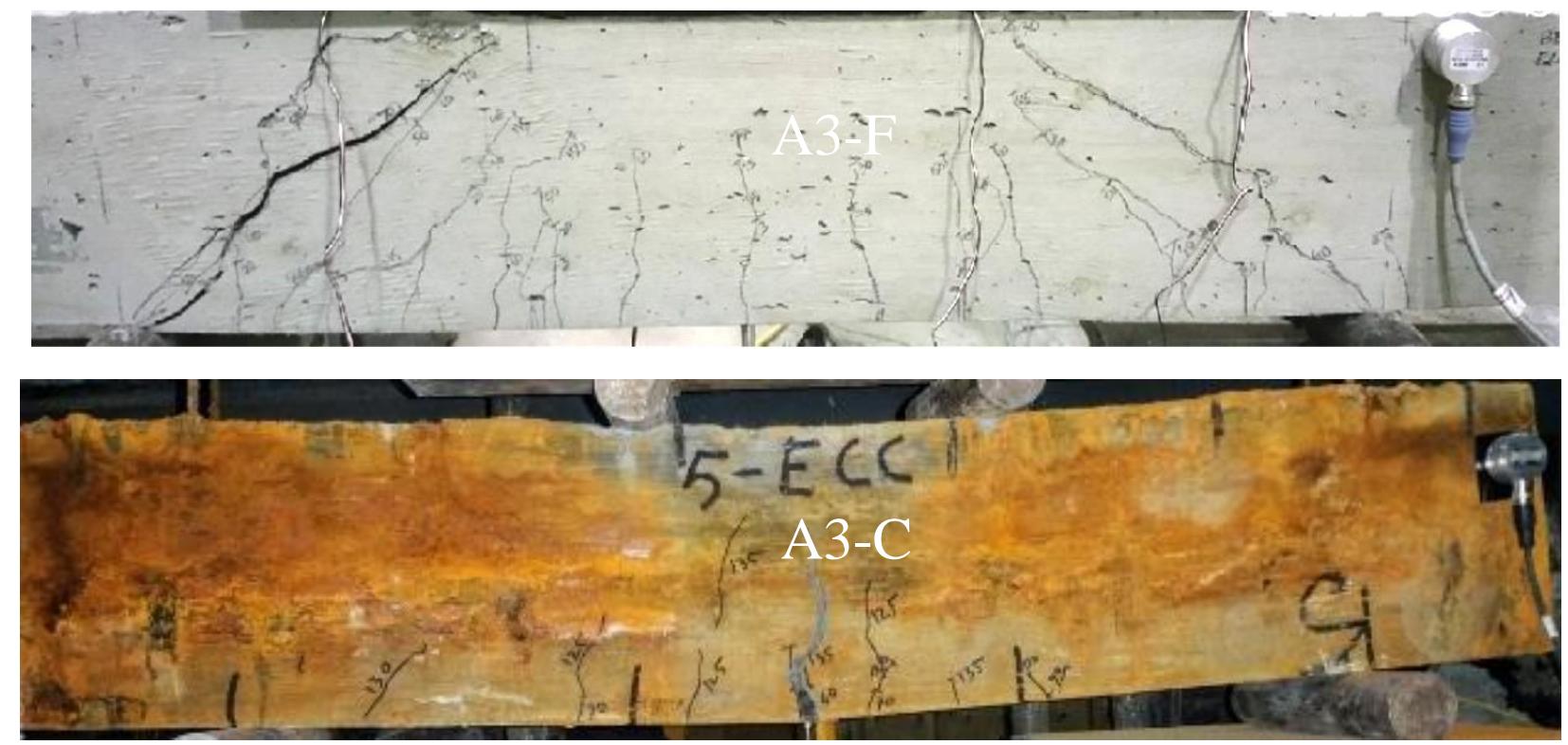

A- 3: Beams failure pattern after flexure and shear test of A3-F (Hasib,2016) and A3-C
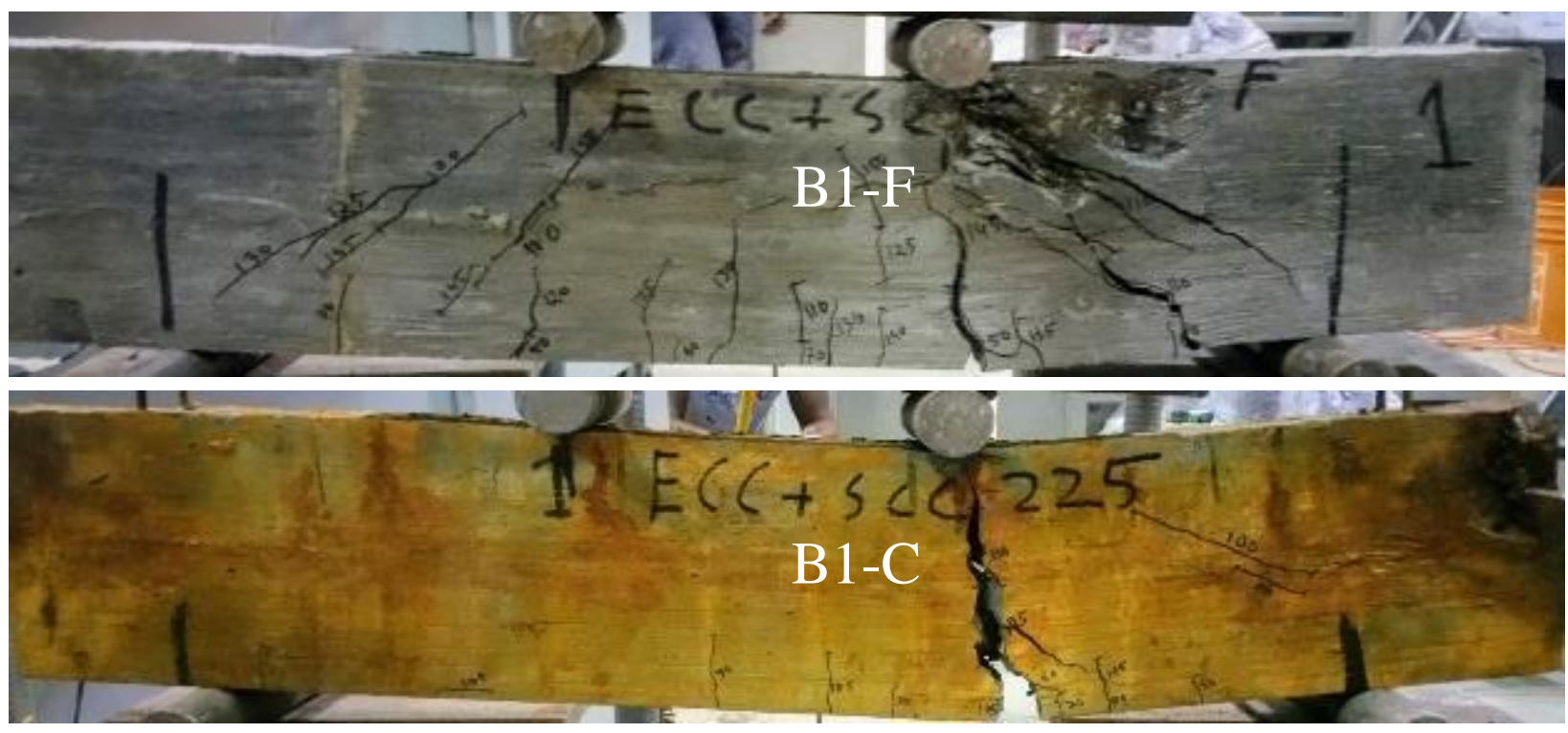

A- 4: Beams failure pattern after flexure and shear test of B1-F and B1-C 


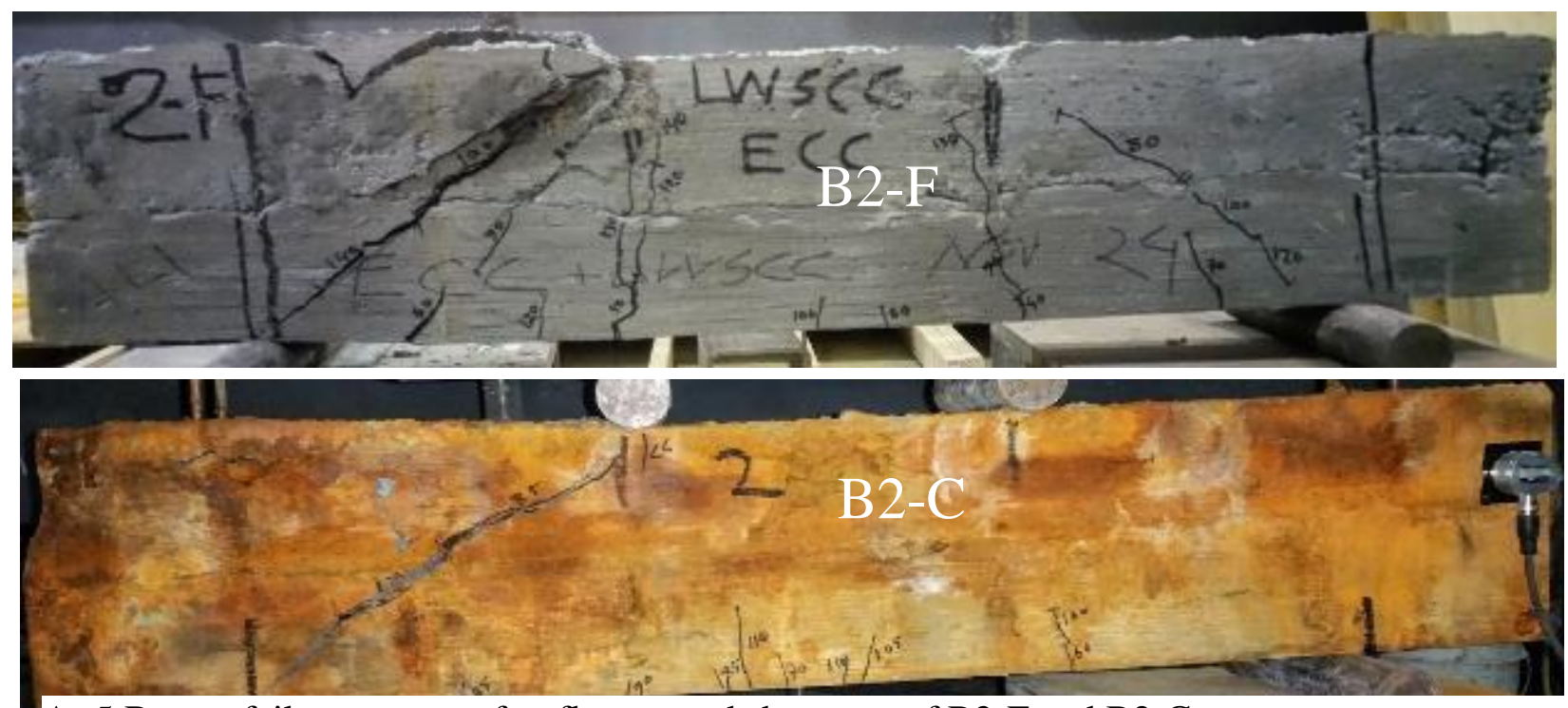

A- 5:Beams failure pattern after flexure and shear test of B2-F and B2-C
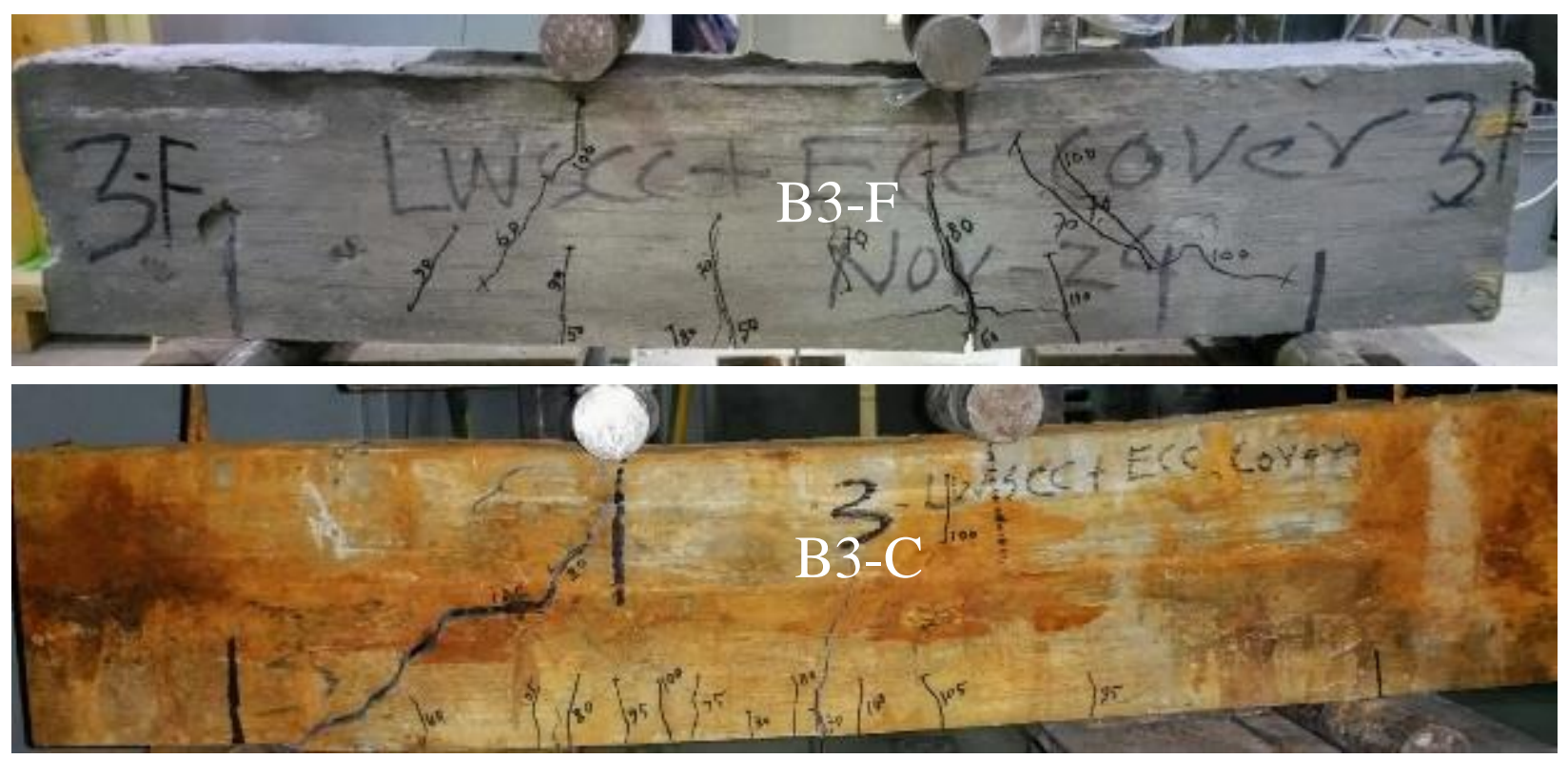

A- 6: Beams failure pattern after flexure and shear test of B3-F and B3-C 


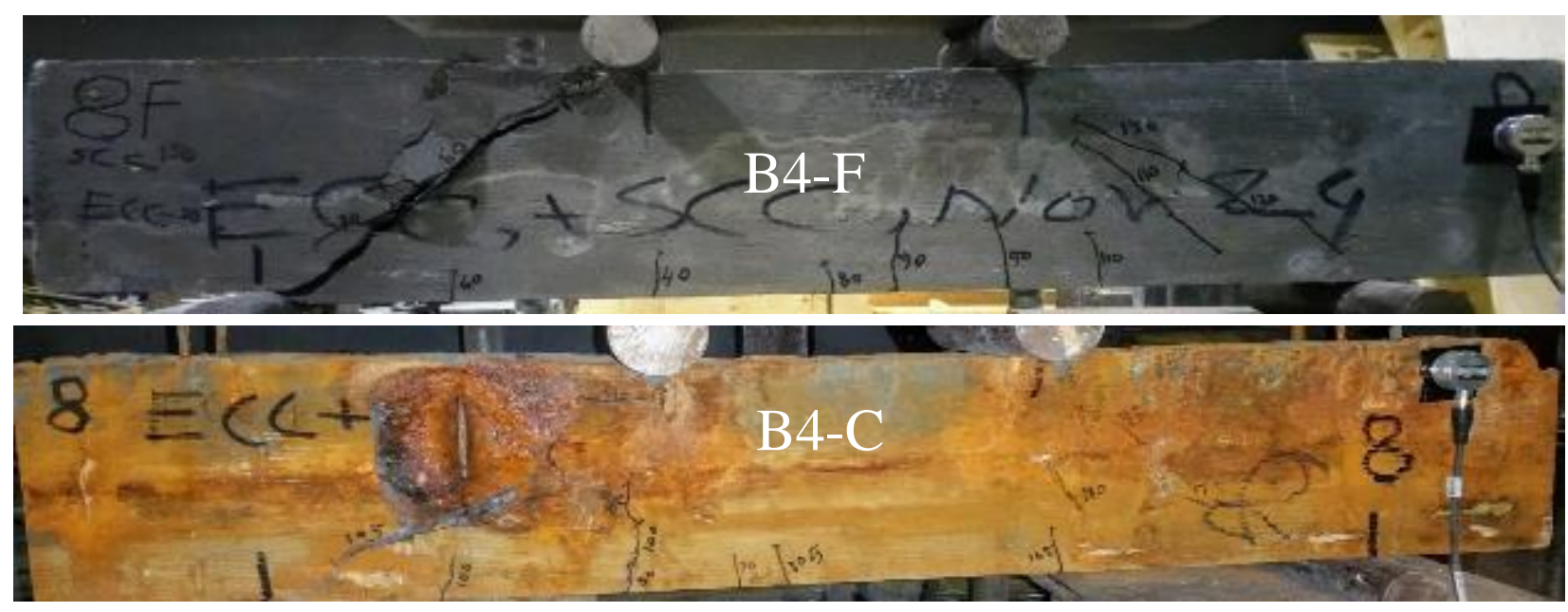

A- 7: Beams failure pattern after flexure and shear test of B4-F and B4-C

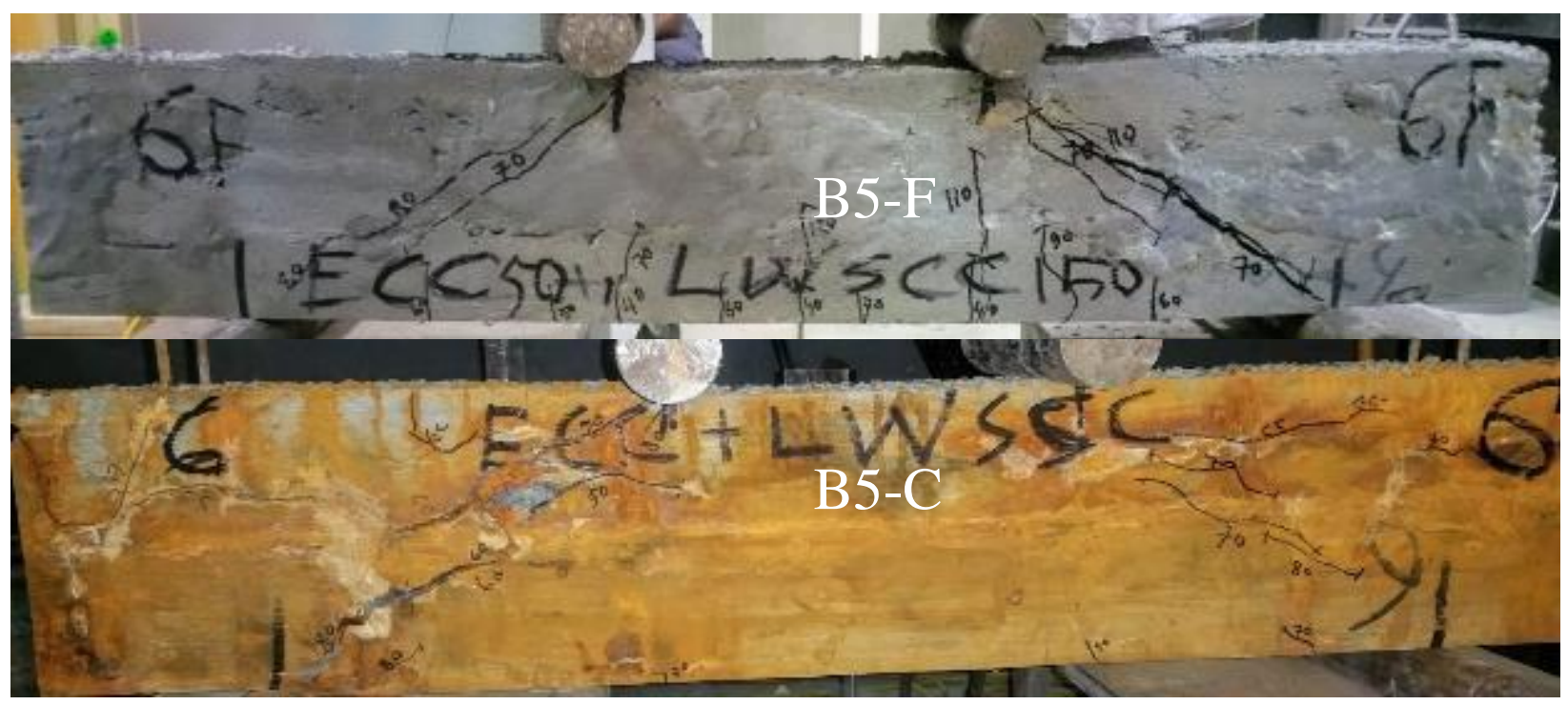

A- 8: Beams failure pattern after flexure and shear test of B5-F and B5-C 


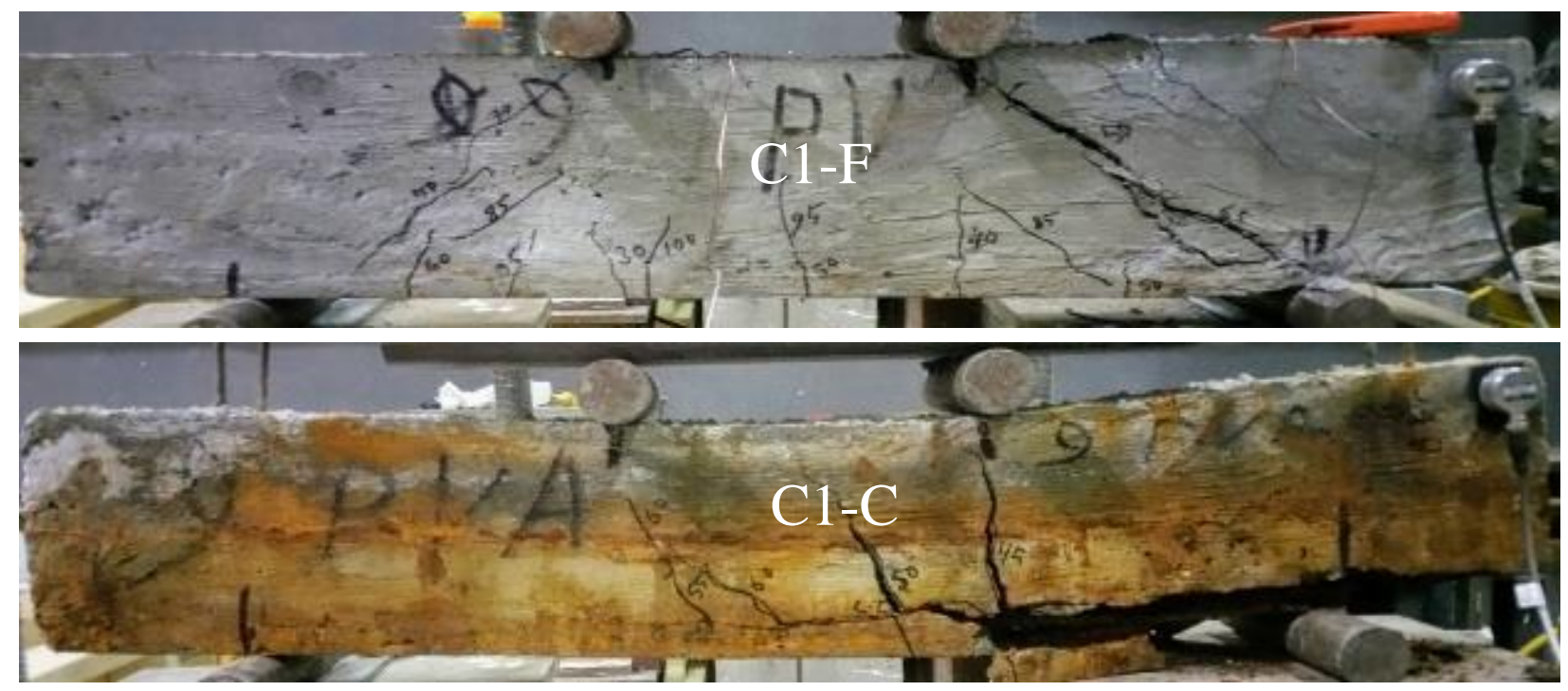

A- 9: Beams failure pattern after flexure and shear test of $\mathrm{C} 1-\mathrm{F}$ andC1-C
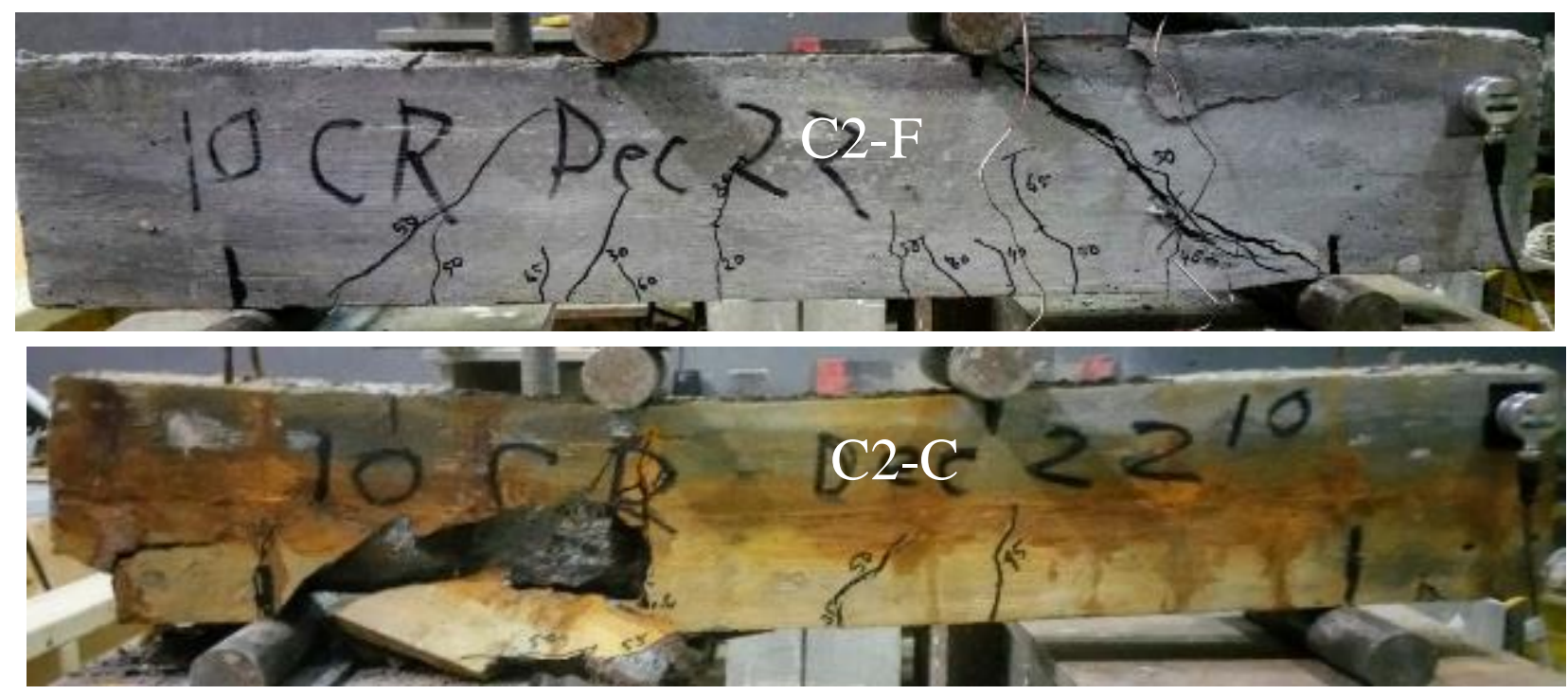

A- 10: Beams failure pattern after flexure and shear test of C2-F and C2-C 

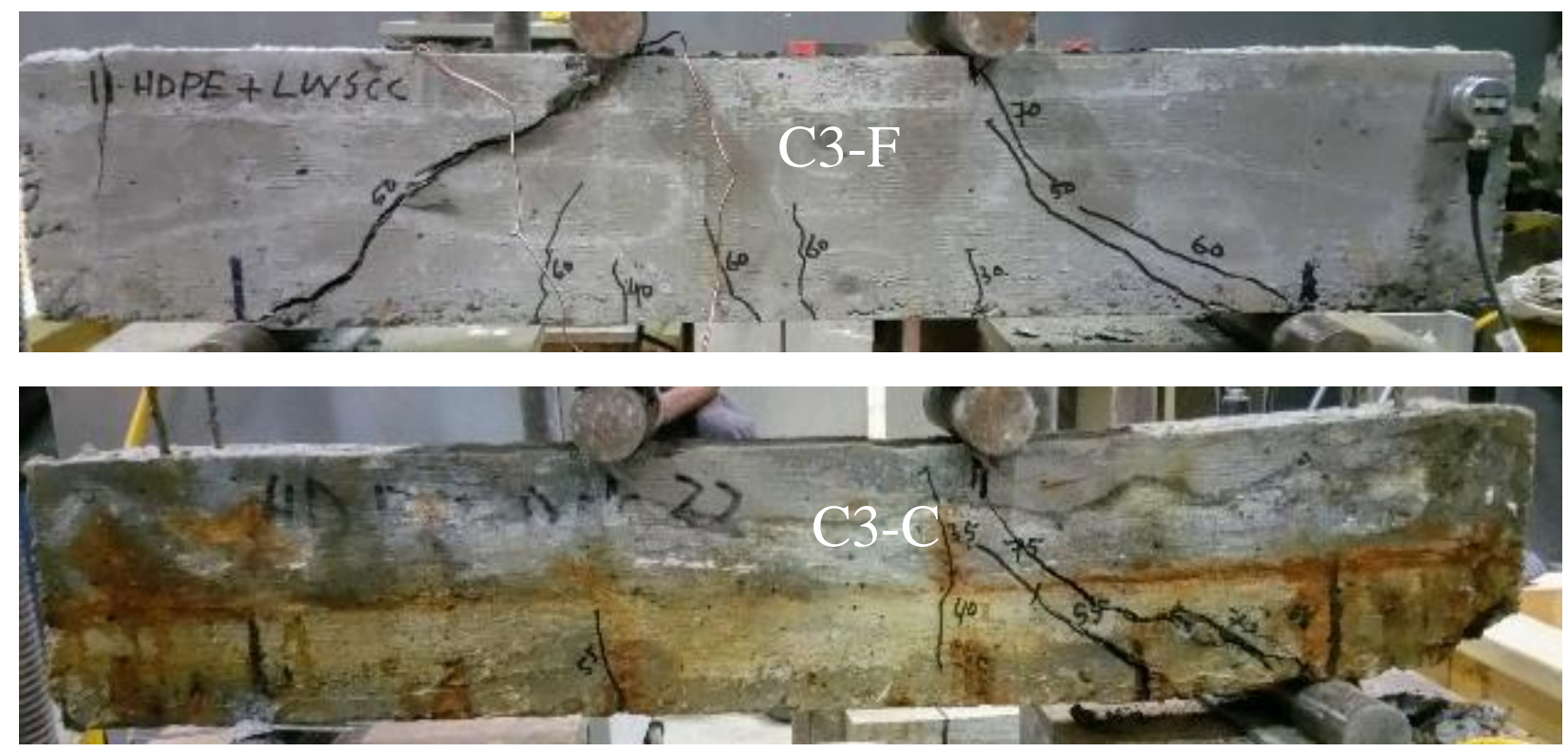

A- 11: Beams failure pattern after flexure and shear test of $\mathrm{C} 3-\mathrm{F}$ and $\mathrm{C} 3-\mathrm{C}$ 


\section{REFERENCES}

ACI 222 (2001). Protection of metals in concrete against corrosion, ACI 222R-01. American Concrete Institute, Farmington Hills, Michigan, 41p.

ACI 357 (1997). Building code requirements for reinforced concrete. American Concrete Institute, Farmington Hills, Michigan, 23p.

Ajdukiewicz, A., \& AKliszczewicz, A. (2002). Influence of recycled aggregates on mechanical properties of HS/HPC. Cement and Concrete Composite, 24 (2) 269-279.

Albano, C., Camacho, N., Reyes, J., Feliu, J., \& Hernandez, M. (2005). Influence of scrap rubber addition to portland I concrete composites: Destructive and nondestructive testing. Composite Structure, 71 (3-4), 439 - 446.

Ali, N., Amos, A., \& Roberts, M. (1993). Use of ground rubber tires in portland cement concrete. In: Proceedings of international conference on concrete 2000. University of Dundee, Dundee, Scotland, 379-390.

Andrade, C., Alonso, C., \& Molina, F. J. (1993). Cover cracking as a function of bar corrosion: Part I-Experimental test. Materials and structures, 26(8), 453-464.

ASTM C1202-12 (2012). Standard test method for electrical indication of concrete's ability to resist chloride ion penetration. American Society for Testing and Materials, West Conshohocken, PA, USA.

ASTM C330 (2014). Standard specification for lightweight aggregates for structural concrete. American Society for Testing and Materials, West Conshohocken, PA, USA.

ASTM C39 (2008). Standard test method for compressive strength of cylindrical concrete specimens1. American Society for Testing and Materials, West Conshohocken, PA, USA.

ASTM C494-16 (2016). Standard specification for chemical admixtures for concrete. American Society for Testing and Materials, West Conshohocken, PA, USA.

ASTM C78-16 (2013). Standard test method for flexural strength of concrete (using simple beam with third-point loading). American Society for Testing and Materials, West Conshohocken, PA, USA.

ASTM C876 (2016). Standard test method for corrosion potentials of uncoated reinforcing steel in concrete. American Society for Testing and Materials, West Conshohocken, PA, USA. 
ASTM D7250 (2016). Standard practice for determining sandwich beam flexural and shear stiffness. American Society for Testing and Materials, West Conshohocken, PA, USA.

ASTM E8/E8M (2016). Standard test methods for tension testing of metallic materials. American Society for Testing and Materials, West Conshohocken, PA, USA.

ASTM G1-03 (2011). Standard practice for preparing, cleaning, and evaluating corrosion test specimens.American Society for Testing and Materials, West Conshohocken, PA, USA.

Bamforth, P. (1987). The properties of high strength lightweight concrete. Cement and Concrete Research, 21(4), 8-9.

Behnam, V., \& Shami, N. (2016). Mix design of light-weight self-compacting concrete. Case Studies in Construction Materials, 4(June), 1-14.

Bertolini, L., Elsener, B., Pedeferri, P., Redaelli, E., \& Polder, R. B. (2004). Corrosion of steel in concrete: Prevention, Diagnosis, Repair (2nd Edition). Weinheim, Germany: Wiley-VCH, 434p.

Bhavi, B., Reddy, V., \& Ullagaddi, P. (2012). Effect of different percentages of waste high density polyethylene (HDPE) fibres on the properties of fibre reinforced concrete. Nature Environment and Pollution Technology 11(3), 461-468.

Bignozzi, M., \& Sandrolini, F. (2006). Tyre rubber waste recycling in self-compacting concrete. Cement and Concrete Research 36 (4), 735-739.

Bog, A. R., \& Topçu, I. B. (2012). Influence of fly ash on corrosion resistance and chloride ion permeability of concrete. Construction and Building Materials, 31(June), 258-264.

Broomfield, J. P. (2002). Corrosion of steel in concrete: understanding, investigation and repair, ( ${ }^{\text {nd }}$ Edition). Boca Raton, Florida, USA: CRC Press, 296p.

Celasun, I. N. (2016). Fresh, mechanical and durability properties of lightweight fiber reinforced concrete. Master's Project, Deptpertment of Civil Engineering, Ryerson University, Toronto, Canada, 92p.

Cor-map II. (2012). C-CM-5000-CU Cor-Map II operator's manual, Chicago, USA: James Instruments Inc.

Cornet, I., Ishikawa, T., \& Bresler, B. (1968). The mechanism of steel corrosion in concrete structure. Material Protection, 7 (3): 44-7.

CS. (2016). The Concrete Socity. Retrieved from www.concrete.org.uk: (Accessed March 5, 2017) http://www.concrete.org.uk/fingertips-nuggets.asp?cmd=display\&id=849 
Daczko, J. A. (2012). Self-consolidating concrete : Applying what we know. Boca Raton, Florida, USA: CRC Press, 292p.

Dua, Y., Cullen, M., \& Li, C. (2013). Structural performance of rc beams under simultaneous loading and reinforcement corrosion. Construction and Building Materials, 38 (Jan) 472481.

Dymond, B. Z. (2007). Shear strength of a PCBT-53 girder fabricated with lightweight selfconsolidating concrete. MASc Thesis, Virginia Tech, Blacksburg, USA.

EFNARC. (2005). The European guidelines for self compacting concrete. Surrey GU9 7EN, UK :www.efnarc.org.

Eldin, N., \& Senouci, A. (1993). Rubber-Tire particles as concrete aggregate. Journal of Materials in Civil Engineering, 5 (4), 478-496.

Gowripalan, N., \& Mohamed, H. (1998). Chloride-ion induced corrosion of galvanized and ordinary steel reinforcement in high-performance concrete. Cement and Concrete Research, 28, ( 8) 1119-1131.

Gu, G. P., Beaudoin, J. J., \& Vangi S., R. (2001). Techniques for corrosion investigation in reinforced concrete. Handbook of Analytical Techniques in Concrete Science and Technology. Noyes Publications, New Jersey, USA: 441-504.

Harding, M. A. (1995). Structural lightweight concrete- using structural lightweight concrete should pose few problems for knowledgeable contractors. Concrete construction. July, 4p.

Hariche, L., Ballim, Y., Bouhicha, M., \& Kenai, S. (2012). Effects of reinforcement configuration and sustained load on the behaviour of reinforced concrete beams affected by reinforcing steel corrosion. Cement \& Concrete Composites, 34(Nov), 1202-1209.

Hasib, M. S. (2016). Shear and flexure behavior of hybrid composite beams with high performance concretes. MASc thesis, Department of Civil Engineering, Ryerson University, Toronto, Canada, 141p.

Hasib, M. S., \& Hossain, M. K.A. (2016). Shear resistance of composite beams without shear reinforcement. Proc. 5th Int. Structural Specialty Conference, CSCE, London, Canada, June $1-4$.

Hassan, A. A. A., Hossain, K. M.A., \& Lachemi, M. (2012). Effect of metakaolin and silica fume on the durability of self-consolidating concrete. Cement \& Concrete Composites, 34(6) 801-807. 
Hassan, A.A.A., Hossain, K.M.A., \& Lachemi, M. (2008). Corrosion resistance of selfconsolidating concrete in full-scale reinforced beams. Cement \& Concrete Composites 31(1), 29-38.

Hassan, A.A.A., Hossain, K.M.A, \& Lachemi, M. (2009). Bond strength of deformed bars in large reinforced concrete members cast with industrial self-consolidating concrete mixture. Construction and Building Materials, 24 (4), 520-530.

Hassan, A.A.A., Hossain, K.M.A, \& Lachemi, M. (2010). Structural assessment of corroded selfconsolidating concrete beams. Engineering Structures, 32,(3), 874-885.

Hassan, A.A.A., Hossan, K.M.A., \& Lachemi, M. (2008). Behavior of full-scale self-consolidating concrete beams in shear. Cement \& Concrete Composites, 30(7), 588-596.

Higgins, C., Farrow III, W. C., Potisuk, T., Miller, T. H., Yim, S. C., Holcomb, G. R., Matthes, S. A. (2003). Shear capacity assessment of corrosiondamaged reinforced concrete beams. Department of Civil Engineering, Oregon State University, Corvallis OR 97331 and U. S. Department of Energy, Albany Research Center, Albany OR 97321, Corvallis, USA, 92p.

Hossain, K.M.A. (2004). Chloride induced corrosion of reinforcement in volcanic ash and pumice based blended concrete. Cement and Concrete Composites, 27 (3), 381-390.

Hossain, K.M.A (2004a). Properties of volcanic pumice based cement and lightweight concrete. Cement and Concrete Research, 34(2) 283-291.

Hossain, K.M.A. (2004b). Properties of volcanic scoria based lightweight concrete. Magazine of Concrete Research, 56(2) 111-120.

Hossain, K. M. A. (2005). Chloride induced corrosion of reinforcement in volcanic ash and pumice based blended concrete. Cement and Concrete Composites, 27(3), 381-390.

Hossain, K. M. A. (2006). Blended cement and lightweight concrete using scoria: mix design, strength, durability and heat insulation characteristics. International Journal of Physical Sciences, 1(1), 005-016.

Hossain, K.M.A. (2015). Sustainable infrastructure development strategies through technological innovation of smart materials. Journal of Emerging Trends in Engineering and Applied Sciences (JETEAS), 6(7), 180-187.

Hossain, K.M.A., \& Anwar, M. (2014). Properties of green engineered cementitious composites incorporating volcanic materials. Procedure of structural faults repair, 8th - 10th July, Imperial College, London, UK. 
Hossain, K. M. A., \& Lachemi, M. (2006). Deterioration and corrosion in scoria based blended cement concrete subjected to mixed sulfate environment. International Journal of Physical Sciences, 1(4), 163-174.

Hossain, K.M.A., \& Lachemi, M. (2010). Fresh, mechanical, and durability characteristics of selfconsolidating concrete incorporating volcanic ash.ASCE,Journal of Materials in Civil Engineering, 22(7), 651-657.

Hossain, K.M.A., \& Lachemi, M. E. (2009). Evaluation of the effect of marine salts on urban built infrastructure. Building and Environment, 44(4), 713-722.

Hossain, K.M.A., Alam, S., Anwar, M., \& Julkarnine, K. (2016). High performance composite slabs with profiled steel deck and Engineered Cementitious Composite - Strength and shear bond characteristics. Construction and Building Materials, 125(Oct.), 227-240.

Hubertova, M., \& Hela, R. (2007). The effect of metakaolin and silica fume on the properties of lightweight self-consolidating concrete. American Concrete Institute, ACI, Detroit, USA SP-243, 35-48.

Hunkeler, F. (2005). Corrosion in reinforced concrete: processes and mechanisms, $1^{\text {st }}$ Edition. Florida, USA:Woodhead Publishing, 264p.

Hussain, R. R., Shuraim, A. B., \& Alhozaimy, A. M. (2015). Investigation for the impact of nature of coarse aggregate on the passive layer formation and corresponding corrosion of reinforcement bars in high performance concrete. Construction and Building Materials, 100(Dec.), 52-62.

Hussein, L., \& Amleh, L. (2015). Structural behavior of ultra-high performance fiber reinforced concrete-normal strength concrete or high strength concrete composite members. Construction and Building Materials, 93(Sep.), 1105-1116.

Ismail, M., \& Ohtsu, M. (2006). Corrosion rate of ordinary and high-performance concrete subjected to chloride attack by AC impedance spectroscopy. Construction and Building Materials, 20(7), 458-469.

Jaffer, S., \& Hansson, C. (2008). The influence of cracks on chloride-induced corrosion of steel in ordinary Portland cement and high performance concretes subjected to different loadingconditions. Corrosion Science, 50(12), 3343-3355.

JCI-DFRCC Committee. (2003). DFRCC terminology and application concepts. Journal of Advanced Concrete Technology, 1 (3), 335-340. 
Kaffetzakis, M., \& Papanicolaou, C. (2012). Mix proportioning method for lightweight aggregate SCC (LWASCC) based on the optimum packing point concept. Innovative Materials and Techniques in Concrete Construction. Springer, Dordrecht, Netherlands, (Feb.) 131-151.

Karahan, O., Hossain, K. M.A., Ozbay, E., Lachemi, M., \& Sancak, E. (2012). Effect of metakaolin content on the properties self-consolidating lightweight concrete. Construction and Building Materials, 31(Jun.), 320-325.

Karahan, O., Ozbay, E., Hossain, K. M.A., Lachemi, M., \& Atis, C. D. (2012). Fresh, Mechanical, Transport and Durability Properties of Self-Consolidation Rubberized Concrete. ACI Materials Journal, 109(4), 413-420.

Kayali, O., \& Zhu, B. (2005). Corrosion performance of medium-strength and silica fume highstrength reinforced concrete in a chloride solution. Cement \& Concrete Composites, 27(1), $117-124$.

Kobayashi, K., \& Cho, R. (1981). Flexural behaviour of polyethylene fibre reinforced concrete. International Journal of Cement Composites and Lightweight Concrete, 3 (1), 19-25.

Koch, G., Varney, J., Thompson, N., Moghissi, O., Gould, M., \& Payer, J. (2016). FInternation measures of prevention, application, and economics of corrosion technology. Houston: NACE International, Houston, Texas, USA, 216p

Koehler, E., \& Fowler, D. (2007). Aggregates in self-consolidating concrete. International Center for Aggregates Research (ICAR), The University of Texas, Austin, USA.

Lachemi, M., Hossain, K.M.A, Lambros, V., Lambrosa, P. C., \& Bouzouba, N. (2004). Selfconsolidating concrete incorporating new viscosity modifying admixtures. Cement and Concrete Research, 34(2), 917-926.

Lachemi, M., \& Hossain, K.M.A. (2010.). Properties of controlled low-strength materials incorporating cement kiln dust and slag. Cement \& Concrete Composites, 32(Jul.), 623629.

Lacombe, P., Beaupré, D., \& Pouliot, N. (1999). Rheology and bonding characteristics of selfleveling concrete as a repair material. Materials and Structures, 32(Oct.), 593-600.

Leung, C. K., Cheung, Y. N., \& Zhang, J. (2007). Fatigue enhancement of concrete beam with ECC layer. Cement and Concrete Research, 37 (5), 743-750.

Li, J., Chen, Z. Z., Xie, W. F., \& Liu, F. (2009). Experimental study of recycled rubber-filled highstrength concrete. Magazine of Concrete Research, 61(7), 549-556. 
Li, V. C. (1995). New construction materials proliferate in Japan. Civil Engineering, 65( 8), 3841.

Li, V. C. (1998). Engineered Cementitious Composites for Structural Applications. ASCE, Journal of Materials in Civil Engineering, 10(2), 66-69,.

Li, V. C. (2007). Engineered Cementitious Composites (ECC) - Material, Structural, and Durability Performance. University of Michigan, Ann Arbor, MI 48109, 10p.

Li, V. C., Horii, H., Kabele, P., Kanda, T., \& Lim, Y. (2000). Repair and retrot with engineered cementitious composites. Engineering Fracture Mechanics, 65(2), 317-334.

Li, V. C., Wang, S., Ogawa, A., \& Saito, T. (2002). Interface tailoring for strain-hardening PVAECC. ACI Materials Journal, 99,(5), 463-472.

Li, V.C., Fischer, G., Kim, Y., Lepech, M., Qian, S., Weimann, M., \& Wang, S. (2003). Durable link slabs for jointless bridge decks based on strain-hardening cementitious composites,. Report for Michigan Department of Transportation (No. of Research Report RC- 1438).

Lotfy, A. (2012). Lightweight self-consolidating concrete: statistical modelling, mixture design and performance evaluation, $\mathrm{PhD}$ Thesis, Department of Civil Engineering, Ryerson University, Toronto, Canada, 417p.

Lotfy, A., Hossain, K. M. A, \& Lachemi, M. (2015). Statistical models for the development of optimized furnace slag lightweight aggregate self-consolidating concrete. Cement \& Concrete Composites, 55(Jan.), 169-185.

Lotfy, A., Hossain, K. M. A., \& Lachemi, M. (2016a). Durability properties of lightweight selfconsolidating concrete developed with three types of aggregates. Construction and Building Materials, 106(Mar), 43-54.

Lotfy, A., Hossain, K.M.A, \& Lachemi, M. (2016b). Mix design and properties of lightweight self-consolidating concretes developed with furnace slag, expanded clay and expanded shale aggregates. Journal Sustainable Cement based Materials, 5(5), 297-323.

Mangum, L. (2006). The Concrete Countertop Institute (CCI). Retrieved from http://www.concretecountertopinstitute.com, (Acceessed July 5, 2017) http://www.concretecountertopinstitute.com/?s=Lightweight+Concrete+Mixes

Mishra, D. K. (1995). Design of pseudo strain-hardening cementitious composites for a ductile plastic hinge. PhD Thesis, University of Michigan, Ann Arbor, USA. 
Montes, P., Bremner, T. W., \& Lister, D. H. (2004). Influence of calcium nitrite inhibitor and crack width on corrosion of steel in high performance concrete subjected to a simulated marine environment. Cement \& Concrete Composites, 26 (3) 243-253.

Neville, A. (1997). Properties of Concrete, 4th Edition, New York, USA: John Wiley \& Sons

Neville, A., \& Aitcin, P.C. (1998). High performance concrete- An overview. Materials and Structures, 31(2), 111-117

Okamura, H., \& Ozawa, K. (1994). Self-Compactable High-Performance Concrete in Japan. American Concrete Institute, Farmington Hills, MI, USA, 31-44.

Ozawa, K., Maekawa, K., Kunishima, H., \& Okamura, H. (1889). Performance of concrete based on the durabiity design of concrete structures. Proce. The second East-Asia-Pacific Conference on Structural Engineeing and Construction, 1(Aug.), 445-456.

Ozyildirim, C. (2014). Lightweight high-performance concrete Bulb-T beams with selfconsolidating concrete in a bridge structure.Virginia Center for Transportation Innovation and Research, Virginia, USA, 26p.

PCA. (2002). Types and Causes of Concrete Deterioration. Portland Cement Association, Skokie, Illinois, USA, pp. 16. (Accessed May 15, 2017) Retrieved from www.cement.org: http://www.cement.org/learn/concrete-technology/durability/corrosion-of-embeddedmaterials

Peackock, A. (2000). Handbook of Polyethylene: Structures, Properties and Applications (Plastics Engineering). Boca Raton, Florida, USA: CRC Press, 544p.

Pelisser, F., Zavarise, N., Longo, T. A., \& Bernardin, A. M. (2011). Concrete made with recycled tire rubber: effect of alkaline activation and silica fume addition. Journal of Cleaner Production, 19(6), 757-763.

Pešic', N., Zivanovic, S., Garcia, R., \& Papastergiou, P. (2016). Mechanical properties of concrete reinforced with recycled HDPE plastic fibres. Construction and Building Materials, 15 (2016) 362-370.

Rodriguez, J., Ortega, L., \& Castel, J. (1994). Corrosion of reinforcing bars and service life of reinforcing concrete structure: Corrosion and bon deterioration. In International conference on concrete across borders, Odense, Denmark, 2(July), 315-26. 
Salahuddin, Q., \& Maalej, M. (2014). Application of Engineered Cementitious Composites (ECC) in interior beam-column connections for enhanced seismic resistance. Engineering Structures, 69(June), 235-245.

Seddik, A., Beroual, A., Zergua, A., \& Guetteche, M. N. (2013). Self Compacting Concrete under Local Conditions. Open Journal of Civil Engineering, 3(02),119p.

Shanmugam, S., Srisanthi, V., \& Ramachandran, S. (2013). Effects of Corrosion on Reinforced Concrete Beams with Silica Fume and Polypropylene Fibre. International Journal of Civil, Environmental, Structural, Construction and Architectural Engineering 7(2), 151-156.

Sherir, M. A. (2012). Fracture Energy, Fatigue and Creep Properties of Engineered Cementitious Composites Incorporating Fly Ash/Slag with Different Aggregates. MASc Thesis, Depertment of Civil Engineering, Ryerson University, Totonto, Canada,134p.

Sherir, M., Hossain, K.M.A., \& Lachemi, M. (2016). Self-healing and expansion characteristics of cementitious composites with high volume fly Ash and MgO-type expansive agent. Construction \& Building Materials, 127(Nov.), 80-92.

Sherir, M., Hossain, K.M.A., \& Lachemi, M. (2017). Development and recovery of mechanical properties of self-healing cementitious composites with $\mathrm{MgO}$ expansive agent. Construction and Building Materials, 148(Sep.), 789-810.

Siad, H., Alyousif, A., Keskin, O., Kasap, K., Suleyman, B., Lachemi, M., \& Hossain, K.M.A. (2015). Influence of limestone powder on mechanical, physical and self-healing behavior of Engineered Cementitious Composites. Construction and Building Materials, 99(Npv.),1-10.

Siad, H., Lachemi, M., Bernard, S. K., Sahmaran, M., \& Hossain, K.M.A. (2015). Assessment of the long-term performance of SCC incorporating different mineral admixtures in a magnesium sulphate environment. Construction and Building Materials, 80(Apr.), 141154.

Siad, H., Lachemi, M., Sahmaran, M., \& Hossain, K.M.A. (2017). Mechanical, Physical, and Self-Healing Behaviors of Engineered Cementitious Composites with Glass Powder.ASCE, Journal of Materials in Civil Engineering, 29(6). http://dx.doi.org/10.1061/(ASCE)MT.1943-5533.0001864.

Sideris, K., \& Savva, A. (2005). Durability of mixtures containing calcium nitrite based corrosion inhibitor. Cement \& Concrete Composites, 27(2), 277-287. 
Soroushian, P., Khan, A., \& Hsu, J.-W. (1992 ). Mechanical properties of concrete materials reinforced with polypropylene or polyethlene fibres. ACI Material Jaournal, 89 (6) (1992) $535-540$.

Spainhour, L. K., \& Wootton, I. A. (2008). Corrosion process and abatement in reinforced concrete wrapped by fiber reinforced polymer. Cement \& Concrete Composites, 30(6), 535-543.

Su, H., Yang, J., Ling, T., Ghataora, G., \& Dirar, S. (2015). Properties of concrete prepared with waste tyre rubber particles of uniform and varying sizes. Journal of Cleaner Production, 91(Mar.), 288-296.

Wang, L., Li, C., \& Yi, J. (2015). An Experiment Study on Behavior of Corrosion RC Different Concrete Different Concrete Strenght. Journal of Coastal Research 73.sp1(Mar.), 259-264.

Wang, L., Zhang, X., Zhang, J., Ma, Y., \& Liu, Y. (2015). Effects of stirrup and inclined bar corrosion on shear behavior of RC beams. Construction and Building Materials, 98(NOv.), 537-546.

Wang, X.-H., Li, B., Gao, X.-H., \& Liu, X.-L. (2011). Shear behaviour of RC beams with corrosion damaged partial length. Materials and Structures 45(3),351-379.

Yeganeh, A. E. (2015). Structural behaviour of reinforced high performance concrete frames subjected to monotonic lateral loading. MASc Thesis, Depertment of Civil Engineering, Ryerson University, Totonto, Canada,108p.

Yin, S., Tuladhar, R., Shi, F., Combe, M., Collister, T., \& Sivakugan, N. (2015). Use of macro plastic fibres in concrete: a review. Constron and Building Materials, 93(Sep.),180-188.

Yu, L., François, R., Dang, V. H., L'Hostis, V., \& Gagné, R. (2015). Development of chlorideinduced corrosion in pre-cracked RC beams under sustained loading: Effect of loadinduced cracks, concrete cover, and exposure conditions. Cement and Concrete Research, 67(Jan.),246-258.

Zain, M. F., Islam, M. N., \& Basri, I. H. (2005). An expert system for mix design of high performance concrete. Advances in Engineering Software, 36(5), 325-337.

Zhang, J., Wang, Z., Ju, X., \& Shi, Z. (2014). Simulation of flexural performance of layered ECCconcrete composite beam with fracture mechanics model. Engineering Fracture Mechanics, 131(Nov.), 419-438. 
Zhang, R., Matsumoto, K., T. H., Y. I., \& Niwa, J. (2015). Application of PP-ECC in beamcolumn joint connections of rigid-framed railway bridges to reduce transverse reinforcements. Engineering Structures 86(Mar.), 146-156.

Zhu, W., François, R., Coronelli, D., \& Cleland, D. (2013). Effect of corrosion of reinforcement on the mechanical behaviour of highly corroded RC beams. Engineering Structures, 56(Nov.), 544-554. 